Historic, Archive Document

Do not assume content reflects current scientific knowledge, policies, or practices. 




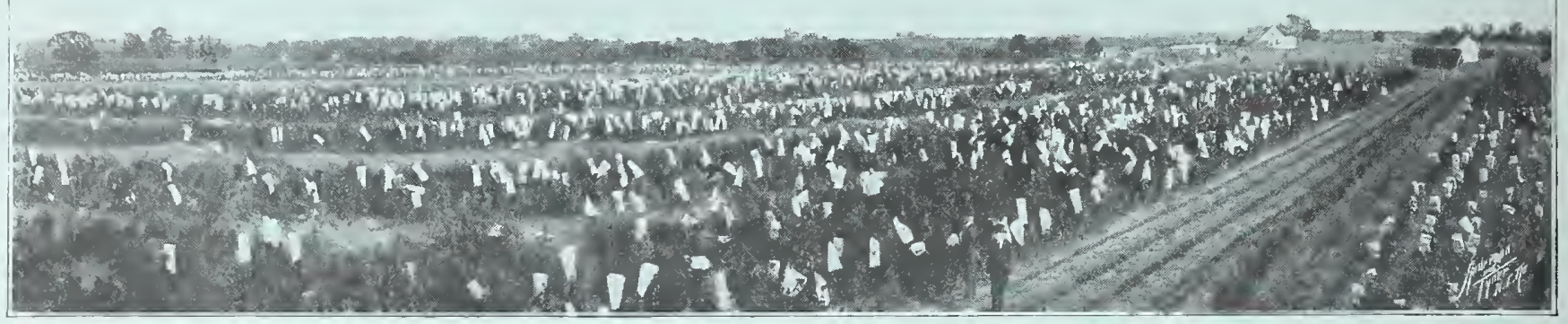

Partial View of Our Celosia Compacta Chrysantheflora Seed-Cultures at Our 39th and Blue Ridge Flower Farm

\section{FORWORD}

To those not familiar with the Bryson Ayres service, it is important to know that our Seed Farms, Nurseries and modern warehouses are located just a few miles from our retail store.

All operations of the Company are under the personal supervision of Bryson Ayres, who is nationally known as one of the most successful plant breeders. Our years of experience and our constant efforts to improve our service have given us an organization second to none. We attribute our remarkable growth to our service and to the great care taken in the growing, selecting and testing of all seeds.

Over one hundred acres are devoted to Hardy Perennial Plants, Roses, Ornamental Shrubs and Fruits, and during the summer months the sight is a beautiful one. Then too, there are fields of blossoming Red Clover, Sweet Clover, Alfalfa, Alsike, and other grasses, making the farm a source of wonder and delight.

We want you to see and know our farms and nurseries, with their flowers and high quality seeds-visitors are always welcome, and an intelligent guide will be furnished gladly. A most cordial invitation to visit us is extended to all.

Sincerely yours,

\section{THE BRYSON AYRES SEED COMPANY}

General Offices and Retail Store

503 Walnut St., Kansas City, Mo.

Farm No. I, Independence, Mo.

Farm No, 2, 39th and Blue Ridge Blvd., Kansas City, Mo.

\section{IMPORTANT AnMOUNCEMENT-CUT FLOWERS.}

For more than fifteen years BRYSON AYRES has been at the top of the profession as a grower of cut flowers. But, heretofore, his products have been sold in Kansas City and surrounding territory through recail florists only.

We now, for the first time, offer direct to our customers, the choicest blooms from our Nurseries and Greenhouses at a great saving. Orders placed with us will be executed with the very best care and attention.

You can leave your orders at our seed store, 503 Walnut street, or come to our Nurseries and Flower farms at 39th and Blue Ridge Boulevard, or to the Greenhouses at Independence, Missouri. Everyone welcome. 


\title{
THE \\ BRYSON AYRES \\ GARDEN BOOK \\ for 1922
}

\author{
503 WALNUT STREET
}

KANSAS CITY, MO.

\section{OUR GUARANTEE}

Any customer sendlng cash wlth order for Seeds has the privliege of returning them within flfteen days after recelpt of same. Is he is not satisfied, and the money paid for same wlil be returned. This applles to Garden, Flower or Farm Seeds.

WIIT WE (iUARANTEE: Tbat ail money sent to us for seeds shail reach us if sent by reglstered letter, postoffice or expross money order, or bank draft made payable to our order. That your order will be filled promptiy and weil. That goods ordered will reach you safely. Keep a copy of your order. Sometimes persons think they have ordered artlcies which they have omitted, and think they have ordered artlcies

IIOW TO ORDER. - In making out your order, write Name, Postoffice, County and state, and the varleties you want. quantitles of eacn, and carry out the catalogue price after each one, enclosing total amount, In any convenient form of remittance, to us by mali. Use nur Order Biank if you liave it.

MAIL OR EXIRFSS. - We send seed postpald by mall at the prices named in this Catalogue, except where there are speclat quoprices named in this catalogue, except where there are speclai quotations to be sent by express, customers to pay the charges. To
points where the Express Companies touch, we can send some orders as cheaply by express as by mali.

FXPRESS OR FREICIIT.-We do not prepay exprens or frelght, except in case we have quite an order purchased at postpald prices and may prefer to send by express. prepald.

TERMS AND C. O. D. SHIPIENTS,-Our terms are strictly cash with the order. We must decilne to ship goods C. O. D.

ABOUT WARIANTING.-We thoroughly test our seeds and nothing is sent out whlch we do not belleve to be good in every respect. When lt is consldered how many are the contlngencles on whlch the success of any crop deprends, such as sowing too deep or too shallow, too wet or Ary soll, unfavorable weather, insects, etc, our customers wlll readily see that il would be sheer folly for anyone to warrant seeds to produce a perfect crop, and we want it piainly understood that, while we exerclse great care to have sil Seeds pure and reliable, and also true to name. we do not give any warranty, express or implied, as to deseription, quality, productiveness, or any other matter of any Seeds, Builis, or Plants we gend out, and we will not be in any way responsible for the crop. If the purchaser does not accept the Seeds on these terms and conditions, they aro to be returned at once, and the money that has bcen paid for same wlli be refunded. No offlcer, agent or empioye bcen However, we have so much confidence in our Serals that we hereby However, we have so much confidence In our Serds that we hereby
agree to refill any retail order for Vegetable or Flower Seeds free of charge should they prove otherwise than as we represent them. We know of no responsible seed Firm in the world whlch guarantees Seeds any further than this. Compare with other Seed Cataiogus: and you will see that we are right.

MARKET GARDENERS and others who buy Vegetable Seerls In bulk to the amount of $\$ 5.10$ or more are requested to send their Ilst of Seeds wanted to us and let us make special quotatlons.

PI.ANT ORDERS.--Orders for Plants will be filled as early in the spring as we conslder it safe to send them. If ordered for immedlate shipment in severe weather, they will be sent at purchaser's risk.

HOV TO SEND MONEY.-Elther Postoffice Money Order, Express Money Order, Bank Draft, or Reglstered Letter. Smail amounts. will be accepted in postage stamps. Coln should bs gewed or pasted in cloth or pasteboard to prevent breaking through the envelope, and registered. Do not send money loose in a letter: it is not safe, and if lost, we are not responsible for it.

\section{Parcel Post.}

Rates of postage on fourth class or parcel post mat. ter, to be fully prepaid, unsealed, are as follows:

(A) Parcels weighing 4 ounces or less, except books, seeds, plants, etc., 1 cent for each ounce or fraction thereof, any distance.

(B) Parcels weighing 8 ounces or less, containing books, seeds, cuttings, bulbs, roots, scions and plants, 1 cent for each 2 ounces or fraction thereof, regardless of distance.

(C) Parcels weighing more than 8 ounces containing books, seeds, plants, etc., parcels of miscellaneous printed matter weighing more than 4 ounces, and all other fourth class matter weighing more than 4 ounces, are chargeable, according to distance or zone, at the pound rates shown in the following table, a fraction of a pound being considered a full pound.

Parcel post mail requiring 25c or more of postage (not counting insurance fee) will require a war tax of $1 \mathrm{c}$ for each $25 \mathrm{c}$ or fraction thereof. On parcels less than $25 \mathrm{c}$ no tas is required.
RATES.

Lbs.

$\begin{array}{lrrrrrrr}1 & \$ 0.05 & \$ 0.05 & \$ 0.05 & \$ 0.06 & \$ 0.07 & \$ 0.08 & \$ 0.09 \\ 2 & .06 & .06 & .06 & .08 & .11 & .14 & .17 \\ 3 & .06 & .07 & .07 & .10 & .15 & .20 & .25 \\ 4 & .07 & .08 & .08 & .12 & .19 & .26 & .33 \\ 5 & .07 & .09 & .09 & .14 & .23 & .32 & .41 \\ 6 & .08 & .10 & .10 & .16 & .27 & .38 & .49 \\ 7 & .08 & .11 & .11 & .18 & .31 & .44 & .57 \\ 8 & .09 & .12 & .12 & .20 & .35 & .50 & .65 \\ 9 & .09 & .13 & .13 & .22 & .39 & .56 & .73 \\ 10 & .10 & .14 & .14 & .24 & .43 & .62 & .81 \\ 11 & .10 & .15 & .15 & .26 & .47 & .68 & .89 \\ 12 & .11 & .16 & .16 & .28 & .51 & .74 & .97 \\ 13 & .11 & .17 & .17 & .30 & .55 & .80 & 1.05 \\ 14 & .12 & .18 & .18 & .32 & .59 & .86 & 1.13 \\ 15 & .12 & .19 & .19 & .34 & .63 & .92 & 1.21 \\ 16 & .13 & .20 & .20 & .36 & .67 & .98 & 1.29 \\ 17 & .13 & .21 & .21 & .38 & .71 & 1.04 & 1.37 \\ 18 & .14 & .22 & .22 & .40 & .75 & 1.10 & 1.45 \\ 19 & .14 & .23 & .23 & .42 & .79 & 1.16 & 1.50 \\ 20 & .15 & .24 & .24 & .44 & .83 & 1.22 & 1.61 \\ & & & & & & & \end{array}$

Remember, we pay postage on all light Garden Seed. When ordering Beans, Peas, Sweet Corn, and Onion Sets In connection with other Seeds, add one cent per pound for postage. When heavier Seeds are ordered alone, add five cents for first pound and one cent for each pound above that. 


\section{BRYSON AYRES Reliable Vegetable Seeds ASPARAGUS \\ DWARF OR BUSH BEANS \\ Best Green-Podded Sorts.} acre.

If rows be 6 feet apart, 5,000 plants are required per

Culture--Asparagus is one of the first vegetables in spring, as well as one of the best grown in the garden. It is perfectly hardy. grows year after year from the same roots, and never fails to pro duce a crop. Asparagus does well on any well-dralned soll, but the best results are obtained from rich, deep, loamy soil. Asparagus is easily grown from seed. One ounce will plant about 50 feet of row and furnish about 400 plants. The seed should be planted as sarly in the spring as the weather becomes settled. Considerable crop may be expected the third year from seed, but it is best to bus bwoyear-old plants.

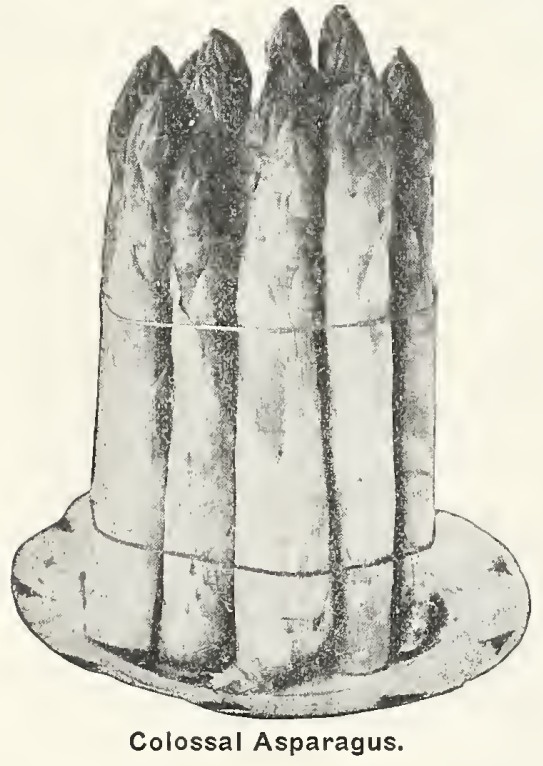

CONOVER'S COLOSSAL.-A well-known standard variety, very large, strong shoots of excellent quality; not as clear white as Mammoth White, but preferred by many. Seed, price, prepaid, oz., 10c; 1/4 lb., 25c; 1 lb., 75c; 5 lbs., $\$ 3.00$. Roots, prepaid, per $100, \$ 1.50$.

PALMETTO.-A very early maturing and prolific variety, producing an abundance of very large, deep green shoots of the best quality. See price prepaid, oz., 10c; $1 / 4$ Ib., 25c; 1 lb., 75c; 5 lbs., $\$ 3.00$. Roots, price prepaid, per $100, \$ 1.50$.

Our strong two-year-old roots will give the best results; bear some first year. Doz., 40c, postpaid.

\section{BEANS}

Mature for table 30 to 50 days from germinationaccording to variety. Two bushels to the acre in drills Order early.

Culture.-When all danger of spring frosts is over is the time to plant Beans. They thrive little when the soll, the days and nights are cold. Given moisture, this crop can be planted in suc cession until the middle of August: Sandy loam is the best soll, but they grow well in any soll of average richness.

Bush varleties should be planted $1 \frac{1 / 2}{2}$ inches deep in drills 18 inches or 2 feet apart, 2 inches apart in the drill. Pole varietles should be planted two or three beans in a hill, 3 feet apart each way. When plants are well up, thin gradually to 6 or 8 inches from each other, leaving the strongest plants as much as possible. Give them clean cultivation, mellowing the soil about them, but not going too deep, hilling broad and flat about the time they are to bear. Do not hoe when wet from dew or raln, as this induces rust of leaves or pods. A quart will plant 100 feet of drill; 2 bushels to the acre in drills.

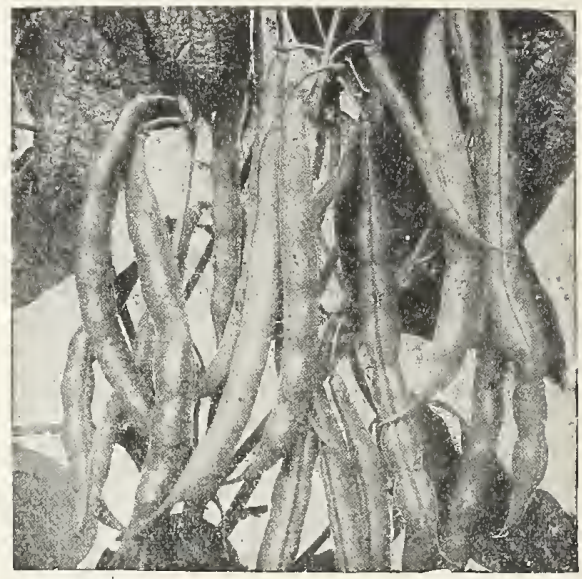

Stringless Green Pod.

BOUNTIFUL.-(31 days.) A prolific and continuous bearer. The first in spring, the last in fall. Absolutely stringless; very tender and of delicious flavor. This is a green-pod Bean and the pods are absolutely stringless, long, more or less curved, deeply creased back, sharply constricted between seeds, dark green, extremely brittle, and totally without fibre. The plant is large and very erect when young, but becomes weighted down when fully developed. Because of its absolutely stringless, brittle, fiberless green pods, is one of the most popular varieties. Pkt., $10 \mathrm{c} ; 1$ lb., 35c; 10 Ibs., \$2,50, postpaid.

BURPEE'S STRINGLESS GREEN-POD.-(33 days.) The pods are absolutely stringless, full, fleshy, crisp, very tender and of the finest flavor, remaining long in edible condition. Ready for the market two days earlier than Valentine and very prolific. Pkt., 10c; 1 lb., 35c; 10 lbs., $\$ 3.00$, postpaid.

GIANT STRINGLESS GREEN POD BEAN.-This is a great improvement on the old-time popular favorite Valentine Bean. The pods are fully one-third longer, averaging 5 and 6 inches in length; absolutely stringless, very crisp, round, full and fleshy. It is enormously productive, its handsome pods being ready for market a few days earlier than the old Valentine. Pkt., 10c; Ib., 35c, postpaid; 10 lbs., $\$ 2.50$, postpaid.

EXTRA EARLY RED VALENTINE-(35 days.) Best improved round pod strain. Pkt., 10c; 1 lb., 35c; $10 \mathrm{lbs}$., $\$ 2.75$, postpaid

LONG YELLOW SIX WEEKS.-In many sections a popular market sort. When young, pods are of good quality. Very productive and hardy. Pods are long, straight and quite thick. Pkt., 10c; 1 lb., 35c; 10 lbs., \$2.50, postpaid.

BLACK VALENTINE.-A great improvement over the popular Red Valentine, the pods being perfectly round and straight, though not quite so early. It will withstand early and late frosts. Owing to its enormous yielding qualities and handsome appearance, it is a desirable sort for the market gardener. Pkt., 10c; 1 lb., 35c; $10 \mathrm{lbs}$, $\$ 2.50$, postpaid. 


\section{Beans, Dwarf or Bush-Cont. BEST YELLOW-PODDED SORTS}

IMPROVED GOLDEN WAX.-(32 days.) Very early, pods are large, about 5 inches long, a golden wax color, very tender and brittle. Pkt., 10c; 1 lb., 35c; 10 lbs., \$2.75, postpaid.

PROLIFIC BLACK WAX.-(33 days.) The pods are yellow, very tender, 4 to 5 inches long, transparent, and stringless. Pkt., 10c; 1 lb., 35c; 10 lbs., \$2.75, postpaid.

WARDWELL'S KIDNEY WAX.-(35 days.) This variety, maturing a little later than the Golden Wax, yields a large crop of long, nearly straight, broad, light golden yellow, handsome pods. These are of large size, about 6 inches long, and of good quality. They always command a ready sale, making the variety one of the most profitable for the market gardener. Suitable also for snaps for home garden use. The leaves are large and slightly roughened. Seed large, flattened, kidney-shaped, white, with dark markings about the eye. Pkt., 10c; 1 lb., 35c; 10 Ibs., $\$ 2.75$, postpaid.

GOLDEN EYE WAX.-Very productive; long, nearly straight; golden yellow pods; large size, fine quality; one of the best for market gardeners. Pkt., 10c; $1 \mathrm{lb}$, 35 c; 10 lbs., $\$ 2.75$, postpaid.

DAVIS' WHITE WAX.-(40 days.) Very productive bearing large handsome pods, straight, 6 inches long. Pkt., $10 \mathrm{c}$; 1 lb., 35c; 10 lbs., $\$ 2.75$, postpaid.

CURRIE'S RUST-PROOF WAX.-Seed black; a very tine sort. Rust-proof, tender, thick-fleshed pods; early and very productive. Pkt., 10c; 1 lb., 35c; 10 lbs., $\$ 2.75$, postpaid.

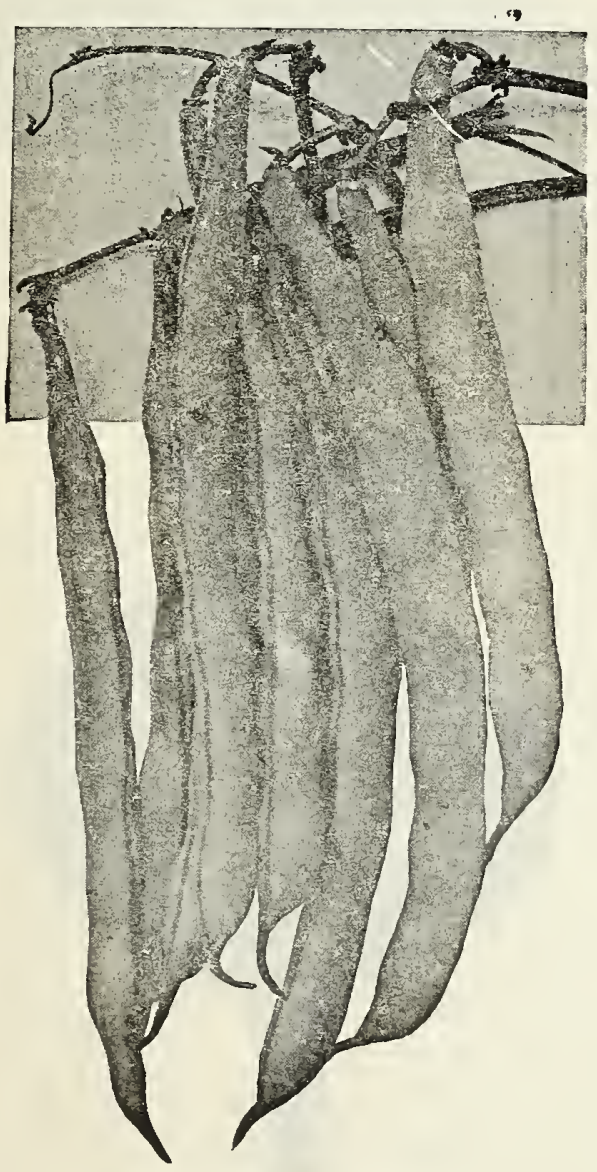

Improved Golden Wax.

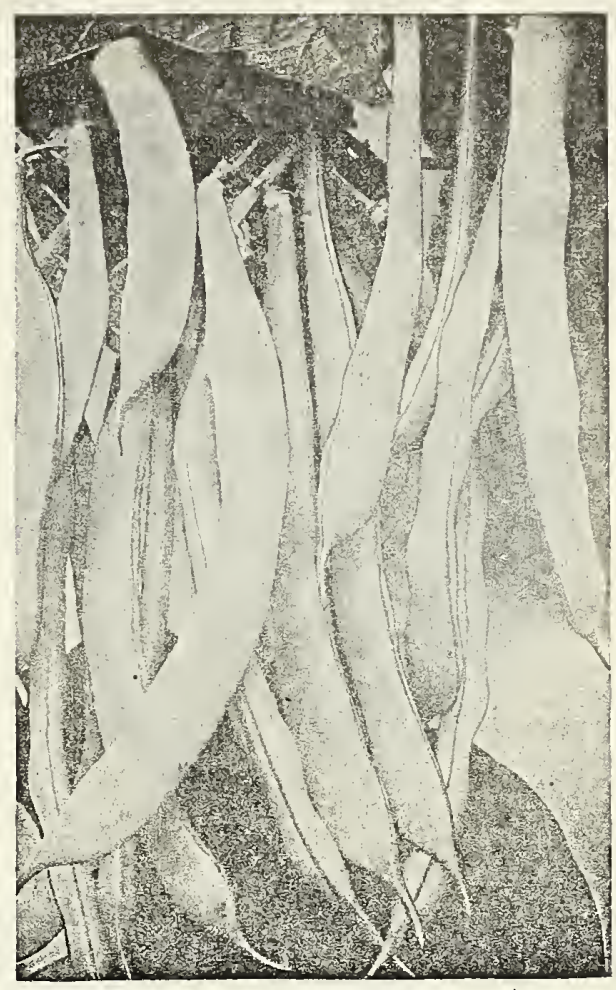

Davis' White Wax.

\section{Beans, Pole, Lima and Field Beans POLE BEANS}

KENTUCKY WONDER.-Als'o known as Old Home. stead. We believe this variety is the most practically useful of the green-podded Pole 'Beans, suitable for use as snaps. It is an early, very prolific sert, with showy pods of most excellent quality. The vines are vigorous, climbing well and very productive, searing pods in large clusters. The pods are medium light greeu, very long, often reaching 9 to 10 inches, curved and twisted, nearly round and very crisp when young, becoming very irregular and spongy as the Beans ripen. One of the very best early Pope Snap Beans for the home garden or market. Pkt., 10c; 1 lb. $35 c ; 2$ lbs., 65c, postpaiả.

KENTUCKY WONDER WAX.-A yellow-podded "Kentucky Wonder," which bears a large quantity of rich, golden-yellow pods from the time the plant is about half grown until it is killed by frost in the fall. By express or freight, at purchaser's expense, pkt., 10c; 1 lb., 35c; 5 lbs., $\$ 1.50$, postpaid.

CUT SHORT OR CORNFIELD.-Green-podded Snap Pole Bean. A marvel of productiveness from July until frost. Large, thick, stringless pods, meaty, tender and delicious; pods green, round and long. Resembles the Kentucky Wonder, but has many superior qualities. 1t is larger and more prolific. Bears when scarcely higher than the average bush variety and produces continuously until frost. Absolutely stringless. Pkt., 10c; Ib., 35c; 10 lbs., $\$ 3.00$; postpaid.

LAZY WIFE.-Pods are wonderfully broad and fleshy, and, above all, stringless. In many respects, they surpass anything we know of. Then again. the pods retain their stringless and tender qualities until they are almost ripe. Pkt., 10c; $1 \mathrm{lb} ., 35 \mathrm{c}$; 10 lbs., $\$ 3.00$, postpaid. 


\section{THE BRYSON AYRES SEED CO.}

\section{Beans, Pole Beans-Cont.}

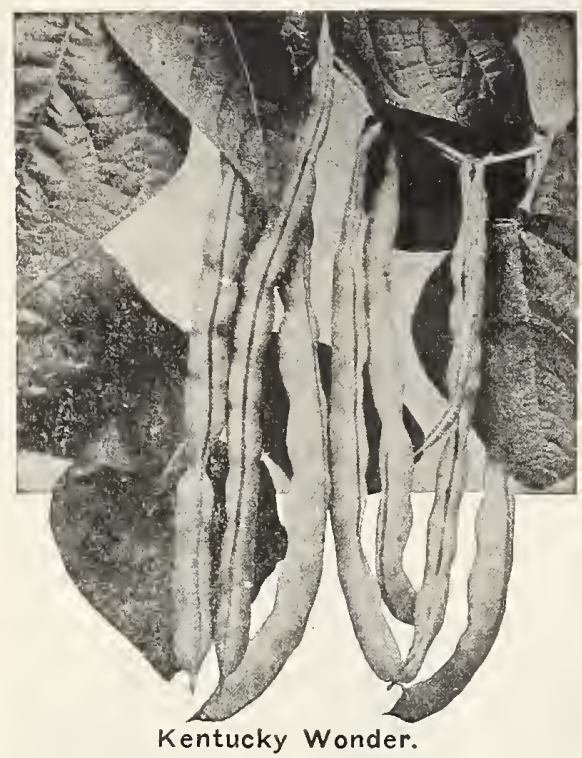

LIMAS

KING OF THE GARDEN POLE LIM.A.-An improvement on the large White Lima, producing a continuous bloom and fruitable to the end of the season. Pods are of snormous size. Pkt., 10c; $1 \mathrm{lb}$., 35c; $10 \mathrm{lbs} ., \$ 3.00$, postpaid.

HENDERSON'S BUSH LIMA.-(50 days.) Two weeks earlier than the Pole Lima. A bush strain of Sieva. Pkt. 10c; 1 lb., 35c; 10 lbs., \$2.75, postpaid.

FORDHOOK BUSH LIMA BEAN.-The only stiffly erect Bush form of the popular "Potato" Lima. Bushes of stiffly erect habit. The stalks that produce the blossoms are thrown out from the lateral and main stalks; the pods are borne in "clusters" of from four to eight.

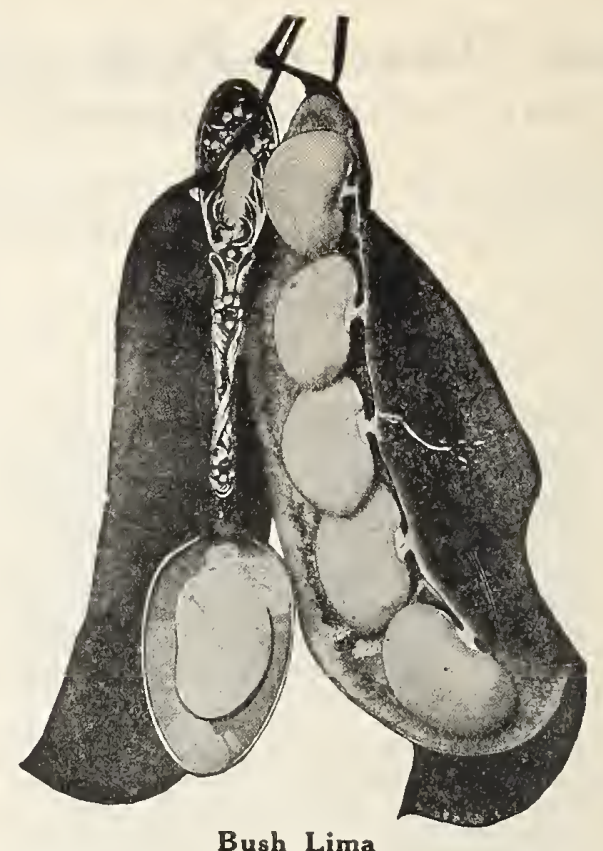

FORDHOOK is in season from four to six days earlier. The green beans even when of full size, are tender, juicy, and sweet in flavor when cooked-as distinct from the rather dry and mealy character of other varieties of the Potato Lima type. Pkt., 10c; Ib., 40c; 10 lbs., \$3.25, postpaid.

BURPEE'S BUSH LIMA.-A bush form of the true large Lima. Plants uniformly dwarf, bearing very abundantly; single plants, under favorable circumstances, yielding from 150 to 350 pods containing 4 to 6 Beans; grows only 20 inches high, branching freely; immense bearer. Pkt., 10c; 1 lb., 40c; 10 lbs., $\$ 3.25$, postpaid.

\section{BEETS}

\section{GARDEN BEETS FOR TABLE USE}

\section{Crimson Gold.}

Oaltare.-For earliest use and market sow seed of any round sort under glass in February or March, and transplant to open round in Karch or Apríl. Seed for main crop may be gown as soon round uro proper serile 14 inches ap drils 14 inches apart, and thin to stand 3 to 4 inches apart in the cown. Use 1 ounce to 100 feet of drill, and cover llghty; 6 to 8 pounds per acro The round and turnip-shaped beets are best for pring and summer, the half long kinds for winter. Make successional plantings and cultivate freely. Beet tops are much used for groens and frequently form a profitable crop with many of our market-gardener customers.

DETROIT DARK RED (Turnip-Shaped).-(45 days.) Valuable because of its uniformity, medium in size, always smooth and free from small roots. The flesh is tender, fine-grained, and remains so long after many sorts have become woody, early or late. Pkt., 10c; oz., 15c; 1/4 lb., 25c; 1 lb. 75c, postpaid.

CROSBY'S EGYPTIAN.-(42 days.) The earliest Beet on the market. A selection from that standard market Beet, Early Egyptian, which retains the earliness of the parent stock and has added thickness. It is the deepest red, almost black in color, and is of finer quality than the Egyptian, being sweeter and even more tender and smoother. The most desirable sort for small Beets for early market. It is a very rapid grower, and can be sown outside as late as July. Pkt., 10c; oz., 15c; 1/4 lb., 25c; 1 b., 75c, postpaid.

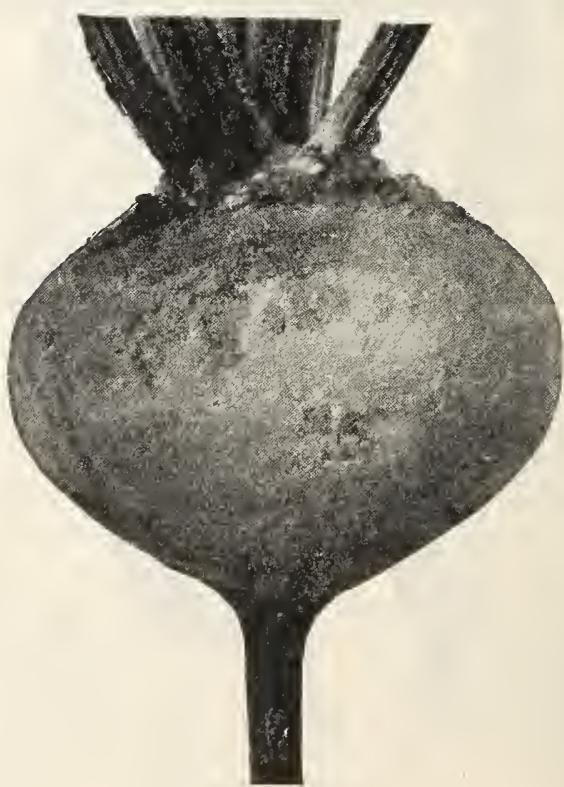




\section{GARDEN BEETS, Cont.}

ECLIPSE.-(42 days.) A very early, smooth, dark, globe-shaped Beet, with small top; in earliness and quality it is excelled by none. A good cropper. We recom. mend it for market and garden use. Pkt., 10c; oz., 15c; 1/4 Ib., 25c; 1 lb., 75c, postpaid.

CRIMSON GLOBE.-(45 days.) Root of medium size, very handsome globe shape, and has a remarkably smooth surface. Both the skin and flesh are deep, rich red, fine-grained, sweet and tender in all stages of growth. Small tap root; leaves are small. Remains so long after many sorts hare become woody. Early or late. Pkt. 10c; oz., 15c; $1 / 4$ lb., 25c; 1 lb., 75c, postpaid.

THE BANQUET.-(40 days.) Dark red early Turnip Beet. A perfect out-door forcing variety, preferable to all others for first sowing; may be sown in February or sooner, if the soil can be worked. Being a rapid grower, mas also be sown continuously as late as July. Handsome

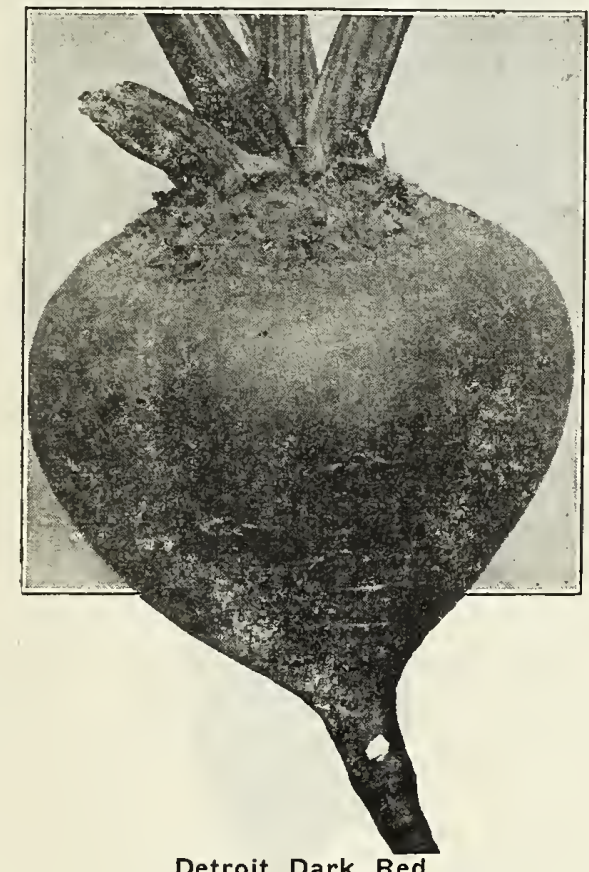

form, guod size and above all, of very superior quality Pkt., 10c; oz., 15c; 1/4 lb., 25c; 1 lb., 75c, postpaid.

EARLY BLOOD TURNIP, IMPROVED.-(45 days.) One of the most popular early sorts. Smooth and dark red. Excellent quality. Pkt., 10c; oz., 15c; 1/4 Ib., 25c; 1 lb., $75 \mathrm{c}$, postpaid.

THE ELECTRIC.-The best second-early Beet. Thoroughbred, uniform in shape and size, with smooth, dark, red skin, small leaves and a small tap root. The flesh is fine-grained and tender; color, rich red, ringed with dark crimson. An extra fine early table Beet. Pkt., 10c; oz., 15c; 1/4 Ib., 25c; 1 lb., 75c, postpaid.

\section{MANGEL AND SUGAR BEETS}

Culture.-Sow in the early spring as soon as ground can be gotien in proper condition, in drills 2 to 3 feet apart. Corer the seed with 1 inch of soil and thin to stand about 8 to 13 inche apart in the rows. Use 1 ounce to 100 feet of drill, 5 to 6 pounds per acre. A light loamy soil is best. Cultivate frequentir. Kee free from weeds

LONG RED.-A large, long variety growh for stock feeding. It stands up well above the surface; color light red: flesh white and rose colored. Oz., 10c; 1/4 lb., 20c; 1 lb., $60 \mathrm{c}$, postpaid.

GOLDEN TANKARD.-Shape cylindrical, color dee yellow, flesh yellow circled with white. Unequaled for feeding stock. Oz., 10c; 1/4 lb., 20c; 1 lb., 60c, postpaid.

VILMORIN'S IMPROVED SUIGAR. - (85 days.) A variety originating in France. It differs from the Mangel Wurzel in containing the largest percentage of sugar of any known variety. In size it is medium, yielding from 10 to 16 tons per acre, containing about 18 per cent sugar. Should be grown in deep soil. Oz., 15c; 1/4 Ib., 30c; $1 \mathrm{lb}$., 95c, postpaid.

MAMMOTH GOLDEN GIANT.-(85 days.) An improvement on the Long Yellow Mangel, being of greater size, more than half above ground, and of a russet yellow color. Remarkably even in shape, rather elongated, of vigorous growth. Fine neck and a very smooth skin. Flesh white, firm and sweet, much liked by cattle. A magnificent root, easily lifted from the ground, producing enormous crops; 40 to 60 tons per acre. Relished by milch cows and sheep. Oz., 10c; $1 / 4$ lb., 20c; $1 \mathrm{lb} ., 60 \mathrm{c}$, postpaid.

RED GLOBE.-( 85 days.) A large. globular, red sort; a better keeper than the Long Red. Produces fine crops on shallow soil; its fine grain and excellent keeping qualities render it most desirable. Oz., 10c; 1/4 Ib., 20c; 1 lb., $60 \mathrm{c}$, postpaid.

KLEIN WANZLEBEN SUGAR.-Planted for its sugarproducing qualities. Eighteen tons of sugar have been made from 100 tons of these Beets. Recommended as a winter food for milch cows. Oz., 15c; $1 / 4$ Ib., 25c; $1 \mathrm{lb} ., 75 \mathrm{c}$. postpaid.

\section{CABBAGE}

\section{GARDENERS CAN RELY UPON AYRES' CABBAGE} SEED.

acre.

Sow 1 ounce for 3,000 to 4,000 plants; 4 ounces for one

Calture.-For plants of the earlier sorts, sow seed in Jañuary or February under giass and set out in flats or frames about 2 inches 2part each way. Transplant to open ground as soon in spring as the land can be properly prepared. A rich, warm fibrous loam is best. Have the plants in the rows 20 to 24 inches apart and the rows at least 2 feet apart. Give thorough cultivation and irrigate worm, maggot and powder, etc.

HOLLAND CABBAGE.-(65 days.) Extreme size, earliness, handsome color, solidity, tender fiber, fine flavor; superior for cooking, for kraut, or for profitable market. Pkt., 10c; oz., 35c; 1/4 Ib., 90c; 1 lb., \$3.00, postpaid.

EARLY SUMMER.-Second early, somewhat flattened; valuable for home garden and takes well on market. Also well adapted for kraut. Plants are vigorous and strong growing, compact, with numerous, but not large, rather spreading, outer leaves which are somewhat frilled and sometimes rather thin and slightly undulating. Stem is rather short. Heads medium size, round, somewhat flattened, and keep longer without bursting than most early sorts. Pkt., 10c; oz. 35c; 1/4 lb., 90c; 1 lb., $\$ 3.00$, postpaid.
EARLY FLAT DUTCH.-(75 days.) A good secondearly and sure header. Tender and fine-grained. Pkto, 10c; oz., 25c; $1 / 4 \quad \mathrm{lb}$. 75c; 1 lb., $\$ 2.50$, postpaid.

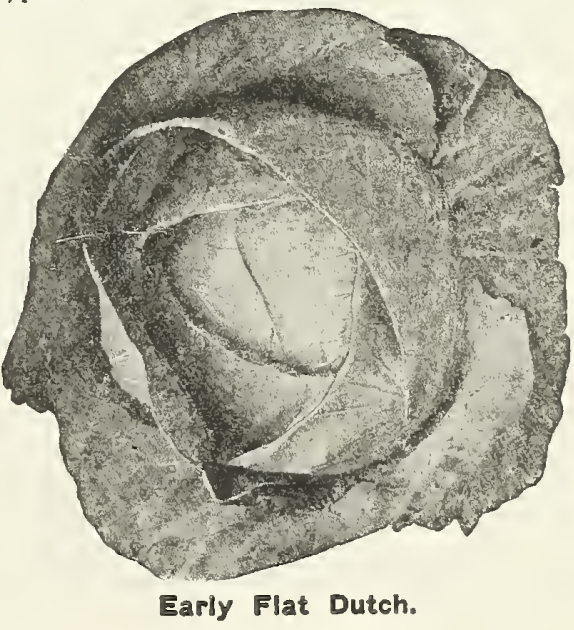




\section{CABBAGE-Cont.}

EXTRA EARLY JERSEY WAKEFIELD.-(70 days.) Select stock. Long recognized as the best very early marketable Cabbage. Medium size; in shape, pyramidal, with a pointerl peak. Is a reliable, certain header, and one of the most profitable Cabbages for the market gardener. Our strain of seed is of superior quality. Pkt., 10c; oz. $25 \mathrm{c} ; 1 / 4$ Ib., 90c; lb., $\$ 2.50$, postpaid.

EARLY WINNINGSTADT.-(75 days.) An excellent variety. Heads hard, conical in shape, and a good keeper. Pkt., 10c; oz., 35c; 1/4 Ib., $\$ 1.00$; lb., $\$ 3.00$, postpaid.

ALL SEASONS.-(80 days.) Large heads; very desirable for early spring, summer or fall use; good keeper. Pkt., 10c; oz., 35c; 1/4 lb., \$1.00, postpaid.

SURE HEAD.-(85 days.) It never fails to make a fine, solid, large head. Pkt., 10c; oz., 35c; $1 / 4$ lb., $\$ 1.00$, postpaid.

IMPROVED LATE FLAT DUTCH.-In this superior strain of late Cabbage we have combined every good quality essential to perfection. The result of several years' selection of seed stocks of the most perfect and largest heads, with low stalks, especially those that show greater earliness in heading, with few outer leaves and very uniform color. By such selection we have a highly improved strain. Market gardeners grow it in preference to all others for a main crop. It is uniform in shape, size and color. Pkt., 10c; oz., 35c; $1 / 4$ Ib., $\$ 1.00$, postpaid.

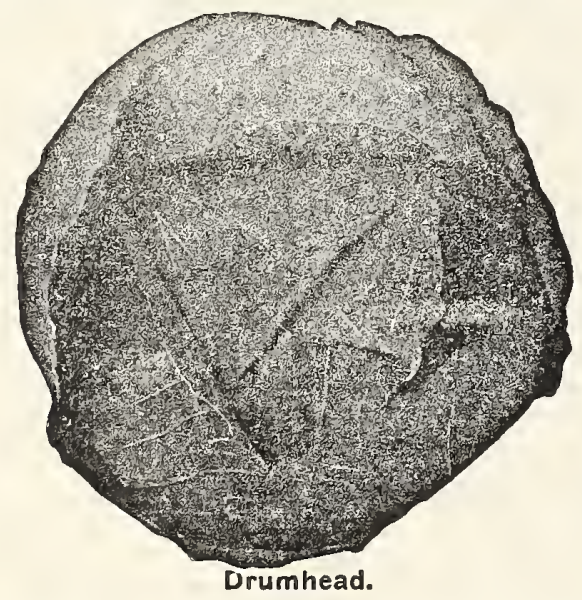

AMERICAN DRUMHEAD SAVOY (Wirsing).-The leading variety of all Savoys. Valuable for the private garden. Sweeter than other Cabbages, especially when touched by a slight frost. Pkt., 10c; oz., 35c; 1/4 Ib., 90c; 1 lb., $\$ 3.00$.

RED DRUMHEAD (Improved Large Red Dutch).-The well-known standard. Heads of large size, slightly rounded, 7 to 8 inches in diameter. Pkt., 10c; oz., 35c; 1/4 Ib., $\$ 1.00 ; 1$ lb., $\$ 3.25$, postpaid.

COPENHAGEN MARKET.- $(60$ days. $)$ Earliest round-headed Cabbage. An extra early variety, maturing same time as Jersey Wakefield, but produces larger heads than any other Cabbage equally as early. Heads average 10 pounds in weight, are ball-shaped, solid and firm, with a small core, and fine texture and quality. Seeds mature at the same time, so entire crop may be harvested at one time. Leaves are light green, tightly folded, permitting close planting, and has a short stem, growing close to the ground. Our stock is grown by the originator in Denmark and is earliest of our Danish Cabbages. Pkt., 10c; oz., $40 \mathrm{c} ; 1 / 4$ Ib., $\$ 1.35 ; 1$ lb., $\$ 5.00$.

LARGE LATE DRUMHEAD.-Enormous heads, hardy, and especially desirable for winter. Fine shipper. Pkt., 10c; oz., 35c; l/4 lb., \$1.00; 1 Ib., $\$ 3.00$, postpaid.

DANISH BALLHEAD.-One of the best winter sorts. Heads round and solid. Pkt., 10c; oz., 35c; 1/4 1b.p $\$ 1.00 ; 1$ Ib., $\$ 3.00$, postpaid.

\section{CHINESE CABBAGE}

Culture.-Same as ordinary Heading Plant.

PET-SAI.-(Original strain.) This stock comes from China, where the purest strains are grown and from where the best results are obtained in Florida planting. This is the ORIGINAL strain of Chinese cabbage that has always given success and satisfaction. Pkt., 10c; oz., 35c; 1/4 lb., $90 \mathrm{c} ; 1 \mathrm{lb} ., \$ 3.00$, postpaid.

\section{CARROTS}

Culture-Carrots will do well in any good, well-worked soil. For early use, sow when the apple is in bloom in rows 15 incheg apart, when 2 inches high thin out so that plants stand out inches apart in the row. For fall and winter use, sow seed from the 1st to 15 th of June. Roots may be stored in cellar or pit corered with dry sand, where they will keep fresh and solid until late in spring. Sow 1 ounce of seed to 100 feet of drill; 2 to 3 pounds to acre.

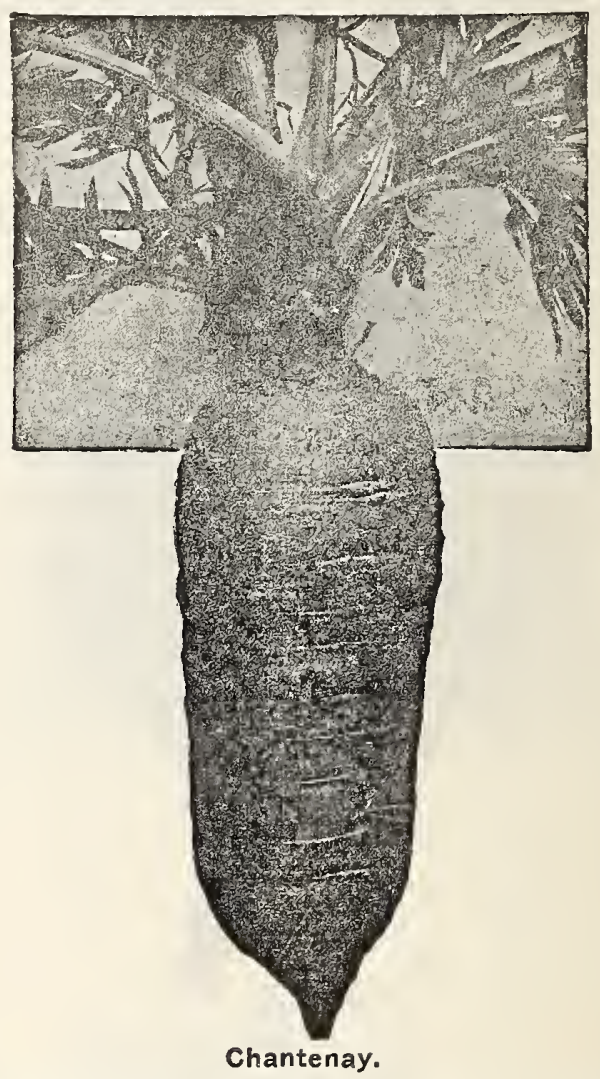

DANVERS HALF LONG.-(50 days.) Admirable in color, wonderful producer; best of all for the stock-breeder and valuable to market gardener. With this variety planters secure the largest return to acre, with least difficulty of harvesting. Pkt., 10c; oz., 15c; 1/4 ib., 25c; 1 lb., 85c, postpaid.

CHANTENAY.-(52 days.) A smooth Carrot of perfect uniform shape. Heavy yielder, fine table quality, 5 to 6 inches long, easily dug. Flesh is of a deep yellow color, tender, excellent flavor. Pkt., 10c; oz., 15c; $1 / 4 \mathrm{lb}$, 25c; 1 lb., 85c, postpaid.

OXHEART OR GUERANDE.-(48 days.) The French Carrot is one of the most valuable varieties, for family use or market. An intermediate between the half-long and the horn type, attaining a diameter of 3 to 4 inches at neck. Very productive, rich orange color, beautiful shape. Pkt., 10c; oz., 15c; 1/4 lb., 35c; $1 \mathrm{lb} ., \$ 1.00$, postpaid.

EARLY FRENCH FORCING.--Earliest variety, largely grown for forcing purposes; globular shaped root. orange red color. Pkt., 10c; oz., 15c; 1/4 lb., 35c; 1 lb., $\$ 1.00$.

\section{STOCK-FEEDING CARROTS}

IMPROVED LONG ORANGE.- - (75 days.) Old standby for stock-feeding and table use, summer or winter. Fed to milch cows, it increases the flow of rich milk and gives to butter a fine flavor and beautiful golden color. Pkt., 10c; oz., 15c; $1 / 4$ lb., $35 c$; 1 lb., $\$ 1.00$, postpaid. 


\section{CAULIFLOWER}

Culture.-A vegetable requiring very rich soil and plenty or molsture and careful attention. Not as hardy as Cabbage in registance to hot, dry or cold weather. Sow in hot-beds in January or February and when plants are large enough transplant. Set plants out 15 to 18 inches apart and rows 2 feet apart. When the heads begln to form. tie up the outer leaves to protect the head from sun and weather. One ounce will produce 2,000 plants.

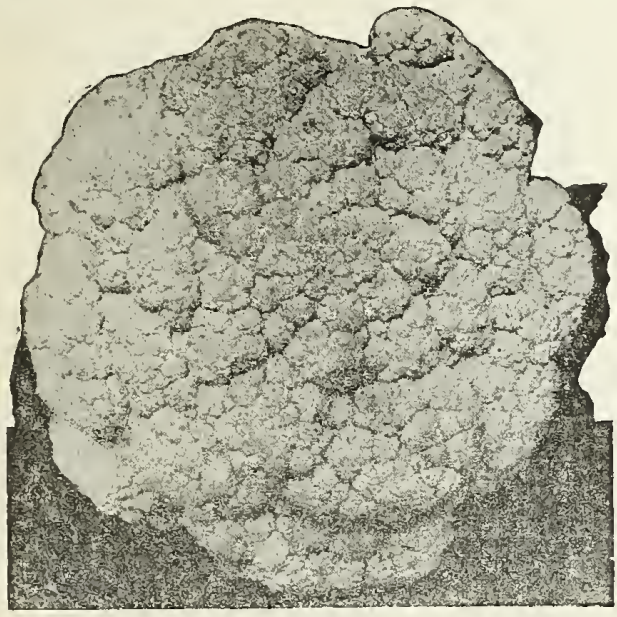

Early Snowball.

EARLY SNOWBALL.-Under favorable conditions, every plant produces a white head of fine quality. Pkt., 10 c; oz., $\$ 2.50$, postpaid.

EXTRA SELECT DWARF EARLY ERFURT.-The best in general cultivation for forcing and open ground. Head close, compact and large, measuring from 7 to 10 inches in diameter. Plants are quite dwarf, and seldom fail to form a good sized symmetrical head of flower. Pkt., 10 c; oz., $\$ 2.50$, postpaid.

\section{CRESS OR PEPPER GRASS}

Culture.-A refreshing salad of easiest culture. As soon as the ground can be worked in the spring sow thickly, broadcast, or in rows 8 inches apart. Repeated sowings may be made every two weeks for a succession.

DWARF FINE CURLED.-A small, pungent salad of easiest culture. Seed should be sown early in rows about 15 inches apart and covered lightly; when 2 or 3 inches high it is ready for use. It is often mixed with lettuce, and imparts a warm agreeable taste to the salad. Pkt., $10 \mathrm{c}$; oz., 20c, postpaid.

TRUE WATER CRESS.--Succeeds only where the roots and stems are submerged in water. A highly prized salad of a pleasant and agreeable flavor. Should be planted wherever a suitable place can be found for it. Pkt., 10c; oz., 50c, postpaid.

\section{COLLARDS}

Oulture.-This is a tall, loose-leafed cabbage-like or kale-like plant, known in different sections as "Cole," "Colewort," or simply "Greens." It is extensively used for the table, as well as for stock feeding. Sow the seed thickly in drills, in rich ground, transplanting when about 4 inches high; or sow in drills where the plants are to remain, and when well started thin to $2 \mathrm{or} 3$ feet apart in the row.

GEORGIA, SOUTHERN, OR CREOLE.-This is the white or green-stemmed variety growing 2 to 3 feet high and forming a large, loose, open head or cluster of leaves with a rather long stem. A frost, if not too severe, will improve rather than injure the quality of the leaves. Pkt., 10c; 0z., 20c; 1/4 lb., 35c; 1 lb., \$1.00, postpaid.

\section{CHICORY}

LARGE-ROOTED OR COFFEE.-Pkt. $10 \mathrm{c}$.

\section{CELERY}

Culture-Celery seed is slow to germinate and ample time must be given. Sow thin; cover lightly. Keep constantly molst. About 7,500 plants per ounce of seed or $1 /$ pound per acre. When seeding plants plants are 3 lnches hish the slat stocky growth, or transplanted. Celery is mome use to culture, wlthout trenches, rows 3 to Is often grown in double rows, 10 inches apart, wh lifting.

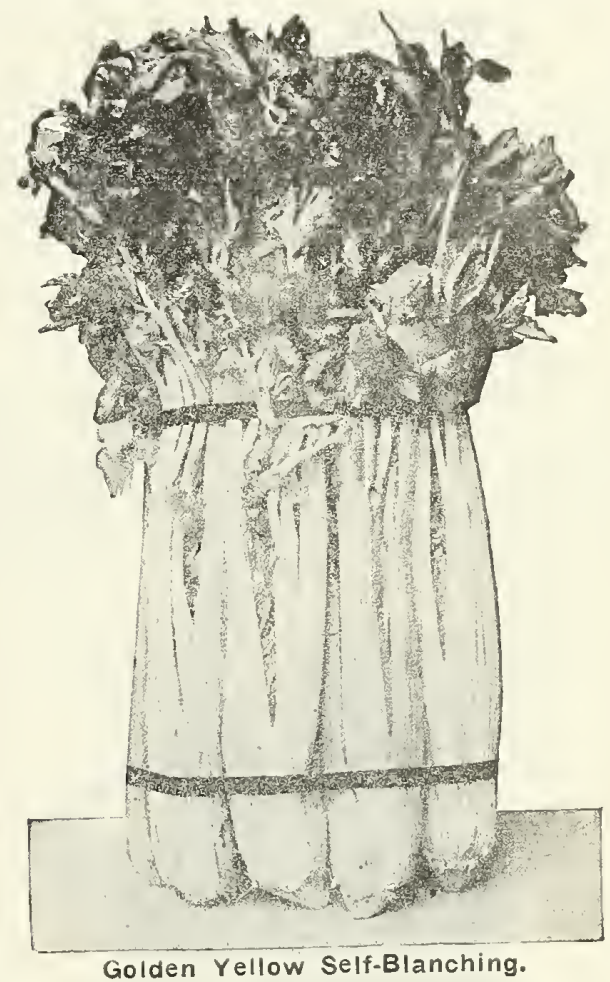

GIANT PASCAL.-Grows about 2 feet high. Stocks are broad, thick and crisp, and rich nutty flavor. Heart is golden yellow, very full and attractive in appearance; bleaches very easily and quickly. Pkt., 10c; oz., 30c; 1/4 Ib., 90c, postpaid.

GOLDEN SELF.BLANCHING.-(100 days.) A beautiful plant, of close habit, compact growth, and straight and ful plant, of close habs are sclid, crisp and brittle. Its vigorous stalks. Ribs are solid, crisp and briety, and it has the flavor is surpassed by no other variety, and it has the merit of being self-blanching to a very remaid.

gree. Pkt., 10c; oz., 30c; 1/4 lb., 90c, postpaid.

WHITE PLUME.--(110 days.) Valued because stalks and portions of inner leaves and heart are white. the tying up the stalks and drawing up soil with the hoe, the work of blanching is completed. Ornamental, tender, crisp, good flav 90c. postpaid.

\section{CELERIAC, OR TURNIP ROOTED CELERY} Culture.-In this kind of Celery roots have been developed by cultivation, and not the lea.t-stalks. The roots, which for soups and portion, keep well for winter use and

tews; also cooked and sliced as a salad. Sow secd at same season and give same treatment as Celers. Transplant to moist, rich soil in ro not necessary to earth apart in row Give thorough cultu have attained a diameter of 2

up or "liandle" plants. After roots have attained for use To keep through the winter, pack in damp earth or sand otraw put in cellar or leave like beets and carrots.

LARGE SMOOTH PRAGUE.-An improved variety of Turnip-rooted Celery, producing large roots of globular shape and smooth surface. Pkt., 10c, postpaid. 


\section{CHIVES}

ALLIUM SCHOENOPRASUM.-An Onion-like plant used as salad and for flavoring soups. Makes an excellent ornamental garden bed edging which may frequently be cut, a new growth of leaves appearing after each cutting. Plants grow about 10 inches high. One sowing will do for about three years. Pkt. 20c.

\section{CORN SALAD}

Fol winter use, sow shallow in rows 1 foot apart, in August or September. Plants are ready for use in six or eight weeks. When winter approaches, lightly cover with hay or straw. Plants are hardy and will remain green and fit for use all winter. Seed may also be sown early in spring. Pkt., 10c; oz., 40c, postpaid.

\section{CUCUMBERS}

Culture.-Flourish best in a rich, warm, sandy loam. Sow when langer of frost is over, in hills 4 or 5 feet each way. As the young plants have many enemies, sow thickly, $1 / 2$ inch deep, and then thin out finally to three or folir plants to the hill. Use 1 ounce of seen to 75 hills; 2 to 3 pounds to the acre. Gather cucumbers by cutting, not tearing. Leave none to ripen if you want a full crop. For early use plant in hills $4 x 4$ feet, on a warmer border, when the cherry is in bloom; and for a succession, sow in drills at 5 feet when the anple is in hloom. For pickles, plant in the middle of sumner.

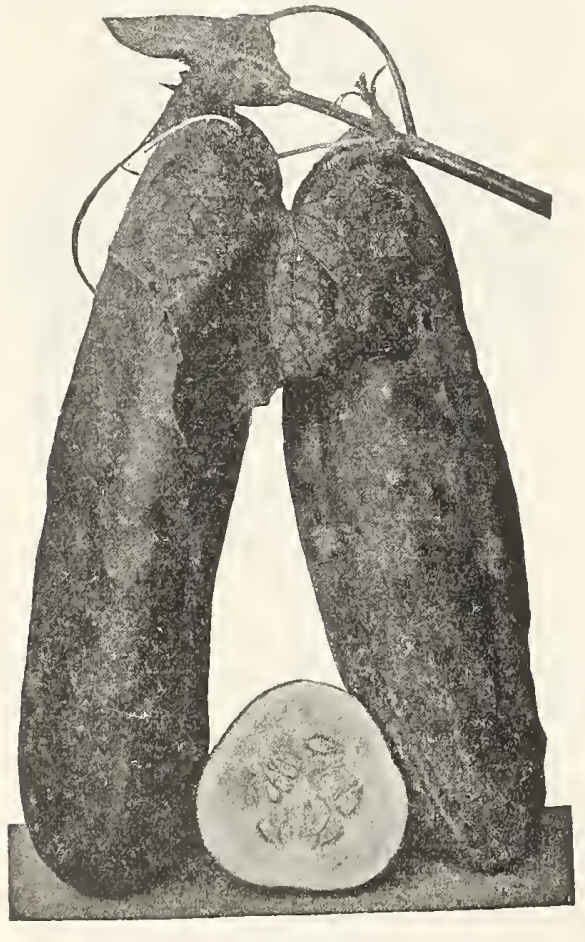

Evergreen.

DAVIS' PERFECT.-(70 days.) An early, prolific and continuous producer of large and symmetrical fruits of a deep green color, shading perfectly to ends, practically no misshapen fruits or culls. Ideal for slicing; fresh, sparkling white, refreshing. A delightful plate on the table and flavor is new. Vines are vigorous, mildew-proof and maintain their bearing from earliest to latest season. This variety best for home or market gardeners. Pkt., 10c; oz., $15 \mathrm{c}$; $1 / 4 \mathrm{lb}$., 50c; $1 \mathrm{lb} ., \$ 1.35$, postpaid.

EVERGREEN, OR EXTRA LONG WHITE SPINE.(60 days.) One of the best table sorts. A fine strain, producing smooth, regular fruits, frequently 12 inches long; smooth, round, handsomely colored and very regular in size and form; of excellent quality. Pkt., 10c; oz., 15c; 1/4 lb., $45 \mathrm{c} ; 1$ Ib., $\$ 1.35$, postpaid.
IMPROVED LONG GREEN.-(82 days.) Unquestionably the most popular general-purpose Cucumber. When matured, is 9 to 12 ichens long, very solid and crisp; retains its dark green color until nearly ripe. One of the

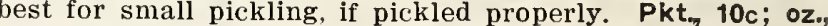
$15 c$; I/1 Ib., 45c; 1 lb., $\$ 1.35$, postpaid.

EARLY FRAME, OR SHORT GREEN.-(52 days.) An excellent sort for table use and for pickling. Fruit straight, handsome, smaller at each end; bright green; flesh tender and crisp; makes fine pickles. Pkt., 10c; oz., 15c; $1 / 4 \mathrm{lb}$, $45 c$; 1 lb., \$1.35, postpaid.

EXTRA EARLY GREEN PROLIFIC PICKLING.- $(54$ days.) One of the best for pickling. Dark green and of uniform size; very few seeds. Pkt., 10c; oz., 15c; 1/4 lb., $45 \mathrm{c} ; 1$ lb., $\$ 1.35$, postpaid.

JAPANESE CLIMBING.-(60 days.) Can be trained upon a trellis or poles, which will insure earlier ripening and a straight handsome form. Endures summer heat and drouth exceedingly well. It is entirely distinct. Quality splendid. Adapted for pickling, as well as for slicing for salads. Cucumbers are 12 inches in length. Skin smooth, dark green, turning to brown, and pitted with ribs. Flesh is pure white, crisp and of mild flavor. Pkt., 10c ; oz., 15c; 1/4 Ib., 45c; 1 lb., $\$ 1.35$, postpaid.

BOSTON OR JERSEY PICKLING.-(55 days.) A favorite Eastern sort of fine quality, medium length; reliable for pickling and slicing. Pkt., 10c; oz., 15c; 1/4 Ib., 45c; 1 Ib., \$1.35, postpaid.

EARLY GREEN CLUSTER.-(52 days.) Short and prickly bearing in clusters: prolific; fine for bottling. Pkt., 10c; oz., 15c; 1/4 lb., 45c; 1 lb., \$1.35, postpaid.

EARLY WHITE SPINE.-One of the best for table use Vines are vigorous, fruiting early and abundantly. Fruits are straight, dark green, well covered with white spines, and when inature are about 7 inches in length. Flesh is crisp, tender and excellent quality. The variety is much usea for home garden and market. Pkt., 10c; oz., 15c; $1 / 4$ lb., 45c; 1 lb., $\$ 1.35$, postpaid.

ARLINGTON.-A medium early, white-spined Cucumber, more slender than Early White spine and pointed at each end. The young fruits are crisp and tender. The ma. ture fruits are bright deep green and are about 7 inches in length, sometimes longer. This variety is extensively used for the home garden and for bulk pickles. Pkt., 10c; oz., 15c; 1/4 lb., 45c; 1 lb., $\$ 1.35$, postpaid.

KLONDIKE.-A medium early white-spined Cucumber f handsome, very dark green color and of excellent quality for slicing. The vines are very hardy and productive. The mature fruits when grown under favorable conditions The mature fruits whes in length and are uniform in size are slightly striped all shape. The dark green color is retained much longer aud is alfocted less by the hot sun than any other sort with which we are familiar. Its uniform size and shape with splendid color are making this variety very popular as a shipping sort. Pkt., 10c; oz., 15c; 1/4 lb., 45c; $1 \mathrm{lb}$., $\$ 1.35$, postpaid.

EARLY FORTUNE.- Strong and vigorous growth roducing abundant crops of cucumbers, which are longer prod cylindrical in shape and have a very dark green skin. The flesh is thick, seed cavity relatively small and the quality is excellent. Pkt., 10c; oz., 15c; 1/4 Ib. $45 \mathrm{c} ; 1$ lb., $\$ 1.35$, postpaid

\section{POP CORN}

QUEEN'S GOLDEN.-The largest Pop Corn. The talks grow 5 to 6 f'eet high and bear two to three large ears perfectly white. Lb., 15c; 10 lbs., \$1.25, postpaid.

WHITE RICE.-A very handsome and popular variety Ears short, kernels long, pointed, and resemble rice; color, white. Lb., 15c; 10 Ibs., \$1.25, postpaid. Write for Special Prices on Larger Quantities Than Listed. 


\section{SWEET CORN}

Write for Special Prices on Larger Quantities Than Listed.

Culture. Sweet Corn always does well on sod land, or where clover has been turned down. Plant when danger of frost is over, in hills $2 \times 3$ feet, according to variety. Give frequent and continued shallow culture. Leare two or three stalks to the hill, and make successional plantings until nearly mid-summer. Use 1 quart for 600 lills; 6 to 8 quarts per acre. Cover seed with 3 inches of soil.

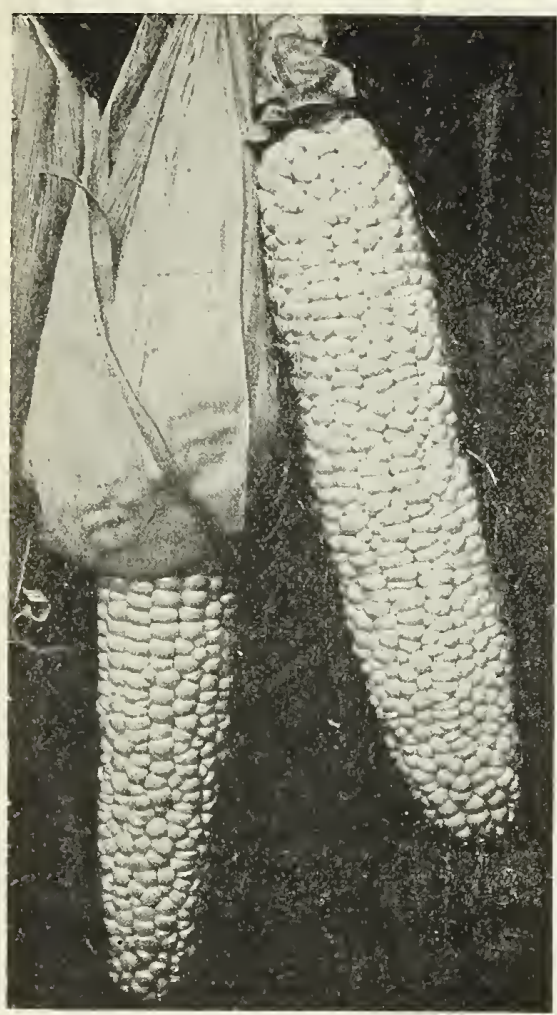

Country Gentleman.

\section{NINE EXTRA EARLY VARIETIES}

COUNTRY GENTLEMAN.-(70 days.) A shortstalked productive sort frequetlny producing three ears to the plant. Ears large for so small a stalk; grain narrow and very deep, after the fol $m$ of a shoepeg. Highly recommended as one of the very bast. Pkt., 15c; $1 \mathrm{lb} ., 30 \mathrm{c}$, postpaid.

- GOLDEN BANTAM.-(70 days.) Dwarf, 41/2 feet high, So very hardy that it can be planted earlier in the spring and in colder and damper soil than other varieties of table Corn. Exceedingly sweet, very productive, consequently a great favorite. When ready for table use, it is a creamy yellow. Growing in great demand. Pkt., 10c; $1 \mathrm{lb} ., 30 \mathrm{c}$, postpajd.

EXTRA EARLY MINNESOTA.-(60 days.) Among the extra early Sugar Corns, coming two or three days after Corey. Ears well made out. Pkt., 10c; $1 \mathrm{lb} ., 30 \mathrm{c}$, postpaid.

EARLY EVERGREEN.-Like Stowell's Evergreen, only ten days earlier. Ears large, about 18 inches long, 12 to 16 -rowed, and having the identical flavor of the famous Stowell's Evergreen. It remains green a remarkably long time, and the kernels retain the sweetness and tenderness which is so characteristic of Stowell's. Pkt., 10c; 1 lb., 30c, postpaid.

WHITE COREY.- (62 days.) Stalks 4 to $4 \frac{1}{2}$ feet high. A valuable sort; quite robust for a short-stalked and exceptionally early sort. Ears of good length ; that is, 6 to 7 inches; grains large. sweet and tender. Pkt., 10c; $1 \mathrm{lb}$., $30 r$, postpaid.
ADAMS' EARLY.-(68 days.) In order of maturity after the Extra Early Adams. Pkt., 10c; 1 lb., 30c, postpaid.

EXTRA EARLY ADAMS, OR EARLY BURLINGTON. (62 days.) Height of stalk, 4 feet; ears set within 6 inches of the ground. Not a Sugar Corn, but a decided acquisition so very early in the season. Plant close in rows at $2 \frac{1}{2}$ feet and thin to 1 foot. Pkt., 10c; $1 \mathrm{lb}$., 30c, postpaid

\section{LATE VARIETIES}

STOWELL'S EVERGREEN.-( 80 days. $)$ The most popular among the late Sugar Corns. More bushels are used than all other sorts combined. Large, tender, very deep, milk-white grains. Pkt., 10c; $1 \mathrm{lb} ., 30 \mathrm{c}$, postpaid.

LATE MAMMOTH SUGAR.-This is the latest and largest of all the Sugar Corns. The ears are immense, and of finer quality and flavor. Pkt., 10c; $1 \mathrm{lb}$., 30c, postpaid.

\section{SWISS CHARD}

\section{(Spinach Beet)}

Culture,-Sow in well prepared soil between April 15th and Tune 15th. One ounce will sow 50 feet of drill Sow in drills 18

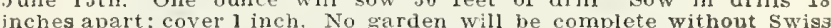
chard, and the grower will be amply rewarded by giving it at least amall space.

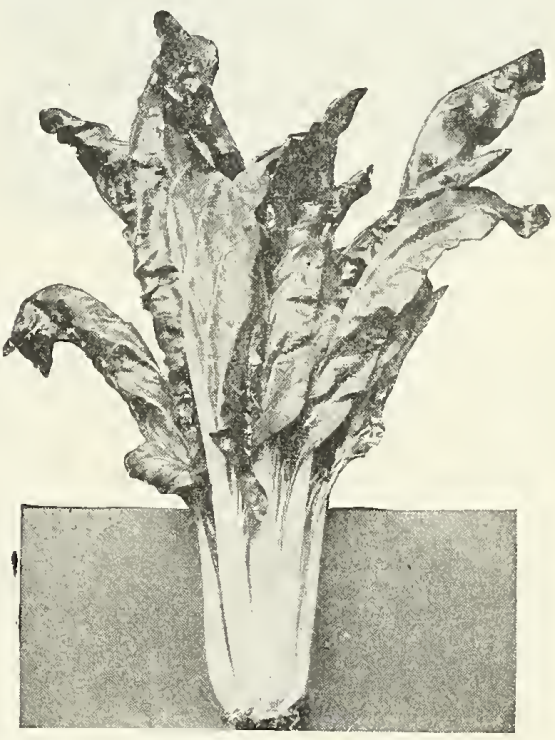

Also called Sea Kale Beet. The middle of the leaf, or midrib, is cooked and served like asparagus. The other portions of the leaf may be used like spinach. This Beet does not make a large root, but is a delicious summer vegetable when cut young and used for "greens." There are several varieties of Swiss Chard. We recommend the Lucullus where the rib of the leaf is to bo used. When wanted as a substitute for spinach, the Yellow cutting variety. We supply either sort at: Pkt., 10c; oz., 15c; 1/4 Ib., 35c; 1 lb., \$1.00, postpaid.

\section{ENDIVE}

Two ounces of szed to 100 yards of row; 3 pounds to the acre.

Culture.-Sow in the spring as soon as the earth is free from frost, and repeat to rvithin 60 days of autumn frost. Drill in rows 2 feet and thin the plants to 8 inches apart. Tie up the loose leaves or cover with pots to blanch for salarl. Valuable for salads and highly decorative as a garnish.

IMPROVED GREEN CURLED.-Finely fringed leaves of bright green color: tender and crisp when properly blanched. Pkt., 10c; oz., 15c; 1/4 lb., 35c, postponed.

WHITE CURLED. - The thick center leaves are a pale yellow color, while the finely cut and curled outside leaves are pure white. Does not need blanching. Large size, and always tender and crisp. Pkt., 10c; oz., 15c; $1 / 4 \mathrm{lb}$. $35 \mathrm{c}$, postpaid. 


\section{THE BRYSON AYRES SEED CO:}

\section{EGG PLANT}

Culture.-Thrives well in any good garden soil. Sow seed in hot-bed or greenhouse in March or April, and when an inch high pot in 2 or 3 -inch pots or pot out in shallow boxes 4 inches apart each way. Plant in open ground when danger of frost is past, in rows 2 feet apart each way. One ounce will yield 2,000 plants. nixture, with arsenate of lead, Paris green or Bug Death.

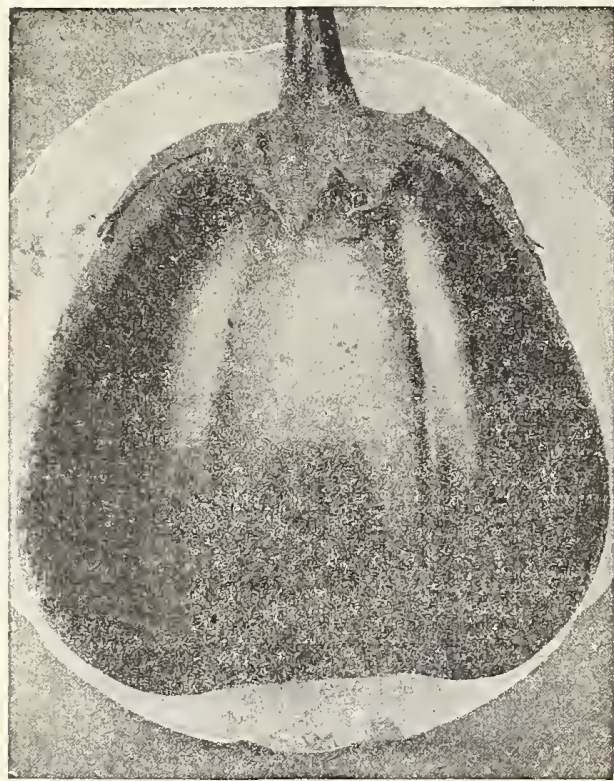

New York Improved Purple.

NEW YORK IMPROVED PURPLE.-One of the best and largest varieties in cultivation. Our strain of this variety is especially fine. The plant is robust, low-growing, branching freely and bears long, oblong shaped fruits. We think this variety better than any other. Pkt., 10c; oz., 40 c; 1/4 Ib., \$1.25, postpaid.

BLACK BEAUTY.--Ten days or two weeks earlier than the preceding, with fruits just as large, uniform and rich. lustrous black color. Fruit develops very quickly and planters will be pleased with it. Pkt., 10c; oz., 40c; $1 / 4$ lb., $\$ 1.25$, postpaid.

\section{GARLIC}

Used for flavoring soups, sausages, etc. It is propagated by division of the loots into small parts. The bulbs are gathered in August in the same manner as onions. $\mathrm{I} / 2 \mathrm{Ib} ., 25 \mathrm{c} ; 1 \mathrm{Ib} ., 40 \mathrm{c}$, postpaid.

\section{HERRS-Sweet, Medicinal and Pot}

\begin{tabular}{|c|c|c|}
\hline & Pkt. & $\mathrm{Oz}$. \\
\hline ra & $\begin{array}{l}10 \mathrm{c} \\
10 \mathrm{c}\end{array}$ & $\begin{array}{l}20 c \\
20 c\end{array}$ \\
\hline r. & $10 \mathrm{c}$ & $20 c$ \\
\hline & $10 \mathrm{c}$ & $20 \mathrm{c}$ \\
\hline & $.10 \mathrm{c}$ & $25 c$ \\
\hline m, sweet & $.20 c$ & $50 \mathrm{c}$ \\
\hline & $.20 \mathrm{c}$ & $50 \mathrm{c}$ \\
\hline r Savory & $20 \mathrm{c}$ & $50 \mathrm{c}$ \\
\hline & $20 \mathrm{c}$ & $50 \mathrm{c}$ \\
\hline
\end{tabular}

\section{LEEK}

Culture.-Similar to onions in flavor, but do not form a thlch bulb. Sow as early as possible, $1 / 2$ inch deep. when plants are large enough to handle transplant to rows 12 inches apart, setting plants 6 inches apart. Hill up as they grow to bleach stems or plant in trench like Celery and fill in as they grow. Seed may be sown in Septcmber and transplanted in spring. Ounce will sow 100 feet of drill.
LONDON FLAG.-Sow early in spring in drills, 1 inch deep and 1 foot apart. When 6 or 8 inches high, transplant in rows 12 inches apart and 5 inches between the plants as deep as possible that the neck may be blanched. An ounce will sow 150 feet drilled. Pkt., 10c; oz., 25c, postpaid.

\section{KALE OR BORECOLE}

Culture.-Used for yreens in fall, winter and spring; sown broadcast or in drills 18 inches apart from early September to mid dle of October: can be sown in February and March Spring or Smooth Kale is best. This ls also used in fall, as it make greens quicker than other varieties. Should be protected with straw or coarse litter in winter, so that plants can be cut tinroughout the season. Winter varieties can be sown at rat throughpounds to acre; Spring Kale can be sown broadcast at rate of 8 pounds to acre; Spring Kale can be so
pounds per acre; 4 or 5 pounds in drills.

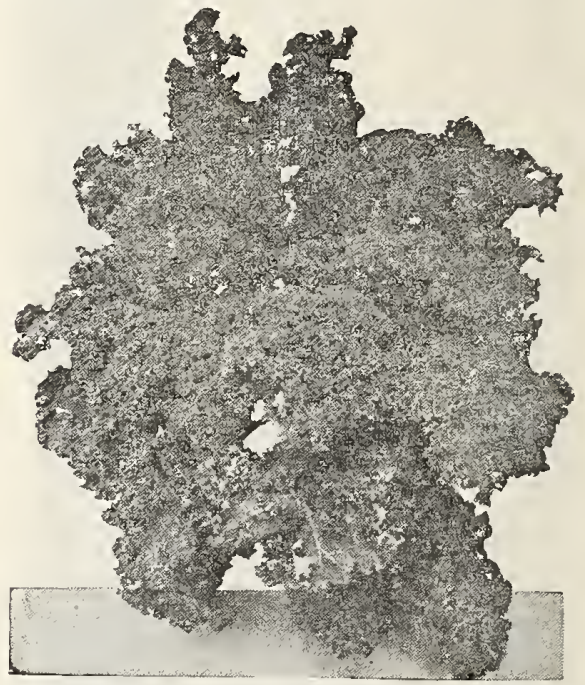

DWARF GREEN CURLED SCOTCH.-Grows about 12 inches high and spreads, under good cultivation, to 3 feet in diameter. Leaves bright green, beautifully curled, very tender. Allow to get a touch of frost before using. Pkt., 10c.; oz., 20c; 1/4 lb., 45c, potspaid.

\section{KOHLRABI}

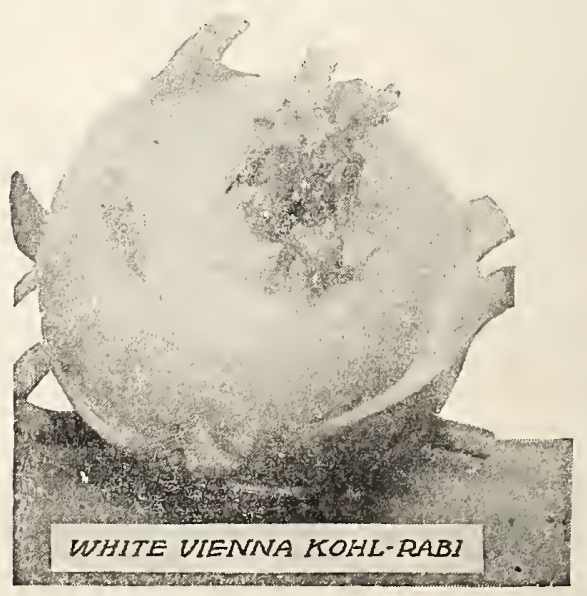

EARLY WHITE VIENNA.-Extra fine for forcing. 'This variety is extremely early, with small tops. Bulbs are of medium size, light green or naarly white; best quality for table when 2 inches in diameter. Pkt., 10c; oz., 15c; $1 / 4$ lb., 40c; 1 lb., \$1.25, postpaid. 


\section{LETTUCE}

2 ounces of seed to 100 yards of row: 3 pounds to the acre. Forty to 50 days from seeding to maturity.

Culture. - For eally outduor cuiture, the seed may be planted in March or as early as the ground can be worked. Sow in drills 14 inches apart, and thin the plants to 4 inches apart. For the heading varieties, thete la? ge hea ls are desired, plants should be thinned 8 to 10 inches to row Latuce shoul il be grown very rapthinned 8 to 10 inches to row. Leituce sioula be grown very rapldly; therefore the sol should be as
manuring and tinorough preparation.

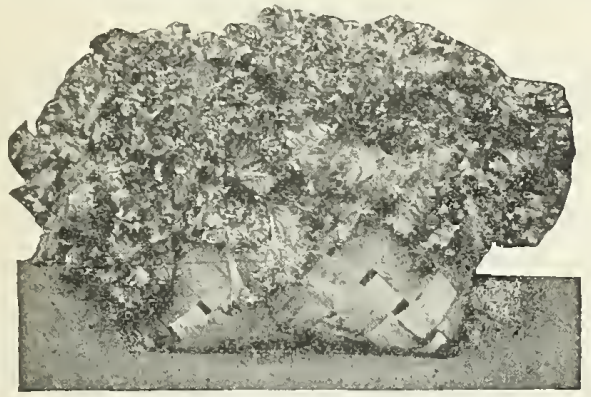

Grand Rajids.

OUR BIB BOSTON LETTUCE.-( 40 days.) The king of main-crop head Lettuce. Elanches beautifully; crisp, tender and free from bitterness. It produces immense heads, solid as cabbage: often 15 and 16 inches across and weighing enormousy. A very large, robust-growing variety, rooting deeply, l'asisting hot, dry weather; slow to run to seed, and a sure header under most trying conditions. Outer color is cf distinct apple agreen. Been extensively grown by our ctstumers in almost all sections of the country, from whom we receive most gratifying reports. Pkt., 10c; oz., 15c; $1 / 4 \mathrm{lb} ., 35 \mathrm{c}$; $1 \mathrm{lb} ., \$ 1.00$, postpaid.

PRIZE HEAD.-(38 dajs.) Very tender leaves of dark reddish brown color. variegat 2 d with dark green. Heads other brown-leaved variety. Pkt., 10c; oz., 15c; 1/4 lb., $35 \mathrm{c}$; 1 lb., \$1.00, postpaid.

DENVER MARKET.-(15 days.) Used either for forcing or open ground. An ea:ly variety, forming heads which are solid and of beauciful light green color, curled somewhat like Savoy Cabbage, and always crisp and tender. Pkt., 10c; oz., 15c; l' lb., 35c; 1 lb., $\$ 1.00$, postpaid.

IMPROVED HANSON.- 40 days.) Forms very large, firm heads, res mbling Cabbage, which are deliciously sweet, crisp and telldrr: heads green outside and white inside. For outdoer culture unexcelled. It is one of the best heat-resisting sorts. Pkt., 10c; oz., 15c; 1/4 lb., 35c; $1 \mathrm{lb} ., \$ 1.00$, postpaid.

MAMMOTH BLACK.SEEDED BUTTER.-A smoothleaved Lettuce, forming vəry largə, compact, cabbage-like heads of thick, yellowisi green lavis, the inner ones beautifully blanched, very crisp, tender and buttery. It is one of the most largely g"own sorts, suitable for the home garden as well a s maiket. Pkt. 10c; oz., 15c; 1/4 lb., 35c; 1 lb., $\$ .100$, postpaid.

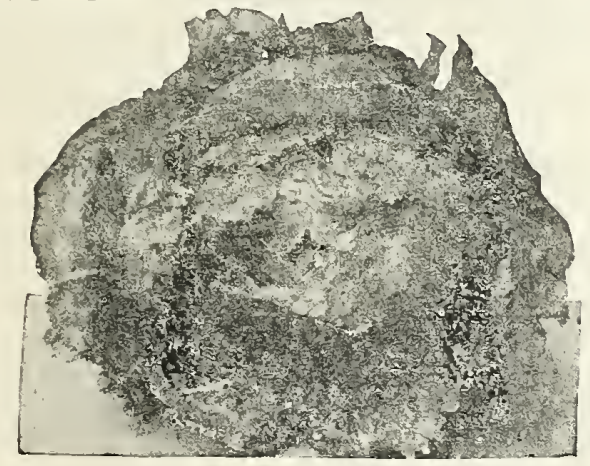

Big Boston

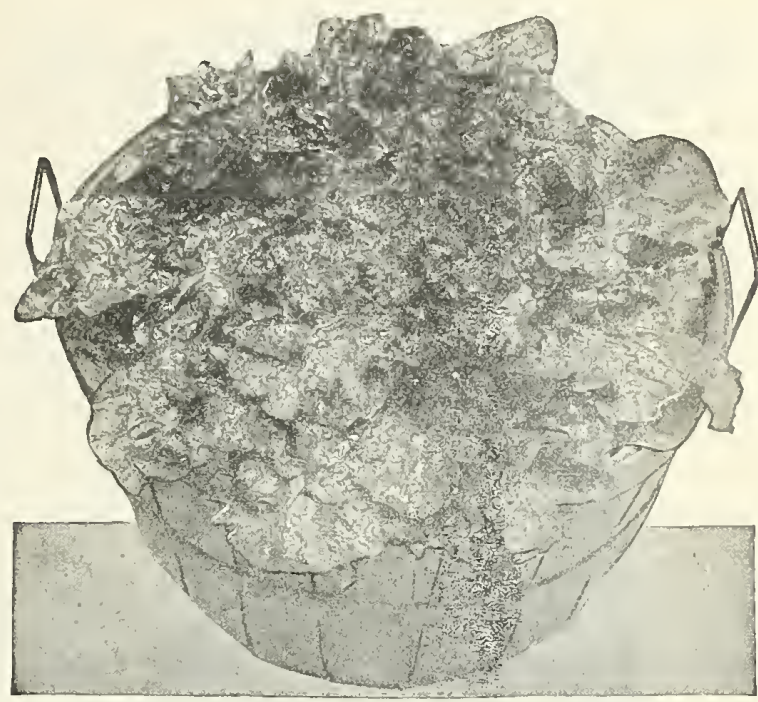

NEW YORK.-The large white heads resemble cabbage in their solidity, and frequently weigh two and three pounds each. Tha quality is superb, being crisp, rich and tender. It witbstands the heat well, making a fine variety for all seasons. Pkt., 10c; oz., 30c; $1 / 4 \mathrm{lb} ., 90 \mathrm{c} ; 1 \mathrm{lb} ., \$ 3,00$, postpaid.

BLACK-SEEDED SIMPSON.-(40 days. $)$ An old standard, used largely for forcing and for early and late outaoor culture. Stands heat and drouth well. Leaves large, thin, and very tender, of a light green color, slightly curled. A fine sort for all seasons. Pkt., 10c; oz., 15c; $1 / 4$ Ib., 35c; 1 lb., $\$ 1.00$, postpaid.

EARLY CURLED SILESIA.-(38 days.) Old favorite; awarf, compact habit and quick growth, crisp golden leaves; finely curled edges. Pkt., 10c; oz., 15c; $1 / 4$ lb., 35c; 1 Ib., $\$ 1.00$, postpaid.

GRAND RAPIDS.-(40 days.) A forcing variety of superior quality and appearance. strong grower, free from rot, keeps crisp and tender without wilting when exposed for sale longer than any other forcing Lettuce. Also desirable for sowing in open ground. Pkt., 10c; oz., 15c; $1 / 4$ lb., 35c; 1 lb., \$1.00. postpaid.

EARLY CURLED S!MPSON.-(40 days.) A good forcing sort. White-seed ad. Resembles, the Black-Seeded Simpson Early. Pkt.. 10c; oz., 15c; 1/4 lb., 35c; 1 lb., $\$ 1.00$, postpaid.

PARIS WHITE COS-Grows to very large size. The inner leaves blanch readily and are of fine flavor. One of the most popular market sorts; also called White Paris Self-Folding Cos or Trianon Cos. Pkt., 10c; oz., 20c; 1/4 lb., 60c: Ib., \$2.00, postpaid.

\section{WATERMELON}

3 ounces of seed to 100 yards of row; 4 pounds to the acre.

Culture-Watermelons do well upon sod ground or upon land prepared for their reception by plowing down a crop of winter wheat or wintel rye, the soll or grain aerating or keeping loose the soi When the apple is in bloom the seed is planted in hills 10 feet apart in each direction Two large shovelfuls of well-rotted stabl manure should be dug and trampled into each hill and covered with earth. The cultivator should be prepared with quite 4 pounds of seed to the acre, that he may have a reserve for replanting in case of destruction of his plants by insect desredations or beating rains. Only one vine to the hill should be allowed to attain perfection. With 450 hills to the acre, there should be 900 first class melons.

SWEET HEART.-( 80 days.) Early, large, oval, light green; splendid shipper. Pkt., 10c; oz., 15c; 1/4 Ib., 30c; 1 lb., 75c, postpaid.

GEORGIA RATTLESNAKE.-(90 days.) Melons are long in shaps, of light green color, with dark stripes, and grow of uniformly large size and symmetrical shape. In Georgia this valiety is one of the most highly prized of all. The rind is remarkably thin, though it stands shipping well, and the flesh most tend $r$, sweet, and luscious, it being a rare thing to find a melon that is not of superior quality. Pkt., 10c; oz., 15c; $1 / 4 \mathrm{lb} ., 30 \mathrm{c} ; 1 \mathrm{lb} ., 75 \mathrm{c}$, postpaid. 


\section{WATERMELON—Cont.}

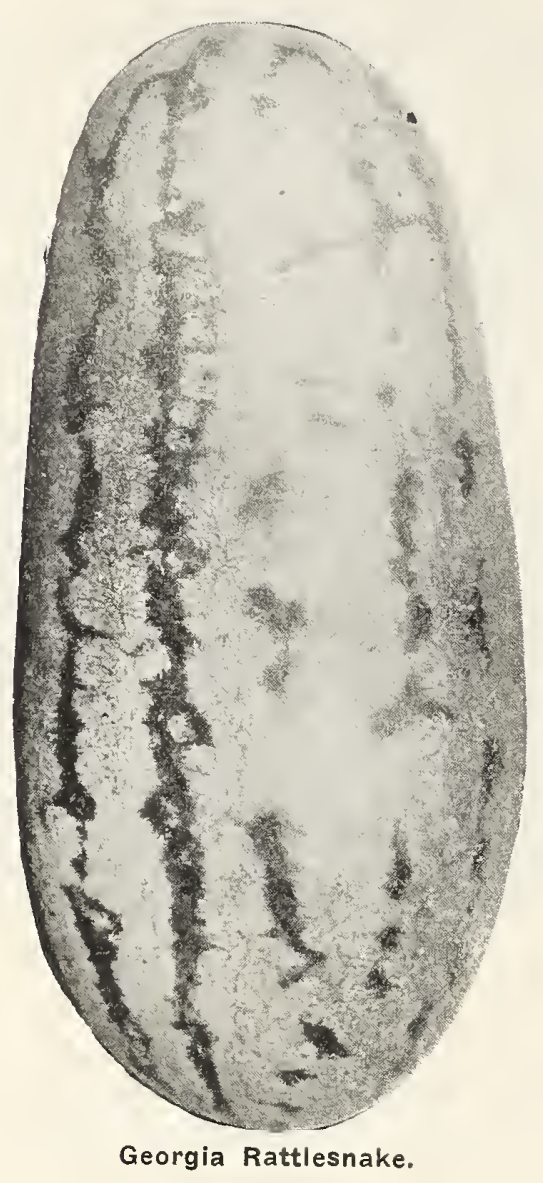

TOM WATSON.-(85 days.) A new variety, destined to become a leader among Melons because of quality and shipping excellence. There is no variety, to our knowledge, that conıbines both essentials as does this Melon. Most sorts of extra quality are not tough enough to ship, and most shipping Melons are too tough to excel in quality. The Tom Watson is a large, oblong Melon, the skin of which is dark green, with thick netting on the entire surface, guite distinct from other varieties. It averages 18 to 24 inches long and 10 to 12 inches in diameter, and weighs 50 to 60 pounds. The rind is thin, but tough, and flesi a bright, attractive red color, crisp, sweet and delicious. The heart is large, with no core. Seeds brown, tipped white. Pkt.; 10c; oz., 15c; 1/4 lb., 30c; 1 lb., 75c, postpaid.

HALBERT HONEY.-(85 days.) Too much cannot be said of the merits of this grand new sort for market or home purposes. Its vine is of strong, vigorous growth, and sets fruit freely. Seed white. Flesh is bright red, exceedingly sweet and tender; absolutely stringless. Good keeper. In size it is large to mammoth, and presents a fine appearance on the market, as well as the dining table. Seed direct from the originator. Pkt., 10c; oz., 15c; 1/4 1b., $30 \mathrm{c}$; $1 \mathrm{lb}, 75 \mathrm{c}$, postpaid.

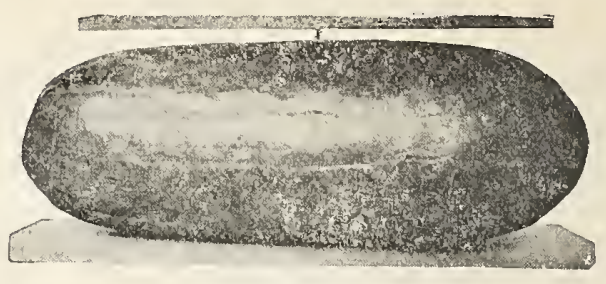

Tom Watson.

KLECKLEY SWEET.-(85 days.) This is one of the best flavored Melons in cultivation and of a shape and color that is extremely desirable. The rind is very dark green, very thin, flesh deep scarlet, fine, and of delicious quality. For the lome market and family garden it is decidedly the best. Pkt., 10c; oz., 15c; 1/4 lb., 30c; 1 lb., 75c, postpaid.

ALABAMA SWEET.-(95 days.) A very large, long Melon of fine quality, very popular in the South, where it is grown extensively for shipping. Rind firm, rather dark green, slightly striped; flesh bright red, seed white. Pkt., 10c; oz., 15c; 1/4 Ib., 30c; 1 Ib., $75 c$, postpaid.

ROUND LIGHT ICING.-Fruits are small-medium, nearly round; greenish white, slightly veined or dotted with light green. Flesh is bright, light red, sweet and tender; seed white. Pkt., 10c; oz., 15c; $1 / 4 \mathrm{lb} ., 30 \mathrm{c} ; 1 \mathrm{lb}$., $75 \mathrm{c}$, postpaid.

COLE'S EARLY.-(78 days.) A hardy, sure cropper; nearly round; flesh dark red; rind thin and extremely brittle; medium size; green striped with lighter shades. Pkt., 10c; oz., 15c; 1/4 lb, 30c; $1 \mathrm{lb} ., 75 c$, postpaid.

PHINNEY'S EARLY.-(80 days.) Medium size; flesh a deep red; rind thin. Pkt., 10c; oz., 15c; 1/4 lb., 30c; $1 \mathrm{lb}$., $75 \mathrm{c}$, postpaid.

FLORIDA FAVORITE.-(90 days.) Large, oblong; rind dark green, with stripes of lighter green. A popular variety in the South. Pkt., 10c; oz., 15c; 1/4 lb., 30c; $1 \mathrm{lb}$., $75 \mathrm{c}$, postpaid.

CITRON, RED-SEEDED.-For pickles and preserves ouly. Unpalatable in raw state. Pkt., 10c; oz., 20c; 1/4 lb., 50c; 1 lb., \$1.50, postpaid.

KOLB'S GEM.-(95 days.) Has no superior for shipping purpoess. Fruit large, oval-shaped, marked with mottled; brittle; medium size; green striped with lighter shades. Pkt., 10c; oz., 15c; 1/4 lb., 30c; $1 \mathrm{lb} ., 75 c$, postpaid.

ICE CREAM, OR PEERLESS.-(90 days.) Popular for home market. Medium size, almost round; skin pale green, slightly mottled; flesh bright scarlet, fine-grained. None better. Pkt., 10c; oz., 15c; 1/4 lb., 30c; 1 lb., 75c, postpaid.

HARRIS'S EARLIEST.-An extra early Melon of exrellent quality. Fruits are exceptionally large for so early a variety, slightly oval with irregularly mottled broad stripes of light and dark green. Flesh is bright red, sweet and tender. Seed black. Vines are vigorous and productive. One of the best varieties for Northern latitudes. We have carefully observed this variety in our trials for several seasons and are convinced that it is the best first early melon for the home garden. Pkt., 10c; oz., 15c; $1 / 4$ lb., 30c; 1 lb., 75c, postpaid. 


\section{CANTALOUPE OR MUSKMELON}

Two ounces of seed to 100 yards of row; 4 pounds to the acre.

Culture.-Melons do best in sandy soil or sod land and the soil should be made rich. The hills can be put 4 to 6 feet apart, with 10 to 12 seeds in each hill. Plant the seeds an Inch deep. When vation should be kept up as long as possible. One ounce of seed is sufficient for 50 hills; 2 pounds per acre. Plant in May or June.

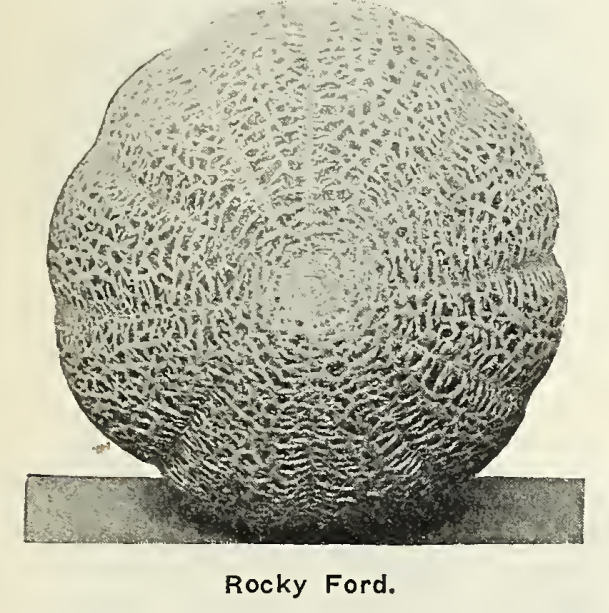

\section{GREEN-FLESHED VARIETIES}

ROCKY FORD.- $(70$ days. $)$ This has become one of the most popular of small or crate Melons, and is shipped in large quantities from Colorado and Arizona. The vines are vigorous and productive. The fruits are oval, slightly ribbed, densely covered with fine netting. Flesh green, very sweet and highly flavored. We offer an exceptionally fine stock of this early sort, the fruit being very uniform in shape and quality and of the even size that is so desirable in a shipping Melon. Pkt., 10c; oz., 15c; 1/4 Ib., 40c; $1 \mathrm{lb} ., \$ 1.35$, postpaid.

NETTED GEM.-(70 days.) In many sections considered an improvement on the Rocky Ford because of its more perfect netting, safeguarding it against abrasion or ribs. Pkt., 10c; 0z., 15c; 1/4 Ib., 40c; $1 \mathrm{lb} ., \$ 1.35$, postpaid.

EXTRA EARLY HACKENSACK.-(70 days.) We offer distinct stock, very different from and much superior to that often sold as Extra Early Hackensack. The fruits are nearly two weeks earlier than Hackensack, medium to large sized, nearly round or somewhat flattened. evenly and deeply ribbed, and with very coarse netting. The skin is green. slightly tinged with yellow as the fruit matures; the flesh is green, a little coarse, but juicy and sweet. Pkt., 10c; oz., 15c; 1/4 lb., 40c; 1 lb., \$1.35, postpaid.

HONEY DEW.-The Melon with an appropriate name. A new menıer of the Melon family, propagated after seven years of experimenting. The new fruit, which is called the Honey Dew Melon, is a cross between the Rocky Ford Cantaloupe and a South Sea Island fruit. Pkt., 10c; oz., 15c; 1/4 lb., 40c; 1 lb., $\$ 1.35$, postpaid.

HACKENSACK.-A large, deeply netted Melon, flattened at the ends, of most delicate flavor and very productive. Pkt., 10c; oz., 15c; 1/4 lb., 40c; 1 lb., $\$ 1.35$, postpaid.

\section{ORANGE-FLESHED VARIETIES}

BURRELL'S GEM.-(80 days.) A truly delicious Melon for home use, or if you desire a fancy price on the market we recommend the Burrell Gein. About same size and shape as Rocky Ford. Has rich golden yellow flesh of

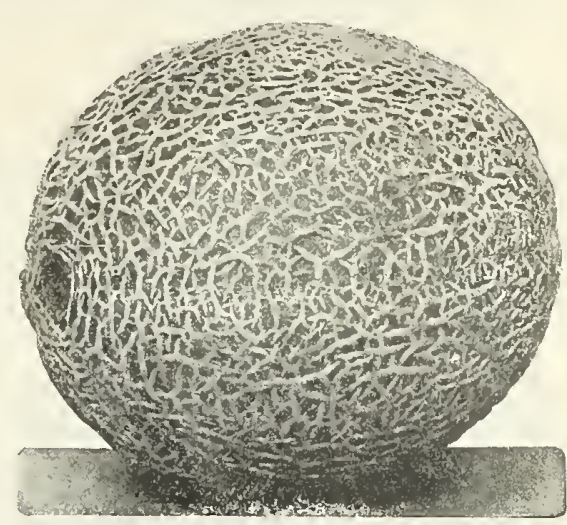

Burrell's Gem.

most delicious flavor, solid, and a most desirable shipping sort. Seed cavity very small. Melons average about 6 inches long, $4 \frac{1}{2}$ inches in diameter, and weigh $21 / 4$ pounds. Shipments to Chicago, St. Louis, New York and elsewhere brought 50 per cent more than best Rocky Fords. Pkt., 10c; oz., $15 \mathrm{c}$; $1 / 4 \mathrm{lb} ., 40 \mathrm{c} ; 1 \mathrm{lb}$., $\$ 1.35$, postpaid.

EXTRA EARLY OSAGE.-(75 days.) Fully a week earlier than the Osage, fruits a little smaller, more nearly round, and the netting extends over more of the surface. These very desirable features, combined with the thick, deep salmon-colored flesh and small seed carity characteristic of the Osage, make this Melon deserving of a place in every lome and market garden. Pkt., 10c; oz., 15c; $1 / 4$ Ib., 40c; 1 lb., $\$ 1.35$, postpaid.

BANANA.-Exterually it is of a creamy white or delicate straw color. 'The flesh (the Melon being nearly solid) is of a rich salmon. The quality is first rate when the Melons are thoroughly ripe. It grows from 18 inches to 2 feet in length, and is very prolific. When ripe, it smells like a banana. Pkt., 10c; oz., 15c; 1/4 lb., 40c; 1 lb., \$1.35, - postpaid.

CASABA MUSK MELON.-(140 days.) A class of late maturing Melons which do not ripen on vines in the North, but are gathered before freezing weather and stored in a cool place and brought to a warm room for ripening; can be eaten any time to Christmas, as they keep very long. Pkt., 10c; oz., 15c; 1/4 lb., 40c; 1 lb., $\$ 1.35$, postpaid.

EMERALD GEM.-A variety of excellent quality. It is of medium size. Skin is perfectly smooth and a deep emerald green color. Flesh is thick and of a suffuse salmon color, and ripens to the green rind. Peculiarly crys. talline in appearance and so very juicy that it almost drops to pieces when dipped out with a spoon. Flavor is very sweet and luscious. The vines are hardy and very prolific, and the Melons mature extremely early. Pkt., 10c; oz., 15c; I/4 Ib., 40c; 1 Ib., \$1.35, postpaid.

TIP-TOP MELON.-This Muskmelon should be planted by every gardener. Always pleases. The testimony of all is that every Melon whether large or small, early or late, is a good one; sweet, juicy, finest flavor, firm, but not hard fleshed, and edible to the outside coating. Its appearance on the market is very attractive. Gardeners tell us that their customers soon learn to pick them out and will have no other kind. Fruit is large size, nearly round, evenly ribbed, and moderately netted. Perhaps the most productive Melon known. Pkt., 10c; oz., 15c; 1/4 1b., 40c; $1 \mathrm{lb} ., \$ 1.35$, postpaid. 


\section{MUSTARD}

One ounce will sow 50 feet of row.

Culture,- The leaves of these varieties of Mustard, as here listed, make excellent sreens, of sharp pungent flavor, and are cooked the same as spinach or beet leaves. Sow the seed in drills early in the spring and at frequent intervals throughout the sum. mer to secure a constant supply of fresh greens. Mustard is hardy and easily grown.

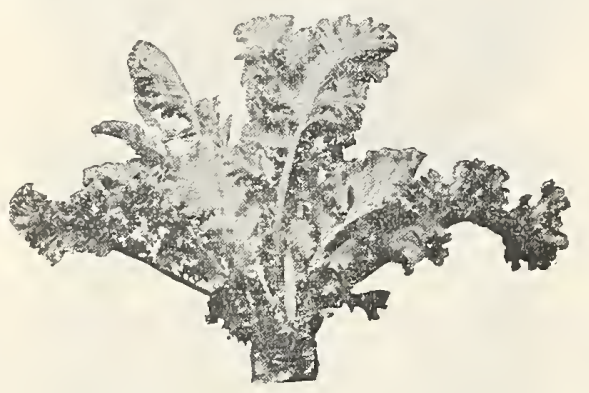

Ostrich Plume.

OSTRICH PLUME.-Most beautiful variety, of very superior flavor. These leaves are beautifully ruffled and curled and curve outward, like graceful ostrich plumes. They are excellently adapted for garnishing. It originated in the South, and stands hot weather exceedingly well. Sow in February, March or Aril, or during September and October. Pkt., 10c; oz., 15c; 1/4 lb., 25c; 1 lb., 75c, postpaid.

SOUTHERN GIANT CURLED.-Highly esteemed in the South, where seed is sown in fall and plants used early in spring as salad. Seeds brown. Plants 2 feet high; enormous bunches. Pkt., 10c; oz., 15c; 1/4 Ib., 25c; 1 lb., $75 c$, postpaid.

CHINESE.--A giant curled variety, with leaves double size ordinary. Pkt., 10c; oz., 15c; 1/4 lb., 25c; 1 lb., 75c, postpaid.

WHITE.-Leaves are light green, mild, and tender when young; seed light yellow in color. Pkt., 10c; oz., 15c; I/4 Ib., 25c; 1 lb., 75c, postpaid.

BROWN OR BLACK MUSTARD.-More pungent in Ilavor than the white. Seed black. Pkt., 10c; oz., 15c; 1/4 lb., 25c; 1 lb., $75 c$, postpaid.

\section{MUSHROOM SPAWN} prices.

AMERICAN PURE MUSHROOM SPAWN.-Write for

\section{NASTURTIUM}

Culture.-Nasturtiums are useful for furnishing tender seed-pod which makes delicious pickles. Seeds for pickling should be gathered while green and with portion of stem attached. Pick them over and place in a jar until filled; cover them with cider vinegar brought to the boil and is still warm, to keep for winter use.

TALL OR DWARF MIXED._-Pkt., 10c; oz., 15c; $1 / 4 \mathrm{lb} .$, $30 \mathrm{c}$; 1 Ib., $\$ 1.00$.

\section{OKRA OR GUMBO}

Culture-Okra is a highly esteemed vegetable throughout the entire country and the demand is getting bigger and bigger all the time. The young, tender pods are used mainly in soups and stews, although they are excellent when boiled and served hot or cold as a salad. Some persons may not enjoy the flavor of Okra at first, but after eating it a few times a taste for it is naturally acquired. Plant 1 ounce of seed to 50 feet of row; about 8 pounds to the acre. Three-foot rows are good, planting the seed 3 to 4 inches apart to allow space for the development of the stem.

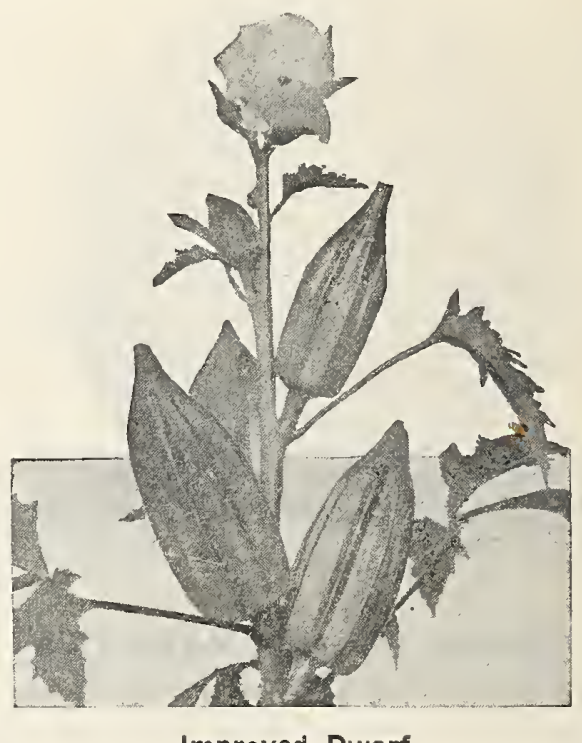

Improved Dwarf.

MAMMOTH LONG-PODDED OKRA.-This is a distinct variety and is largely cultivated for shipping purposes. Very productive, pods starting to shoot out within three or four inches from bottom of stalk, and the whole plant is covered with them to the height of 5 to 6 feet. Pods are of an intensely dark green color of unusual length, frequently 9 to 10 inches long. Are slim and do not harden as is usually the case with other slender sorts. Pkt., 10c; oz., 15c; 1/4 Ib., 25c; 1 lb., 65c, postpaid.

IMPROVED DWARF.-An early variety; pods short, but very numerous. Pkt., 10c; oz., 15c; I/4 Ib., 25c; 1 lb., $65 \mathrm{c}$, postpaid.

WHITE VELVET.-Pods large, white, smooth, superior quality, an excellent bearer. Pkt., 10c; oz., 15c; $1 / 4$ lb. $25 c ; 1 \mathrm{lb} ., 65 c$, postpaid.

\section{ONION}

Onion growers who use large quantities of seed should write for special prices.

Culture.-One ounce will sow 100 feet of drill. To grow large onions from seed, sow 5 pounds to the acre; to grow small sets 60 to 70 pounds to the acre will be required.

Raising a crop of onions requires too much labor and expense to run the risk of planting anything but reliable seed. There is no other vegetable in which the quality of the seed exerts so great an influenre. Fully realizing the importance of good seed, we have made quality our first consideration in the growing and marketing of Onion seed. Our stock is all home-grown from choice selected bulbs, and is the hest that can be produced We guarantee every pound of Onion seed to be new seed of high germlnation. Our seed is all tested, and we know it will grow and give satisfaction. It would be folly to send you poor seed. The risk is too great to take chances on cheap, poor seed. Buy our seed and get the hest. 


\section{ONION-Cont.}

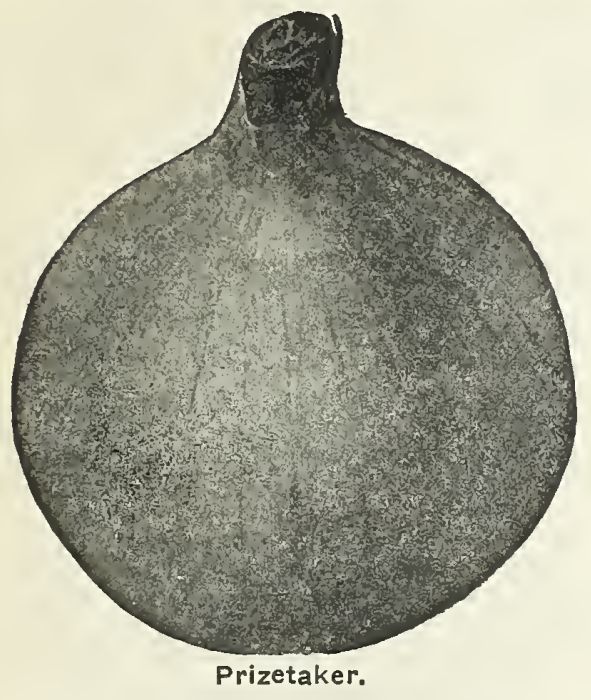

PRIZETAKER.-(90 days.) This is beyond question the handsomest Onion grown. Yellow or straw color, flesh white, of enormous size, in many cases weighing from 3 to $3 \frac{1}{2}$ ounds. Very hardy and a good keeper. Flavor sweet, very mild and tender. Pkt., 10c; oz., 20c; 1/4 lb., 50c; 1 lb., $\$ 1.75$, postpaid.

YELLOW GLOBE DANVERS.-(100 days.) A very handsome, round American variety of large size; very fine and mild; an excellent keeper. Pkt., 10c; 0z., 20c; 1/4 lb., $60 \mathrm{c} ; 1 \mathrm{lb} ., \$ 2.00$, postpaid.

SOUTHPORT WHITE GLOBE.-(100 days.) One of the most beautiful Onions grown, being symmetrical globe shape, with a smooth satin-white skin, forming a perfect silver ball. It grows to a large size, averaging $71 / 2$ to 9 inches in circumference, and is solid and heavy. The flesh is purest white, close and fine-grained, mild and of moderate flavor. It is a heavy cropper, yielding under good culture up to 900 bushels per acre. Our strain of this seed is grown from picked thin-necked bulbs, which ripen so uniformly and so thoroughly that the Onions keep nearly as well as the Red and Yellow varieties. Pkt, 10c; oz. $20 \mathrm{c} ; 1 / 4$ Ib., 60c; $1 \mathrm{lb}$., $\$ 2.00$, postpaid.

LARGE RED WETHERSFIELD.-The standard variety throughout the West, as they are the most hardy, and an immense crop can be raised when more tender varieties are not profitable. One of the best winter keepers. It is not an early ripening sort, but continues to grow throughout the season, consequently making very large Onions. The outer skin is a deep rich purplish red, flesh white, lightly tinged with pinkish rose. Our seed of this variety is extra select and cannot be excelled. Pkt., 10c; oz., 20c; $1 / 4$ lb., 50c; 1 lb., $\$ 1.75$, postpaid.

SOUTHPORT YELLOW GLOBE.-(110 days.) Th $\Theta$ true Southport Onions are very handsome globes of superior quality. They are excellent keepers, uniform in size and form, and command higher market prices than any other kind. We highly recommend the Yellow Globe. It ripens a little earlier than the Red, grows to an average size of 2 to 3 inches in diameter, and has all the good qualities mentioned above. Pkt., 10c; oz., 20c; 1/4 Ib., 50c; 1 lb., \$1.75, postpaid.

SOUTHPORT RED GLOBE.-(100 days.) The handsomest of all the Red Onions; large, solid and of perfect shape. Red Globe is the latest of the Southport Onions, ripening from a week to ten days after the Yellows. The bulbs are uniform, of a rich, red color, ripen evenly, and yield the largest percentage of marketable Onions. They ripen down hard and solid, keep well, and their beautifu appearance insures a ready market. Southport Red Globe will yield a heavier crop than either the Yellow or White Globe. Pkt., 10c; oz., 20c; I/4 lb., 50c; 1 lb., \$1.75, postpaid.

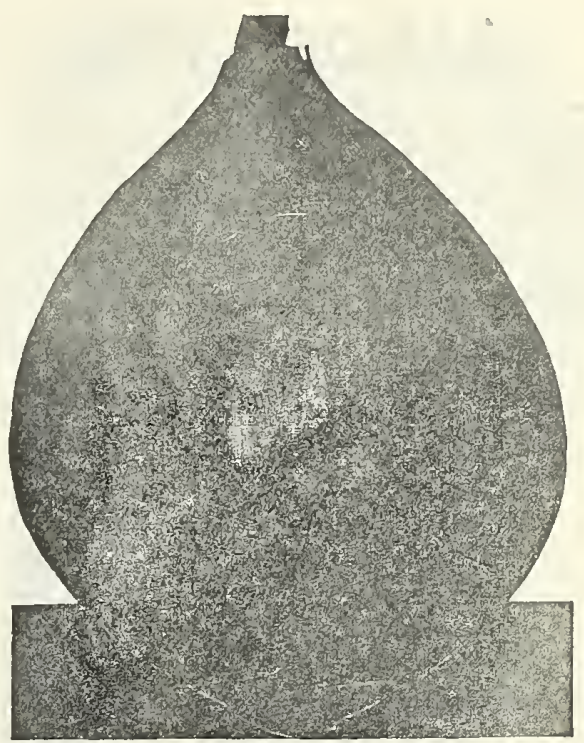

Yellow Globe.

WHITE PORTUGAL, OR SILVERSKIN.-A large flat White Onion of mild and pleasant flavor, hard and fine grained and a good keeper. Extensively sown for sets, and is also largely grown for pickling. Pkt., 10c; oz., 20c; $1 / 4$ Ib., $60 \mathrm{c}$; $1 \mathrm{lb}$., $\$ 2.00$, postpaid.

AUSTRALIAN BROWN.-A long keeper; early, a fine cropper. Pkt., 10c; oz., 20c; 1/4 lb., 60c; 1 lb., $\$ 2.00$, postpaid.

\section{ONION SETS}

Culture.-To raise Onion sets from seed, use good ground prepared as for large onions and sow the seed very thick in broad drills using 40 to 60 pounds per acre. If the seed is sown thin, the bulbs will not only be too large for sets, but will not be of the right shape, and if sown thick on poor land they will be necky or bottleshaped. Onion seed sown for sets may be planted somewhat later than if a crop of large bulbs is desired.

RED AND YELLOW BOTTOM SETS.-Treated precisely as top Onions are, setting them out in the spring instead of sowing seed. Lb., 20c, postpaid; 20 Ibs., \$2.50, postpaid.

WHITE SILVERSKIN. - Produce beautiful White Onions early in the season. Lb., 25c, postpaid; 20 Ibs., $\$ 3.00$, postpaid.

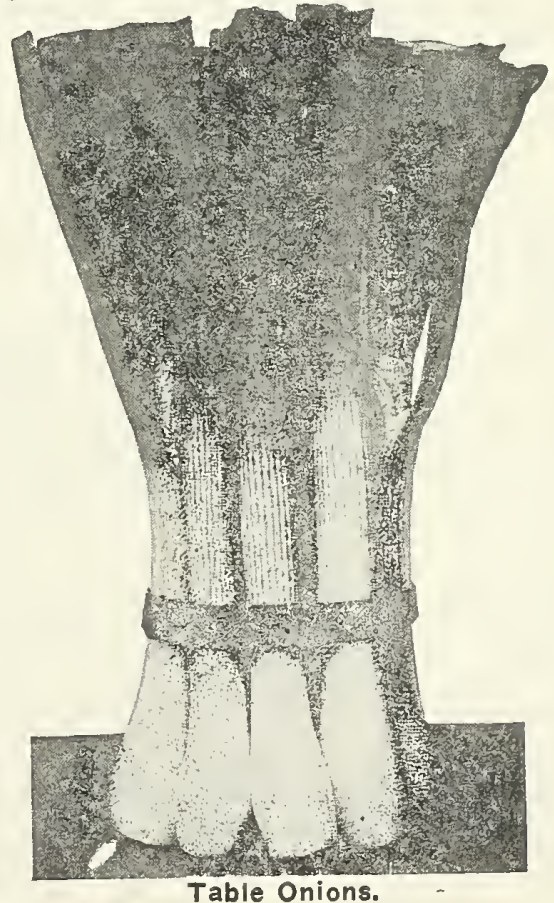




\section{GARDEN PEAS}

Culture-Sow as early as possible a few of some of the early varieties in warm sandy soil. The seed can be sown in rows in very satisfactory way. It is best to sow in an open way with a hoe the full width of it, and broadcast the seed thinly in the bottom, Later plantings should be of the wrinkled varieties; they are better yielders, sweeter, and very highly flavored. A pint will sow of 50 feet. Use from $11 / 2$ to $13 \%$ bushels to the acre from 24 to 3 feet apart Ground should bus two weeke, keeping weeds and grass free from will matare in about 50 or 60 days, later varieties in about 70 to 85 days

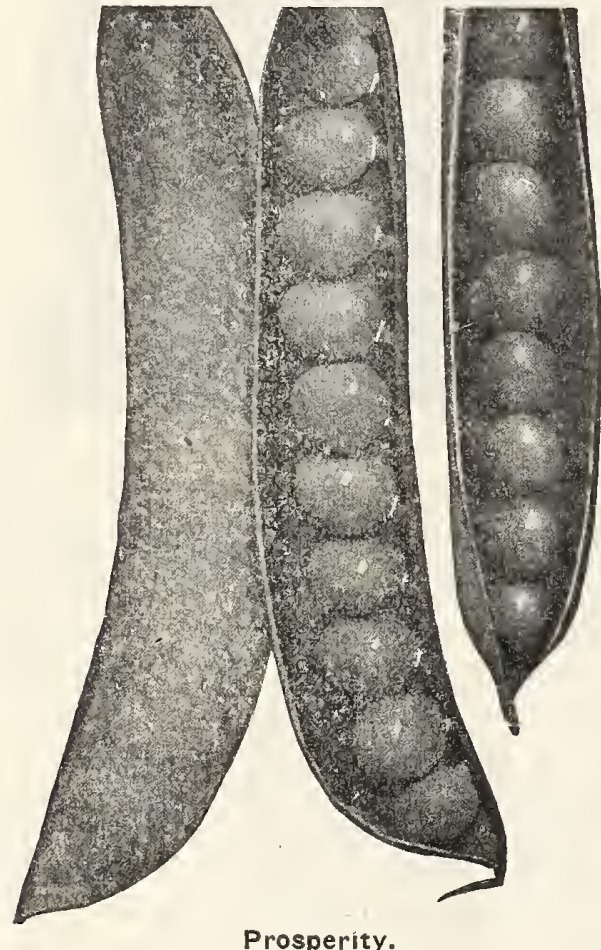

Prosperity.

ALASKA.-(45 days.) Without doubt the earliest and best smooth Blue Pea, ranking with the First-and-Best as to evenness, uniformity in ripening and earliness. Ripens all the crop at once; an invaluable variety for market gardeners and canners. Vines 2 to $2 \frac{1}{2}$ feet high. Pkt., 10c; 1 Ib., 25c; 10 lbs., $\$ 2.00$, postpaid.

NOTT'S EXCELSIOR.-(53 days.) Fifteen inches. Dwarf Wrinkled Pea. The pods average fully one-third larger than the American Wonder, and it is all ready for picking at one time. Each pod contains six to eight large peas, which are unusually sweet. Pkt., 10c; $1 \mathrm{lb}$., 35c; 10 lbs., \$2.75, postpaid.

FIRST-AND-BEST.-(47 days.) A round-seeded Pea that can be sown when frost is barely out of ground, before it is safe to sow wrinkled-seeded sorts. This, with its quick growth and maturity, renders it the earliest Pea on record. Unequaled for general excellence, yield, size of pod and regularity. It is $2 \frac{1}{2}$ feet high. Pkt., 10c; 1 lb., 25c; 10 Ibs., \$2.00, postpaid.

GRADUS, OR PROSPERITY.-(58 days.) This Pea is not only large and of best quality, but nearly as early as the small, round, extra early sorts. It is hardy and may be planted as soon as ground is fit to work in the spring, along with smooth Peas. Vine grows about 30 inches. Pods are a light green color and measure 4 inches or more in length, being as large as Telephone and as well filled; 8 to 10 in a pod. The Peas are fine table quality, and retain their color and attractive appearance after cooking. It is a grand Pea. Pkt., 10c; 1 lb.; 35c; 10 lbs., \$2.75, postpaid.

\section{MAIN-CROP VARIETIES}

THOMAS LAXTON.-An early variety of large-podded Pea, which is very hardy and a strong grower, producing pods in abundance. The habit and growth of vine resem. bles Gradus, although the color is darker and pods more blunt in shape. The pods are well filled with large peas; height, 3 feet. By express or freight, at purchaser's expense. Pkt., 10c; lb., 35c; 10 lbs., $\$ 3.00$.

BLISS EVERBEARING.- $(60$ days.) A green-seeded, wrinkled, slightly flattened variety. Height, about 2 feet. Very hardy, a vigorous grower and an enormous cropper. Pods and peas of large size and superior quality. Pkt., 10c; $1 \mathrm{lb} ., 35 \mathrm{c} ; 10 \mathrm{lbs} ., \$ 2.75$.

AMERICAN WONDER.-(55 days.) The earliest of the wrinkled Peas and best for family use. Very dwarf, 9 inches high, and remarkably productive; well-filled pods: flavor unsurpassed. Pkt., 10c; 1 lb., 35c; 10 lbs., $\$ 2.75$, postpaid.

MCLEAN'S LITTLE GEM.-(58 days.) Eighteen inches. A few days later than First-and-Best. Matures in eight weeks. When in a green state the Peas are sweet and delicious. Pkt., 10c; 1 lb., 35c; 10 lbs., \$2.75, postpaid.

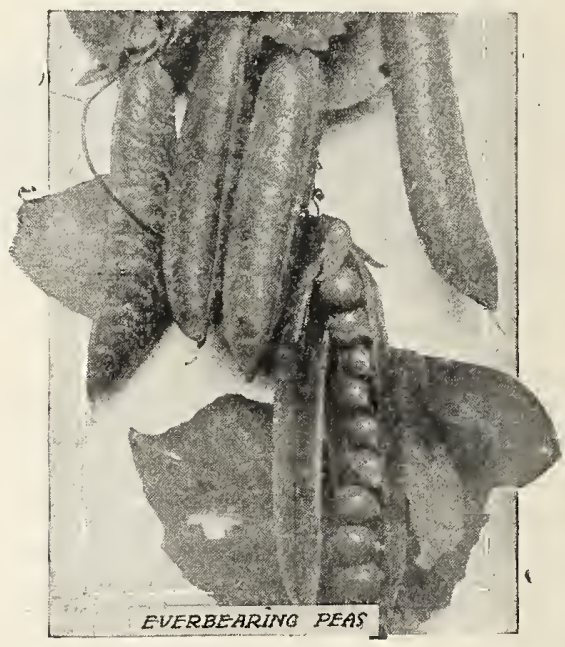

CHAMPION OF ENGLAND.-(62 days.) We offer a select strain of this grand old favorite, too well known to require extended description. It is a main crop and late variety of vigorous growth, about 5 f'eet high. Pkt., 10c; 1 lb., 35c; 10 lbs., $\$ 2.75$, postpaid.

TELEPHONE,-Large-podded variety of Pea for general crop. Vines are very strong in growth and average 18 to 20 pods per stalk. The pods are of large size, containing 6 to 7 peas each, which are a pale green color and of delicious flavor. Height, $31 \frac{1}{2}$ feet. Pkt., 10c; $1 \mathrm{lb}$., 35c; 10 lbs., \$2.75, postpaid.

STRATAGEM-Vines strong, vigorous and covered with immense pods, many measure 5 inches in length and contain 10 fine large, richly flavored, uniform wrinkled peas. Peas are dark greenish color, and are tender and sweet. Pkt., 10c; 1 lb., 35c; 10 lbs., \$2.75, postpaid.

WHITE MARROWFAT.-(65, days.) A favorite sort. Five feet. Pkt., 10c; $1 \mathrm{lb}$., 30c; $10 \mathrm{lbs}$., $\$ 2.25$, postpaid.

CANADA FIELD PEAS.-For dairy cows and hogs they are equal to corn and six weeks earlier. Should be sown early in April with Oats, using 2 bushels of Oats and 2 bushels of Peas per acre. Peas should be sown first and plowed under to a depth of about 4 inches, then sow and harrow in the Oats. Ready to cut in July. As fertilizer, they come next to Clover and will grow on land that will not produce Clover. Lb., 20c; 10 lbs., $\$ 1.50$. 


\section{PARSNIP}

One ounce will sow 200 feet of drill; 5 pounds will sow an acre in drills.

Culture.-Parsnips are uusally grown on deep, rich, sandy soll, but will make good roots on any soil which is deep, meliow and moderately rich. Fresh manure is apt to make roots coarse and IIl-shaped. As seed is sometimes slow and uneven in growth. It shouid be sown as eariy as possible, in drills $2 \frac{1}{2}$ feet apart; cover 1/3 Inch deep and press the soil firmly over the seed. Give frequent cultivation, thin the plants to 6 inches apart in row,

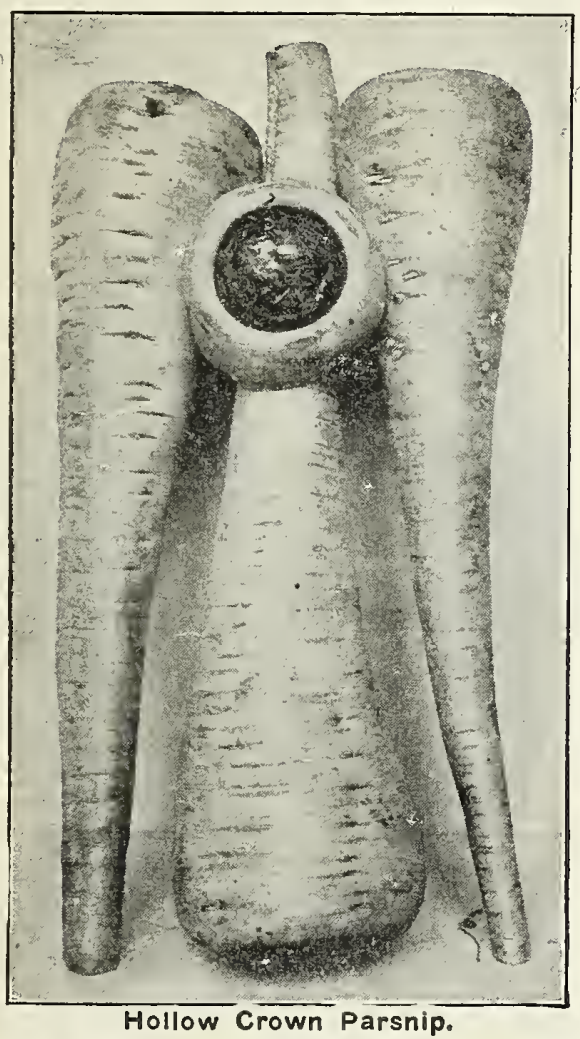

IMPROVED TABLE GUERNSEY.-A greatly improved and wonderfully fine strain of the Guernsey Hollow Crown Parsnip. The roots do not grow as long as the Hollow Crown, but are of greater diameter and more easily gathered. A very heavy cropper. Roots are smooth, with a deep hollow crown and a small top. Flesh fine-grainea, sweet, and of excellent quality; cooks evenly, center being as fine, soft, even quality as outside portion. Pkt., 10c; oz., 15c; $1 / 4$ lb., 30c; 1 lb., $75 c$, postpaid.

IMPROVED HOLLOW CROWN.-This greatly improved strain is about the same shape as the old sort, but smoother and of more even quality; fine grained and excellent. Pkt., 10c; oz., 15c; $1 / 4$ lb., 30c; $1 \mathrm{lb} ., 75 c$, postpaid.

\section{PEPPER}

Culture.-Sow the seed $1 / 2$ inch deep in hot-bed, greenhouse or warm window in March or April. After all danger of frost, set out in open ground. A warm, moist soil is best, with plenty of rotted manure plowed under Set in rows 2 to 3 feet apart and 18 inches apart in the rows. Cultivate frequently throughout the season to keep the soil mellow and free from weeds. One ounce will produce about 1,500 plants: $1 / 4$ pound to transplant for an acre.

LARGE BELL, OR BULL NOSE.-Farly and mild; a favorite for pickling; very prolific. Pkt., $10 \mathrm{c} ; 0 \mathrm{z.}, 50 \mathrm{c} ; 1 / 4$ Ib., $\$ 1.50$, postpaid.

CHINESE GIANT. - The largest red variety. Early in ripening and immensely productive for so large a Pepper. Its enormous size will cause it to sell most rapidly. Monstlous fruits are of thick, blocky form, and of brilliant, glossy scarlet. Grow 4 to 5 inches broad at top and are of equal length. Flesh is extremely mild and unusually thick; makes an excellent salad sliced and served like tomatoes. Pkt., 10c; oz., $65 \mathrm{c} ; 1 / 4$ Ib., $\$ 1.75$, postpaid.

LONG RED CAYENNE.-Cone-shaped red pods. Used for salice and pickles. Pkt., $10 \mathrm{c}$; oz., $40 \mathrm{c} ; \mathrm{l} / 4 \mathrm{lb} ., \$ 1.50$, postpaid.

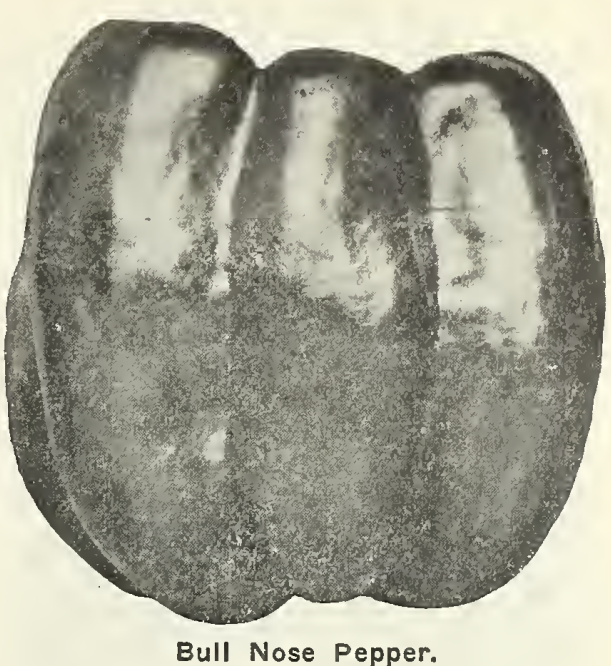

RUBY KING.--Large and handsome. Mild flavor. Ruby red color. Can be sliced for salad or for stuffing or minced pickles. Pkt., 10c; oz., 50c; 1/4 lb., \$1.75, postpaid.

RED CHILI.-A late variety used in the manufacture of pepper sauce. The bright rich red pods are about 2 inches long, $1 / 3$ to $1 / 2$ inch in diameter at the base, tapering to a sharp point, and exceedingly pungent when ripe. Requires a long, warm season. The plants should be started quite early in hot beds. Pkt., 10c; oz., 50c; 1/4 1b., \$1.75, postpaid.

\section{PARSLEY}

Culture.-Is easily grown, only it takes several weeks to come up, hence ground where it is sown is often covered with weeds or dug over with the belief that seed is no good. Seed may be soaked several hours in warm water before sowing, which hasteng germl. nation Sow early in spring in rows a foot apart. Can be used to border beds, making a pretty effect. One ounce will sow a 150-foot row. Plants can be taken up in fall and put in pots or boxes in a sunny window, and will continue to furnish leaves throughout the winter.

DOUBLE CURLED.-An excellent variety for garnishing. Pkt., 10c; oz., 20c; 1/4 lb., 40c; 1 lb., $\$ 1.50$, postpaid.

CHAMPION MOSS CURLED. - Leaves beautifully curled and mossy. Pkt., 10c; oz., 20c; 1/4 Ib., 35c; 1 Ib., $\$ 1.50$, postpaid.

\section{PEANUTS}

TENNESSEE RED.-(28 pounds to the bushel.) Smallpodded variety; similar to Spanish, except that the pods are longer, sometimes containing 5 to 6 peas crowded together; peas dull red in color. This variety is well adapted for stock feeding, but does not sell on the market owing to the color and quality of the peas. Lb., 30c; 3 lbs.a $80 \mathrm{c}$, postpaid. Write for quantity prices.

MAMMOTH JUMBO.--This variety grows to an aston. ishing size. The plants make compact bushes about 18 inches high, with heavy, erect stalks and large leaves. The giant nuts have thick. heavy-ribbed shells. Lb., 30c; 3 Ibs., $80 \mathrm{c}$, postpaid. Write for prices in quantities.

SPANISH PEANUT.-In addition to their value for growing for the nuts, these are very largely used in the South as a forage and fattening crop for hogs and other stock. They are early to mature, very productive, and in the far South, where they can be planted during March and April, two crops can be made in one year, the second crop being planted early in July, the tops making a hay crop and the nuts a grain crop. This variety frequently yields 60 bushels of marketable peanuts and two tons of hay per acre. 28 pounds to the bushel. Lb., 30c; 3 Ibs., $80 \mathrm{c}$, postpaid. 


\section{PUMPKIN}

Culture.-Pumplíns will grow almost anywhere, but rejoice in rich soll. In many varieties the size and weight depend almost wholly on culture and fertility of the land. Many Pumpkins are exceptionally good for pies; other sorts are fit only for feeding livestock. Plant in hills $8 \times 8$ feet. Use $1 / 4$ pound for 75 hills; 3 to with

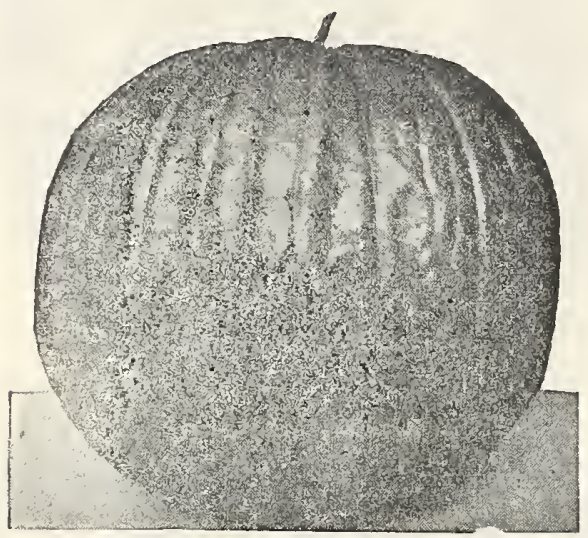

Connecticut Field.

CONNECTICUT FIELD.-One of the best for field culture: can be grown with corn. Is largely used for stock Peeding. A deep rich yellow color. Pkt., 10c; oz., 15c; 1/4 Ib., 30c; 1 lb., $75 \mathrm{c}$; 10 ibs., $\$ 6.00$, postpaid.

CUSHAW.-A prolific variety; large size, frequently weighing 60 pounds and over; color, white striped and mottled with greell. Pkt., 10c; oz., 15c; 1/4 lb., 40c; 1 lb., $\$ 1.50$, postpaid.

MAMMOTH.-A French variety, which grows to an immense size, often weighing over 100 pounds. Fruit is either long or round, but generally flattened at both ends; skin pale green; marked with deeper bands and marbling. Pkt., 10c; oz., 15c; 1/4 lb., 35c; 1 lb., $\$ 1.10$, postpaid.

TENNESSEE SWEET POTATO.-Pear-shaped medium-sized Pumpkins, slightly ribbed, or creamy white color and excellent flavor. Pkt., 10c; oz., 15c; 1/4 Ib., 35c; $1 \mathrm{Ib} ., \$ 1.10$, postpaid.

SMALL SUGAR.-Small, round, yellow Pumpkins of excellent quality. An abundant yielder, 8 to 10 fruits often srowing on one vine. Pkt., 10c; oz., 15c; 1/4 lb., 40c; $1 \mathrm{lb}$. , $\$ 1.50$, postpaid.

LARGE SWEET CHEESE, OR KENTUCKY FIELD.Very early; large-sized Pumpkins, often measuring 15 inches across top, flat like a cheese and very productive. It is an excellent keeper and is of the finest flavor. Splendid for the table as well as for stock-feeding; also largely used for canning. The skin is orange red. Pkt., 10c; oz., $15 \mathrm{c} ; 1 / 4 \mathrm{lb}, 30 \mathrm{c} ; 1 \mathrm{lb} ., 75 \mathrm{c}$, postpaid; $10 \mathrm{lbs} ., \$ 6.00$.

JAPANESE PIE.-The flesh is very thick, nearly solid. the seed cavity being very small, usually finegrained, dry and sweet, having much the same taste and appearance of sweet potatoes. They ripen early, keep well, and produce largely. The seeds are peculiarly marked and sculptured in Japanese characters. Pkt., 10c; oz., 15c; 1/4 Ib., $40 \mathrm{c}$; 1 lb., $\$ 1.50$, postpaid.

LARGE YELLOW.--Most extensively used for feeding stock; also used for making pies. Grows to a large size and varies in shape from nearly round or slightly flattened to quite long. Flesh deep, rich yellow, fine-grained, and highly flavored. Is often planted with corn. It is known also as Field Pumpkin. Packet, 10c; ounce, 15c; 1/4 lb., 30c; 1 lb., $\$ 1.00$.

\section{SEED POTATOES NORTHERN GROWN}

Culture.-To secure best results in growing Potatoes, it is necessary to plant as early as the ground can be made ready. Use a rich soil and plant in rows 3 feet apart and the sets 1 foot apart in the rows, A complete Potato fertilizer sown into the rows wlll aid in harvesting the crop at an earlier date, and usually shows an increased yield Some growers who wish to harvest a very oarly crop sprout the potatoes before planting by cutting the potatoes into pleces of desirable size and placing them in a warm light room for three or four weeks before planting in the open ground weather is favorable, the shoots will start out strong and vigorous and as soon as the plants have sent out roots they row rapidly than freshly cut potatoec most rowers use bushels of potatoes to the acre when planting in 3 -foot rows.

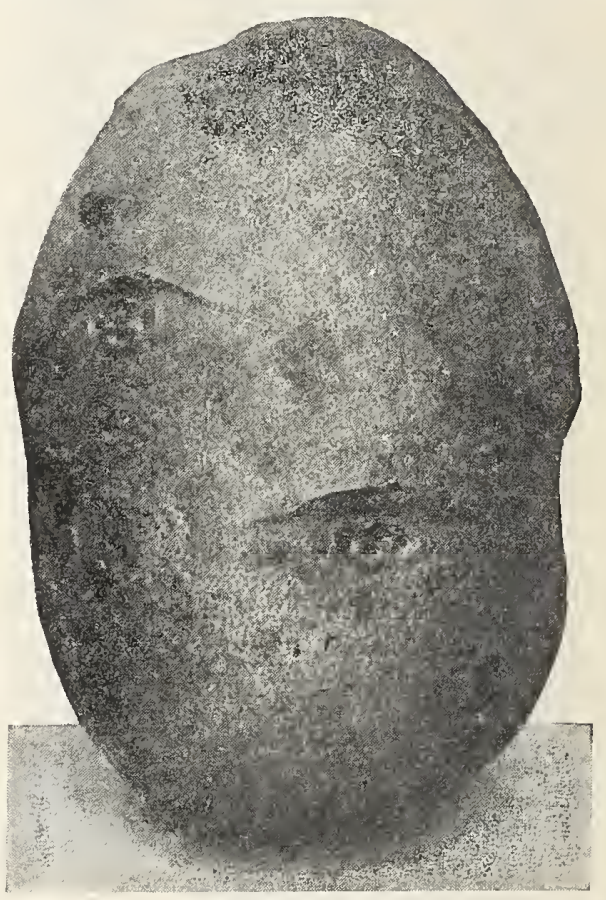

Irish Cobbler.

IRISH COBBLER.-This is a most excellent early variety, maturing good size tubers seven weeks from the time of planting. It has also the remarkable characteristic of producing very few, if any, small potatoes, all the tubers being of marketable size. The vines make short, upright growth, so that the hills may be only a short distance apart. Skin is clear and smooth; flesh is pure white and excellent quality, always cooking mealy.

BLISS TRIUMPH.-Earliest Potato in existence. A handsome variety and wonderfully productive. Tubers are not large, but a fine medium size for early use, round as a ball and a beautiful color. For several years it has been the most popular variety in the South. Not desirable for main crop.

EARLY ROSE.-Great improvement on the old-time Early Rose. A long, red Potato, about ten days later than Triumph. Does better on poor land than most sorts.

EARLY OHIO (RED RIVER STOCK).-Especial attention is called to this strain of Ohios for market purposes. Of good average size, strictly pure, smooth and free from scab and rot, and outyields other early sorts. It is an especial favorite with marketmen, and the most profitable Potato they can grow. Excellent keepers. 


\section{POTATOES-Cont.}

BURBANK.-A very good late variety, fully a month later than the Triumph. It sets heavily and yields a big crop on good land. We do not recommend the planting of this variety on poor soil. We have the genuine seed, procured from a most responsible grower.

On account of market fluctuations, we are unable to name exact prices. We shall be pleased to have you write during the month of January or later and we will then quote prices for prompt or future shipment.

Our Seed Potatoes are hand-picked, high-grade, Northern-grown stock, true to name. Every potato-grower knows that Northern seed is absolutely necessary to plant in this climate to insure early maturity and increased yield.

\section{SWEET POTATO SEEDS AND PLANTS}

SOUTHERN QUEEN.-Very smooth, the tubers hav. ing no veins, or very few. Write for special prices on quantity lots.

CALIFORNIA YAM.-Earliest variety; very productive, yielding as many as 300 barrels per acre on alluvial land. Skin dull white or yellow; flesh white, dry and mealy. Write for special prices on quantity lots.

PUMPKIN YAM.-Excellent in quality and productiveness. Skin and flesh yellow and sweet. Best for home use. Write for special prices on quantity lots.

SWEET POTATO PLANTS.-Bunch Yam, Bunch Yellow Yam, Early Jersey, Nancy Hall, Red Brazilian, Yel. low Yam and Porto Rico. Write for prices.

\section{RADISH}

6 ounces of seed will plant 100 yards of row; 6 pounds to the acre.

Culture--Sow in ground well enriched with rotted manure. Quality depends on quickness of growth. The proper temperature is 40 to 65 degrees. Good ventilation is necessary, if grown under glass. Sow seed $1 / 2$ inch deep in the early spring, in rows 12 to 18 inches apart; for a succession, sow every 10 days. Cultivate Prequentiy. One ounce to 100 feet of drill or 8 to 10 pounds per acre. Thin to 1 inch apart for small varieties and 3 to 4 inches for large varieties Radishes will mature in from 3 to 5 weeks.

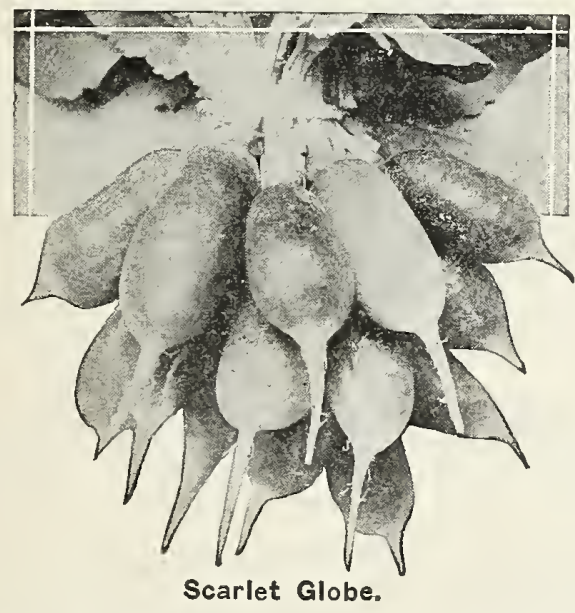

WHITE STRASBURG.-(30 days.) Of handsome, oblong, tapering shape. Both skin and flesh are pure white. The flesh is firm, brittle and tender, and possesses the most desirable character of retaining crispness even when old and large. Excellent for summer use, and withstands severe heat and grows very quickly. Pkt., 10c; oz., 15c; $1 / 4$ Ib., 35c; 1 lb., 90c, postpaid.

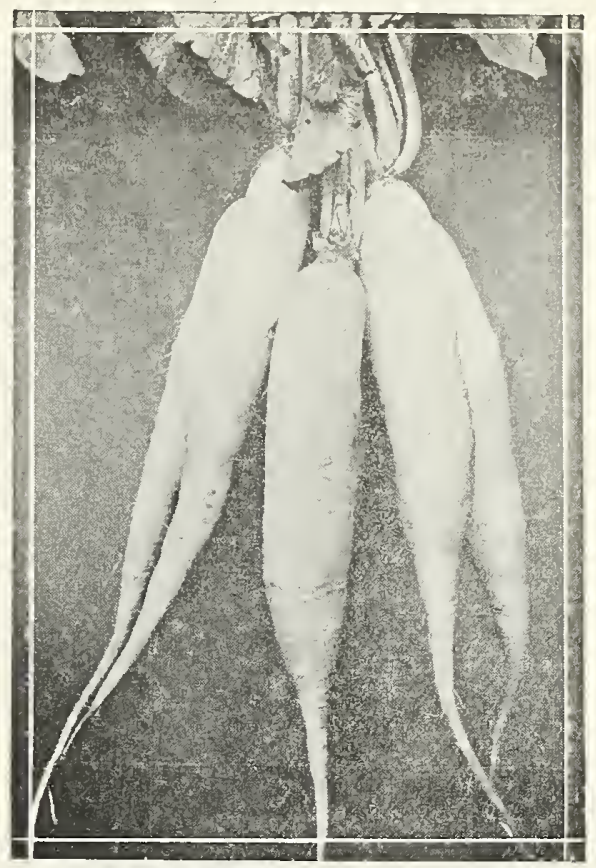

Icicle.

AYRES SCARLET GLOBE.-Twenty days to maturity. A small-leaved variety, well adapted to forcing under glass; root round and carmine colored; early, very attractive and desirable; fine for forcing. Pkt., 10c; oz, $15 c ; 1 / 4$ lb., 35c; 1 lb., 90c, postpaid.

SPARKLER.-A splendid Radish of same type as Scarlet Turnip White Tip, but larger and showing more white, the lower portion being white and upper part deep scarlet. This Radish is not only very showy, but of very finest quality, and sure to become popular with private gardeners as well as growers for market. Pkt., 10c; oz., 15c; $1 / 4$ Ib., 35c; 1 lb., $\$ 1.00$, postpaid.

MARKET GARDENERS' LONG SCARLET.-(35 days.) More largely used perhaps than any other for outdoor planting. Six to 8 inches in length, and possessing all qualities of a fine Radish. Pkt., 10c; oz., 15c; 1/4 lb., 35c; 1 Ib., 90c, postpaid.

ICICLE.-(30 days.) The finest, most delicate. and tenderest of pure white Radishes. About 6 inches in length, clear transparent white, crisp and tender; very attractive on the table and also for the market; ready to pull three weeks after sowing; may be sown as early in spring as soil can be prepared. Remains tender and free from pith for longer period than any other sorts; attractive in appearance and extremely early. Pkt., 10c; oz., 15c; 1/4 Ib., 35c; 1 Ib., 90c, postpaid.

LONG WHITE VIENNA, OR LADY FINGER.- 25 days.) One of the finest and most popular of the long Radishes, growing 6 to 8 inches in length, beautiful in shape; skin and flesh pure white. Pkt., 10c; oz., 15c; $1 / 4$ lb., 35c; 1 lb., 90c, postpaid.

FRENCH BREAKFAST.-(25 days.) A small, handsome variety of very quick growth; $1 / 2$-inch in diameter and 2 inches long. Pkt., 10c; oz., 15c; $1 / 4 \mathrm{lb} ., 35 \mathrm{c} ; 1 \mathrm{lb}, 90 \mathrm{c}$, postpaid. 


\section{RADISH-Cont.}

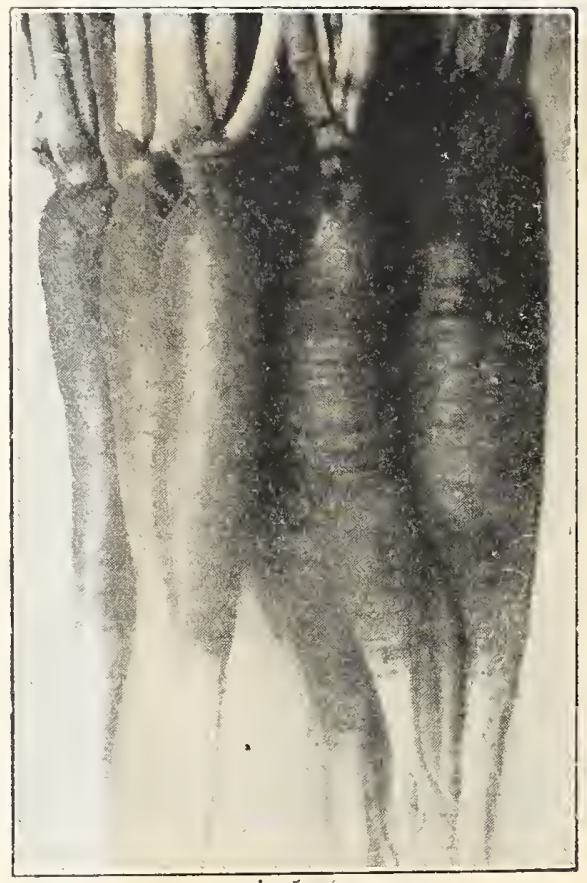

Long Bright Scarlet.

EXTRA EARLY SCARLET TURNIP.-(20 days.) A small, round, red, turnip-shaped Radish, with a small top; of very quick growth. A very early variety, deserving of very general cultivation on account of its crisp and tender qualities. Pkt., 10c; oz., 15c; 1/4 lb., 35c; 1 lb., 90c, postpaid.

EARLY SCARLET TURNIP, WHITE-TIPPED.-(18 days.) A beautiful variety, deep scarlet with white tip. It is very ornamental for table use and is becoming very popular as a market variety. It is of the same size and shape as the Scarlet Turnip variety. Pkt., 10c; oz., 15c; 1/4 Ib., 30c; 1 lb., 75c, postpaid.

HALF-LONG DEEP SCARLET.-(25 days.) Same form as Long Scarlet, but only half as long. Pkt., 10c; oz., $15 \mathrm{c}$; 1/4 Ib., 35c: $1 \mathrm{lb}, 90 \mathrm{c}$, postpaid.

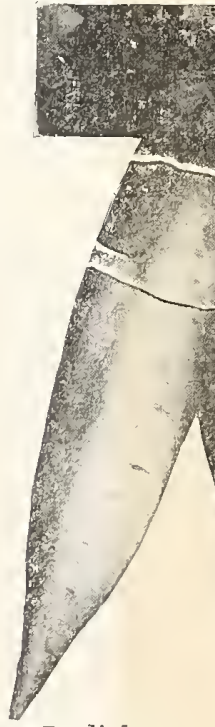

Winter Radishes-

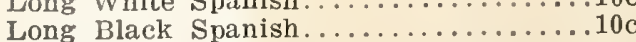

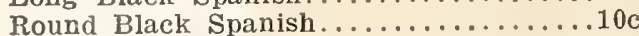

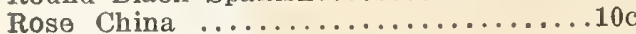

California Mammoth White..............

Rose Turnip Radish................10c

\section{RHUBARB OR PIE PLANT}

Culture.- This is of hardy growth everywhere and one of the first sauce and pie plants of early spring. It is sown either from seeds or propagation of the roots. The soil for Rhubarb should be made extremely rich, using manure every other season. The seed should be sown early in the spring in rows 12 inches apart and 1 inch deep Thin the plants out to stand 6 inches apart and cultirate throughout the summer. In this section of the gouthrest the plants get large enough to use in the fall from seed previous spring. The roots should be planted 3 feat apart in the row and with the crown about 4 inches under the soil one oume of seed will sow 100 feet of drill.

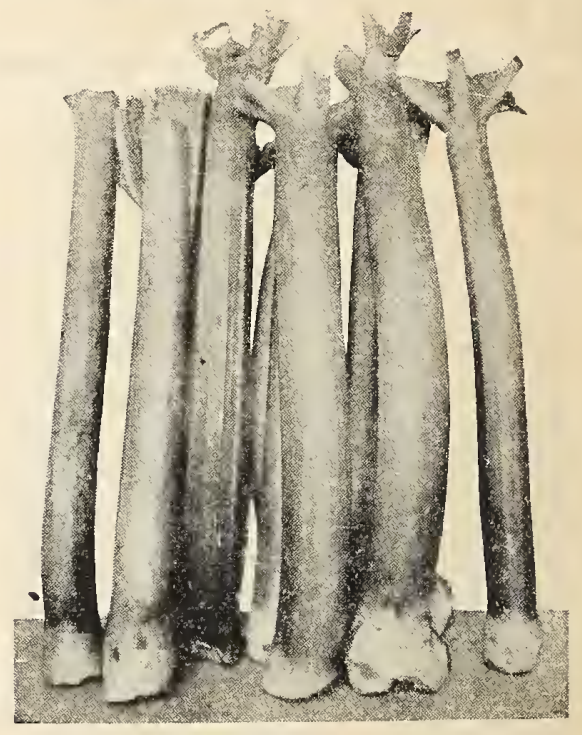

Queen Victoria.

QUEEN VICTORIA.-This is one of the newer $\mathrm{ra-}$ rieties, and in some locations is very popular, being a bright pink. A splendid variety. Pkt., 10c; oz, 20c; $1 / 4$ Ib., 50c; 1 lb., \$1.75, postpaid.

LINNAEUS.-Large and tender. The very linest of all. Pkt., 10c; oz., 20c; $1 / 4$ Ib., 50c; 1 lb., $\$ 1.75$, postpaid.

\section{RHUBARB ROOTS.}

Prices on application.

\section{RUTABAGAS}

Culture.--Rutabagas, Swedish or Russian Turnips, are exteasively grown for a farm crop. The roots are close-grained, hard, and will endure a considerable degree of cold without injury if preserved in a pit or cellar during the winter. Rutabagas are superior to any other vegetable root grown for cattle, horses and sheep. The animals thrive and fatten on rutabagas, carrots and

AMERICAN PURPLE TOP.-A very large, globeshaped Rutabaga, yellow with purple top. Hardy, vigorousgrowing variety of excellent quality for the table and one of the best for stock feed. Pkt., 10c; oz., 15c; I/4 Ib., 35c; 1 Ib., 75c; 5 Ibs., \$3.00, postpaid.

\section{SALSIFY OR VEGETABLE OYSTER}

Culture,-Soil and culture should be the same as for Parsnips, taking pains to make sowings as early as practicable each spring. Salsify is boiled like Parsnips or Carrots, or is half-boiled and grated, then made up into balls which are dipped into batter and fried like oysters. Sow in drills about 18 inches apart, and thin the plants to 3 inches in the row.

MAMMOTH SANDWICH ISLAND.-A new and improved type, producing roots of nearly double the size and weight of the old sort and in every way preferable. Much valued by market gardeners, as it grows stronger and is less inclined to branch. Pkt., 10c; oz., 20c; I/4 Ib., 60c; 1 lb., 


\section{SQUASH}

1 ounce of early varieties will plant about 40 hills; 1 ounce of late varieties will plant about 20 hills; 3 to 4 pounds to acre.

Culture-About the same as Melons. Make the ground very rich. A good sandy loam is best. The Squashes are all tender, and the seed should not be planted until warm weather. Allow $4 \times 4$ feet for tho hills for the bush Squashes and $8 \times 8$ feet or more for tile running varietles. Four plants to the hill; 3 to 4 pounds of seed to the acre. For summer squashes estimate 2 ounces to 100 hills: for winter Squashes, 4 ounces to 100 hills.

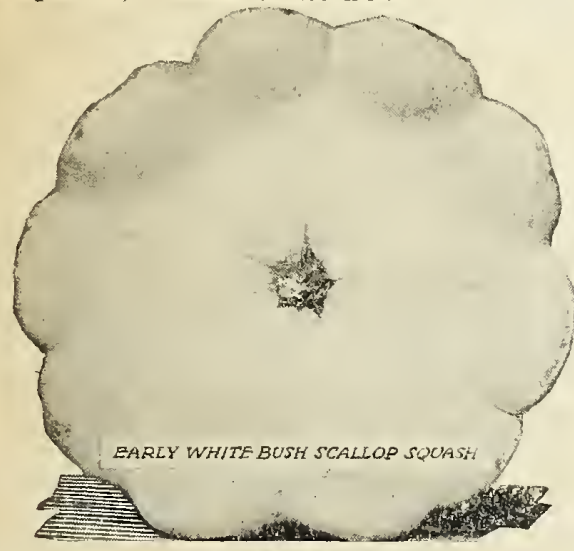

\section{SUMMER VARIETIES}

MAMMOTH WHITE BUSH SCALLOP.-This variety is about twice the size of the White Bush Scallop and much whiter and handsomer. Pkt., 10c; oz., 20c; 1/4 Ib., 50c; 1 Ib., $\$ 1.50$, postpaid.

GOLDEN SUMMER CROOKNECK.-This variety of Summer Crookneck, we find, grows twice as large as the common sort, averaging from 5 to 6 pounds in weight. Pkt., 10c; oz., 20c; 1/4 lb., 50c; 1 lb., \$1.50, postpaid.

THE GRAND SQUASH, DELICIA HUBBARD.-A culinary joy. A Delicia pie or baked Delicia is a very toothsome morsel. Pkt., 10c; oz., 20c; $1 / 4 \mathrm{lb}$., 50c; 1 lb., \$1.75, postpaid.

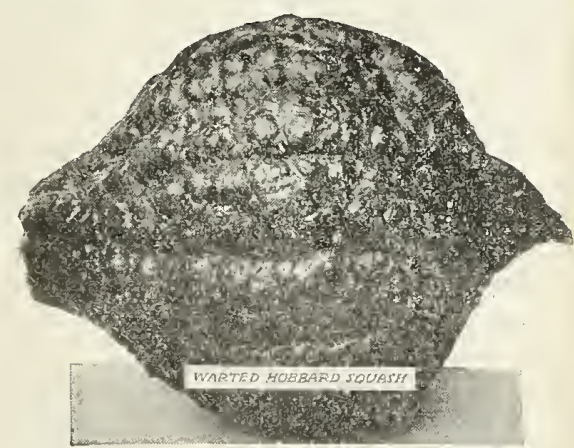

\section{WINTER VARIETIES}

WARTED HUBBARD SQUASH.-This variety is a great favorite with the marketmen. It is very striking in appearance and has been selected for years from exeeptionally large specimens. It crops heavily.- Our crop last season was at the rate of 10 tons per acre. It grows to nearly double the average size of the common Hub. bard. Our strain was obtained from a market gardener famous for his warty Hubbards. It sells in the market better than those having smooth shells. Pkt., 10c; oz., 20c; $1 / 4$ Ib., 50c; $1 \mathrm{lb}$., $\$ 1.30$, postpaid.

FORDHOOK.-Fine grain; very sweet and productive; can be used at any time of their growth; skin very thin; good keeper. Pkt., 10c; oz., 20c; 1/4 lb., 50c; 1 lb., $\$ 1.75$, postpaid.

\section{SPINACH}

1 ounce will sow 150 feet of drill; 1 to $1 \frac{1}{2}$ pounds to the acre.

Culture.-For early spring use, sow seed in August or september in rich soil. Upon approach of cold weather, eover the plants with 3 inches of straw or soft hay, In the spring, when dry, remove litter and plants will be ready for use in a short time. Sow seed 1 inch deep in rows 1 foot apart or broadcast For a succession, sow every two weeks from April to June. Use 1 eunce to 100 feet of drill, 8 to 10 pounds per acre in drills, 15 to 18 ponnds broadcast.

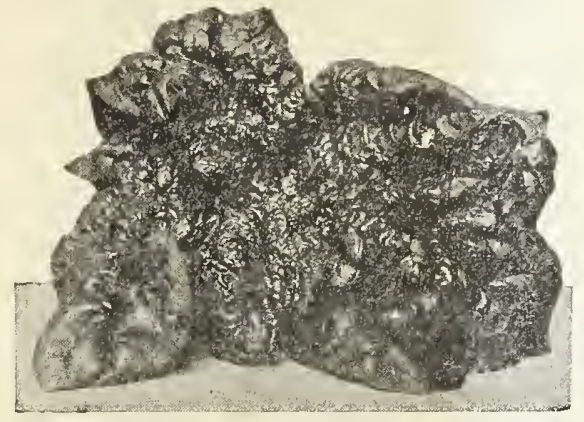

Bloomsdale.

GIANT THICK-LEAVED.-An early variety; very hardy and of good quality. Large, round leaves, nearly smooth, of dark green color; favorite with market gardeners. Oz., 10c; $1 / 4$ lb., 20c; 1 lb., 50c; $10 \mathrm{lbs} . \$ 4.00$, postpaid.

VICTORIA.-Large, very dark green leaves, slightly crimpled. In good condition for market for a long time. A newer variety that is very popular with the truckers. Planted extensively in South. Oz., 10c; $1 / 4 \mathrm{lb} ., 20 \mathrm{c}$; $1 \mathrm{lb}$., 50c, postpaid.

BLOOMSDALE, OR SAVOY-LEAVED.-Of upright growth; leaves curled and crimpled, thick and fleshy. Keeps well after cutting. Suitable for fall sowing. Oz. $10 \mathrm{c} ; \mathrm{I} / 4 \mathrm{lb} ., 20 \mathrm{c} ; 1 \mathrm{lb}$., $40 \mathrm{c}$; $10 \mathrm{lbs}$., $\$ 3.00$, postpaid.

NEW ZEALAND.-A different type of Spinach, suitable for use during the hot weather. Plants grow to a large size, producing an abundance of leaves, tender and of good quality. Oz.o 15c; $1 / 4$ Ib., 35c; 1 Ib., 90c, postpaid.

\section{TURNIP}

1 ounce will sow 150 feet of drill; 2 to 3 pounds to the acre

Culture - The value of Turnips and Rutabagas for feeding stock in fall and winter is not fully appreciated, as they are much liked in fall and winter is not colly a preciated, as they are much They should not be fed, however, in large quantities to milch They should not be fed, however, in disa qubles a we cows, or the flavor of the mils will do dings largely, for we are recommend that farmers increase their sowings largely, for we are sure the crop will prove remunerative for stock feeding as well as for table use when the roots are comparatively small. These Wholesome vegctables are very easily affected in their form and flavor by soil, climate and mode of culture. The Turnip plant is distinguished from the Rutabaga by its rougher leaves, the root early in spring a light, rich or new soil, in drills $1 \frac{1 / 2}{2}$ to 2 feet apart, according to the size of the variety, and cover $1 / 2$ lnch deep, or sow broadcast, but in elther case be sure to have the ground rich and freshly stirred. Thin early and keep free from weeds, so that the young plants will not be checked in growth Any over so that the crowant to the very early portant to get the so that the Turnips may to to fore hot weather causes them to becos the Mldale and Western states, sow for fall and main crop, from the midale of June to the first of for spring sowing. In the field, Turnips are often sown broadcast though in most cases better results are obtalned by dill culture good results from broadcast sowing are often obtained on new and 


\section{TURNIPS-Cont.}

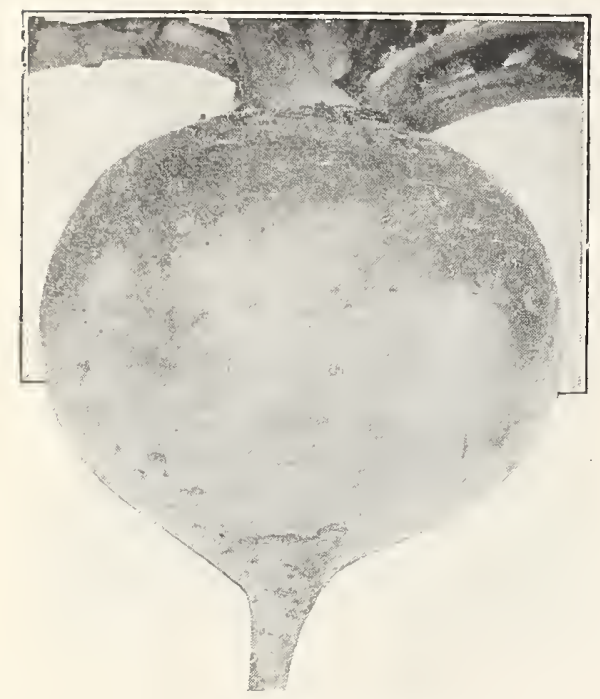

Purple Top White Globe.

PURPLE TOP. WHITE GLOBE.-(65 days.) Large size, rapid growth, unusually attractive. A much heavier producer than the preceding. We confidently recommend it. No sort is its superior. Will produce more tons to the acre than any other sort. Pkt., 10c; oz., 15c; 1/4 Ib., 25c; 1 lb., 60 c; $10 \mathrm{Ibs}_{\text {, }} \$ 6.00$, postpaid.

COW.HORN.-A delicate and good flavored sort, and in favor both in the market and family garden. A distinct feature is its rapid growth. Is pure white, except a dash of green at crown, and is long like the carrot and crooked, hence its name. Pkt., 10c; oz., 15c; 1/4 lb., 30c; $1 \mathrm{lb.}$, $\$ 1.00$, postpaid.

EXTRA EARLY WHITE MILAN.-(45 days.) - Similar to preceding, except skin is pure white, making it desirable for forcing. Pkt., 10c; oz., 20c; $1 / 4$ lb., 30c; 1 lb., $\$ 1.00$, postpaid.

PURPLE TOP (Strap Leaved).-(55 days.) The standard for this section. Superior for early or late planting. Round, flat, good-sized, small top, few leaves. Flesh very fine-grained; flavor good. Pkt., 10c; oz., 15c; $1 / 4 \mathrm{lb}$. , 25c; $1 \mathrm{lb} ., 60 \mathrm{c}$, postpaid.

YELLOW GLOBE.-A round, smooth, light yellow Turnip of medium size. The flesh is crisp, firm, and of very good quality for the table or for stock-feeding. The roots are in best condition for table use when 3 to 4 inches in diameter. This sort keeps well and is a good cropper. Pkt., 10c; oz., 15c; 1/4 lb., 30c; 1 lb., 75c, postpaid.

\section{TOMATOES}

Tomatoes do best on light, warm, not over-rlch soll, and success depends upon securlng a rapid, vigorous and unchecked growth during the early part of the season. Sow In hot-bed or in shallow boxes in the house from 6 to 8 weeks before they can be set out of doors, which is when danger from frost is past; when the plants have four leaves, transplant into shallow boxes or cold-frames, setting them 4 or 5 inches apart; give plenty of alr and endeavor to secure a vigorous but steady and healthy growth, so that at the time of setting in the open ground they will be strong and stocky. Even a sllght check whlle the plants are small will materlally dlminish thelr productlveness.

Set out of doors as soon as danger from frost is over, but before doing sc harden off the plants by gradually exposing thein before aoing se harden olf to the night alr and by the withdrawal of water untll the wood becomes hard and a dark green color. Transplant carefully and cultivate well as long as the vines wlil permit. le to be grown without training, the plants aro usually set varlety.
To insure best results in respect to early ripening, as well as the amount and perfection of frult, it is advisable to traln up an trim the vines, especially if the patch is rather small. When the plants have been properly started and are 6 to 10 lnches high they will begin to throw out branches. Select the largest and most vigorous of these and pinch off all others except thls one and the main stem. Care must be exerclsed not to plnch off the fruiting branches, which as they appear can be distinguished by the buds that are formed very early. In a short time these two remalning branches will become equally vigorous, and as ordinary varieties will grow 4 to 6 feet ligh during the season, they should be securely tied at intervals of about 10 inches to a long stake, preferably 2 inches square, whlch has been securely set in near the root of the vine.

Fruit wlll set to almost any helght desired if all side branches are kept trimmed off at Intervals of a week. By such a method of training and trimming the frults are kept clear from the ground and with free access of sunlight they ripen much earlier; the vitality, otherwise exhausted in superfluous branches and leaves, is utilized in forming fruits of largest size, greatest perfection of shape and best quality. For cultural directions, see books llsted on inside of back cover.

Culture.-This vegetable, under proper cultivation, is wonderfully productive both as to quantity and quality. In this sectlon of the country it is more largely used in canning than any other vegetable and should have a place in every garden. One ounce or seed will produce 1,000 plants. For early use, sow in February or March in hot-beds or boxes, which should be placed near a window. When the seedlings are 2 to 3 inches high, transplant Into 2 or 3 -inch pots or in rows 4 or 5 inches apart, keeping the temperature about 60 degrees. Subsequent transplanting will make the plants strong and hardy. Do

BEAUTY, IMPROVED STRAIN.-A standard Varlets for many years, and is still the favorite main crop Tomato with market gardeners. Medium early, round, very uniform in shape. Skin smooth, crimson with purplish tinge. Flesh solid and of excellent flavor. A splendid Tomato for either home garden or for shipping. Pkt., 10c; oz., 30c; $1 / 4$ Ib., 90c; 1 lb., \$3.25, postpaid.

THE NEW STONE.-The Tomato for the main crop. Choicest seed. We call this the king of the Livingston kinds, which are the best types of large, smooth, solid, "beefy" Tomatoes. If asked to select one main crop market sort, we advise this. Color fine scarlet, stem set high, core small and shallow, so that little is lost when it is taken out of the fruit before slicing. If in doubt, buy the New Stone for market or home use. Pktog 10c; oz, 30 c; $1 / 4$ lb., $75 c$; 1 lb., \$2.50, postpaid.

DWARF STONE.-(100 days.) Fruit like Improved Stone. The strong upright growth allows very close planting. The plants may be set 18 by 24 inches apart and yet produce an abundant crop. Pkt., 10c; oz., 30c; 1/4 lb., 90c; 1 lb., \$3.00, postpaid.

MATCHLESS.-(100 days.) A large, bright red Tomato; very popular in the East. Fruit is large, smooth and symmetrical, ripening well to stem. Flesh is of a rich red color and fine quality. Pkt., 10c; oz., 30c; $1 / 4$ lb., 75c; $1 \mathrm{lb}$., $\$ 2.50$, postpaid.

TRUCKERS' FAVORITE.-(90 days.) Purple-fruited, excellent quality, good size, maintained until late fall. Fruits are smooth, solid, and flesh is finest color. Unexcelled for slicing or cooking. Plants thrifty, free from rust or blight, and bear until kilied by frost. Pkt., 10c; oz., $30 c$; $1 / 4$ Ib., 90c; 1 lb., $\$ 3.25$, postpaid.

ACME.-(100 days.) An old-time popular variety, having at all times given entire satisfaction. Round, smooth, purple. Pkt., 10c; oz., 30c; $1 / 4 \mathrm{lb} ., 90 \mathrm{c} ; 1 \mathrm{lb} ., \$ 3.25$, postpaid. 


\section{TOMATOES-Cont.}

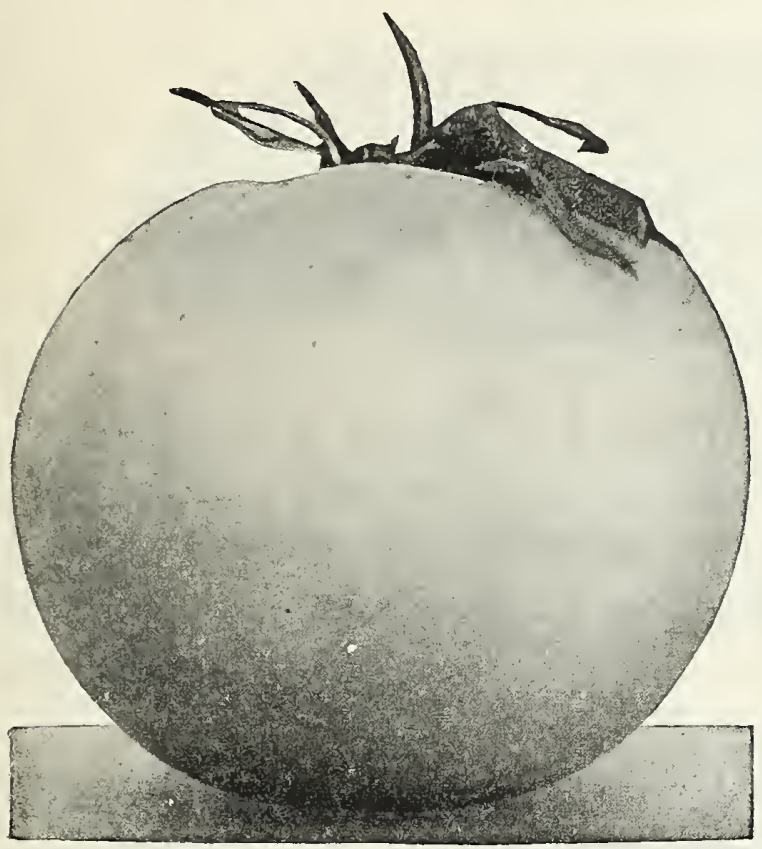

Improved New Stone.

JOHN BAER.-Largest fruited, smoothest and finest in quality of the extra early Tomatoes. Vines short, vigorous and enormously productive. They ripen a larger crop in the early part of fruiting season than any other extra early variety. Fruits globular, uniform and smooth; freo from wrinkled, cracked fruits. Color is a bright scarlet. Fruits have no hard core; small seed cells, and practically all meat of mild and sweet flavor. Pkt., 10c; oz., 30c; 1/4 Ib., 90c; 1 lb., \$3.25, postpaid.

SPARKS' EARLIANA.-(90 days.) Fruit of large size, handsome shape and color; in solidity and quality equal to any; has proven very remunerative to growers for market; grows in clusters of 5 to 8 fruits; ripens clear to the stem and does not crack. Pkt., 10c; oz., 40c; 1/4 lb., 90c; $1 \mathrm{lb}$. $\$ 3.25$, postpaid.

FAVORITE (Livingston's).-Ripens evenly and early; very prolific; good flavor; few seeds; flesh sound. Pkt. $10 \mathrm{c}$; oz., 30c; $1 / 4 \mathrm{lb} ., 90 \mathrm{c}$; 1 lb., $\$ 3.25$, postpaid.

BONNY BEST.-An early and productive variety. Fruits are round, somewhat flattened at stem end, and are produced in abundarice. The color is scarlet, and it is a good forcing Tomato. Pkt., 10c; oz., 30c; 1/4 lb., 75c; $1 \mathrm{lb}$. $\$ 2.50$, postpaid.

GOLDEN QUEEN (Queen of the Yellows).-(100 days.) Solid, smooth, large in size, and ripens early. Makes a handsome, rich preserve. This Tomato should be grown in every home garden. Its flavor is better and more delicate than that of the red varieties, the fles. grained and very tender. Try it. Pkt., 10c; oz., 30c; $1 / 4$ Ib., 90c; 1 lb., $\$ 3.25$, postpaid.

JUNE PINK.-(90 days.) A purple-pink selection from Earliana. The fruit is smooth and the plant a good yielder. Pkt., 10c; oz., 30c; 1/4 lb., 90c; 1 lb., $\$ 3.25$, postpaid.

PONDEROSA.-(120 days.) Purplish-pink Tomato of the largest size. Very meaty, few seeds, and free from acid. Ripens mid-season. Pkt., 10c; oz., 40c; 1/4 lb., \$1.25; 1 lb., $\$ 4.00$, postpaid.

DWARF CHAMPION.-Sometimes sold as the "Tree Tomato." A second early or main crop, purplish pink variety; desirable where garden space is limited. Vines are about 2 feet high, vigorous, upright, compact. Fruits medium-sized, smooth and of very good quality. Our stock is a superior strain with more even, smoother fruit than the original. Pkt., $10 \mathrm{c}$; oz., $35 \mathrm{c} ; 1 / 4$ ib., $\$ 1.10$; 1 lb., $\$ 4.00$, postpaid.

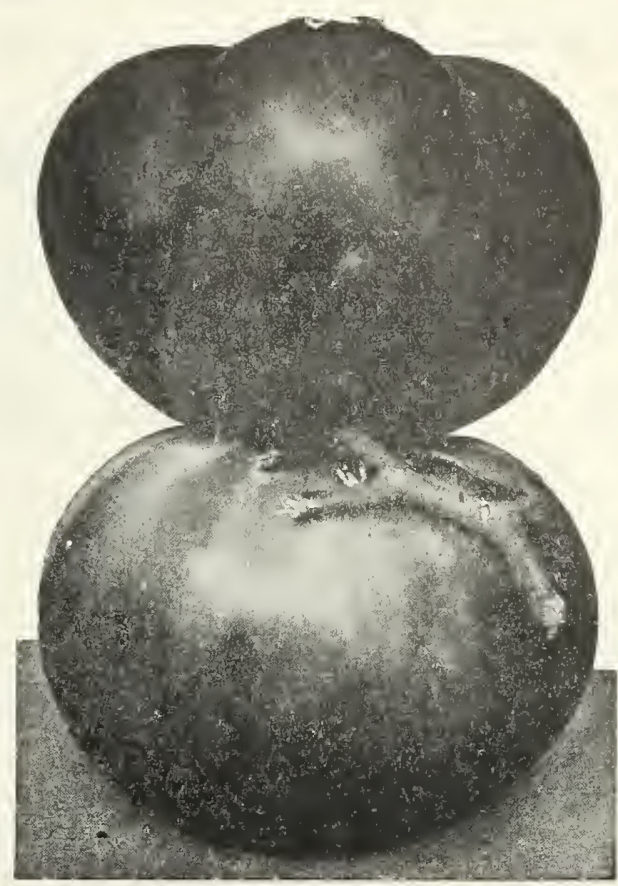

Dwarf Champion.

PEACH.-For preserving or table decoration; fruits resemble a peach in shape and size and the color is light terra cotta red, with a delicate bloom. Flesh is tender and good flavor. Pkt., 10c; oz., 40c; $1 / 4 \mathrm{lb}$. $\$ 1.25 ; 1 \mathrm{lb}$., $\$ 4.00$, postpaid.

\section{SMALL-FRUITED TOMATOES}

Very delicious for preserving. Vines immensely productive.

YELLOW PEAR.-Fruits similar to the Red Pear, but of' rich, clear, yellow color, and quite distinct from the va. riety sometimes sold under this name. Pkt., 10c; oz., 30c; $1 / 4$ Ib., $\$ 1.00$, postpaid.

YELLOW PLUM.-Fruits plum-shaped, of clear, deep yellow color; flesh yellow and finely flavored. Esteemed for preserves. Pkt., 10c; oz., 30c; $1 / 4$ lb., $\$ 1.00$, postpaid.

RED CHERRY.--Fruits small, about $5 / 8$-inch in diam. eter, perfectly round and smooth. Fine for pickles and preserves Pkt., 10c; oz., 30c; 1/4 Ib., \$1.00, postpaid.

YELLOW CHERRY.-Differs from Red Cherry in color only. Pkt., 10c; oz., 30c; I/4 lb., \$1.00, postpaid.

YELLOW HUSK, OR GROUND CHERRY.-Very sweet, mild flavor; used for preserves. Vines low and spreading. Fruits small, about 1/2-inch in diameter, enclosed in a loose husk. The seed we offer is that of the true Yellow Ground Cherry. Pkt., 10c; oz., 35c; 1/4 Ib., $\$ 1.10$, postpaid.

\section{TOBACCO}

HAVANA.-From pure Cuban grown seed. When grown in this country commands a high price for cigar stock. Pkt., 10c.; oz., 40c, postpaid.

MISSOURI BROAD LEAF.-Extensively grown in Kansas and Missouri; the large broad leaves are used for the wrappers. Pkt., 10c.; oz., 40c, postpaid.

WHITE BURLEY.--Largely used for the manufacture of cigars, as the leaf of this variety readily absorbs a large quantity of manufacturing material. Pkt., 10c; oz., $40 \mathrm{c}$, postpaid.

\section{VEGETABLE PLANTS}

EARLY CABBAGE PLANTS.-For delivery in Apri and May.

SW.EET POTATO PLANTS.-All the leading varieties. TOMATO PLANTS.-Ready in May and June. 


\section{FIELD SEED SECTION \\ BRYSON AYRES FIELD AND GRASS SEEDS}

ARE

Recleaned, Tested and Certified

At the time this Catalog goes to press prices are so unsettled that it is impossible to print all of them. Write Us for Prices.

Always Buy THE BEST.

\section{SEED CORN}

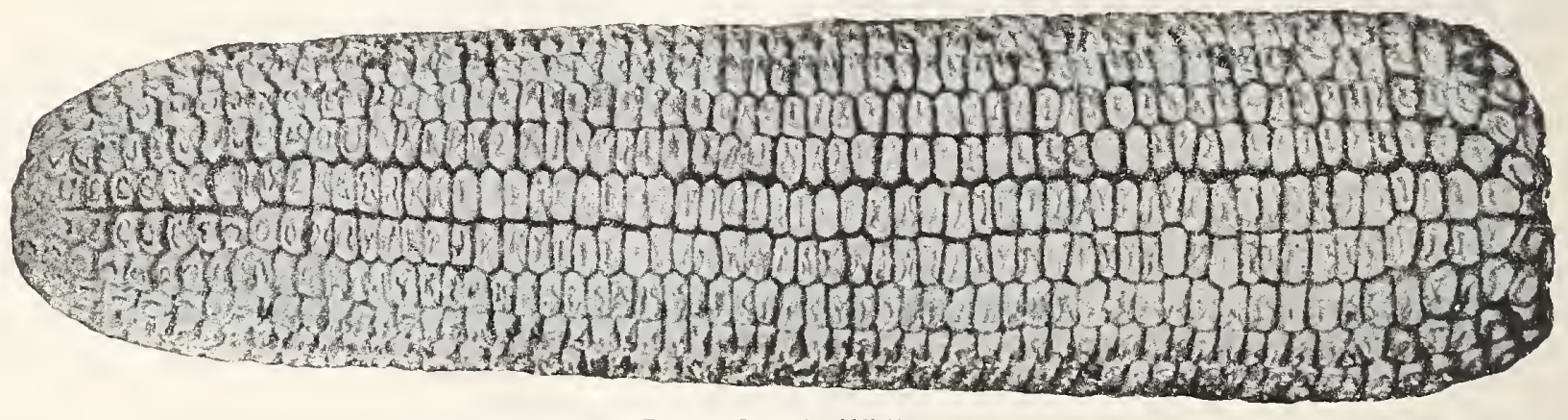

Boone County White.

We have been able to secure seed Corn of excellent quality, and the test shows high germination. We will be able to furnish the following varieties of good quality until our stock is exhausted. Prices subject to change without notice.

\section{SELECTED SEED CORN}

\section{HAND-PICKED, NUBBED AND GRADED}

IMPROVED GOLDEN BEAUTY.-(110 days.) We know of no other variety that will give better satisfaction than the big, handsome Golden Beauty. It is the largest grained Dent Coln in cultivation. Ear is perfect in shape with 10 or 14 rows of golden yəllow grains; cob small. and is sure to please every farmer who grows it. The heaviest cropper we have handled. Prices on application.

REID'S YELLOW DENT.-(110 days.) Thoroughbred, pedioreed, carefully selected stock. During the past tive or six years this variety has come rapidly to the front and now occupies a prominent position in all lists. It is of handsome shape and color, and largely grown for exhibiting a lairs, Corn shows, and is used in many Corn schools as a standard for judging. We have selected the choicest ears. so that we are sure our seed cannot fail to please the most particular. Handsome yellow color. smooth, deep-grained, and kermels packed very closely on cob, giving it an appearance of great solidity. Matures in about 115 days. Prices on application.

IOWA SILVER MINE.-Iowa Silver Mine is standard. It is well and favorably known. A remarkable drouthresister, and under adverse conditions seems to pull through and make a crop where other varieties fail. Silver Mine is deep-grained, pure white, rough topped, with a small white cob. Ears from 9 to 12 inches long, with 16 to 20 rows of pure white kernels, solidly set on ears; well filled out at butt and tip. This Corn is a drouth-resister, niaturis in hot climates where early drouths are frequent. stalks medium height, very leafy, with broad blad əs, frecuently bearing two ears weighing 1 to $1 \frac{1 / 2}{2}$ pounds each. Iowa Silver Mine has taken as many sweepstakes and first premiums as any Corn. The pure-bred Silver Mine is a safe clop anywhere in the corn belt and in all the Southern States, including Missouri Kansas, Oklahoma, Texas, Arkansas, Louisiana, Mississippi, Alabama, Georgia, Tennessee, Kentucky and Virginia. Matures in 100 days.

IOWA GOLD MINE.-Is not a large-Corn, but the best thing we know of for meaium early. We offer the pure strain Gold Mine, and recommend it. With the expert corn larmers. Gold Mine is known as medium earlyhetween the 110-day and the extra early sorts that mature in 85 days. It is, however, a great producer and sure cropper. Ears are medium and symmetrical. Color, bright golden yellow. The grain is deep, and the cob is small; for this ieason it dries out quickly, producing 62 to 63 pounds of shelled corn to 70 pounds of ears. S'alks make exifllent silage or fodder. Iowa Gold Mine will grow in nearly every State and is specially recommended for the Western corn belt. Throughout the Eastern States, where climate dces not demand an extra early variety, it is very popular. Tried all over the South with nothing but best results. 


\section{SEED CORN-Cont.}

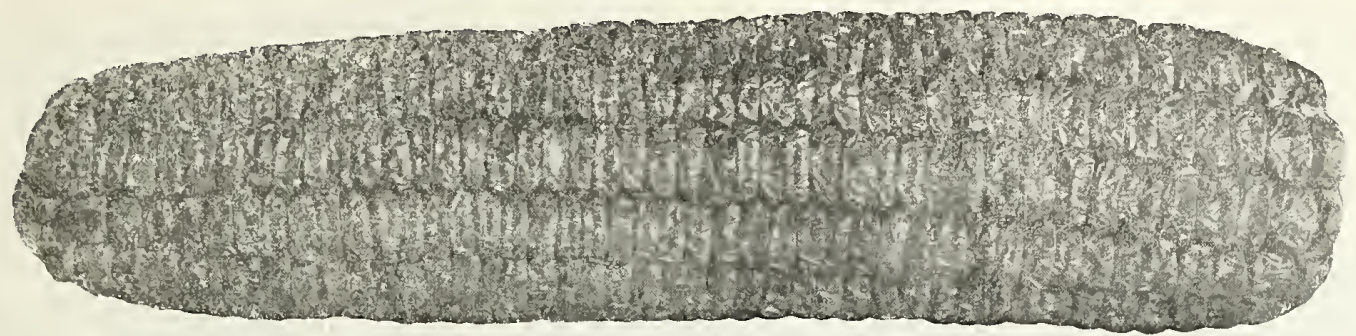

lowa Silver Mine.

BLOODY BUTCHER.-Color, deep cherry-red with white cap, generally 14 rows of pure red, white cap corn on a small cob. Long, slender ears. 8 to 10 inches. Stalks medium height, fairly heavy, grains always dented and sometimes rough. As White Cap Red Butcher will mature in 90 days, it is planted for husking crop throughout the North Corn Belt as far up as St. Paul, Minn. The same conditions exist throughout the Middle West and on east to New York and the New England States. Finds many friends for late planting in Iowa, Illinois and Eastern Nebraska. Great favorite in Missouri, Kansas, Okiahoma and Texas for early feeding. Matures in 85 to 90 days.

WHITE PEARL.-An extra early pure white variety of the Dent family; very productive and exceedingly heavy, maturing in 5 to 90 days from the time of planting. The grains are extra deep and wide, two of which will more than span the cob. which is small; also largely used for roasting-ears. Prices on application.

ST. CHARLES RED.COB WHITE.-Pure white corn with red cob, ears large, moderately rough, deep grain. Stalks grow leafy and heavy and will produce enormous yields of Corn for husking crop or for silage. It is a native of St. Charles County, Missouri, best adapted to the Southern States for a husking corn and is in great demand in the Eastern and Northern States for ensilage and fodder purposes.
BOONE COUNTY WHITE.-(110 to 120 days $)$ A very large white Coln, something like Silver Mine, but larger and later in maturing. It is a native standard variety in Illinois. Boone County is peculiarly suited to all the Southern States, as it ripens earliel than the native Corn and will not be forced ahead too rapidly, owing to its slow-growing tendencies. Ears well filled out at both ends, cylindrical, 9 to 11 inches long, averaging twenty rows, some eighteen and twenty-two. Grain very deep, a little rough. Cobs white, of medium size. Boone County is a show Corn, and has carried off many premiums offered at Corn contests, State and county fairs. For the southern half of Iowa and localities that do not lie farther north; southern Illinois and Nabraska. Oklahoma, Missouri, eastern Kansas, Texas, Arkansas, Louisiana, Miss'ssippi, Alabama, Georgia, Tennessee, Kentucky and Virginia.

\section{GRADING, GERMINATION, YIELD}

You want varieties that will give you big yields. This is the most important of all. What we all aim at is $\mathbf{1 0 0}$ bushels to the acre of shelled corn; mighty f'ew of us strike it, but we are working that way. In our seed business we have always put yield ahead of fine points and have tried to send out varieties that will give the farmers big yields.

\section{ALFALFA}

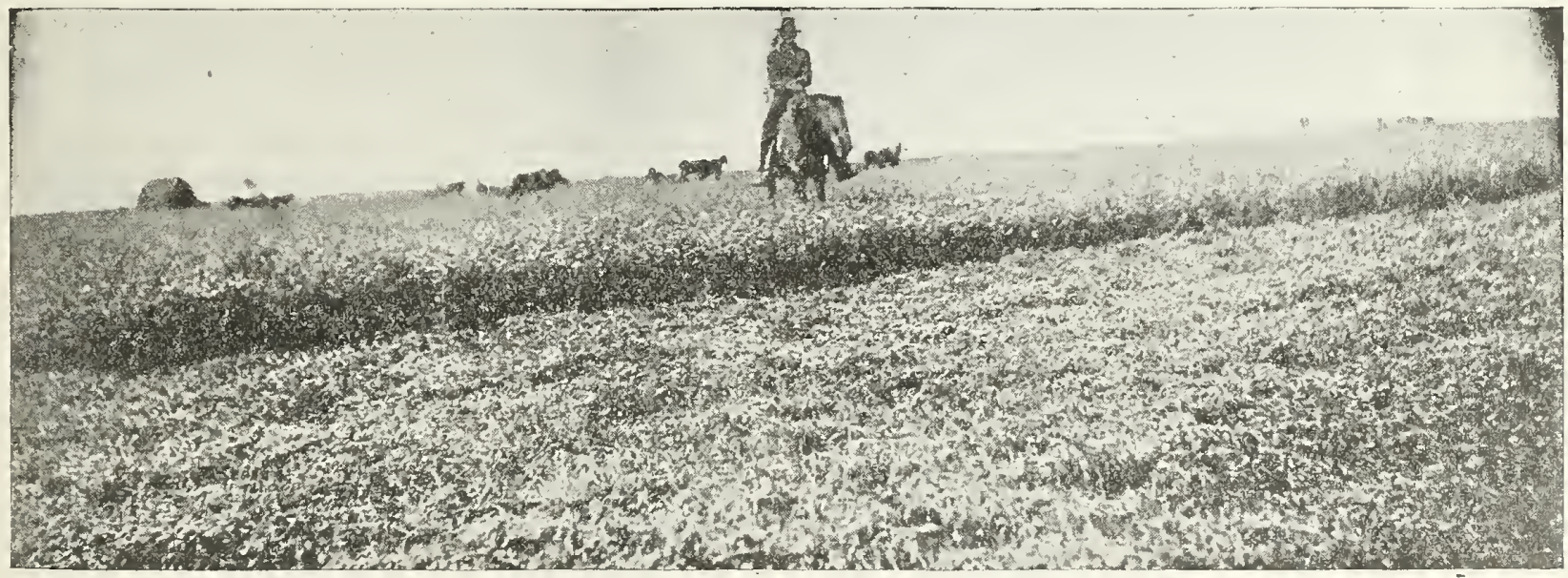

CERTIFIED ALFALFA SEED.

Pursuant to our policy of protecting the customer wherever possible, we have gone to the expense of having our seed tested for germination and purity and of marking each sack with a tag or certificate showing results of such test and giving purity and germination of seed contained therein. This we guarantee to be correct.

\section{THE BEST OF ALL PLANTS FOR HAY AND PASTURE}

Altalfa, the most valuable forage plant ever discovered, was first tound in Asia, but its present wide distribution throughout the world indicates a remarkable adaptability to various sulls and climates.

It is now the principal leguminous forage crop of all continents of the world and is one of the staple crops in our country. By experimenting, varieties have been produced which do well in the coolest climates of the North.

Alfalfa is a soil-builder, and not a soil-destroyer. The roots often reach the length of 15 feet. This penetration not only loosens the soil for the roots of the next crop, but brings to the surface the phosphorus and potash stored below. 


\section{ALFALFA-Cont.}

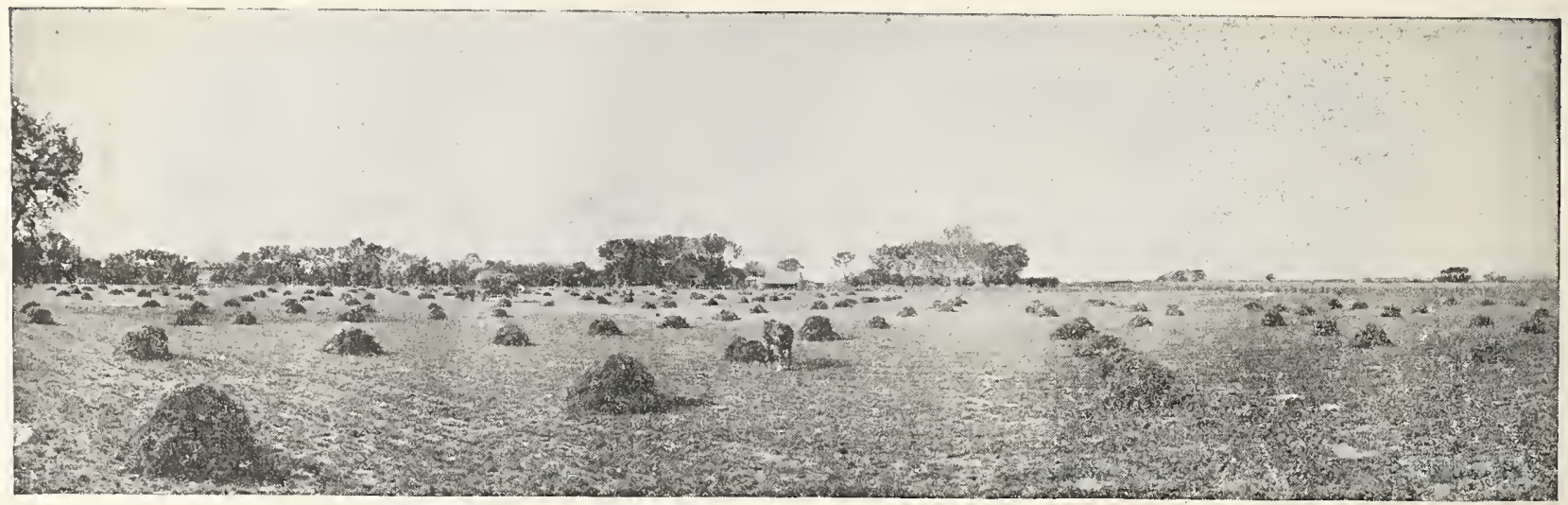

A few general rules can be laid down for Alfalfa culture, as different conditions require different methods. It is advisable, therefore, to do a great deal of experimenting in untried districts. Small tracts should first be planted in order to ascertain the correct method.

In selecting the field which is to be seeded the following conditions should be carefully considered: (1) Depth and texture of the soil; (2) drainage; (3) fertility; (4) the need of lime; (5) seed bed; freedom from weeds. These are so vastly important that if any are neglected the growing of Alfalfa may be rendered impossible.

Soil: Alfalta gives best results on deep, loose, open, friable soils. Drainage: Alfalf'a does not do well where the water is nearer than six feet to the surface. Drained bottom lands are good, but land slightly rolling, or level and well drained are best. Fertility: Alfalfa, being a legume, is able to add nitrates to the soil through the nodules formed by bacteria within its roots. Since large yields of Alfalfa draw heavily on the other elements of soil fertility, it naturally requires the richest and best drained soil on the farm.

LIME.-Acid soil will not permit Alfalfa to grow. This is often the case where corn or wheat has been raised for many years. A simple test for determining acidity in soil is to make a deep cut in the ground with a knife, pushing the earth apart, then place a piece of litmus paper (procurable at any drug store) into the opening and press the earth together. Leave the paper a few hours. If it changes from blue to red it is proof of acidity. Lime is then needed to sweeten the acid soil. If agricultural lime san be bought at $\$ 3.00$ per ton, it will pay to sprinkle from 1 to 2 tors per acre on the land before planting Alfalfa.

SEED BED.-The success in starting Alfalf'a depends largely upon the condition of the seed bed. A good seed bed should be firm, well settled, not too hard, and with the surface soil mellow and finely pulverized as deep as the seed is to be sown. A bed of this character allows free movement of the capillary water from the sub-soil, furnishing the plant at the same time with a proper root hold. Moisture is not available to the young plant in a deep, loose sub-soil, for a loose sub-soil prevents the rise of capillary water. Besides being mellow and firm at planting time, the seed bed should contain ample moisture and available plant food the longer time elapsing between preparation of the seed bed and planting, the better. If conditions are such that the planting must be done soon after plowing, be sure to roll the land well and firm it thoroughly. "Between plowing and planting, work the ground sufficiently to kill the weeds off and keep the moisture up. To have an ideal seed bed have a firm base, loose top, no weeds, and moisture well up.

PLANTING.-If broadcasting, three ways: With a wheel-barrow seeder, an end-gate seeder, or by hand.
If any of the these three ways are used, harrow lightly immediately following planting. If the ground is disced lightly before planting, leaving it a little rough, the seed will be easier covered than if the surface is smooth.

Drilling is best, as it distributes the seed evenly, putting them where needed, causing less waste and putting them at a uniform depth. Do not place the seed too deep in the soil, $3 / 4$ to 1 inch is usually sufficient.

TIME OF PLANTING.-Spring and fall planting are equally successful, a great deal depending on the season and climatic conditions. When spring seeding is practical we advise sowing as early as possible, after frost is out of the ground, as there is less danger from freezing out than irom losing a stand due to warm, dry weather or choking cut with weeds.

SEED.-When buying Alfalfa, you want the best and purest seed obtainable. Cheap grades are apt to contain Sweet Clover, Yellow Trefoil, Burr Clover, Dodder, etc. We handle the best hardy, non-irrigated stock, for it has much stronger vitality than irrigated or foreign seed and gives better results.

Ayres Certified Alfalfa ..............Per 100 lbs., $\$ 18.00$

Ayres Fancy Alfalfa ............................. 100 lbs., 17.00

Ayres Choice Alfalfa ...............Per 100 lbs., 16.00

Ayres Prime Alfalfa ................Per 100 lbs., 14.00

NURSE CROPS.-If a nurse crop is used, Barley, Wheat or Rye are much better than Oats, as Oats require too much water and give too much shade. In using a nurse crop, the Alfalfa seed and the grain should be sown separately and not mixed before seeding.

GRIMM ALFALFA.-It is positively the hardiest Alfalfa seed on the market. The strong branching roots of Grimm prevent winter killing as in common ordinary Alfalfa. These same rcots which grow in time 6 to 20 feet in length and as thick as a man's wrist provide drought resistance and unusual productiveness.

Again these great roots make humus when ploughed into the soil, and this humus conserves moisture, thus preparing the soil for whatever subsequent crop might call for it. Grimm Alfalfa plants are extraordinary soil fertilizers. We offer to send a free sample to you and to any friends of yours who you think would be interested in the purchase of Grimm Alfalfa Seed.

Price, $50 \mathrm{c}$ per pound, $\$ 45.00$ per 100 pounds.

\section{FACTS ABOUT ALFALFA.}

There is no State in the Union in which Alfalfa cannot be successfully grown.

Alfalfa is more valuable than Clover, since, wherever it flourishes, it yields more per acre and is worth far more as a feed. 


\section{ALFALFA-Cont.}

Alfalfa produces from 3 to 7 tons of hay to the acre. It has as much protein as wheat bran.

Three hundred and sixty stalks have been grown from one seed

It does not exhaust the soil; it enriches the soil.

It will grow 3 to 5 crops a year.

Alfalfa in money value is worth 45 per cent more than other Clovers and 60 per cent more than Timothy.

Ten milk cows can be fed on less than two acres by soiling.

One acre will pasture 20 pigs for six months.
Three pounds a day makes a full feed for fattening lainbs.

Four to five pounds makes full feed for fattening aged slieep.

Slleep fed oll Alfalfa will gain from 8 to 15 pounds in 75 days and will double with small grain ration added.

Lambs wintered on Alfalfa will produce one to two pounds more wool than when on the ranch.

Fed to dairy cows, Alfalfa maintains the flow of milk equal to June grass. It can be chopped fine with corn meal. Such a mixture is worth more a pound than the original corn meal.

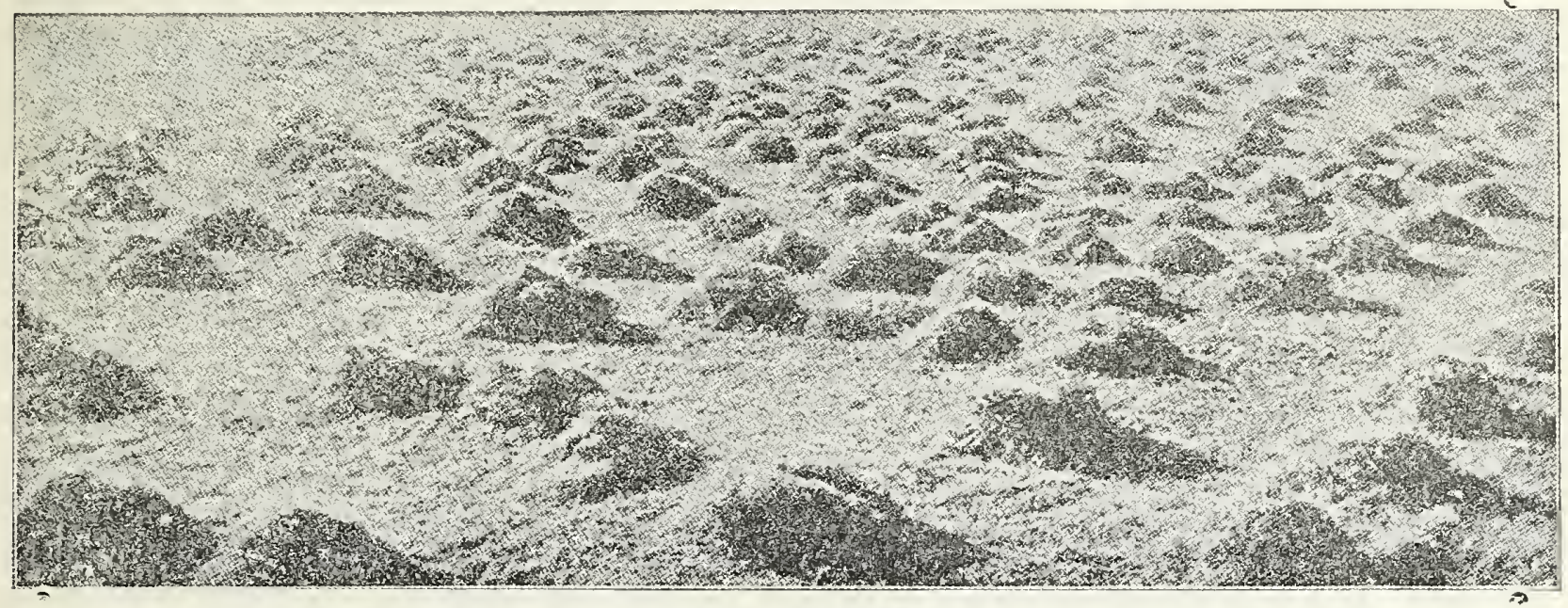

\section{CLOVER}

SWEET CLOVER.-(White Blossom.) This is the variety most commonly found and the one in greatest demand. It is the variety that is grown so extensively as a cultivated crop and the one so much in demand. The White Blossom Sweet Clover is destined to become the most important of the legumes and will add millions to the wealth of the farmers of this country.

The great value of the plant is now realized, as it excels Alfalfa as a pasture crop and will produce more tons of hay per acre than Alfalfa, the hay being fully equal in feed value. Its greatest value as a money crop is unquestionably in the seed crop. Sweet Clover will produce a heavy crop of hay the first year; the second year you can harvest a crop of hay and the second crop may be gathered for seed, as it does not make a seed crop until the second year. When harvesting the crop for seed, a sufficient quantity will shatter so as to reseed the ground without having to sow again. This should be remembered, and we would recommend the harvesting of Sweet Clover for seed, as it is a heavy producer of seed. It is not unusual to harvest from 4 to 6 bushels of seed to the acre; yields of as high as 11 bushels have been reported.

This variety grows on all soils and conditions, so no one can go wrong in sowing it. Nothing better for wornout land. clay soils, wet bottom land, or, in fact, any land. No matter whether the poorest soil or the best-wet or dry-it will make the best paying crop.

When seeding, the ouality of your seed should be the first consideration, and we cannot emphasize this point too much. Beware of cheap seed, as it is apt to contain noxious weeds. Scarified seed, $\$ 11.00$ per $100 \mathrm{lbs}$.

YELLOW BLOSSOM BIENNIAL.-(Melilotus Officinal.) This variety is very similar to the White Blossom, but it does not grow quite so large and for this reason many prefer it for hay and pasture. If you wish Sweet Clover for fertilizing, the White Blossom is considered superior, but if you wish to grow for hay, we do not hesitate to recommend this variety to you.
YELLOW BLOSSOM ANNUAL.-(Melilotus Indica.) This is a variety of Sweet Clover, growing from 15 to 20 inches high, which is being used by many who wish something for cuck results. It comes on earlier and makes a full crop the îrst season. It is a very valuable plant for the purpose of sowing with grain in the spring, as it will make a splendid growth of humus, restores nitrogen to the soil, and can be plowed under in the early fall, thus being equal or superior to a heavy coat of barnyard manure or some hioh-priced fertilizer. It is used by many preparatory to sowing Alfalfa when they wish to have it follow a grain crop. You sow the seed in the spring and right after harvest the crop is plowed under, making the ground in splendid condition for Alfalfa.

ALSIKE CLOVER.-Known as Swedish Clover. Increasing in popularity very rapidly as its great worth is being recognized. This is a wonderful Clover, adapted to all kinds of soil where grass will grow, but especially adapted to moist, wet soil, where it is subject to overflow; providing thie water does not stand on it too long at a time. There are thousands of acres of land scattered over the country that should be in Alsike Clover. Wet land, where not much but weeds, wire grass or swamp grass is growing, would produce a wealth of fine grass that is valuable for both pasture and hay.

Alsike Clover is not such a coarse plant as the Mammoth or Common Red Clover; more the nature of White Clover except that it is much more erect, grows even better than Common Clover. The blossoms are purple-very similar to the hlossoms of Alfalfa in size and color. It makes splendid hay for stock of all kinds and is especially fine for horse feed.

This is a splendid year to use Alsike, as it is much cheaper to sow than Common Clover. The seed is about the size of Timothy seed and goes much further. You will save money by using Alsike Clover, and will be delighted with results. Yov should buy Alsike Clover freely this season. $\$ 20.00$ per 100 lbs. 


\section{CLOVER - Cont.}

WHITE DUTCH CLOVER.-Commonly known as Clover, that makes such good pasture and is so valuable for lawns. It is the hardiest of all Clovers, and accommodates itself to all manner of soils. Will endure the extreme heat and dryness of summer better than Blne Grass. Will not tramp out. Keeps soil from washing. It requires less to sow than others, as 5 or 6 pounds per acre is sufficient. $30 \mathrm{c}$ per lb.

JAPAN CLOVER.-(Lespedeza.) This is particularly suited for waste lands, woodland pastures; giows fairly well on poor soils and spreads rapidly, and when once established usurps wild growths, and will in many cases even subdue broom sedge. It is not, however, a pest, and can be gotten rid of by plowing it up, and is excellent as a iertilizer. Highly recommended for cover crop in orchards and used extensively for this purpose. Japan Clover is particularly valuable for pastures on such sjils as described, and where the soil is good yields a fair quantity of good hay. It is relished by cattle, is nutritious and fat tening: To obtain a stand, it is only necessary to scatter the seed broadcast in the spring during Mlarch and Apri at the rate of about 10 pounds per acre. Harrowing the land over before the seed is sown, when it can be done, is, of course, better, though this is not imperative.
MEDIUM RED CLOVER.-This is regarded as the most valuable of the Clover family, and is largely used for pasturage and hay. Clover adds greatly to the f'ertility of the land on which it is grown. It does not exhaust the soil, but enriches it. It makes two crops each year. The first is usually cut when it is in blossom, for hay. The last crop may be harvested for seed, cut for hay, or plowed under to add fertility to the soil. For hay, it is particularly well adapted for sowing with Orehard and Tall Neadow Grass, as it ripens at the same time, and sowing these three grasses together will give larger yields and better quality hay than sowing either alone. It is also lal'gely sown with other grasses, both for hay and pasturage. When sown by itself, sow 8 to 10 pounds to the acre, either in the spring or fall. Certified, $\$ 24.00$ per $100 \mathrm{lbs}$.

MAMMOTH RED CLOVER.-This grows much taller than Viedium Red, with larger, leafier sta.ks. It makes good hay, if cut soon enough, although it has a coalser stem than the Medium Red. Being a rank grower, it is $\checkmark \rightarrow r y$ valuable for fartilizing purposas. The fol:age and flower are darker than the Medium Red, and it ripens later and makes only one crop. Espe ially valuable on light. sandy soil. Certified, $\$ 26.00$ per 100 lbs.

\section{SOY OR SOJA BEAN}

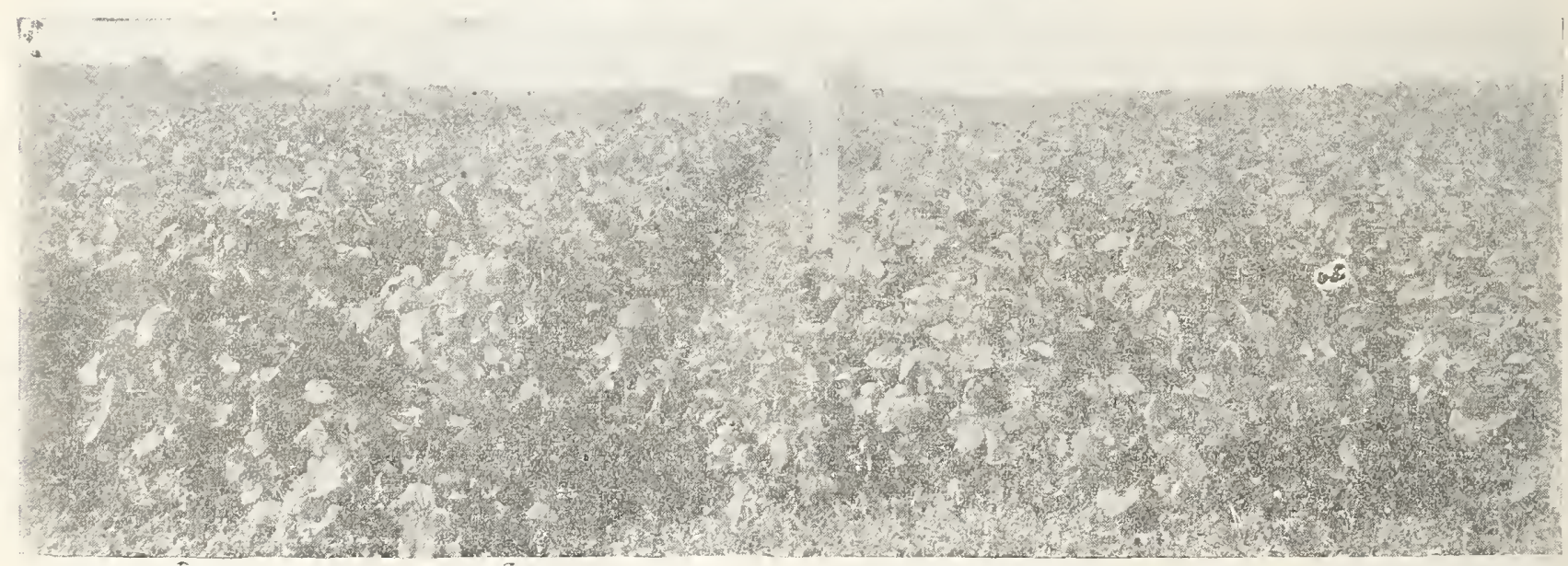

\section{Write lor prices.}

Ask for prices.

Soy Beans may be utilized either as a soiling crop, pasture crop, hay crop, or grown for seed. As a soiling crop for cows, no clop surpasses them for producing a high yield of milk. Hogs turned into a patch cf Soy Beans as the Beans are commencing to form will make a phenomenal growth. The Soy Beans will produce und $2 l^{\prime}$ farolable conditions 12 to 13 tons of fresh fodder per acre containing large amounts of crude protein and fat. which makes an excellent forage to mix with çrn fodder or other forage plant high in carbohydrate, but low in protein.

Jou should consider its value as a grain as no other grain crop causes as high a $p \geqslant r$ cent of protein and fat, analyzing richer than oil meal, nearly ectual to co ton seed ineal, and far more palatable and digestable than either. its value as a forage crop shows by chemizrl analysis test that it compares very favorably with Alfalfa.

culture.-Soy Beans do best on a medium soil, but wíl make splendid growth on poor soil Grutnd should be we!l propared and planted alout the same time as Corn. If crop is desired fo hay, sow broadcast or drill about $I$ hushel to the acre and to sow a shed.crop plant in rows the same as Corn with a planter every inches, using about / hushel of seed to an fere. planting after rain crop houlte lant between corn rows at the last cultivation.

The ti ..e of harvesting depends upon the use to be made of the crop. If you wish to cut for hay, this should be done when the pors are quite well developed for best feeding value, while stock relish the hay mole when cut at an earlier stage. Poss best time to harvest would be when the pods are forming.

For a seed crop, it is hect to wait unil mrst of the leaves have fallen and then cut when the dew is on, bunch with a self-rake and rave in bunches until dry enough to shock up.
ITO SAN SOJAS.-An old variety, and the best real early Bean. Matures probably f'ive days earlier than Mongol; is well adapted to Michigan and other States in that latitude: Beans medium size, yellow. It branches reasonably well, stands erect and is a reasonably good yielder. Sow about 20 pollnds to acre.

MAMMOTH YELLOW SOJAS.-Largest growing and most popular of Soja Beans for forage purposes. A little later in maturity than other kinds, but makes larger yields, both of forage and səed. Especially valuable for this section and further south. 'This Mammoth Yellow is the most desirable variety to plant.

MEDIUM EARLY YELLOW.-This variety is popular for growing throughout the Central States, as it matures earlier than the Mammoth Yellow. It does not produce as much folage, but it produces a heavy crop of Beans, which niakes it desirable.

BLACK EBONY.-Black Soy Beans are becoming very popular and produce wonderful crops of nutritious Beans.

\section{COW PEAS}

Asle for quantity prices.

EVERYBODY'S CLOVER-FOOD FOR MAN AND BEAST.

Cow Peas are too familial to every man and woman to need description. The character of growth in the many different varieties is quite varied. They are usually planted any time after corn-planting season is over, up to the first of August. Some varieties are highly esteemed for garden use, others for making hay and enriching the land. 


\section{COW PEAS-Cont.}

BLACKEYES.-Early, quick maturing bunch variety that fruits abundantly on black clay soils or sandy soils alike. Especially desirable for table use.

NEW ERA, WILD GOOSE, ETC.-Early, quick maturing sorts, having bluish speckled Beans. Several different kinds are sold under these names, but all are popular.

WHIP.POOR-WILL. - A well-known variety, witl brownish speckled seed, ncted for its vigor and usefulness as a seed, hay crop, or soil-renovator. Most popular of all Cow Peas. $\$ 3.60$ per bushel.

CLAY.-Vines grow long and leafy; late maturing. Especially desirable for hay and soil work.

MIXED COW PEAS.--Many farmers planting Cow Peas solely for soil improwement prefer to sow a mixture of varieties.

\section{MILLET}

Millet is an important and nutritious hay and forage crol-splendid for dairy cows young stock and sheep, and yields heavily. It is easily cured, and its rapid growth makes it a splendid "catch" crop. Sow broadcast at the rate of 1 bushel to the acre. It matures from six to eight weeis after seeding: can be planted from April until August, but not too early. Cut while in bloom. before the seed hardens in the head. Two crops can be grown on the same land.

GERMAN MILLET OR GOLdEN MILLET. True Southern-growll seed. In the North Millet is sown almost altogether for hay and for that purpose Southern-grown seed is much the $b$ sst. It grows taller than does that from Northern seed and that means more hay. It is finer than that from Northern seed and that means better liay. Millet seed preduced in the North, even from Southern seed, becomes what we call Common Millet. Not oaly does the plant change in character, becoming coar'ser and much more dwarf. but the seed itself shows a change and is readily distinguished by thos 3 experienced in handling it. Golden Millet is very sweet and palatable and when fed to dairy cows produces a large amount of milk. On gocd rich soil it grows 4 to 5 feet high. It is very tender if cut at the right stage, which is when it is in full bloom. About $3 / 4$ of a bushel of seed is sown to the acre. A good yield is 3 to 5 tons of hay to the acre. $\$ 3.00$ per $100 \mathrm{lbs}$.

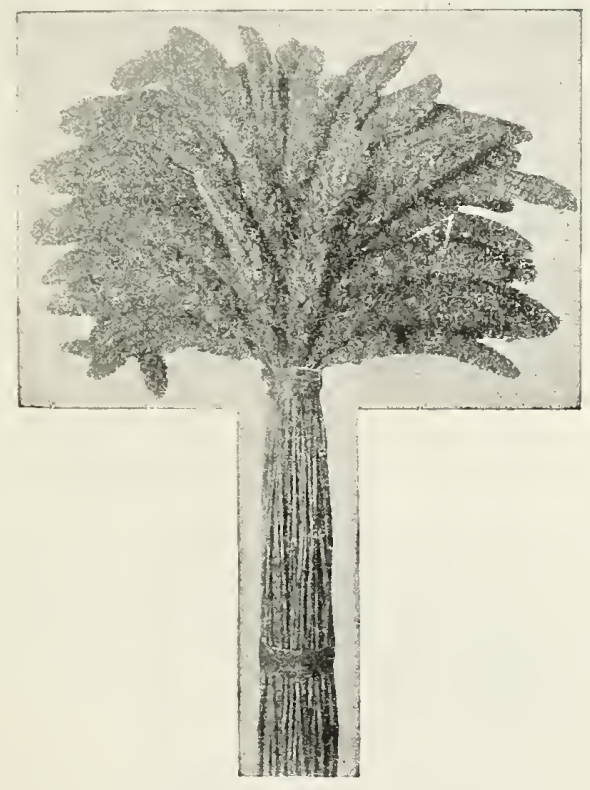

COMMON MILLET.-This is similar to the Liberty Millet, except that the heads are smaller and the seeds lighter colored, and it is earlier. $\$ 2.50$ per $100 \mathrm{lbs}$.
HOG MILLET.-Grows from 3 to 6 feet tall; produces large heads and larger seeds than any other Millet. Seeds contain a high percentage of oil and have a higher feeding value per pound than our common Corm. This plant al ways produces a heavy head of seed. The seeds furnish the best of all foods for poultry. It has produced as high as 75 bushels of seed per acre. One great feature of this Millet is that the seed ripens before the straw, so that it may be cut and bound as wheat or oats inreslied and a mice green crop of hay put up, while the seed may be housed and fed separatıly as grain. This plant is an annual, and, like other Millets, must be planted each season. By beginning to sow with early corn-planting and keeping up sowing the first of every month till September 1 we can have fine green foliage for stock all summer.

Liberty Millet.-Well known for its quick growth and large heads when growing with an abundance of moisture and sunshine. For seed, sow 6 to 15 pounds pel acre; for hay, sow 20 to 40 pounds per acre. $\$ 2.50$ per $100 \mathrm{lbs}$.

\section{TIMOTHY}

Of hay grasses, Timothy is one of the most popular, nutritious and salable. On clay or heavy loams, lowlands $\mathrm{ol}^{\circ}$ in mountainous districts, provided there is an abundance of moisture, it produces the very best results. On sandy or light loamy ground it does not do so well as Orchard, Tall Meadow Oat, or Red Top Grass. If grazed or cut too close the stand of Timothy will be seriously injured, besides it does not form as good grazing as many other grasses. The yield of hay is from $1 \frac{1}{2}$ to 3 tons per acre. Timothy reouires good land to make good crops. It does not root as deeply and is not considered as much of an implover as other grasses consequently should not be sown on land deficient in liumus or vegetable matter. nor on soils of a light or sandy nature. Clovers grow well with Timsthy and aid it by supplying nitrogen. Timothy alone, 1 peck (11 pounds) to the acre; or with Clover, 10 pounds Timothy and 6 pounds Clover; a splendid mixture is $\&$ pounds Timothy, 6 pounds Clover (either Mammoth Clover or Alsike Clover preferred, as they mature at the same time as Timothy), 6 pounds Fancy Red Top, 1/2 bushel Meadow Fescue. Together these will produce most excellent hay, also nutritious and abundant pasture in good loamv clay or low-ground soils: 8 pounds Timothy and 6 pounds Clover when sown together. Certified, $\$ 4.00$ per bu.

\section{RED TOP OR HERD GRASS}

A valuable grass for moist, rich soils, where it thrives very luxuriantly. It is a good variety to sow with Timothy and Clover for meadow or pasture and is more permanent than either of the two. It should be fed close, as if it is allowed to grow up to seed, the cattle dislike it. On good soil it grows about 2 feet high; on poor, gravelly land about half that height. It has been grown successfully even on alkali land, where otler grasses failed. Red Top is commonly known as Herd Grass, and should be more extensively grown. especially in combination with other grasses. Red Top is especially adapted to growing on wet soil, having an impervious subsoil. Because of this climate, it is exceptionally well adapted to land inclined to be wet, or on low, marshy places. It also grows on dry land. $30 \mathrm{c}$ per $\mathrm{Ib}$.

\section{VETCH, THE SOIL BUILDER}

Vetch will grow where many Clovers will not grow. Especially is this true of alkali soil, where Vetch do's well. It succeeds especially well on sandy soils, and will pay large returns on any soil that is well drained. Vetch is not suitable for wheat lands or acid soils, but a crop of Vetch could be grown on almost every farm in any community and prove to be a big-paying proposition.

Vetches are a very hardy crop. Especially is this true of Hairy Vetch, as it withstands the severe winters of Michigan. New York and even the New England States. 


\section{VETCH-Cont.}

This factor alone makes it desirable in sections where hay and pasture crops often winter-kill. This crop when sown in the fall will grow rapidly, the rate depending somewhat on the season and soil conditions. It will re main green and give excellent pasturage after nearly all the plants have been killed by the frost, and it will be the first thing green in the spring. Bear in mind that Vetch is adapted to the whole United States of America.

TIME OF SEEDING.-The time of seeding differs in sections, but there is scarcely a point in our country where fall sowing does not give excellent results.

VALUE OF VETCH FOR FEEDING.-You know the crops we compare it with. Note how near to wheat bran it is in feeding value and how it excels in fertilizing. Vetch is one of the richest legumes in feeding value, and has become known as the King of Soil-Builders.

Vetch is sown in the spring or fall in the Central and Northern States and only in the fall in the Southern States. Spring sowing in the Southern States of'tentimes is not successful, on account of the heat. Hairy Vetch is a valuable plant, and if you wish to use for hay, sow with rye or some similar crop to support the vines; for pasture it can be sown alone. The amount of seed used varies from 25 to 35 pounds to the acre.

SPRING VETCH.-A very productive and highly nutritious plant; excellent to cut green for soiling or made into hay; splendid feed for cattle and stock of all kinds. We find an ever increasing demand for Spring Vetch, as more is being used for plowing under. It has the advantage over peas in that it makes a greater growth of vine, while, as the seed is much snialler, a less quantity is required to plant an acre. Furthermore, this plant is adapted to the North much better and is unquestionably superior on this account.

Spring Vetch should be sown only in the spring, as it is not hardy, so as to permit fall sowing, except in the extreme South. Price, $\$ 10.00$ per 100 pounds.

SAND OR WINTER VETCH.-A very valuable forage plant. It is very hardy, is valuable as a winter cover crop to prevent leaching and for forage and fertilizing purposes. It is an annual, but resows itself, and will come up year after year on the same ground. It succeeds well on nearly all soils and thrives surprisingly on poor, light land and will endure extremes of drouth, heat and cold. It improves the soil. It may be sown either in the spring or fall with about half a bushel of rye or oats for support. It grows rapidly, and is particularly valuable in sections where Clover does not thrive. When sown in April or May it can be cut in July, the second growth affording excellent pasture during the summer. The yield of green fodder is from 12 to 20 tons an acre. Price, $\$ 18.00$ per $160 \mathrm{lbs}$.

\section{GRASS MIXTURE FOR HAY AND PASTURE}

All authorities agree that for pasture and hay the best results are obtained from the use of grass se ds in spocies. The reasons are obvious. First, a number of species will insure a much denser growth than the same kind of seeds of one or two spacies and prove less exhausting to the soil, since they live to a large extent on the same constituents; second, seasons that affect some grasses adversely are favorable to other sorts, so that with a mixture failure is practically impossible, provided the seed is good. Our grass seeds secure the highest germination, and mixtures are based on an appreciation of the requirements of the different soils for which they are intended.

A mixture of grasses produces a better meadow and makes a better permanent pasture than a combination of Timothy and Clover. While Timothy is a splendid grass, and Clover the foundation of all successful farming, neither are permanent nor well adapted to pasturing. Both are affected by drouth and frost, making it necessary to resow every few years. Timothy and Clover last but a few years, while a good permanent pasture will last ten or even twenty years.
For every different kind and condition of soil there are a number of grasses especially suitable. Some kinds do bcst on high ground, and flourish in dry weather, others on low ground and wlere there is plenty of moisture. Some varieties are so early in maturing, others so late, that if a mixture of grasses is used there will be no time from early spring until snow covers the ground that one species or another will not be at its best.

Meadows sown with carefully selected Grass-Clover mixtures will occupy the ground more closely and will produce a better quality as well as a larger yield of hay and subsequent fall pasturage than can be secured from fields sown with Timothy and Clover alone.

CLOVER, ALSIKE AND TIMOTHY.-This mixture combines the distinct features of our other two famous mixtures. It contains the same proportion of Timothy and divides the Clovers about equally. In this mixture you secure the fine-stemnied, palatable Alsike, which makes. the finest hay, and the Red Clover, which grows a little longer, forming a hay rich in Clover or protein food. The same rate of around 12 pounds to the acre, and we consider it superior in many ways to Timothy alone.

MEADOW MIXTURE.-For both hay and permanent pasture. It affords enormous crops of hay of the finest quality and highest feeding value, and after this has been cut it furnishes continuous and abundant pasturage of the richest and most nutritious character until winter sets in. It will stand for years and may be used either for pasturage exclusively or hay and pasturage, as varying conditions may suggest. It contains Mammoth Red. Medium. Red, Alsike, and White Clover, Alfalfa, Timothy, Kentucky Blue Grass, Meadow Fescue and Perennial Rye Grass. Owing to the deep rooting and spreading character of many of the varieties employed, fields sown with this mixture will, during periods of drouth, look fresh and green, while other meadows and pastures are dry and burned. We recommend at least 30 pounds to the acre.

METHOD OF SOWING.--Amount of seed depends on nature of soil and location. Some prefer sowing grass seed alone. We think a crop of Spring Wheat, Barley or Oats can be profitably used as a nurse crop. Do not seed too heavily with grain.

\section{ENGLISH BLUE GRASS OR MEADOW FESCUE}

Next to Kentucky or Southwestern Iowa Blue Grass. it is very popular and its growth is increasing each year. Especially adapted for a permanent pasture. One of the standard English grasses, growing from 2 to 3 feet high, but not in tufts like Orchard Grass. The most nutritious of all grasses. A most pərsistent grower, resists drouth and cold winters, makes good hay, and cattle thrive on it, whether in a green or dry state. Succeeds even on poor soil, and as roots penetrate deeply (from 12 to 15 inches), it takes extremely dry weather to affect it. Will stand more freezing, and yields an abundant crop of seed. A profitable seed crop, and in some parts hundreds of carloads are threshed yearly, and a quantity of the seed shipned to Europe. It will succeed on any good corn land, bilt thrives best on rich heavy soil-even gumbo land will make a gocd crop. Sowing may be done in the spring or fall and is usually done with a wheat drill. The ground should be well preparcd by plowing some time before sowing and allowed to settle. The seed should be put as near the surface as possible. One bushel ( 24 pounds) of seed is required to sow an acre. The crop is ready for harvesting in July and is usually cut with the self-binder and threshed from the shock. The straw makes winter forage. and the aftermath furnishes good pasture the rest of the summer.

Meadow Fescue is a very valuable grass to have on your farm. It is rich in feeding value, and does not winterkill very easily. It is adapted to all kinds of soils, excepting those that are too dry, and we urge you to at least try a small acreage of it this year. $\$ 25.00$ per $100 \mathrm{lbs}$. 


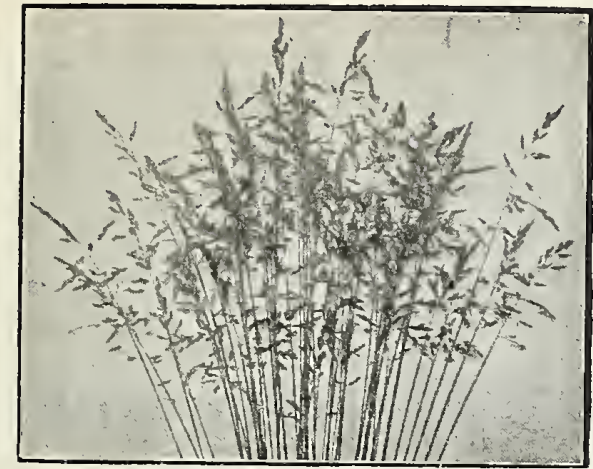

English Blue Grass.

\section{ORCHARD GRASS}

There is much to be said about the desirability of Orchard Grass, and while it does not meet every requirement, it has advantages for many sections and for many fields. No other grass will give equal results. The demand for Orchard Grass the past few years has been gradually increasing, as the farm journals and experimental stations have been advertising the use of it and explaining its virtues. It is an exceptionally valuable grass for pasture or hay land and, on account of its earliness, especially valuable for a permanent pasture. It furnishes green grass very early in the spring and until late in the fall. When closely cropped, it grows up very quickly and is ready for grazing in ten or twelve days. When grown for hay, more than one crop can be obtained, in one season, and when only one crop is cut the aftergrowth is very heavy and gives splendid and rich pasture till late in the fall. The roots extending to a great depth, it will stand drouth better than most other grasses and is very hardy. It grows in tufts and is therefore best sown with other grasses. It is well suited for shady places, such as orchards and groves. It grows on all kinds of land, but does best on deep, rich, sandy loam or clay soils. Height, 3 feet. It flowers in June about the same time as Red Clover and is often grown with it. It blooms three weeks earlier than Timothy. $\$ 20$ to $\$ 25$ per 100 lbs.

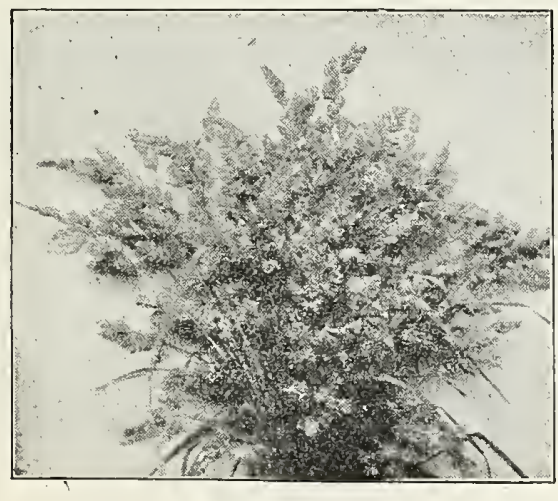

Orchard Grass.
RYE

WINTER RYE.--Experience with drouth and winterkilling during the past two years has led farmers to seek a crop which would be proof against these. Winter Rye is, without doubt, a crop which will endure the most punishment from extremes of heat, cold and drouth of any crop now grown.

Much can be said in favor of Rye as a forage crop. On account of its rapid growth it affords excellent pasture, both fall and spring. It can be pastured very late in the spring and then produces a very good crop of grain. Ask for prices.

\section{RYE AND VETCH.}

As a winter pasture and forage crop, Rye and Vetch is a combination hard to beat. In this case, the winter or hairy Vetch should be used, as this will not kill out even in the hardest winters. Planted in September, this crop will be ready to turn stock on by November. It will be the last green thing in the winter and the first in the spring.

The Vetch with the Rye makes a balanced ration as Vetch is one of the best legumes we have and very high in protein.

The advantages of mixing Vetch with the Rye are several. We get more and much better feed, and the fact that the Vetch is one of the best soil builders known means that we are increasing the soil fertility of the land.

During the past season something over one thousand acres of Vetch and Rye were sown in the Kaw Valley on potato land. This was simply as a cover, or green manure crop, being turned under about November first as a fertilizer. In this case Spring Vetch was sown, and with the best success. This coming year we are expecting this system to be followed in other potato growing districts such as the $\Lambda$ merican Bottoms near St. Louis, and the Scotts Bluff country in Nebraska.

Vetch and Rye is coming into its own, proving one of the best cover crops ever grown. Not only on potato land, but on any land which the farmer wishes to build up, this combination will be found one of the best.

\section{OUR EFFICIENT LAND- SCAPE DEPARTMENT See Page 46}

We wish especially to call the attention of Farmers and Country Home Owners to our efficient Land scape Department. We have over one hundred acres devoted to the growing of fruit trees, shade trees, ornamental shrubs, hardy plants, etc.

Our landscape architects are experts in this work. Estimates furnished free. Should you intrust us with the beautifying of your grounds you will be highly pleased with the results obtained. 


\section{SUDAN GRASS}

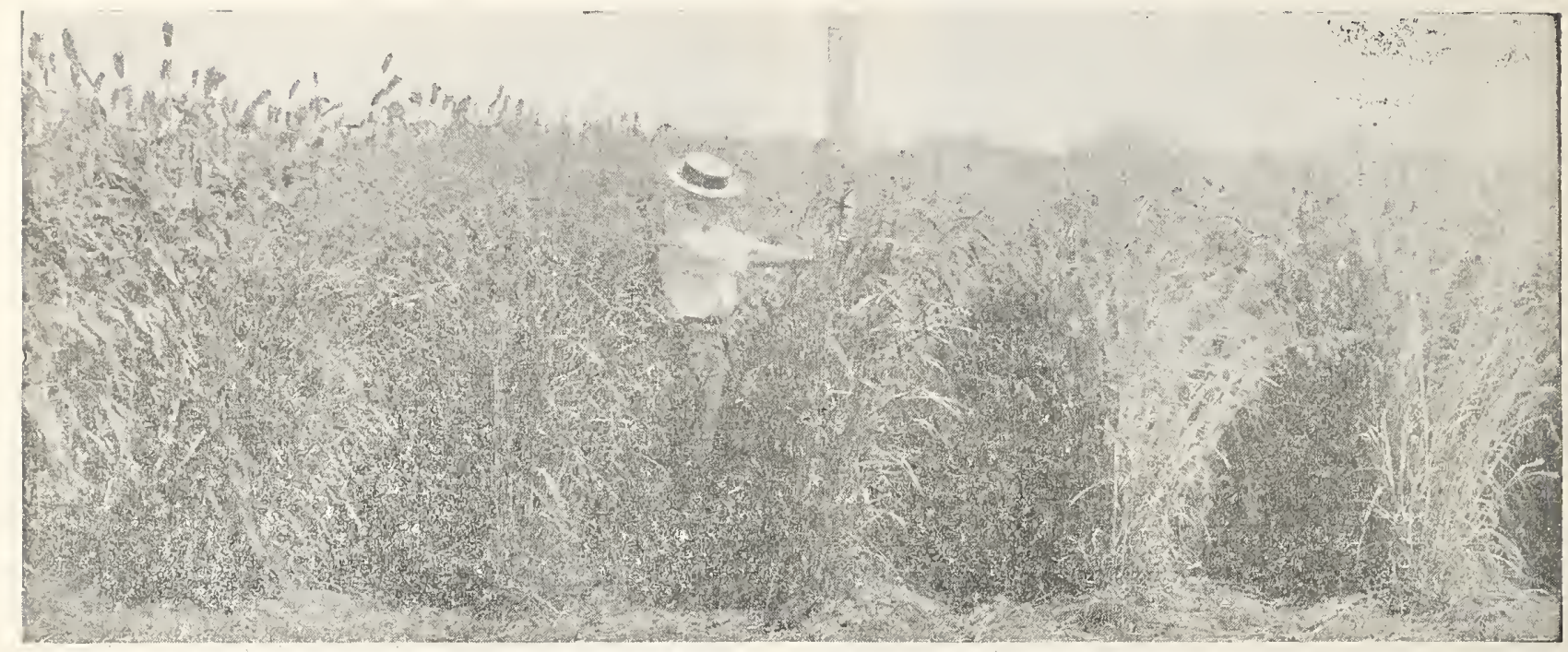

Sudan Grass is the wonder of the age. It is the greatest forage plant ever introduced by the United States Department of Agriculture. It see ns to have taken the country by storm.

A sweet, heavy-yielding grass; absolutely drouth-proof; grows successfully everywhere in the

West; stock of all kinds eat it greedily; yields more tonnage than any other forage crop per acre.

Every stockman and experiment farm that has tested this grass states that it is fine hay and stock eat it in preference to Alfalfa. It analyzes over 9 per cent protein.

We are now prepared to supply our customer 3 with the highest quality of seed, and want you to test out this wonderful crop this season. Write for quantity prices.

THE ORIGIN OF THE SEED.-In the year 1909 a small amount of this seed was brought into this country Irom Sudan, Egypt, by the United States Department of Agriculture. It has been thoroughly tested since its introduction in many sections of the United States-everywhere a success.

Sudan Grass is probably the wild original form of the cultivated Sorghums. It is a tall annual grass, growing, under favorable conditions, to a height of 6 to $10 \mathrm{f}$ set, but when broadcasted thickly it grows only 4 to 6 feet high. The stems are fine the largest stalks seldom larger than a lead pencil. Where the plants are scattered they stool abundantly, as many as 100 to 150 stalks coming from a single root. In general appearance, Sudan Grass is very much like Johnson Grass, but they are entirely distinct, for Sudan Grass lacks rost stalks and therefore never becomes troublescme as a weed. The stems are leafy, erect, and seldom lodging. The grass cures easily, making hay of excsllent quality, which is readily eaten by all kinds of livestock. It has been grown with marked success throughout the semi-arid regions, maturing szed even in South Dakota. It grows well through the humid regions, and from Central Missouri southward will ordinarily yield 2 and 3 cutting of hay in a saason. It is considerably earlier than the earliest Amber Sorghum, and will mature as far north as the Canadian line.

GROWING THE CROP.--It may be grown either drilled in cultivated rows, or broadcasted. If planted in cultivated rows the rows should be as close as possible, and yet permit of easy cultivation. In 24 to 3 )-inch $10 \mathrm{ws}$, 2 to 3 pounds of' seed per acre is ample; and, under conditions of very low rainfall, this method is reecmmendad. Under humid conditions. 18-inch rows are preferab'e. ana 5 pounds cf seed per acre are sufficient. For drilling or broadcasting, 15 pounds of seed per acre should be; usad. The seed should not $b \ni$ sown until the ground is warmthat is, about the time for planting corn. The young plants will withstand slight frosts without injury.

HARVESTING THE CROP.- The hay should be cut as soon as the grass is fully headed, and early cut ing is especially advisable where two or more cuttings per season are expected. The grass can be cut with a mower, but more conveniently with a binder, espocially in dry reg.ons, as the hay cures very readily in bundles.
SAVING THE SEED.-The grass yialds a heavy crop of seed especially in cultivated rows. If the seed is grown for commercial purposes, it is highly important that it be grown on land not infest 3 d with Johnson Grass as the seeds of the two are distinguishable only with difficulty. It is recommended that, in growing for seed only, it be cultivated in rows, taking great care to ho o out and eliminate any Johnson Grass or other weeds, etc., that may show in the Sudan Grass. It cro $₫ S$ 's very readily with all the cultivated varieties of Sorghum and when it grows near any such varioty more or less numerous hybrid plants will appear in the progeny. These hybrids do no harm in fields intend ed for hay, but whers a crop is to be harvested for seed the hybrid plants should be rogued out. This should be done preferably as soon as the hybrids appear in bloom, so as to prevent further crossing in the field; but in any event it should be done before the Sudan Grass is harvested. Sudan Grass seed weighs about 32 pounds to the bushel.

Sudan Grass, without doubt, has solved the hay question. It is the greatest drouth-resistant forage crop known. At the same time it does not blight where the moisture. is heavy, and under good saasonable conditions it yields a larger tonnage of hay per acre than any other crop known. It recovers rapidly after cutting, and the next crop is usually ready for harvest within 30 days from the first cutting. Sudan Grass has solved the hay question wherever grown. Farmers are looking for a crop with both a feeding value and a market value. This country has never produced enough good hay. Good hay always brings splendid returns. Hay is the bast forage and the most convenient to handle. Sudan Grass is a great producing crop, both in quality and yield, and makes a nutritious and palatable hay, which is greatly relished by cattle, horses and otlier farm stock. In feeding value, the hay is second to Alfalfa and far better than Miliet, which is usually grown as a "catch" crop. Its yiald is also much 


\section{OATS}

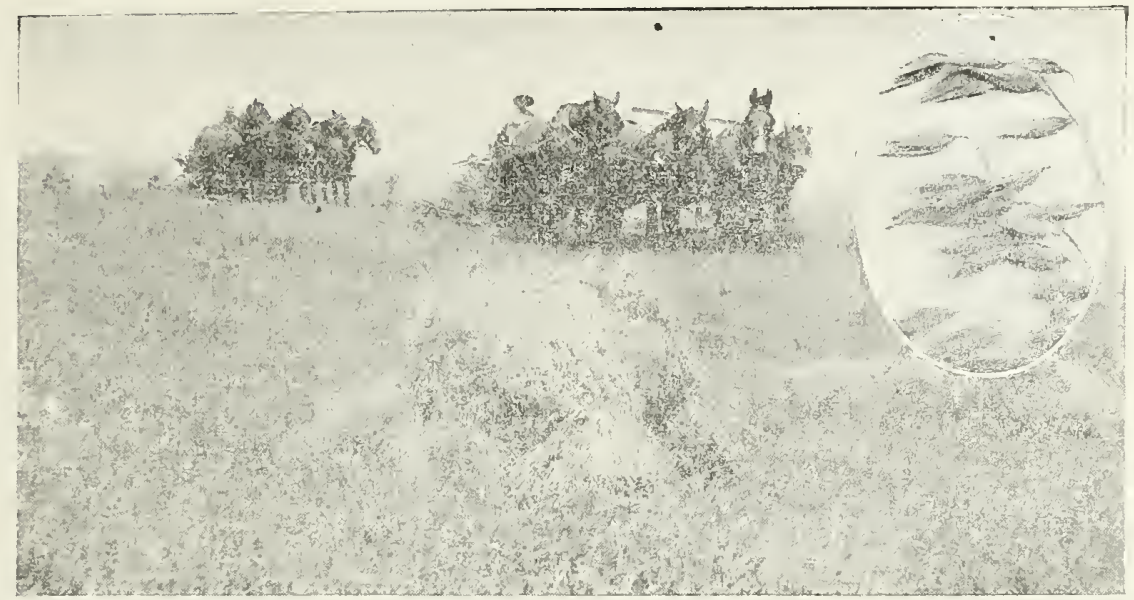

\section{TEXAS RED RUST-PROOF.}

DESCRIPTION.-The Texas Red Rust-Proof Oats are not a handsome Oats to look at, but what they lack in beauty they abundantly make up in certainty of crop and yield. They grow to a medium height, $3 \frac{1 / 2}{2}$ to 4 feet tall, having a sprangly head well filled with grains, often running 100 to 125 kernels to the head; also a splendid stooler. The grains or kernels are of' a yellowish-red cast, with a husk extending well out over the tip ends, hence do not weigh out quite as heavy per $m$ zasured bushel as some other varieties. but easily make up this difference in bushels. In brief, we can most heartily recommend these Oats and their adaptability to any place where Oats are grown, and esp ern friends and customers.

We have made a leador of our Rust-Proof Oats for several years and have found it the bast all-purpose variety, and it has given the very best of satisfaction. Many customers report extravagant yields and everyone speaks in the highest terms of it. We want to urge you to get started growing our Rust-Proof Oats.

This variety is a wonderful yie'der. Machine measures from a crop have shown a yield of' 128 bushels per acre. It is absolutely rust-proof. The grade of Oats is the highest plump, heavy berries, with lots of meat, which makes fine oat meal.
This rust-proof fature is a great deal in their favor for this climate, being subject to cool, damp weather, and the heavy fogs and dew of night and morning followed by hot sunshine during the day will often rust the oats. causing the straw to break and fall, and, instead of plump Oats, there is nothing but chaff or an inferior grade of Oats. When you sow Oats, it is worth a great deal to know you are insured from rust and blight. We have seen fields of Oats adioining fields of Rust-Proof that were rendered almost worthless frcm rust and blight and not paying the expense of harvesting and threshing, while the Rust-Proof made splendid yields of good, marketable Oats and plenty of bright straw.

Did your Oats pay last year? If not, try Texas Red Rust-Proof Oats. If you want your Oats crop to pay better than common varieties, try Rust-Proof Oats. Our stock of Rust-Prorf Oats this year is the finest and best we ever had. E ${ }^{\text {"ery }}$ bushel has b is free from weed seed and just the kind of seed you would wish to sow. If you need seed Oats, order this varlety, as it is sure to please.

Rust-Prcof has a stiff narrow straw leaf that stands up well against wind and rain and is still very valuable for feed. The berry is plump, old gold in color and well filled with kernels, gocd freding quality, medium early, maturing between the Champion and Common Oats. Price, $85 \mathrm{c}$ per bu.

\section{BARLEY}

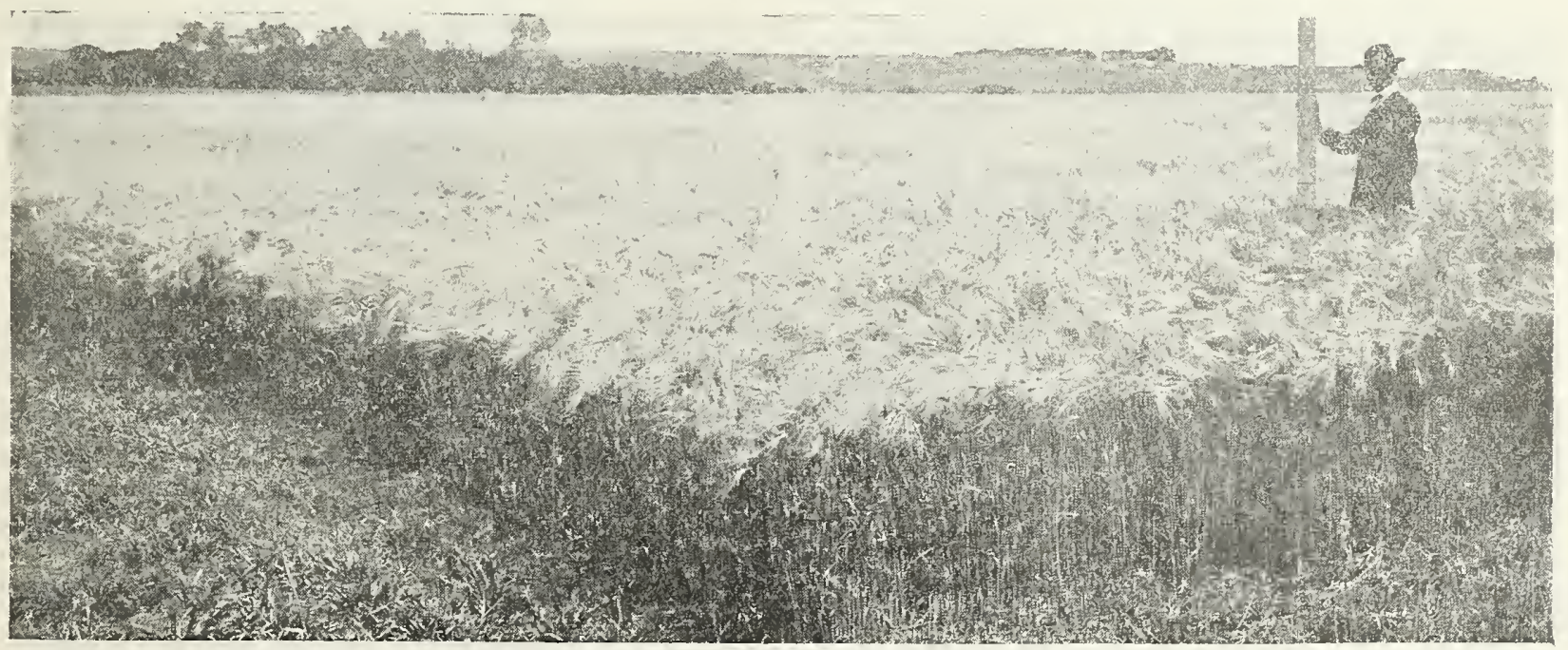

The demand for seed Barley increases each y ar. The farmers, even right here in the Corn Belt, have been thoroughly convinced as to its valuable feeding and yielding qualities.

Many who objected to Barley on account of the unpleasantness in handling the old-style bearded varieties 


\section{BARLEY Cont.}

are enthusiastic growers of the beardless sort. Many are sowing it in preference to Oats, for it will make more grain and feed per acre.

It is early; in this section being ready for harvesting the last of June or the first of July.

It stands up bettel than any other kind of grain.

The yield is almost invariably good, often yielding more per acre than Oats. feed.

Its muscle and bone-producing qualities make it a good

It is the best nurse crop for grass yet discovered.

Barley culture is similar to that of Spring Wheat or Oats. Full-plowed ground is preferable to early spring plowing. Do the work shallow and harrow the ground thoroughly after seeding. Sow early, putting in about $1 \frac{1}{2}$ to 2 bushels per acre.

IMPROVED WHITE HULL-LESS BARLEY.- Improved White Hull-less Barley is taking the lead as the most desirable variety of Barley to grow. This variety has become known and proven its worth as the most profitable variety that can be grown.

Our seed is of the finest quality, and we don't anticipate any trouble in filling your order or in delivering a quality of seed that will please you in every respect.

It is often grown for hay, coming very early and providing rich feed. It should be cut before it is ripe, while

\section{CANE AND SORGHUMS WRITE FOR PRICES}

The possibilities of Cane are almost beyond comprehension. Growing it for ensilage has become an established part of American agriculture and stock-raising. It is one of the very few types that meets the highest expectations.

To the utmost vigilance and mature deliberation of practical farmers in the selection of the most prolific types can be attributed the great popularity of Sorghum, as experience has demonstrated to a mathematical certainty that it is vastly superior to any other. It can be grown to perfection everywhere-in Texas and Manitoba, in Maine and California. There is nothing so good in the sweet Sorghum line as Cane for quick fodder. Sheep relish it, hogs grow fat on it, cattle glory in it, horses will jump wire fences to get into it, chickens - and, in fact, all things living on the farm-are fond of it.

For soiling or green feeding, Cane is of very high value, especially during the summer and autumn, when the pastures are dry and it is hard to find sufficient fod. der to keep the animals in a thrifty condition. It is one of the best foods that can be used to feed growing animals and alsc the dairy cattle, on account of the flow of excellent milk which it will produce. An acre of Cane often produces as much as 40 tons of green fodder, but the avelage yield is probably only 20 tons.

Cane makes a grand summer pasture for all kinds of stock, especially for sheep and hogs, when used before it heads out. The hay is very nutritious and is relished by all kinds of stock, including hogs. The yield of cured straw is green; in this condition it is relished by all kinds of stock. The straw is stiff and straight and seldom if ever does it lodge. Prices on application.

SIX-ROW MANSHURY BARLEY.-This Barley has made millions of dollars for farmers. Hundreds of farm. er's tlink there is no Barley in the world that equals Manshury. It is an early six-rowed Barley that grows very vigorous and strong, bearing long heavy heads filled with nice plump kernels that discolor very little with wet weather.

Manshury is an ideal grain feed for horses, and when ground is fine for hogs and other stock. It is a profitable crop to grow for the market, malters paying the highest price for Manshury. It will do well on any kind of land or in any locality where other crops grow. It prefers a soil lighter than is necessary for good Wheat. Prices on application.

CHAMPION BEARDLESS BARLEY.-This Barley is as easily grown and handled as either Oats or Wheat. It is an improved beardless variety of a distinct six-rowed type. It is similar to Success Barley, but is larger, has a longer straw, and yields more per acre. Being beardless, it is pleasant to handle, and the straw can be fed to stock without fear of injury. Ask for prices.

hay is about 12 to 15 tons per acre. Cut when heading out, leave for two or three days on the ground and then put up in shocks. The silage made of Cane is exceptionally nutritious. It is best cut for silage when the seeds begin to harden, as if cut in too immature condition it is liable to become sour. Cow Peas and Soy Beans are quite often mixed with Cane for the silo. This will greatly increase the feeding value. As a "catch" crop, Cane is frequently used. It can be sown in mid-summer after an early grain crop, or can be planted in place of other crops if they have been destroyed by hail, flood or insects.

TEXAS SEED RIBBON CANE.-For syrup, forage and ensilage. One of the best varieties that you can plant for syrup purposes. Every planter who has tried this wonderful rariety is more than well pleased; and for the increasing demand of ensilage crops you cannot find a Sorghum that will give you more universal satisfaction. The superiority of this Cane over other Sorghums is so great that when once grown it always will be planted, wliether for forage, ensilage or syrup. The stalks grow from 12 to 15 feet high, being ready to cut and grind the latter part of August, while common Cane is not usually ready to cut before October. Cut with the foliage and run through the rrill, it makes the finest kind of ensilage for all kinds of stock. The yield of molasses is from 250 to 400 gallons per acre. It will grow anywhere that Sorghum will grow. In planting, prepare the ground and cultivate the same as for Sorghum. Plant' in rows $3 \frac{1}{2}$ feet apart; 6 to 8 pounds will plant an acre if planted in drills. The Seeded Ribbon Cane is sweeter than the Orange, the syrup lighter colored.

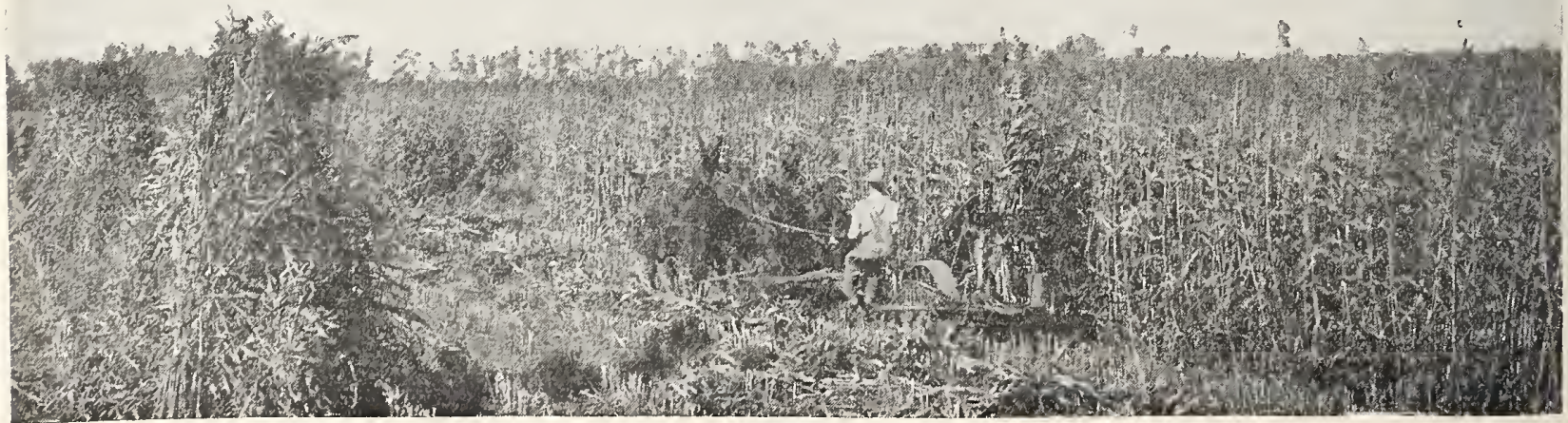




\section{CANE and SORGUMS Cont.}

EARLY AMBER.-This is the quickest maturing variety of the sweet Sorghums, and was formerly the variety most generally grown for syrup and for forage. It is still preferred in the Northern States because of its earliness, but in the Southwest Red Top has proven to be a heavier producer.

ORANGE.-This is also an old and popular variety for both syrup and forage. Usually matures ten to fourteen days later than Amber.

RED TOP, OR SUMAC.-Of the many varieties of sweet Sorghums, Red Top or Sumac is the one most gen. erally grown. It is vigorous and drouth resistant, and makes larger yields than any other sweet Sorghum. The seeds are red to orange yellow.

HONEY SYRUP CANE.-The favorite syrup producer. As a syrup producer it has no equal, being exceedingly juicy and sweet, making from 300 to 600 gallons per acre, highly prolific, sometimes producing five to seven stalks from one seed. Matures about the middle of August to October, owing to time of planting. Will keep green and stand, if desired, until killed by frost, allowing the farmer to take his own time to harvest for syrup.

Ask for quantity prices.

\section{FETERITA}

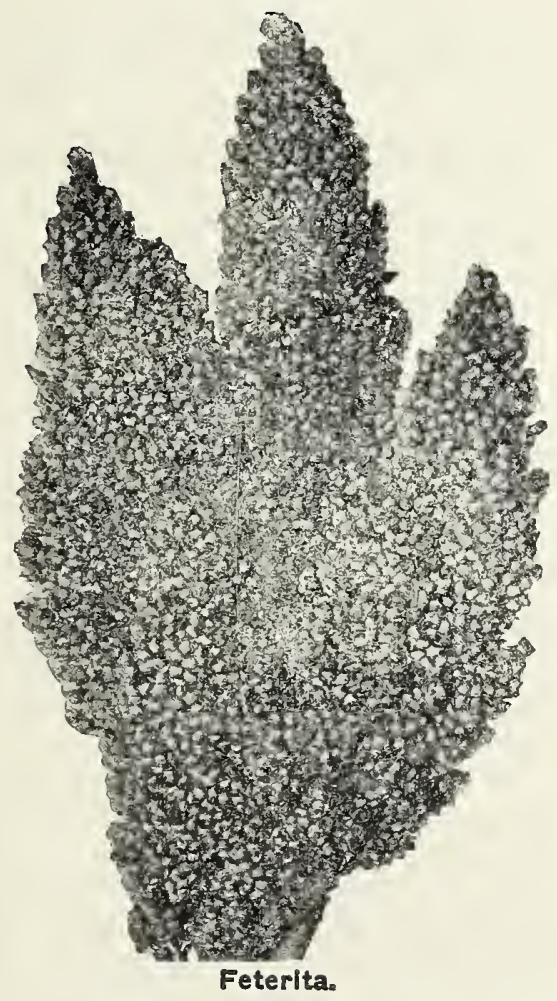

Feterita belongs to the same class as Kaffir Corn and Milo Maize, but is considerably earlier than either one, and is said to stand drouth better and makes a larger, softer grain. In manner of growth, it is about half way between Kaffir Corn and Milo Maize, but the heads stand perfectly straight and erect, and the grains are very large, pure white, and comparatively soft. It can be fed without grinding.

The results obtained in the various agricultural schools and experiment stations and by others who have given it a thorough trial, all tend to prove that it is not only of particular value, but has many points of superiority over both of the more familiar grain Sorghums, Milo Maize and Kaffir Corn. Feterita has withstood the drouth and in practically every instance has matured where Kaffir Corn and Milo Maize are failures.

Ask for prices.

\section{MILO MAIZE}

A non-saccharine Sorghum of high value; cultivated like Corn. It is a vigorous grower, of deep green color, attaining a height of 8 or 10 feet. Some stalks develop 20 heads. The seed is fed to horses, cattle, chickens, etc. It will mature its main head in 100 days, and will continue growing until frost. Plant 4 to 5 pounds per acre. Similar to Kaffir Corn, but grows larger heads and produces a slightly larger grain. Cultivation is same as for Kaffir Corn. It will pay you to try it.

Ask for prices.

\section{SUNFLOWER}

The Sunflower during the past two or three years has proven to be an excellent crop for ensilage. Poduces an enormous tonnage of from 20 to 30 tons per acre. Fed to dairy cattle, it is found to be satisfactory in every way. The cows were just as anxious for it and produced as much milk as when fed on other ensilage. The seed is also valuable as a poultry and hog feed. Should be sown in rows far enough apart to admit of cultivation. Two to 3 pounds are sown per acre.

\section{RAPE}

DWARF ESSEX RAPE is an annual, bearing a close resemblance in leaf' and stalk to the Rutabaga, but both leaves and stalk are more numerous in the Rape plant and of a taller habit of growth. It is a pasture plant, which may be eaten off by any kind of livestock, but it is preeminently fitted to furnish pasture for sheep, cattle and swine. A good crop will furnish at least 12 tons of green food to an acre. Rape thrives best on a good soil, rich in vegetable matter. Slough lands are excellent.

When Rape is sown broadcast, 5 pounds of seed an acre will suffice; when sown in rows, say 30 inches apart and cultivated, from 1 to 2 pounds an acre will be enough. Lb., 15c; 100 lbs., $\$ 12.00$.

\section{BUCKWHEAT}

Buckwheat should be sown about the middle of June at the rate of from $1 / 2$ to $3 / 4$-bushel per acre You will avoid the danger of its spoiling by threshing as soon as dry.

JAPANESE.-This is a very popular variety of Buckwheat. The plant is of stronger growth than common Buckwheat and resists drouth and blight much better. The grains are a rich dark brown, having a thin hull and larger grain thall Silver Hull. It ripens a week earlier than other varieties and is perhaps the best for light or sandy soils and for the dry climate of the West.

SILVER HULL.-This is a thin-shelled Buckwheat of a silver gray color. It has a very solid, medium-sized grain. It stays in bloom longer than the other varieties, thus producing a larger crop. The flour made from Silver Hull is light in color. This variety is most excellent for bees and is very popular. 100 lbs., $\$ 5.00$.

\section{CANADIAN FIELD PEAS}

After grain has been grown year after year on a field a great deal of the life and fertility is taken from the soil, and there is no crop which will do more to enrich the soil than Canadian Field Peas. Peas are second only to Clover in their soil-enriching properties, and can be grown under almost any conditions of soil or climate. There is always a market for Peas, or they can be properly ground and fed to stock. Vines make rich, nutritious hay, which is especially good feed for cows. When sown alone, about 2 bushels per acre are required, and they can be matured and threshed when dry. Yield wili vary from 30 to 60 bushels per acre. For hay, Peas and Oats should be sown together, using I bushel of Peas and 1 bushel of Oats per acre. Peas should be sown first and covered to a depth of about 4 inches, then drill in the Oats. Vines grow to height of about $3 \frac{1}{2}$ feet.

Oats. Vines grow to height of about $3 \frac{1}{2}$ feet. Lb., 20c; 100 lbs., $\$ 10.00$ 


\section{KAFFIR CORN}

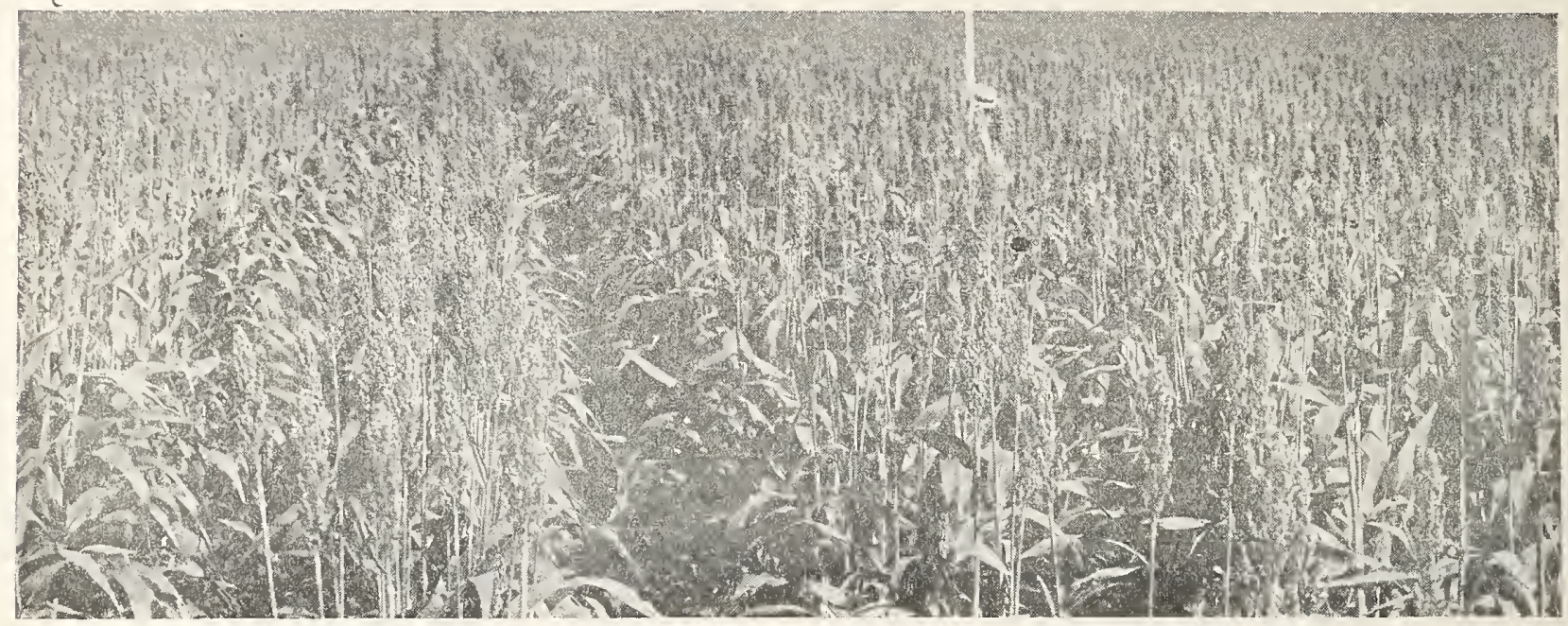

Ask for quantity prices.

Kaffir Corn is the principal grain crop in rnaly sections of the Southwest oll account of not being affected by drouth. It is being more generally used, and we take pleasure in recommending it, not only as a grain, but as a hay crop. Kaffir Corn makes a great yield of the finest kind of feed, when sown broadcast and cut for hay. It has advantages over Cane, as the hay can be cured the same as Millet and stacked, making higher quality of feed. We have a large stock of extra fine seed, testing high for germination, and can supply you with seed that will mare the best yield. Valuable both for fodder and grain. Always yields an immense crop of seed, even on the poorest of soils and in driest seasons. Especially adapted where summers are hot and dry.

Kaffir Corn has proven invaluable to Western farmers as a fodder and grain crop during dry seasons. It does very well everywhere in the Corn belt and can be grown successfully as far north as Minnesota. On good jround it will yield 50 bushels of grain per acre, besides affording a great amount of fodder. Every farmer should plant at least a few pounds of Kiffir Corn for his poultry. 'The grain cannot be excelled for fowls.

If cut when first seed heads come into bloom, a second growth will shoot up and produce ancther crop of forage or fodder, which sells for more on the market than Clover hay.

Sow broadcast and handle like Cane, putting on from 75 to 100 pounds per acre, or drill with Corn planter, putting on about 10 pounds per acre, then cutting with a corn harvester and threshing like grain. Some faed it to stock, heads and all, while others cut the heads off and thresh them. Any way it is treated it makes a valuable feed.

While for forage and grain the Kaffir Corns lead among the grain Sorghums, a longer season is required for them to mature. The Kaffir Corns are largely used for roughage, because the stalk is slightly saccharine.

STANDARD KAFFIR CORN.--Sow in rows $21 / 2$ to $: 1 / 2$ feet apart and cultivate the same as Corn. Five to 10 pounds will seed an acre in rows, or $1 / 2$ bushel broadcast. $\$ 2.50$ per 100 lbs.

\section{DWARF KAFFIR CORN}

An especially fine fodder plant. It grows from $3 \frac{1}{2}$ to 5 feet in height-depending on the quality and condition of the soil and also on the weather conditions. The heads are larger and more shapely than those of Kaffir Corn. Stalks keep green, not getting hard like other Sorghums, and are juicy and brittle. Dwarf Kaffir Corn makes fine fodder, either green or dried, and is relished by horses and cattle. Dwarf Kaffir Corn is the result of careful selection and produces a plant of uniform dwarf growth. It makes a crop in less time than the usual type of Kaffir rorn.

\section{DWARF BLACK HULL KAFFIR CORN}

Carefully selected seed, which produces a uniform dwarf' growth, usually from $31 / 2$ to 5 feet in height. Finely shaped heads, with heavy seed formation. Makes excellent fodder, either dried or green. Does fine on upland.

\section{BROOM CORN}

It will certainly pay you to investigate this crop and see if you cannot raise it with profit. You can also make your own brooms. You cannot get much of a broom for less than $\$ 1.00$, and for a few cents you can get sufficient seed to make brooms to last you for years, so why not buy some seed?

Brocm Corn is one of the most profitable crops the farmer can grow. We would strongly advise more of our farmers to grow this crop.

Broom Corn requires soil and culture similar to Corn, but should be planted later. It pays better to have the ground in prime condition. It is frequently jlanted in drills $3 \frac{1}{2}$ feet apart, leaving the plants 6 inches apart.

EVERGREEN OR STANDARD.-Is a favorite in Kansas, Nebraska and Missouri. It grows to be a good length, and if cut at the proper time has a good color, but if allowed to stand will redden at tip as seed ripens. Ask for prices.

DWAFF EVERGREEN.-This is a very popular variety on account of its not being so liable to blow down and lodge as the taller varieties. Heads are very bushy, and t makes a fine yield. Ask for prices.

OKLAHOMA DWARF BROOM CORN.-This is the variety most generally grown in the Southwest. Very early, strong-growing, and productive, but only about 5 feet high, making it easy to handle the long and wellfibered brush. Seed is from progressive Broom Corn growers who know the market requirements and improve their seed by selecting each year. Ask for prices. 


\section{LAWN GRASS SEED}

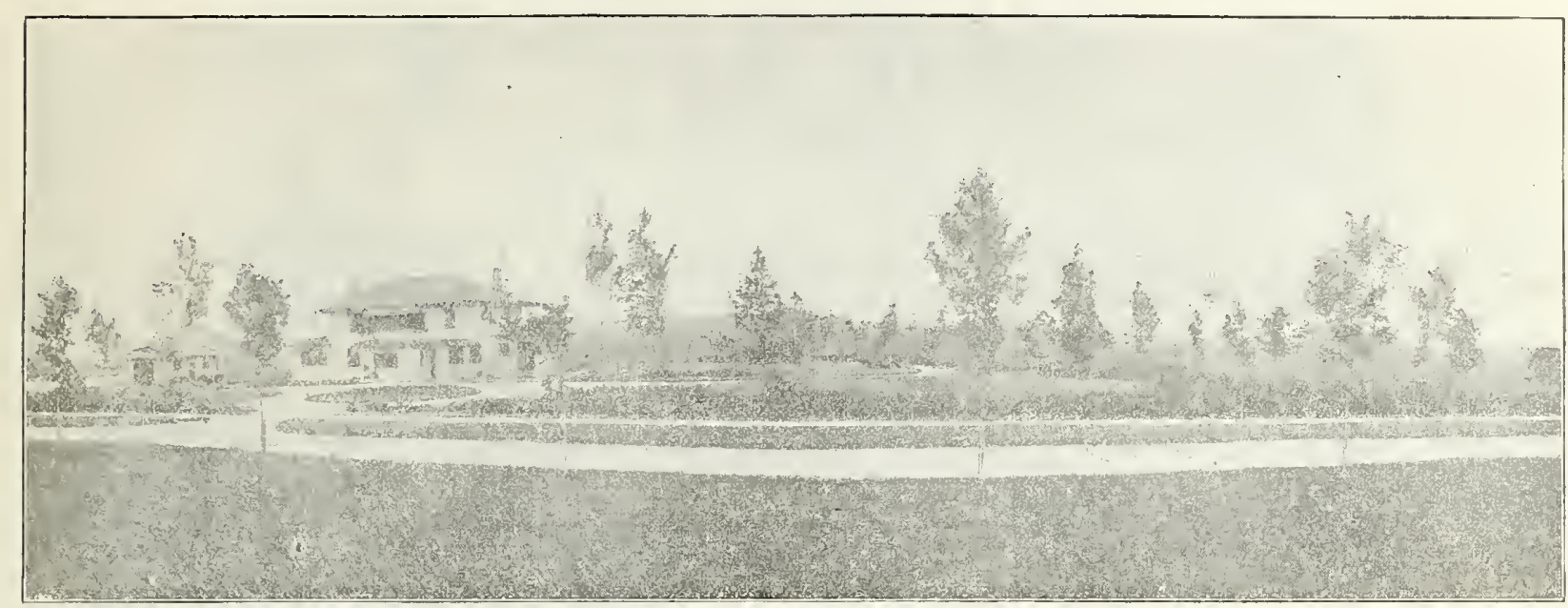

The essentials for a fine lawn are: First, a rich well-drained soil; second careful preparation of the ground, making it as fiue and smooth and mellow as pos sible; third, a wise selection of seeds; fourth, sowing at such a time as to give the young plants a chance to become well established before being subjected to very dry or cold weather or to the direct rays of the hot summei sun. However much care is bestowed on the soil and seed, no lawn will be beautiful without freruent mowin and rolling. Too much care cannot be bestowed upon the selection of Grasses, as some varieties are the most luxuriant in spring, others in summer, others again in autumn, and a combinaticn of the proper sorts is required for a perfect, carpet-like lawn. It may be planted early in spring or fall, and should be sown at the rate of 60 to 100 pounds per acre. If sown in the spring, sow as early as possible, making the surface very fine and smooth, then raking it over and sowing the seed just before a rain. which, if the surface has just been raked, will cover the seed sufficiently. For fall seeding, sown before the autumn rains and early enough to enable the young grass to become well established before very cold weather, when a light dressing of manure should be given.

AYRES EXTRA FINE MIXED.-We have given much thought and make many experiments to secure the best selection, and think our Ayres Mixture is the best possible for shaded lawns. one pound is the mininum quan. titl, sufficient to sow 600 square feet. One lb. $50 \mathrm{c}, 10 \mathrm{lbs}$. $\$ 4.50,100$ lbs. $\$ 40.00$.

AYREES GOLF COURSE MIXTURE.-While there are on the market numerous ready-prepared Golf Mixtures of more or less value, we have found that the best results are obtained by giving individual attention to each customer and making a special Mixture to suit his needs. Write us a description of your links, telling what the nature of the soil is, how drained, how much it has the sun, whether the wintels are long or open, and whetler the sumniers are wet or dry, and we will offer you two or more Mixtures especially adapted to the various parts of Four grounds. Write for prices.

KENTUCKY BLUE GRASS.-It has been thoroughly demonstrated that the soil of Kansas is as well adapted for raising Blue Grass as that of Kentucky. We have the facilities for harvesting and caring for the seed, and a market for distributing it lies at our door. The seed raised here is fully equal to that raised in any other part of the country, the germinating qualities of it being above the average of the seed usually shipped in. Possessing all these natural advantages.

In connection with White Clover, Blue Grass forms the finest and closest lawn; for this purpose an extra quantity of seed should be used-say 3 bushels of Blue Grass and 2 pounds of White Clover per acre or 1 pound for 150 feet: if sown by itself f'or pasture, 14 pounds is sufficient. Sow early in the spring or during the months of September and October. One Ib. $60 \mathrm{c}, 10 \mathrm{lbs}$. $\$ 5,50$.

ENGLISH BLUE GRASS OR MEADOW FESCUE,-AIl points considered, this Grass must be regarded as one of the most valuable Grasses that can be sown anywliere in this country. Its most important features are that it is drouth-resisting, frost-resisting and furnishes an abundance of pasturage early in the spring and late in the fall when other Grasses have not come up or have died out. It is suited to a wide range of soils-does well on loainy, clay, and gravelly soils, and thrives on heavy black loan, and strong and low-lying soils. In wet places in a pasture when trampled down by the stock where Timothy, Red Clover, and Kentucky Blue Grass fail, Meadow Fescue is the only Grass that will keep these places productive, and no amount of trampling is able to destroy it. It is not adapted to light, sandy soils.

Meadow Fescue is of the greatest value if sown in connection with other Grasses; and as farmers realize the value of mixtures of perennial Grasses for pasture or meadows, the demand for Meadow Fescue will be greatly increased, mainly because it is so sure to grow and come up quickly. keeping the weeds down and furnishing for age while the weaker Grasses are getting started. Mealow Fescue matures at the same time as Timothy and Red Top and Alsike Clover, and for meadows these varieties are often grown together. It is easily exterminated. When plowed up, it is dead for keeps. Sow 10 to 15 rounds per acre broadcast without a nurse crop. One Ib., 50c; $10 \mathrm{lbs}$. $\$ 4.50$.

BERMUDA GRASS.--Peculiarly adapted to the Southern States. A delicate Grass, valuable alike for lawn and hay crop. Grows on any soil. Oklahoma Experinient Station resommends it highly. It does well in the south part of Kansas and Southern States generally. A dry weather Grass, and is splendid to bind locse soils togetler. Propagate by divisicn of the roots or sow the seed in amounts of 5 to 6 pounds to the acre. Sow from April to June. One Ib. $45 \mathrm{c}, 10 \mathrm{lbs}$. $\$ 4.00$.

WHITE CLOVER.-This is a low, close-growing Clover, with round white heads, and very fragrant; excellent for pasture, and when mixed with Kenturky Blue Grass makes the finest kind of a lawn and is universally used for this purpose in the United States. It also makes excellent pasture, and is very nutritious for sheep and cattle. It does well on almost any soil. Sow 5 to 8 pounds per acre alone for pasture; for lawn, 1 pound to 400 square leet. One lb. $65 \mathrm{c}, 10 \mathrm{lbs}, \$ 6.00$.

Write for prices on larger quantities and special mixWures. 


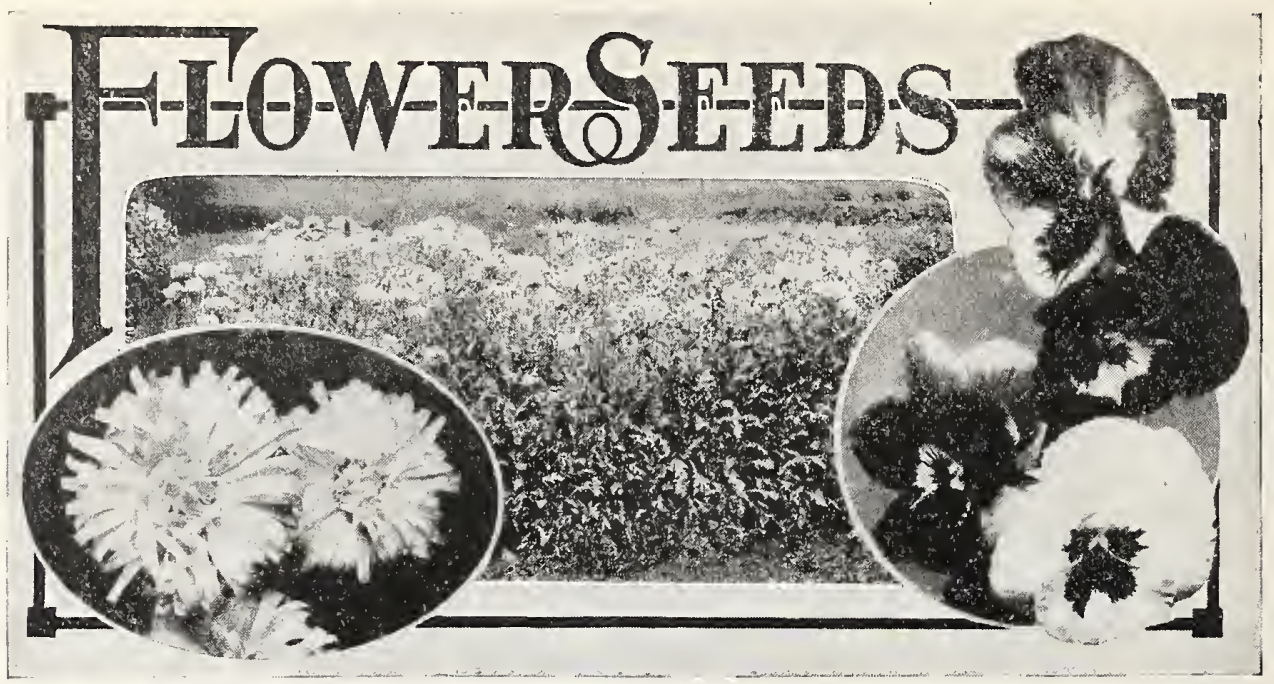

We believe we are the foremost growers of SELECT flower seeds in the United States. Our Sunny Slope farm in Independence, Mo., and our Blue Ridge farm on Blue Ridge boulevard at 39th street in suburban Kansas City, are model flower farms. All operations are under the direct supervision of Bryson Ayres and the greatest care is taken to have all szeds absolutely true to name.

ASTERS.

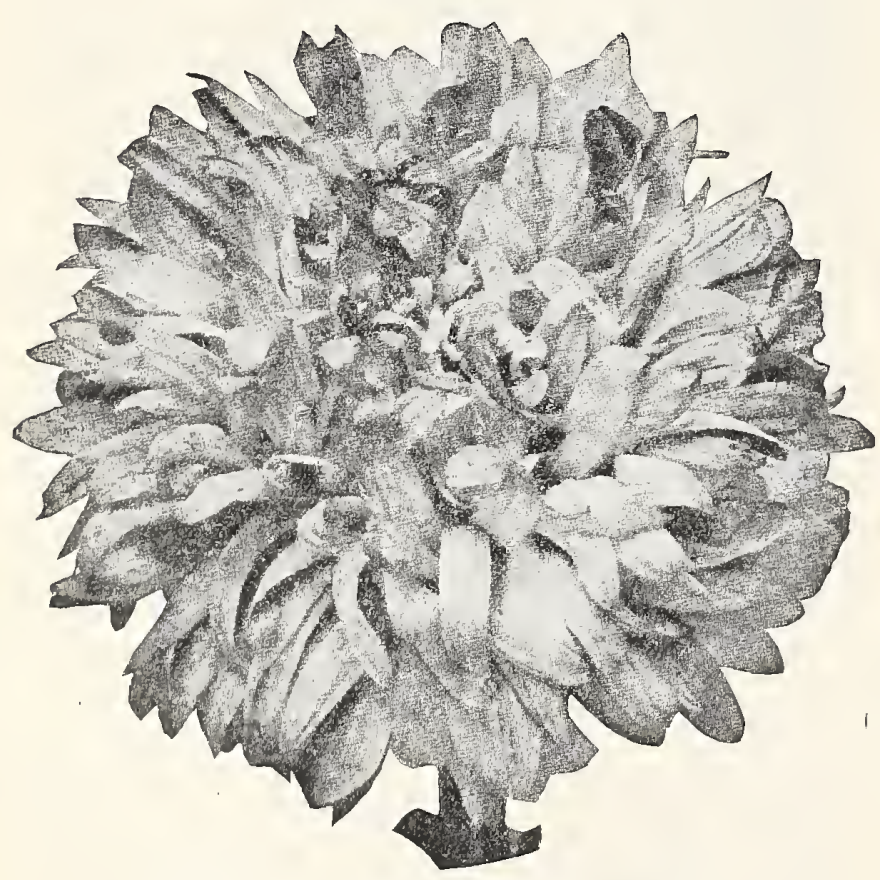

ASTERS, AYRES IMPROVED AMERICAN.

The varieties below are all of American origin, and are the "cream" of the many distinct sorts originated in Amer ica. The lover of asters should have every one of these in his collection. They represent the highest
asters. Carefully grown from selected seed.

CRIMSON GIANT. The plant is vigorous, of upright, branching growth, with strong stems 18 inches long, carrying fine double bright crimson flowers 4 inches in diameter. Grows 24 inches high. Packet, 15e: 1/1 oz., 50e. ROCHESTER OR MIRADO. This superb variety is a branching type of the Giant comet. The double flowers charming shade of silvery lavender-pink. Packet, 1se; $1 / 4$ oz., 50e: oz., \$1.5.5.

WHINE MIKADO. The large, pure white flowers measure from 4 to 5 inches across the long petals being artistically curled and twisted. The plants are of branching habit, 18 to 24 inches high. Packet, 15e; 1/4 oz.. 50e.

PEERLESS PINK. A most satisfactory variety for either bedding or cutting. The plants grow 24 to 30 inches high, of strong branching growth. The fine double flowers are color is a wonderful and most pleasing shade of rich pink. color is a wonderful and
Packet, 15e; 1/4 oz., 70e.

SIINSATION. The flowers are of a brilliant cardinal sharle. The plant is of branching habit, attaining a height of 1.8 to 24 inches, and the flowers are borne on stems of 1.8 to 24 inches, and the flowers are borne on stems cates, a "sensation." Packet, 15c; 1/4 ox., 8ive.

LAVINDIR GIM. One of the finest feathey flowers in the beautiful comet type. The coloring is silvery white when first opening, changing to the most delicate shade
of lavender when fully expanded. An excellent early bedding variety. Packet. 15e; 1/1 oz., s.je.

GIANT CREgo. Mixed packet, 10c.

DWART VICTORIA. Mixed packet, loc.

JAPANESE POMPON. First introduced by us in 1914, but owing to the war, we were compelled to wait until now to distribute seed. Truly a floral treasure. Finest mixed. Packet, 25e.

A CROCLINIUV. Beautiful strawberry. Shades of pink and red. Wonderful dried for winter bouquets. Price, nacket, 15e: large packet, 35c.

AQUILEGIS. Danish mixed. Similar to Rocky Mountain Hybrids, but much larger and more prolific. Price, per packet, 15e; larme pacliet, 35e.

ALYssum (Sweet Alyssum). Little gem. Most popular bedding variety. Packet, 10e.

AMARAn'Thus. Tricolor Splendens. Per packet, 10c.

INTIRRIINUM (Snapdragons). We grow all the leading colors, such as brilliant rose, shell pink, scarlet red, maroon, yellow, white. Separate colors or mixed. Per packet, 10e: large packet, 25e.

AzCTo'is GRANDIS (Blue-eyed African Daisy). A very popular daisy which blooms first season from seed.

BásAM. Finest mixed. Packet, 10c; large packet, 25c.

HALloon VINE. Annual, climbs. Packet, 10c: large palket ase.

BRACHYCOME. (Swan River Daisy). A profusion of blue daisy-like flowers, all summer. Packet, 10\%: large packet, 250.

CALENDULA. Lemon, orange, scarlet, White. Separate colors or mixed. Packets, 10e.

CALIIOPsis. Annual varieties. Mixed. Packet, 10e.

CAminula (Canterbury Bell). Persicifolia Grandiflora. Fine mixed. Packet, 10c; large packet, 25e.

CA NIYTUET, GIAT HYACINTH. Flowered. White. Large packet, ¿25e.

CANDYTUET. Large flowered. Mixed. Packet, 10c.

CARNATION. Annual flowering. Mixed. These bloom the first season, and are even more fragrant than our hot- 


\section{FLOWER SEEDS-Cont.}

\section{CELOSIA. (SEE NEXT PAGE)}

CELOSIA ARGENTEA. Beautifully plumed. Our mixture contains all the colors of the rainbow. Packet, 10e; large packet, $25 c$.

CELOSIA COMPACTA CIIRYSANTHEFLORA. The greatest floral discovery of the century. Large, compact, chrysanthemum-like flowers in many colors and shades. Annual. Seeds sown outdoors by May 1 st. Will bloom from August until frost. Packet \$a.so. CELOSIAMUM. Our own creation. Beautiful ball shape
resembling a huge chrysanthemum. Color. cordinal red. Introduced by us 1919 . foe per nacket: $\mathbf{Z}$ for $\mathbf{s}^{3} .00$.

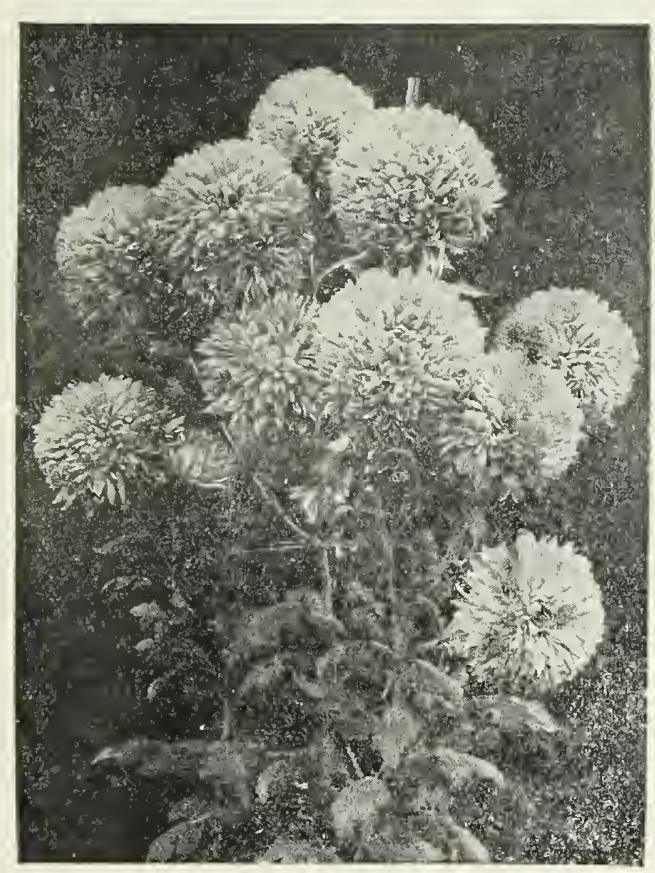

CELOSIAMUM.

CHRISA NTHEMUM. Annual summer variety. New, very fine golden yellow; blooms from early summer until frost. Packet. 10e; large packet, 25 .

CENTA UREA CYANUS (Cornflower). Double bachelor button. In this we have the finest mixtures' in existence. It cannot be compared with the old single form flowered types. Packet, 10e; large packet, $25 e$.

CENTA UREA IMPERIAL. Sweet scented. Pink. purple, lavender, white, or mixed. Packet, ioc; large parket, z5e.

ChINGS LANTERN PhANT (Physalis Franchetii). Packet, 10c: large Packet, 25e.

CLARKIA (Elegans), Beautiful salmon pink or mixpe. Packet, 10e; large packet, 25e.

Comofa scandens. Packet, $10 e$.

Columbing. See Aquilegia.

COREOPSIS, LANCEOLATA GRANDIFLORA. Golden yellow. Packet, 10c; large packet, 25e.

\section{COSMOS.}

GIANT FlowereD. Pink, crimson, white or mixed. Packet, 10e; large packet, 25e.

Double and single crested: Sunny slope mixture. $\pi$ e think this grand double and single crested cusmos the greatest and most valuable acquisition to the flower kingdom. The immense double flowers remind one of chrysanthemums, yet they have the delicate texture of the rarest orchid. We are fortunate in having grown a large amount of this seed. Packet, 15e; large packet, 35c.
LADY LENOX. Pink and white. I'acket, 10e; large packet, 25e.

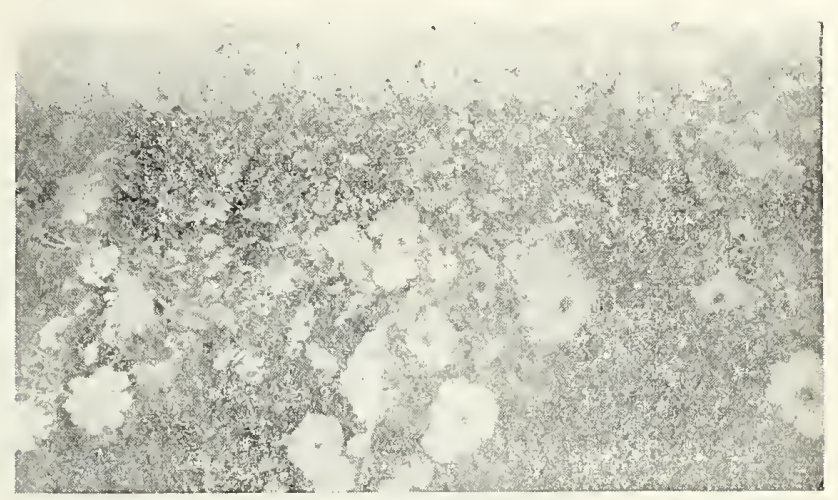

Cosmos

CYPIESS VINE.. Cardinal climer. Annual climher, delicale fern-like foliage and brilliant cardinal flowers. Packet, 15e: large palset. 5e.

CTCUMER VINE. Splendid for trees and fence. Packet, 100: liver parket ase.

\section{DELPHINIUM.}

JAPA NESE. I'acket 10e; large packet, 25c.

FormosUM. Dark blue with white eye; very popular. Picket, 10c; large waker, 25c.

BEllidonr A. Turquoise blue. Packet 10e; large packet, sec.

DAISy (Shasta), Packet, 10e; large packet 25c.

DAISY (Double Bellis). English strain. Pachot, roc; large Tacket, 25e.

DIATHUs. Annual varieties, Good mixture. Parket, Ioc. DIANTHUS (Barbatus). See Sweet William.

ESTHSCIIOLT\%IA (California Poppy). Golden, orange vellow rose. wlite, crimson. cardinal, or finest mixed Packet, 10e; linge packet, 250.

LSCHSCHOLTziA (Bush). See Hunnemanja.

FuPhorida (Marginata). Everlasting flowers, or straw flowers for winter bouquets. Mixer. Packet, 10c; large Packet, 25e.

TUPHOREIA METRROI'HYLLA. Summer Poinsetta. Orange, scarlet, leaves resembling a Poinsetta blossoin. Large Packet, 35e.

FEVEREFW. Packet, 100 .

FOrGET-ME-No' (Myosotis), Beautiful blue. Facket, 10e; larye pactict, ase.

FOUR-o'Clocie. Paeliet, 10e.

GALLARDIA. Packet ioe; large packet, 25e.

GERANIU⿴. Paeket. ä̌e.

GoDETIA. Good mixed. Panket, $10 \mathrm{c}$

GOMPHIREA (Globe Bachelor's Button). Packet, 10e: large packet, $25 e$.

Gormos (Ornamental) Ayres' American and Iuropean mixed. Very fine. Packet, 10c; lirge packet, s5e.

Grisses (Ornamental). Annual varieties; mixed. Con tains the cream of the annual grasses throughout the world. Fine dri

GYPsopHILA (Baby's Breath). Fine with bouquets, especially Sweet Peas, I'ncket, 10c: large packet, zōe.

GYPSOPHILA PANICULATA (Perennial), Large packet, 25 .

HELIANTHUS. See Sun Flower.

HELICHRYSUM (Original Strawflower). Everyone should grow some of these beautiful flowers to dry for winter bouquets. Our mixture is the finest in existence. Pastel shades are included in this mixture, as well as the most vivid shades of red, rose, and yellow. Packet, 15e: large backet, 35e.

Heliotrope. Giant Hybrids. Mixed. Paeket, 10e; large packet, 25e.

HOLLYHOCK. Double. Light pink, maroon, rose scarlet, yellow, white, crimson. Fine mixture. Packet, Ioc; large packet asc. 


\section{CELOSIA CHRYSANTHEFLORA \\ TEN ACRES OF AN "EVERLASTING" BLOOM NEW TO THE FLOWER WORLD.}

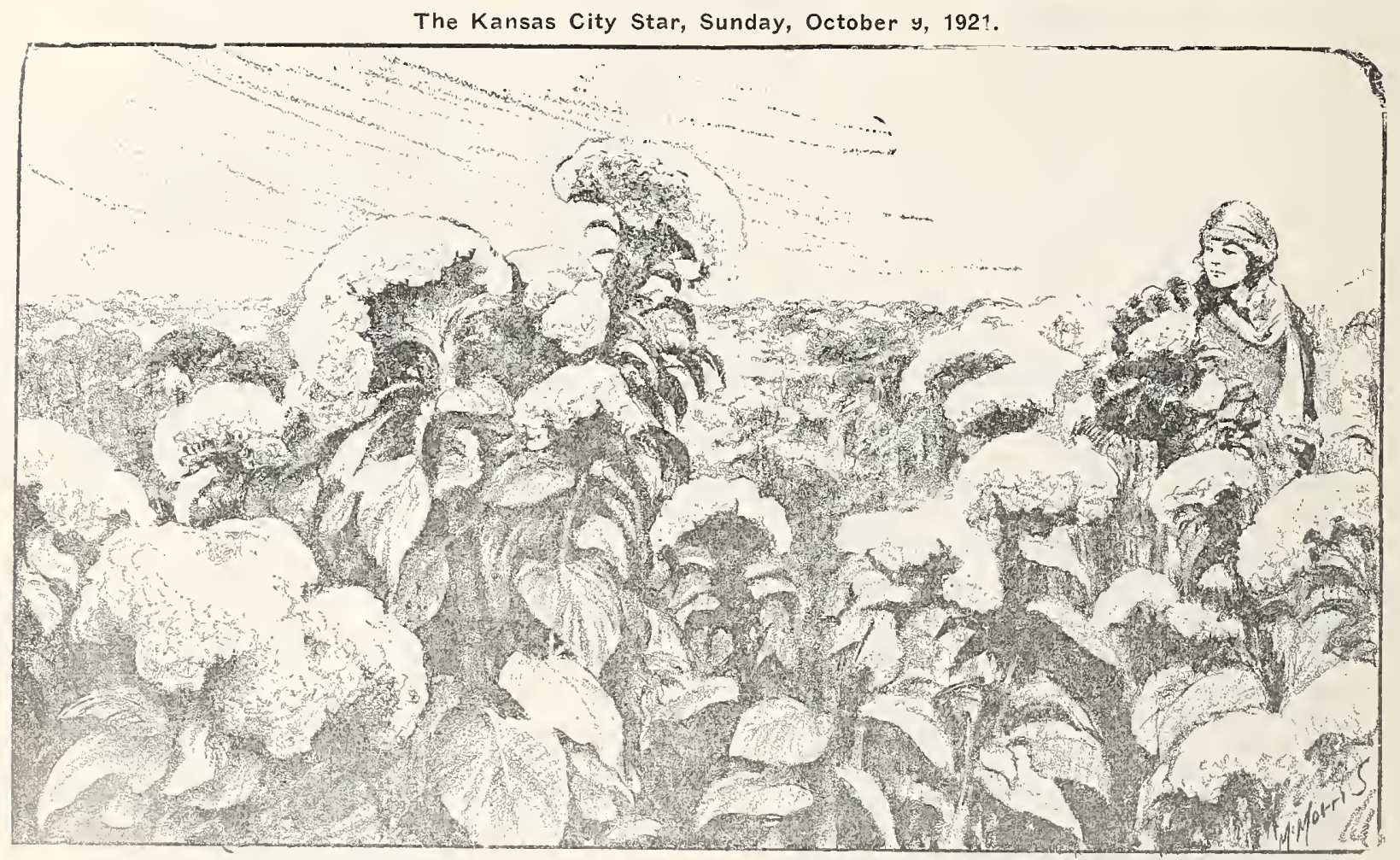

Mr. Ayres is known als for his development of sweet peas, some of the most choice varieties being his own originations. In the late winter months, his greenhouses at Sunny Slope. his farm near Independence are filled with vines sixteen feet high and covered with fragrant blossoms in errery ronceivable pastel tint.

CELOSIA CHRYSANTHEFLORA EASY TO GROW.

"CULTURAL DIRECTIONS FOR CELOSIA CHRYSA THEFL ORA"

Most any soil will grow CELOSIA CHRYSANTHEFLORA. Sow in a well pulverized sead bed out of doors about the first of May. When plants are about two inches high transplant into beds or rows, placing plants about three inches apart. Sometimes several flower stems appcal on one plant, and in this case if extra large flowers are desired disbudding is necessary. The stems of CELOSIA CHRYSANTHEFLORA grow from twenty-four to sixty inches long.

Nothing can equal CELOSIA CHRYSANTHEFLORA as a home, yard or garden decoration. They are in bloom throughont the summer and fall and the gorgeous colors are a source of wonder and delight to everybody.

\section{"DRYING OF CELOS'A CHRYSANTHEFLORA"}

The drying of CELOSIA CHRYSANTHEFLORA flowers is very simple. Just be particular to hang them upside down in a dark crol place and they will dry and retain their beauty and color indefinitely. Everyone who has seen CELOSIA CHRYSANTHEFLORA dried commends its usefulness very highly. It is beautiful in bouquets the year around.

SPECIAL RETAIL PACKET CELOSIA CHRYSANTHEFLORA mixed, price $\$ 2.50$ each, including; OId Rose, Salmon, Golden Wisteria, Shell Pink, Deep Red, Violet, Nulberry, Yellow, Lemon, Nile Green and Crimson.

SPECIAL RETAIL PACKE'T CELOSIA CHRYSANTHEFLORA and ARGENTEA. Mixed 50c each. This excels everything in CELOSIA, excepting only CELOSIA CHRYSANTHEFLORA. No one should be without this beautiful combination and our price is indeed very low for this Bryson Ayres Creation.

A limited amout of seed, fine mixture $\$ 2.50$ pkt. 


\section{FLOWER SEEDS-Cont.}

H) ACINTH IBEIN (Dolichos). Annual climber. Packet, 10c: large pateket, :

rocila. Fine strain. Isacket, toe.

l.ARkspur. Sunny Slope Giants. Pink, white, red, blut purple, lavender, cardinal, rose, carmine lilec. Separat purple, lavender, cardinal, rose, carmine lilac. Separ

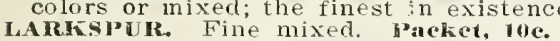

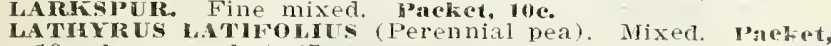
10c; large packet $205 \mathrm{~s}^{\circ}$

ISINARA MAIROCGANA. I'arket ror.

LI U M. I'acelet, 10e

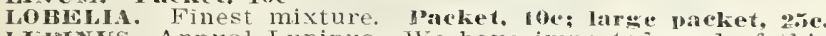
IUINUs. Annual Lupinus. We have imported seed of this valuable anumal from neally evely part of Europe. TF also have some wondertul American hybrids, these hare been grown very successially at our Sunny slope Farm. HUNNEIANNIA FUMARIAEOLIA. Called by some Tulip Poppy; very beautiful. Packer, 10e; larige bichet, añ.

MARIGOLD.

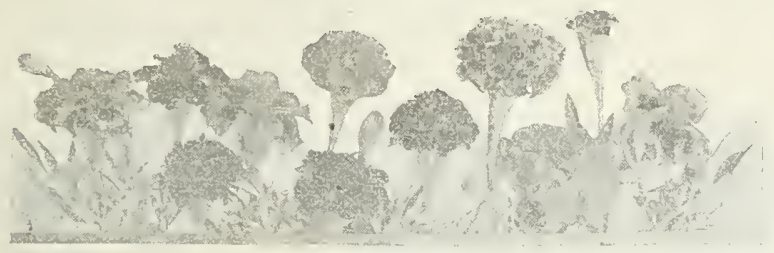

MATIGOID

IMRGOLID. One of Eryson Arres specialties TTe har obtained wonderful results in this beautiful old fashioned flowers. Tall African mixed. polket 16e: large foreket, $25 \mathrm{c}$

Separate colors in lemon or orange racerct.

MAREGORD. French Dwart. Double flowertd mixed,

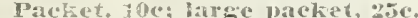

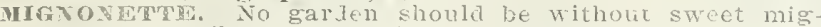
nomette. the flower of Shakespearean days pacuet ioe:

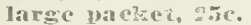

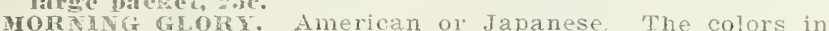
a fairy mixture. pactiet for: large parket. 23.

\section{NASTURTIUM.}

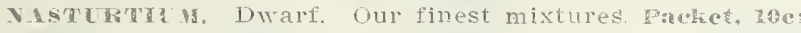

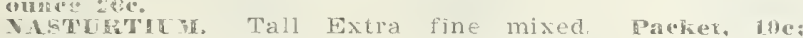
onuce, one.

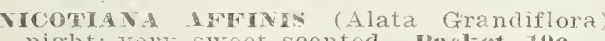

night; very sweet scented. Padict, doc.

Nitidid (Love-in-the-Mist). Packet, libe.

\section{PANSY.}

NAst. (Giant Sumny Slope Mixture); grown on our own tarms. This mixture contains the cream of the whole world. No better seed can be obtained from any source. All of these blooms are so large, ruffled and waved, that

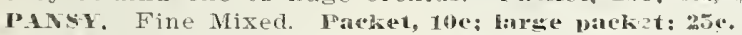

PEW IIA. Large flowered, Fringed and Double. Mixed. Packet, since.

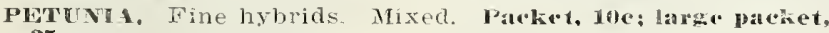

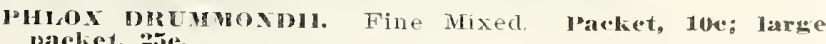

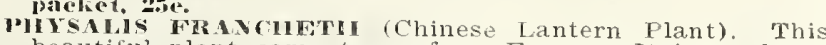
beautiful plant came to us from France. It is, perhaps, the most ornamental of all our ornamental flowers. The beautiful pods can be drit i, and make most beautiful winter bouquets. Facker, 3iv.

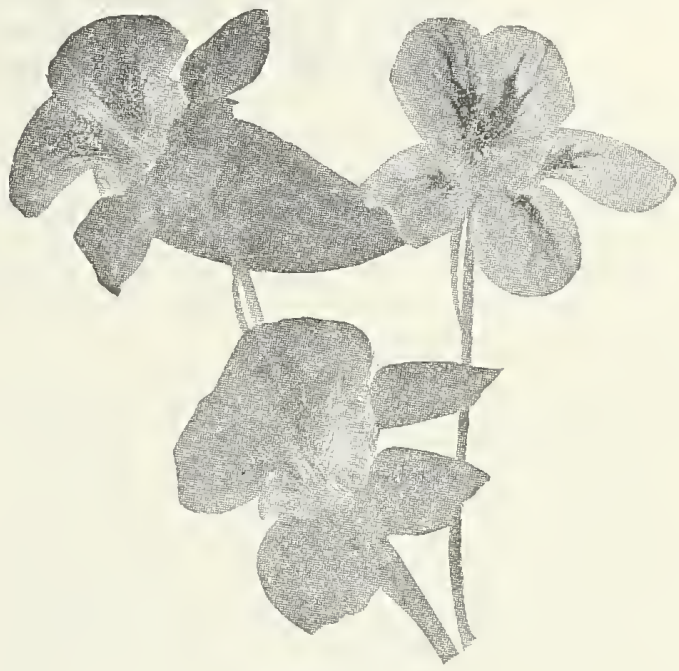

\section{POPPIES.}

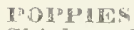

\section{Mixed. Conta}

ered. This seed was grown a

poppes. Annual Newport Pink.

opless. Annual Newport Pink. We obtained this from the originator. This beautiful poppy resembles a puge chrysanthemum, and is nost useful as a cut flower. Popplas. Oriental (Perennial). Fine mixed, including orange red, maroon and pink. palcket, 25e.

namertact. Fine mixed, Packet, 16e.

SALPTGLOSIS. Beautiful orchid-like flowers. Produces from early summer until fall. One of the best ammuals.

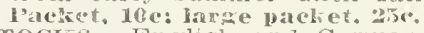

socrs. English and German mixed. Packet, 10e: large linelet, ase.

GTIAMLOWIRS. Mixed or separate colors. Wonderiul for winter bouquets. Packet, 15e; large packet me.

- LN WLowvir. Giant mixed, including red, yellow, cream. incket, $10 \mathrm{c}$.

SWRET WILdIA (Dianthus Barbatus). Mixed. Preker, toe: hatye gacket, ác.

I ERBENA. Pink, white, purple, scarlet, rose; separate colors or mixed. Packet, 10c; large picket, z5e; oz., $\$ 2.00$.

WALLFLOWER. This grand English flower should be more generally grown. Fint mixtule. Facket, roe: Imrge packet, 250.

\section{BRYSON AYRES ZINNIAS.}

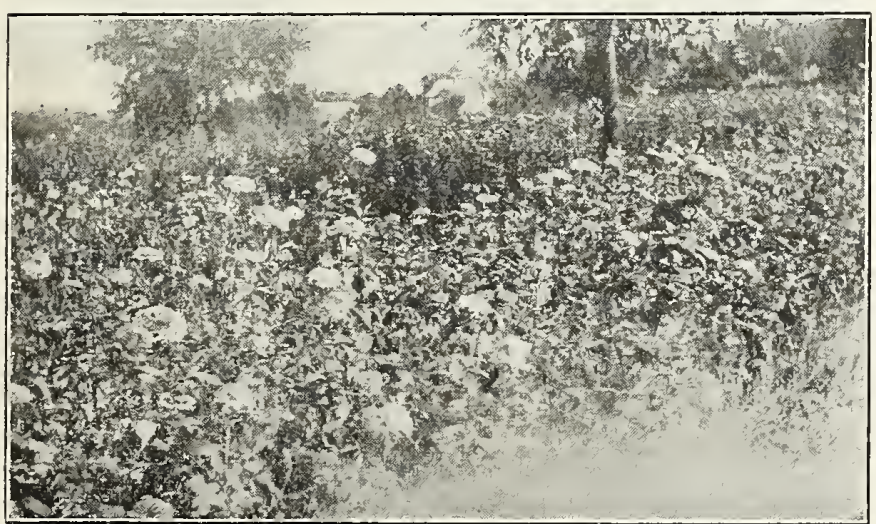

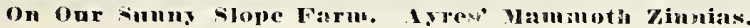

Jver one hundred different colors of Zinnias are grown on our Sunny Slope Farms.

WE ARE IMEIEICS HARGEGT ZINVIA GROWWRS.

ZINNA. Ayres Nammoth. We feel that our Giant strain is the finest in existence. Scarlet, white, crimson, purple, yellow golden primrose, salmon separate colors, Packet, ye. Fine mixed; packit lon: larse packet ac.

ZIVI. Dahlia Flowered Curled and crested. This grand novelty should be in every garden. Packet. lsc; larke bateket, 25ic.

GINNA. Dwarf (Little Red Riding Hood) Beautiful orange red. Packet, lic; large packet, 2.t. 


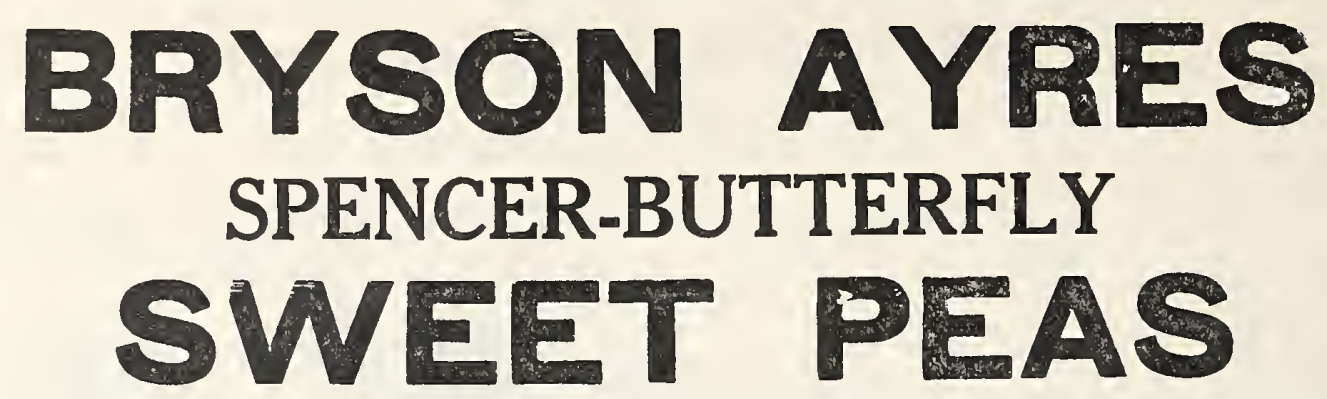

We are now recognized among the foremost authorities on Sweet Peas in the world. From the beginning, with a few rows of Sweet Peas, twenty years ago, Bryson Ayres has seen this humble start develop into one of the largest industries of its kind. Some of the world's choicest varieties are of the Bryson Ayres origination. We especially desire that you visit Sunny Slope during the late winter months and see Sweet Pea vines in our conservatories, 16 feet high, literally covered with orchid-like flowers, so sweet, so fragrant that one is thoroughly convinced that there is a "Sweet Pea Fairyland."

\section{AYRES SPRING OR EARLY-FLOWER- ING SPENCER SWEET PEAS}

These are the earliest flowering varieties of Sweet Peas in existence. Where the summers are hot, these varieties are best, as they bloom before the hot weather begins. They fully equal the standard or summer-flowering varieties in size and productiveness. but as yet have not the range of colors.

Price, All Collors, $1 / 2-0 z_{z}, 55 c ;$ oz. $\$ 1.00$;

$$
1 / 4=0 z ., \$ 3.50 ; 1 \text { lb., } \$ 11.00
$$

\section{WE OFFER FOR THE FIRST TIME \\ THESE BEAUTIFUL COLORS.}

PURE WhITE. Bold form. Extremely waved. CREAM. Wings hoftly amber tinted.

TIGHT INK. Wings of amoranth pink. Long stems. CREAM PIVI. Shaded with rose.

DEFI PIV Waved flowers, richly colored

ROSF Peautiful rosy carmine.

ul

ORANGi. Dazzling orange scarlet.

CRIMSON. Fiery red, perfect form.

CEris:. Charming shade of salmon cerise.

LAVIVDER. Beautifully waved and shaded.

LAVH

LIGH' ILUE. Large flowers long stems.
DARK BLUE. Large richly shaded blossoms

DA RK BLUE. Large richly shade

MAUVF. Beautiful rose lat. Deep rose purple.

MAROON. Rich red shaded dark purple.

AYRES SPECIAL MIXTURE.

A TRES BUTERTLY METD SPRING FLOWHEING. A mixture of all the spring flowering. Varieties listed herewith with additional 1.922 novelties.

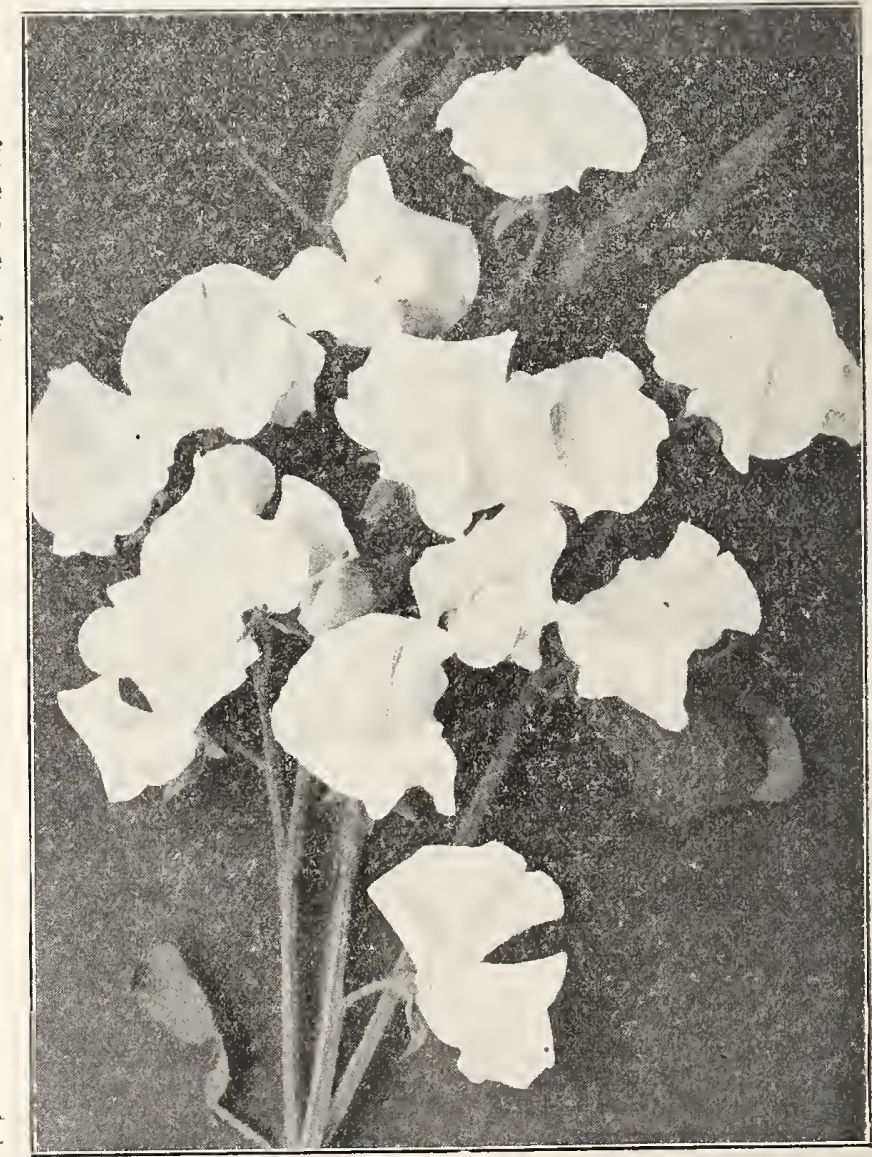

\section{AYERS STANDARD OR SUMMER-FLOWERING SPENCER SWEET PEAS}

\section{WE OFFER RE-SELECTED STOCKS FROM OUR SUNNY SLOPE FARMS}

\section{WHITE}

KING WhITw. The finest white; $1 / 2$ ox., 25e; or., 400.. 1/4 1b., $\$ 1.20$; $1 \mathrm{b.}$., $\$ 1.00$.

CONS'TANCE IIINTON. Black-seeded; 1/2 oz., 25e; oz., 40c; $1 / 411 ., \$ 1.20 ; 1 b ., \$ 4.00$.

\section{CIEAM}

FLORADALE FAIRY. Rich eream, duplex; 1/2 oz., 25e; oz., $400 ; 1 / 1$ lb., $\$ 1.20 ; 1 \mathrm{lb.} \$ \$ 1.00$.

ISAJWL. MALCOLM. Black-seeded; $1 / 2$ oz., 25c; oz., 40c: 1/4 Jb., $\$ 1,2\}$ : 11 ., $\$ 4.00$.

QUEWN VICTORIA SPIENCIR (IBCRPEE). Deep primrose, Flushed rose; oz., 40c: "/ lb., \$1.20: lb., \$4.00

\section{BI,USII}

ELEGA NCE. Blush-pink of largest size; $1 / \mathbf{z}$ oz., 55e; oz., $\$ 1.00 ; 1 / 4$ J3., \$3.00; Ib.. \$9.00.

AGIRICOLA. White, flushed lilac; oz., 40e; 1/4 1b., \$1.20; lb., \$4.00.

VALEN'TIN I. Light shell-pink; 1/2 oz., 35e; ov., 60c; $1 / 4$ tho $\$ 1.75 ; 1 \mathrm{~b} ., \$ 6.00$.

CHARM RUUSH. Shaded lilac; oz., 40c; 1/4 1b., \$1.20: 1b., \$1.00. 


\section{AYRES STANDARD OR SUMMER FLOW- ERING SPENCER SWEET PEAS.}

\section{WE OFFER RE-SELECTED STOCKS FROM OUR SUNNY SLOPE FARMS.}

LIGHT PINK
CARESS. Soft pink on cream. 1/2 o\%., \$1.00; o\%., \$1.50.

DAISYBUD. An improved Elfrida Pearson; $1 / 2 \%$ $\$ 1.00$ : $1 / 1$ ib., $\$ 3.00 ; 16 ., \$ 9.00$

ELFRIDA PEA SON. Deep blush-pink; 1/2 oz, 25e; o\%, 40e; $1 / 4$ lb., \$120; $1 \mathrm{l} . ., \$ 1.00$.

IIAVIS. Deep pink on white ground; 1/2 0\%., 30c; $0 \% .$, .0e; $1 / 4$ $1 \mathrm{b.s} \$ 1.510 ; 11 \mathrm{~b} ., \$ 5.00$.

cIS WRIGIIT. Fink on cream; oz., 40e: 1/4 1b., \$1.20; 120., $\$ 4.00$.

\section{CREAM-PINK}

BRIDESMAID. Rich salmon-pink on ivory-eream ground Packages only, Retail price, 25e each.

MARGA RET ATIEE. Deep pink on cream, suffused salmon; oz., 40e: $1 / 4$ llo., $\$ 1.20$; 1b., \$\$.00.

mes. HUGil Dicksov. Apricot-pink on eream; oz., 40e; $1 / 4$ Ib.. \$1.20; Ib., \$4.00.

IRS. ROUTYAH. Buff suffused delicate pink; or., 40e; $1 / 4$ ib., $\$ 1.20 ;$ lb.. $\$ 1.00$.

W. T. HUTCHINS. Creamy apricot-pink; oz., 40c; $1 / 4$ 1b., $\$ 1.20 ; 1 b ., \$ 4.00$.

\section{SALIION-PINK}

BERYL. Rich, soft salmon-pink, shaded buff; 1/2 oz., 25c;

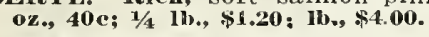

DORIS USHER. Salmon-pink on cream; oz., 40c; $1 / 41 \mathrm{~h}$. , $\$ 1.20$; Ib. \$4.00.

LILLIAN. Pale salmon-pink, suffused amber; oz,, 40c; 1/4 Ib., \$1.20; Ib., \$4.00.

PICTURE. Bright pink, flushed cream. Packets only. Retail price, $25 c$ each; $1 / 2$ oz., \$1.:5.

\section{DEIEP PINK}

ANNIE BOWNASs. Bright pink, heavily suffuserl salmon on white ground; oz, 40c; $1 / 4$ 1b., \$1,20; Ib., \$4.00..

COUNTESS SPENCRR. Soft rose-pink; oz., 40c; 1/4 Ib., \$1.20; 1b., $\$ 4.00$.

HAWLMARK PINK. Standard bright salmon-pink; wings rose-pink; 1/2 oz., 40c; oz., $75 \mathrm{c}$; $1 / 4 \mathrm{lb.,} \$ 2.50$.

\section{ROSE}

HERCULES. Rich pink, of magnificent size and form; o\%., 40e: $1 / 4$ Ib., \$1.20; 11 ., \$4.00.

DECORATOR. Rose overlaid with terra-cotta; oz., uoc; $1 / 4$ 1b., \$1.20; 1bv, \$4.00.

GEORGE HERBFRT. Bright rosy carmine; oz., 40c; 1/4 1b., $\$ 1.20 ; 1 b ., \$ 4.00$.

ROSARELLE. Large rose self with white blotch at base; ok., 40c; $1 / 41 \mathrm{lb} ., \$ 1.20$; 1b., \$1.00.

\section{SCA RLET}

MRS. C. F. TOMLIN. Rich, fiery scarlet; sunproof. Packets. Retail price, 25e each; 1/2 oz., 35e; oz., 60c: 1/4 lh., \$1.75; Ib., \$6.00.

VERMLLION BRILLIANT. Intense scarlet self; oz,, 40c; $1 / 4$ ll., \$1.20; $1 \mathrm{lb} ., \$ 4.00$.

\section{LAVINDER}

DON ALVAR. Soft silvery blue; oz., 40e; 1/4 lb., \$1.20; lb., \$4.00.

HAWLMARK LAVENDElR. True, clear light lavender: 1/2 oz., \$1.75; o\%., \$2.00.

FLORENCE NIGHTINGAIA. Clear lavender with rose-pink sheen; oz., 40e; $1 / 4$ lb., \$1.20; $1 \mathrm{~b} ., \$ 4.00$

MARGARET MADISON. Azure-blue self; oz., 40c; $1 / 4$ lb., $\$ 1.20$; lb., $\$ 1.00$.

ORCIID. Deep lavender, suffused pink; 1/2 oz., 25e; oz.., 40c; $1 / 4$ lb., \$1.20; 1b., \$1.00.

R. F. FELTON. Lavender, suffused mauve; oz., 40c; $1 / 4 \mathrm{lh.,}$ $\$ 1.20 ; 1 \mathrm{~b} ., 8+1.00$.

\section{HLUE}

MrS. TOMI JONES. Bright Delphinium-blue; 1/2 oz., 55c; oz., $\$ 1.00 ; 1 / 4$ lb., \$3.60.

PHANTON BLUE. A pastel shade of blue; oz, 40c: 1/4 1b., $\$ 1.20$; $1 \mathrm{~b}$. \$4.00.

WEDGWOOW. Deep azure-blue; ox., 55e; 1/4 1b., \$1.75; Ib.,
DARK RIUE BLUL MONARCH. Extra large, dark blue self; oz., 40c; $1 / 4$
lb., \$1.20; lb., \$4.00. THIE LADY EVEI.INE.
Ib., \$1.:0; 1b., \$4.00. MAUVE:

Beantiful rosy mauve: oz., 40r; $1 / 4$ PURPI,E

ROYAL. PUIPLE. Rich, warm purple; oz., 40e; 1/4 1h, $\$ 1.20$; Ib., \$4.00

IIThUhe GREWN. Claret colored self; oz., 40e; 1/4 1b., \$1.20;

Ib. \$4.00. Rose-crimson with a soft salmon suffusion.
ROSALIND. Ron packets, 250; $1 / 2$ oz, si.tio.

\section{SAIMON}

1:ABAR. Large salmon-orang*e self; $1 / 2$ oz., 25e; oz., 40c;

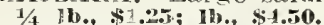

STHPUING S'Tuiv'. Deep salmon, suffused orange; ox, 40e; 1/1 lb., \$1.20: $1 \mathrm{l}$, ., \$1.00.

OR.A NGI:

HELEN LFWIS. Standard crimson-orange; wings orangelose; rz., 10e; $1 / 2$ llb., \$1.20; $1 \mathrm{b.}, \$ 1.00$.

ROBER'T SYDENHAM. Glowing orange self; 1/2 oz., 3Je: $n \%$, 60 e: $1 / 4$ 1lb., \$1.75; $1 \mathrm{b.,} \$ 5.00$.

TANGER ING. New, deep orange; 1/2 oz., 40e; az., $75 \mathrm{c} ; 1 / 1 \mathrm{lb.}$ S.2.2.5.

THE PRESIDENT. Dazzlíng orange-scarlet; oz,, 50c; $1 / 4$ Ilb., \$1.25; $1 \mathrm{~h} ., \$ 5.00$.

THOMAS STEVENSON, IMPROVED. Standard orange: wings rosy scarlet; $1 / 2$ oz., 35c; oz., 65e; $1 / 41 \mathrm{~b}, \$ 1.90 ; 1 \mathrm{~b}$., $\$ 60.00$.

\section{CERISE}

FIERY CIROSS. Bright orange-cerise; oz., 60c; $1 / 4$ Ib., $\$ 1.80$; $1 \mathrm{b.,} \$ 5.50$.

HoPN. Scarlet-salmon-cerise self; 1/2 oz., 30c; oz., 50c; 1/4 Ib., \$1.50; $1 \mathrm{b.}$. \$5.00.

ILEUMINA'TOR. Rich, cerise-salmon; oz, 25e; 1/4 lb., \$1.\$0; Th., $\$ 4.00$.

INCHEITi: Cerise self; largest size; or., 40c; $1 / 4$ Ib., $\$ 1.20$; Ilo., \$4.00.

KIXG: EDWNRD. Deep carmine-crimson; oy., 40e; $1 / 4$ lb., $\$ 1.20 ; 1 b ., \$ 4.00$. $\$ 1.75 ; 0 \% . \$ 3.00$.

S5 Deep chocolate-maroon; 1/2 oz., 50c: oz.. S5c: $1 / 41 \mathrm{~b} ., \$ 2.80 ; 1 \mathrm{~b} ., \$ 9.50$.

Alt 1b., $\$ 1.20 ; 1 b . \$ 1.00$.

\section{AHT SHADES}

BROCADE. ISatiny salmon, lavender and rose-pink; 1/2 oz., 35e; oz., 60c; $1 / 41 \mathrm{~b}, \$ 1.75 ; 1 \mathrm{~b} . \$ 5.50$.

Charces Foster. Hydrangea pastel shades; oz, 40e; 1/4 lb., \$1.20; 1b., \$4.00.

IRISIY BELLE. Lilac flushed pink; oz., 40c; $1 / 4$ 1b., \$1.20; Ib., \$4.00.

PRINCE GEORGE. Pastel rosy lilac; oz., 40c: $1 / 4$ lbo, \$1.20; $1 \mathrm{b.,} \$ 4.00$.

ROSINA. Rich rosy heliotrope; oz., 40c; 1/4 lb., \$1.20; 1 b., $\$ 4.00$.

CoNSTANCE AComB. Creamy white, suffused mauve; oz, 40c; $1 / 4$ lb., \$1.20; $1 \mathrm{b.g} \$ \$ 4.00$.

\section{PICO'TEE}

CHERU13. Rich eream edged with bright rose; oz.., 40e; $1 / 4$ 1b., \$1.20; 1b., \$4.00.

DAIN'TY. Pure white, edged with rose-pink; oz., 40c; $1 / 41$ lh., $\$ 1.20 ;$ ib., \$1.00.

IEAN IREIA N1. Cream, picoteed rose; oz, 40e; 1/4 th., $\$ 1.20 ;$ Ib., \$1.00.

MRS. A. G. GLNTLE. White, edged scarlet; ox., 40e; 1/4 lb., $\$ 1.20$ : $110 ., \$ 4.00$.

IRS. J. BALMEK. Cream, suffused reddish pink; oz., 40c; 1/4 1b., \$1.20; 1b., \$1.00。

IRS. 'TOWVNSEND. White with picotee edge of blue; oz., A0c; $1 / 41 \mathrm{~b}$., \$1.20; $1 \mathrm{b.}, \$ 4.00$.

IRS. FRED KEl, T. Thite with narrow edge of violetblue; oz., 40e; $1 / 4$ lb., $\$ 1.20$; 1 b., $\$ 4.00$.

\section{AYRES SPECIAL MIXTURE.}

AYRES BUTTERFLY MIXED. A mixture of all the summer flowering varieties listed herewith with additional 1922 novelties, the finest mixture; 1/2 oz., 25e; oz., 40e; 1/4 1b., $\$ 1.210 ; 1 h ., \$ 4.00$.

\section{CULTURAL DIRECTIONS—SWEET PEA GROWING A PLEASURE}

It is easy to grow Sweet Peas and almost any soil will grow them. Spade the ground deep, then add to soil, if convenient, commercial fertilizer (such as pulverized sheep manure) or the well rotted product of the barn yard. Mix well with soil, being careful to pulverize all clods. Dig trench from 4 to 6 .inches deep and sow seeds thickly, covering them with about 1 inch of soil. For a row 50 feet long, use 1/4 pound of seed. After plants are about an inch high, begin to cultivate and support with string, wire netting or brush, or, if planted along a woven wire fence, no support is needed. When in blossom, pick the flowers daily, as this prolongs the blooming season. 


\section{SUMMER BULBS}

The Florist, as well as the Landscape Gardener, will find much of interest in the following lists. Ayres' Bulbs are selected with the same care and attention to Quality as are Ayres' Seeds. All of the bulbs and roots offered herein are first size (unless otherwise stated), sound and healthy, and sure to bloom if given reasonable care.

We take particular pains in speciaily packing bulbs and roots to ensure their arrival in good condition and, for this reason, always ship bulbs separately from seeds when both are ordered. When placing your order, specify when and how you wish your bulbs to be sent.

Our collection of Dahlias is especially worthy of attention. Our lists of bulbs are not so extensive but are carefully selected and comprise the best varieties for all purposes; in fact, it has been our aim throughout to offer Quality rather than Quantity.

Note-Three or more bulbs will be supplied at the dozen rates, 25 or more at the 100 rates, and 250 or more at the thousand rates.

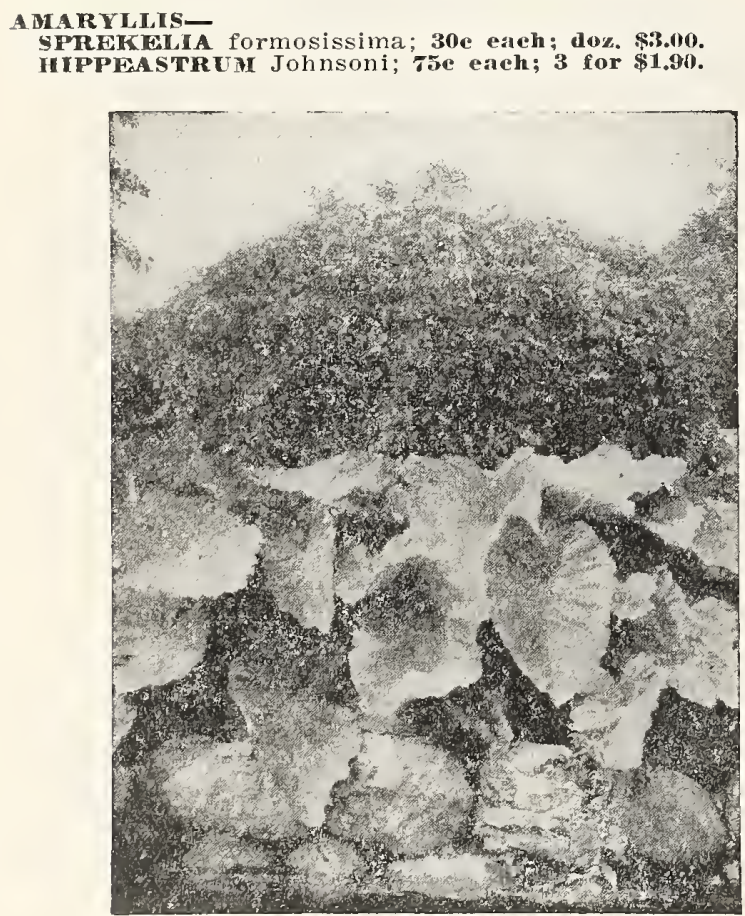

CAI.ADIUM

CALAUTUM Esculentum Elephant's Ear (Colocasia); 9 to 11 inches; 30e each; 6 for $\$ 1.35$.

\section{CANNAS}

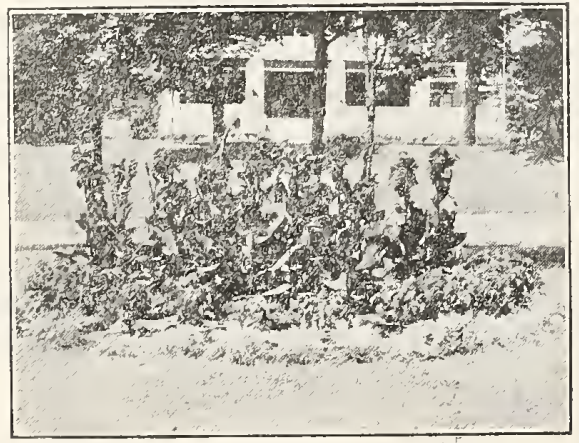

CANNAS

"Whe Fimest Five"City of Portland; :30, each; doz., \$2.75; per 1010, \$\$18.00. Favorite; 20e each; do\%. \$1.60; per 100, \$10.00.

King Humbert: 20e eâch; eloz., \$1.50; per 100, \$9.70.
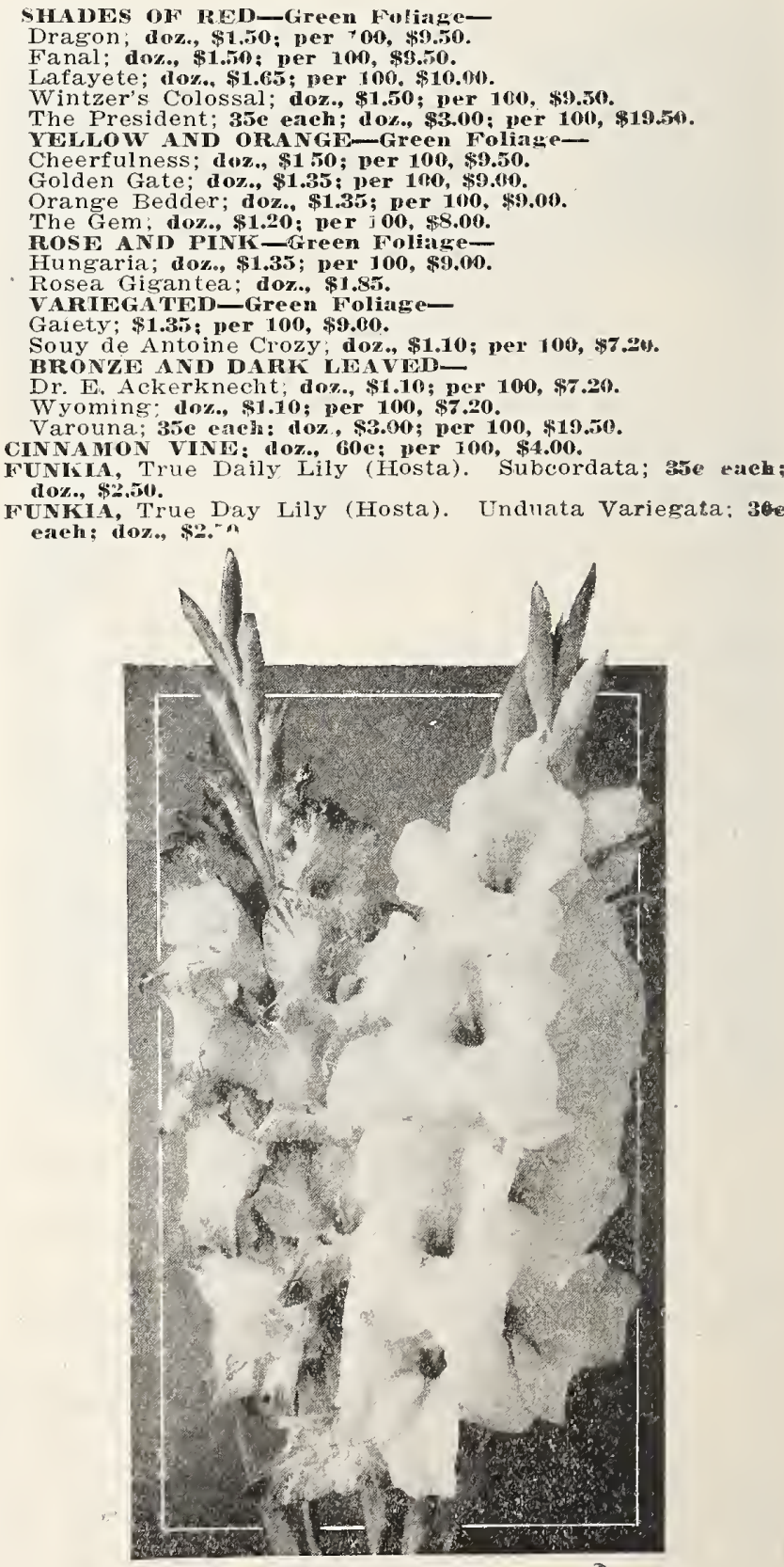

IYRES GIANT GLADIOLI 


\section{GLADIOLI.}

Ayres' New Primulinus Hylorids

The most graceful in form profuse in bloom, and artistic in color of all Gladioli. They have made a sensation wherever they have been exhibited and will be in tremendous demand for cut flowers. 3 for 250 ; 6 for 250.

STANDARD VARIETIES-

America, Pink: doz. Gic: per 100, S4.50.

Baron Hulot Blue; doz.s s1.50: per 109, s9.50.

Halley. Orange red; doz. Soc; per 100, 85.75.

Kunderai Glory. Ruffled cream; doz., be: per 100, \$6.2.5.

Mrs. Frances King. Scarlet; loz., 6.te; per 100, \$i,no.

Mrs. Frank Pendleton, Jr. Pink and red; doz.. s.ie; per 100, \$s.00.

Mrs. Watt. Cherry red; doz., 90c: per 100, \$6:25.

Niagara Rose calmine marking; loz., 90: per 100, \$6.2.5. Panama. Deep pink; loz., \$1.35; per 100, $\$ 9.00$.

Peace. Large white; doz., 90c: per 100. \$\$6.:5.

Princepine. Scarlet: doz. 106: uer 100, 36.25

Schwaben. Canary yellow; dow. \$1.50; per 100, \$9.50.

GLADIOLI IN MIXTURE-

Fine Mixed. First size; loz., boc; per 100, \$3.50.

Fine Mixed. Second size; per 100, $\$$, 00 ; per $1,000, \$ 1 \$ .50$. Special Light Shades, mixed; doz., tse; per 100, \$4.09.

HEMEROCAILIS. Lemon Lily. Flava; 20e each: 3 for 5oe.

HEM FRocallis. Golden Lily. Florham; 20e each; 3 for 50e.

\section{HARDY LILIES.}

AURATUh. Crimson and yellow. Fach 30e; a for st.mo. HA NSO NI. Yellow. Wach sue; 3 for $\$ 2.00$.

HENRYi. Apricot. Each Soe: 3 for $\$ 2.00$.

LONGIFIor UMI GIGANTEC y. White. Each toc; 3 for $\$ 1.00$.

SPECIOSUM Melponeve. Crimson. Wach foe: 3 for $\$ 1.00$.

SPECIOSUM RoIredi. Deep rose. liach doe: 3 for $\$ 1.00$. TIGRINUM FOIRTNEL GIGINTEIM. Each 40e; 3 for $\$ 1.00$.

TIGRINUM FLOHE PELVO; eateh 400 ; 3 for $\$ 1.00$.

HIY OF "THE: VALIEY. Field grown clumps. Divided; doz., 75e.

MADEIRIA VINE, Dnz., ZT.

MONTBR ETIA. Crocosmiaeflora. Mixed colors. Dux., \$1.50,

\section{TUBEROSE.}

TUHERosw. Excelsior Pearl. Double. First size; doz., 6oe Ter 100, sh.so.

TUMEROSE. Single. Dox., tinc; per 100, \$.00.

Note-Three or more bulbs or roots will be supplied at the dozen rates; 25 or more at the 100 rates, and 250 or more at the 1,000 rates.

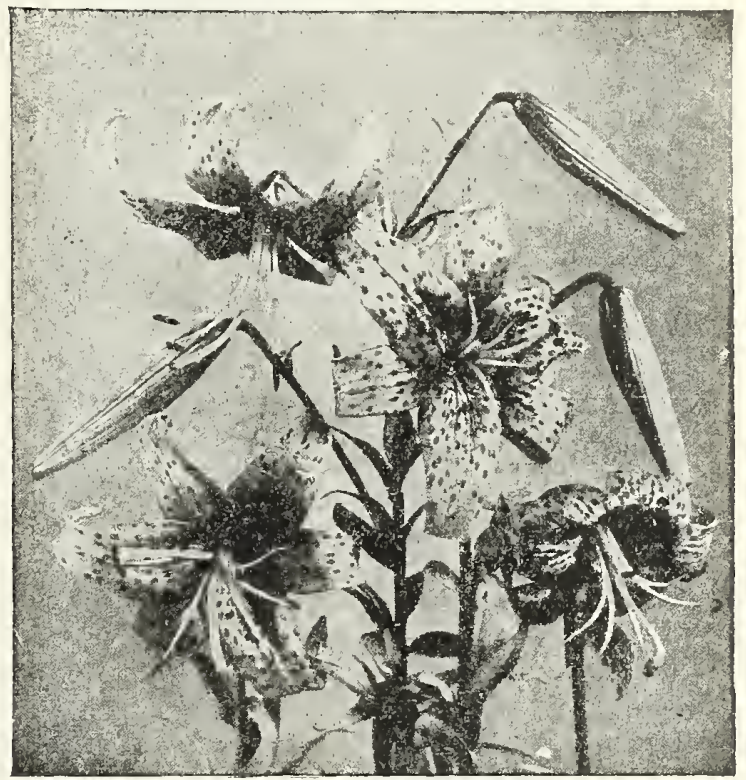

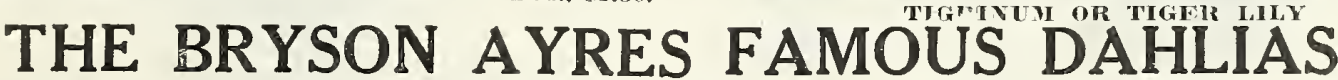

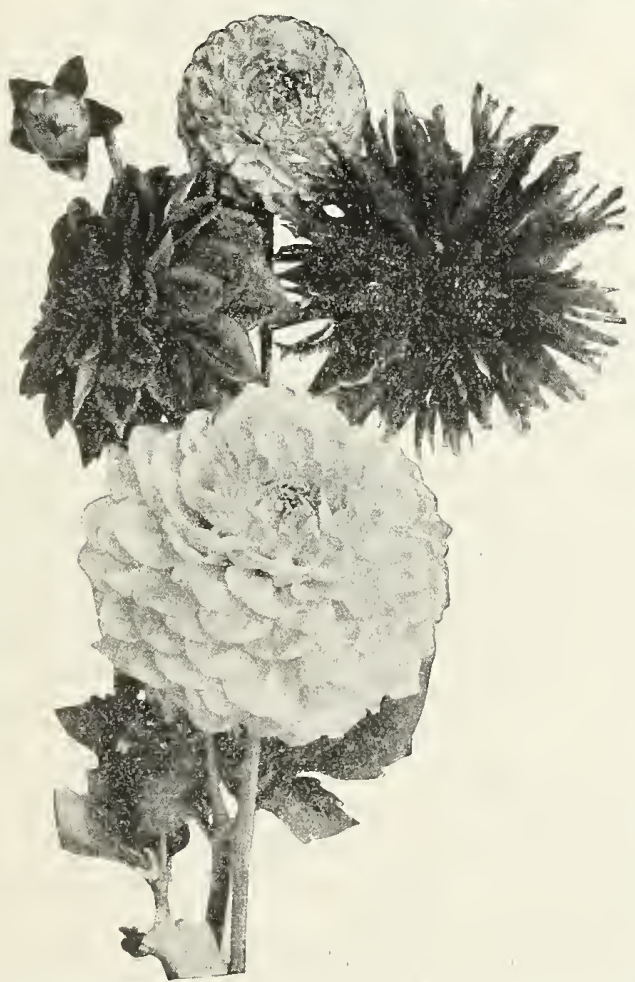

CHOICT, CN-FLOWERED DAHLIAS

SUNN SIOPE CREAM. Large and free-blooming. Cream red; suffused with salmon and yellow. Very free-flowerred; suffused with salmon

SUNNY SLOPE CREA. L. Large and free-blooming. Cream, suffused yellow; 30c cach: doz., \$3.00.

SUNNY SLOPL SALION. Salmon, suffused yellow and amber; 30s each; doz, \$3.00.

SUNNY SLOPE WHITE. Magnificent, pure white flowers of giant size, borne continuousiy on long stems well above the foliage; 250 each: doz.. \$2.ño.
11. I. LOVINIK. A delicate combination of white and lilac. large flowers on exceptionally long stems; zse each: do\%., $\$ 2.50$.

IORTULANUS BUDDE. Orange-scarlet, shading lighter toward the edges of the petals, with a glistening bronze or copper sheen:45c cach doz.s400.

JoHN D. ROCKFFELCER. Pinkish salmon-buff. Very early and free-flowering; 30c each; doz., \$3.00.

MHS. HUGH DrCKsox. Exquisite rich salmon, suffused with light buff-pink: 30c each; doz., \$3.00.

MRS. WV. W. WHINIR ir. A lovely rose, suffused clear yellow, deepening at the base of petals: 30c each; dox., 83.00 MFS. JOEN GIIBHEL. Light salmon-pink, heavily flushed andocr and vellow; 30e each; doz., \$3.00.

MME. VON BISTEIN. Large, elegantly formed blooms. Soft mauve shading lighter toward the outer edges of the petals: 15e. $1 / 4$ do\%

RO NOLO IARZANI. Farly and free-flowering.

lightful blend of rose, salmon, and amber. Splendid for cutting: 30e each; doe, \$3.00.

THE BHIDE. White with a blush suffusion toward the center. The petals are much twisted and gracefully curved; $45 \mathrm{c}$ cacli: $1 / 4$ doz., $\$ 1.25 ;$ doz., $\$ 1.00$.

HORTUIA NS WHITh. , Very large, flee-flowering, pure white; tre each: 1/4 loz., \$1.25; doz., \$4.00.

BAIRONG. DE GRA MCV. Pure, waxy white of perfect form. A profise bloomer; zac each; doz., \$\$.50.

IPEONY-FLOWERED DAHLIAS IN MIITURE; 100 TOH $\$ 7.00$ doz., $\$ 1.15$

SELECT DECORATIVE DAHIMAS

IYcsift. Clear, light yellow of largest

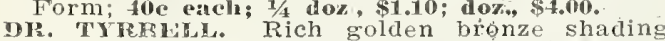

DI. 'TYRELILl. Rich golden bronze shadin
red at base of petals; s5e each; doz., \$2.50.

HoRTULA Nos HE'T. Rich salmon, suffused amber and

yellow. Flowers of immense size $55 e$ cach: $1 / 4$ doz.. $\$ 2.00$ JACK ROsw. Brilliant crimson-red. Well establishea in popularity; zoc each; doz., \$2.00.

JOIN WANAMALWR. Deep lavender-pink. Very free-flowering; 45e eacls; $1 / 1$ doz., $\$ 1.25$; doz., $\$ 4.00$.

MELODy. Canary-yellow petals tipped with creamy wite Of large size; 20c cach: doz., \$2.00.

MIVNIE BLRGLE. The finest red. Of large size, free.

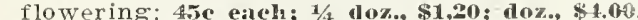

MIVNIE MCCULIOUGH. Soft golden yellow, tipped bronzy

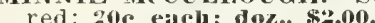

red; 20 each: doz., Szoo. Large flowers in profusion; 45c each; 1/1 doz.s $\$ 1.20$; $10 z$. $\$ 4.00$

ORANGE BWAUTY. Deep, rich orange-an unusual shade: 45e each: $1 / 4$ doz., \$1.25; doz., \$4.00.

YGLLOW GIANT (Jan Olieslagers). Rich, buttery vellow. Very free-flowering; 30e each; doz., \$3.00.

AYIRS, TRIAL GROUNI MIXTURE. Each 15, Do\%, s1.25. 


\section{LANDSCAPE DEPARTMENT ORNAMENTAL FLOWERING SHRUBS}

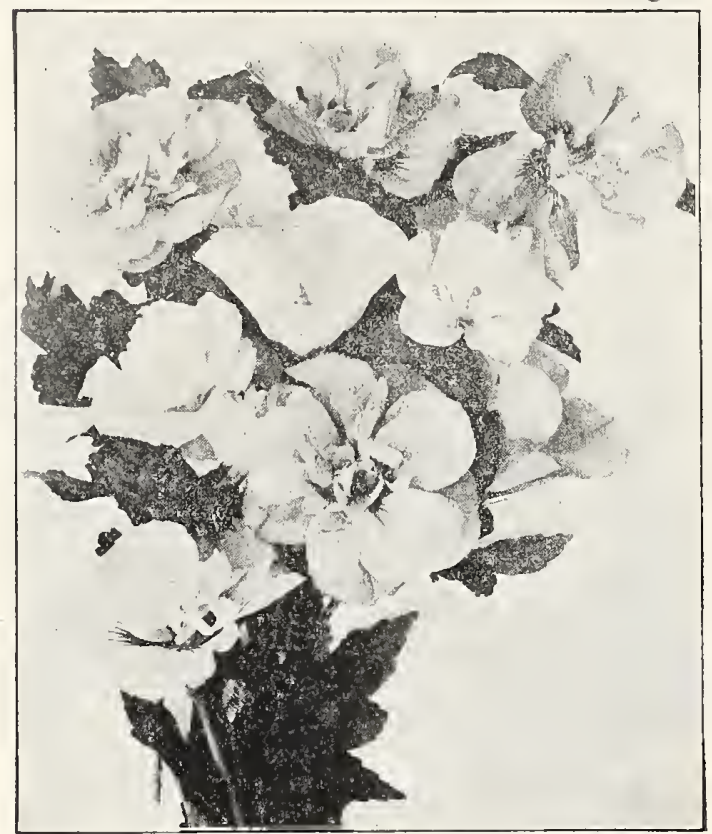

ALTHEA'S BLOOM THROUGHOUT SUMMER AND FALL

ALTILA. Rose of sharon, all colors, 2 to $3 \mathrm{ft}$. Each 750. Specimen Shrubs, \$1.50 to $\$ 6.00$ each.

ALMonD. Double flowering. Pink or white, 2 to $3 \mathrm{ft}$. \$1.50 Each.

GARERRRy, THUNBEIK's (Japanese Barberry). 2 to $3 \mathrm{ft}$. Each 75e. Specimen plants, \$1.00 to \$2.50.

BUTTRRTLY BUSH (Buddliea). 2 years old. Each 75e; 4 years old. Wach \$2.00.

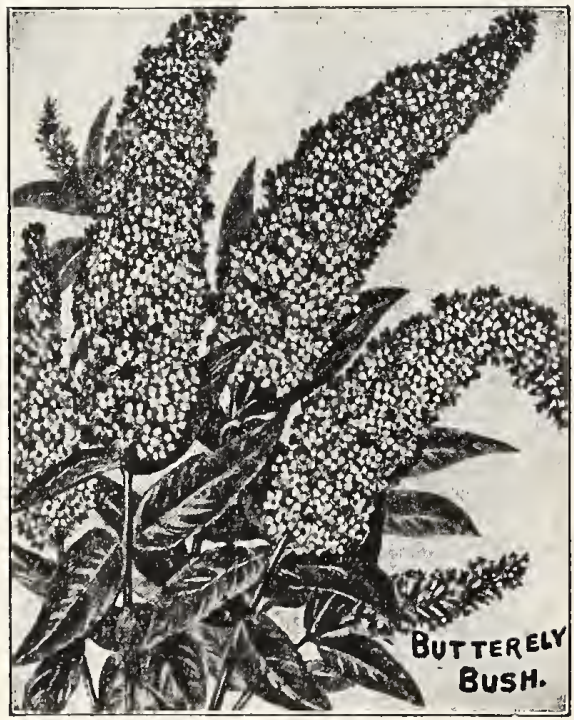

Curmant. Flowering, 2 to 3 ft. Each 75e. Specimen Shrubs, \$1,50 to $\$ 3.00$.

CRAB. Double flowering. Beautiful double pink flowers like tlny roses, 2 to $3 \mathrm{ft}$, \$1.50 Each; 2 to $4 \mathrm{ft}$, $\$ 2.50$ each. CALYCANTHAS (Sweet Shrub), 2 to $3 \mathrm{ft}$. Each $\$ 1.50$.

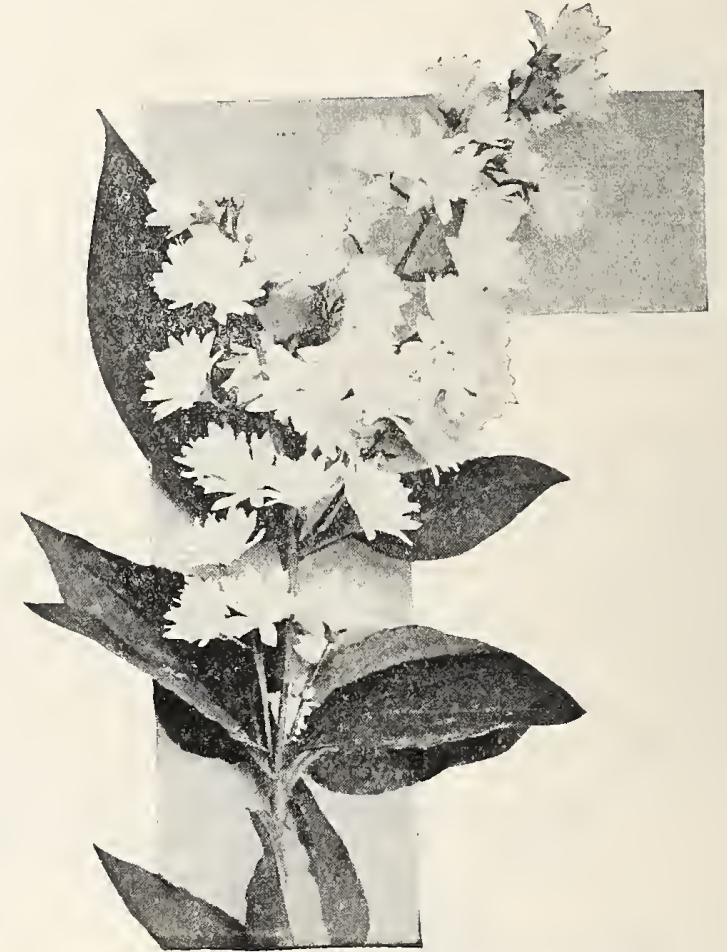

DEU'LAA, PHOL' OF ROCHESTER

DEUTZIA GRACILIS. A neat, dense little bush, rarely over 2 feet high, that blooms in May, wreathing its drooping branches with pure white flowers. Equally valuable for shrubberies and forcing. Fine for growing in fiont of taller shrubs. 18 to 24 inches, each $75 e$ :

DEUTzIA PRIDE OF ROCHESTER. 18 to 24 inches, Each 75e. Specimen shrubs, $\$ 1.50$ to $\$ 2.50$.

DoGWoOD. Red twigged (Cornus Sibirica alba). 3 to 4 ft, 80c. Specimen shrubs, \$1.50 to \$3.00.

DESMODIUI. Graceful drooping flowers in late autumn: each $\$ 1.00$.

ELCAGNUS LONGII.gs. Edible red berries. 2 to $3 \mathrm{ft}$; $\$ 1.00$ each. Specimen shrubs, $\$ 2.00$ to $\$ 4.00$ each.

TICANS AUGUSTFOLIA. Silver leaves and yellow flowers. Specimen shrubs, \$1.50 to \$4.00.

ELDER. Cut-leaves (Sambucus Nigra Liciniata). 2 to 3 ft.60e; Specimen shrubs, $\$ 1.50$ to $\$ 2.00$.

Forsy'rut SUSPENSA (Golden Bell). 2 to $3 \mathrm{ft}$, each 60c. Specimen bushes, \$1.50 to \$3.00.

FRINGE. Purple or Mist Tree (Rhus Cotinus). Specimen shrubs, \$1.00 to \$2.00.

ERINGE. White (Chionanthus Virginica). 3 to $4 \mathrm{ft}$, 80e; Specimen shrubs, $\$ 2.00$ to $\$ 3.00$.

\section{BUSH HONEYSUCKLE}

HONEYSUCKIE. Frasrant. 2 to 3 ft., 75e. Specimen shrubs, \$1.50 to $\$ 5.00$.

MONEYSUCKLE. Ledebour. 2 to $3 \mathrm{ft}$, 75c.

HONEYSUCKLE. Red Tartarian. Specimen shrubs, $\mathbf{\$ 1 . 5 0}$

to \$oN RYSUCKLE. Pink Tartarian. Specimen shrubs,\$1.50 to

HONEXSUCKLE. Morrow's (Lonicera Morrowi). 2 to 3 ft., 75e. Specimen shrubs, \$1.00 to \$10.00.

Hores-Chestret. Dwarf (Aesculus Parviflora). 18 to 24 inches, \$1.50.

HYDI A VE. Large-flowered (Hydrangea Paniculata Grandiflora). $3 \mathrm{ft}$., \$1.00. Specimen shrubs, \$2.00 to \$3.00.

HYDRANGEA. Tree, Same as the former, but grown in tree form, and bears great trusses of flowers. Specimen shrubs, \$1.50 to \$3.50.

ITULA NGEA. Arborescens Grandiflora (Everblooming YDIRANGEA. Arborescens Grandiflora (Everblooming $\$ 2.00$ to $\$ \$ 3.00$. 


\section{Ornamental Flowering Shrubs}

\section{LILACS.}

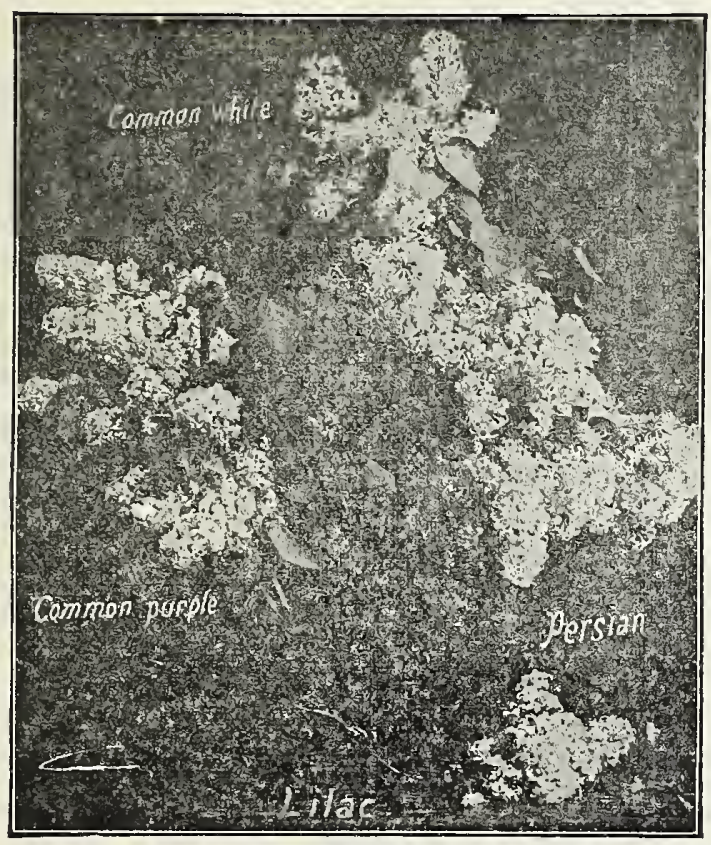

A YRES LILACS

LILAC. Common Purple (Syringa Vulgaris). 2 to $4 \mathrm{ft.}$ 80c. Specimen shrubs, \$1.50 to $\$ 6.00$.

LILAC. Common white (Syringa Vulgaris Alba). 3 to 4 ft., 80c. Specimen shrubs, $\$ \mathbf{1 . 5 0}$ to $\mathbf{\$ 6 . 0 0}$.

LICAC. White Persia (Syringa Persica Alba). 2 to 3 ft., 80c. Specimen shrubs, \$1.50 to \$6.00.

IILAC. Giant Tree (Syringa Japonica). 2 to $4 \mathrm{ft.}$ 80e; LILAC, HIMALAYAN (Syringa Villosa). 3 to $4 \mathrm{ft.,} \$ \mathbf{\$ 1 . 2 5}$. \$1.00. Specimen shrubs, \$1.50 to \$6.00.

LILAC, HIMA LAYAN (Syringa Villosa). 3 to $4 \mathrm{ft.}$ \$1.25. Specimen shrubs, \$1.50 to $\$ 6.00$.

NAMED FRENCH VARIETIES OF LILACS. The named sort ate much superior to the old type of Common Purple and White and bloom much earlier. 2 to $4 \mathrm{ft}, \$ 1.25$. Specimen shrubs, $\$ 2.50$ to $\$ 5.00$.

ALPHONSE LAVELLEE. Fine blue, shaded violet.

BELLE DE NANCY. Satiny rose; white center.

CHARLES $\mathbf{x}$. Reddish purple; large.

DR. MA STERS. Clear lilac; superb.

IUDWIG SPA ETH. Dark purplish red; superb.

MAIRE LFGIRA YE. One of the finest white Lilacs.

MICHAEL BUCHNER. Dwarf; pale lilac.

MADAME LEMOINE. Fine, double. white lilac.

PRESIDENT CARNOT. Pale blue.

PRESIDENT GREVY. A beautiful blue.

PRESIDENT VIGER. Bluish lilac; extra.

RUBRA DE MAKLY. Purplish red; fine.

LoCUST, PINK, (Robinia Hispida). 2 to $4 \mathrm{ft.}, \$ 1.00$. Specimen shrubs, \$1.50 to \$3.00. PLUM. Double-flowering (Prunus Triloba). 2 to 4 ft.,
$\$ 1.50$. Specimen shrubs, $\$ 2.50$.

PIRIVET, REGEL'S (Ligustrum Regelianum), 2 to 3 ft., $35 c$ in lots of 25 or more. $4 \mathrm{ft}$., $60 \mathrm{c}$ each in lots of 25 or
more.

PIEIVET IBOTA (Ligustrum Ibota). 2 to $3 \mathrm{ft.}$, 35e each in Iots of 25 or more. 4 ft., 60 each in lots of 25 or more. Specimen shrubs, $\$ 1.00$ to $\$ 2.00$.

PRIVET, AMOOR RIVIGR NORTH (Amurenee). Best adapted for this altitude, $2 \mathrm{ft}$. 200 each In lots of 25 or more. 2 to 3 ft., 25 c each in lots of 25 or more. 3 to $4 \mathrm{ft}$., $40 \mathrm{c}$ in lots of 25 or more. $\underset{\$ 1.00}{\text { QUICE, JAPAN (Cydonia Japonica). Speclmen shrubs, }}$

SIHEIRIAN PEA TREE (Caragana Arborescens). 4 to $5 \mathbf{f t .}$ $\$ 1.25$. Specimen shrubs, \$1.00 to $\$ 5.00$.

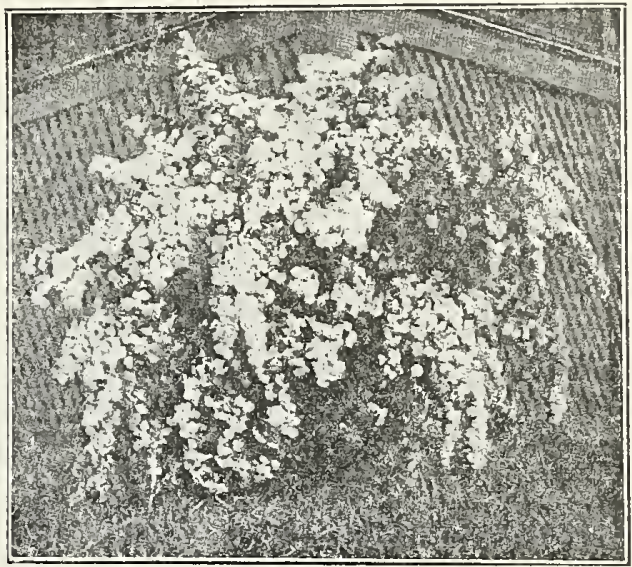

SPIRAEA V. H. BRIDAL WREATH

SNOWBALL, CARLES' (Viburnum Carlesli). 2 to $3 \mathrm{ft.,} \$ 1.00$. 3 to $4 \mathrm{ft}$., $\mathbf{\$ 1 . 5 0}$.

SNOWBALL. Common (Viburnum Opulus Sterile). Specl. men shrubs \$1.00 to $\$ 5.00$.

SNOWBALL WAYFARING TREE (Viburnum lantana). 3 ft., 75e. Specimen shrubs, $\$ 1.50$ to $\$ 5.00$.

SNOWHALL, HIGH-BUSH CRANBERRY (Viburnum Opulus). American type. Quite different from the regular type; leaves glossy green with red steams and are free from insects. 4 to 5 ft., \$1.25. Specimen shrubs, \$2.00. trom in $\$ 5.00$.

SNOWBERRY, RED, OR INDIAN CURRANT (Symphoricarpos Vulgaris). Specimen shrubs, \$1.50 to $\$ 2.00$.

SNOWHERRY. White (Symphoricarpos Racemosus). $3 \mathrm{ft}$. $\$ 1.00$ each. Specimen shrubs, \$1.50 to $\$ 2.50$.

\section{SPIRAEA.}

SPIRAEA, ANTHONY WATERER. Dwarf. 18 to 24 inches. 60c. Specimen shrubs, \$1.00 to \$2.00.

SPIRAEA, ARGENTEA (Golden Spirea). 2 to 4 ft., 80c. Specimen shrubs, \$1.50 to \$3.50.

SPIRAEA BILIARDII. 3 to 4 ft., 80e. Specimen Shrubs, $\$ 1.50$ to $\$ 3.00$.

SPIRAEA, BUMALDA. Dwarf. 18 to 24 inches, 60e. Specimen shrubs, \$1.00 to \$3.00.

SPIRAEA, REEVESI HLori PLENo. Double. $3 \mathrm{ft.}, 81.00$. Specimen shrubs, \$1..io to \$3.50.

SPIRA EA, VAN HOUTTI (Bridal Wreath). 2 to 3 ft.. 750 each; 2 to $4 \mathrm{ft.} \$ \$ 1.00$ each. Specimen shrubs, $\$ 1.50$ to $\$ 5.00$.

SUMAC. Cut-Leaved (Rhus Glabra Laciniata). 2 to $3 \mathrm{ft.}$ 1.25. Specimen shrubs, \$1.50 to $\$ 2.00$.

SUMAC Fragrant (Rocky Mountain). 2 to $3 \mathrm{ft.,} \mathrm{80c.}$

\section{SYRINGA.}

SYRINGA AVALANCHE (Philadelphus Hybrids). 3 to $\&$ it. 80c. Specimen shrubs, \$1.50 to $\$ 3.00$.

SYTINGA GRANDIFLoR (Philadelphus Grandiflorus). 3 to $4 \mathrm{ft}$., \$1.00. Specimen shrubs \$1.50 to \$3.06.

SYRINGA I,WMOINEI (Philadelphus Lemolnei), 2 to 3 ft. 5.5. Specimen shrubs, $\$ 1.00$ to $\$ 2.00$.

STRINGA, MOCK ORANGE (Philadelphus Coronarius). to $4 \mathrm{ft} ., 80 \mathrm{c}$. Specimen shrubs, $\$ 1.50$ to $\$ 5.00$.

SYRINGA, MONT GLANC (Philadelphus Mont Blanc). a to $4 \mathrm{ft}$., $75 \mathrm{c}$.

TAMARIX ODESSANA. 2 to 3 ft., 75e. Specimen shrubs, 1.50 to $\$ 2.50$.

TAMARIX HISPIDA AESTIVALIS. 2 to $3 \mathrm{ft}$, 7Je. Specio men shrubs, $\$ 1.50$ to $\$ 3.00$.

\section{WEIGELA.}

WEIGELA DESBOISI (Diervilla Hybrida). 2 to $3 \mathrm{ft}$, 60e Specimen shrubs, $\$ 1.00$ to $\$ 2.70$.

WEIGELA EVA RATHIE (Diervilla Hybrida). 2 to $3 \mathrm{ft}$. $\$ 1.00$. Specimen shrubs, $\$ 1.50$ to $\$ 3.00$.

Whigela RosEA (Diervilla Rosa). 3 to $4 \mathrm{ft.,} \mathrm{\$ 1.00.} \mathrm{Speci-}$ men shrubs, \$1.50 to \$3.110.

WEIGELA ROSEA NANA VARIEGATA. 3 to 4 1t, $\$ 1.00$. Specimen shrubs, \$1.50 to $\$ 3.00$. 


\section{THE BRYSON AYRES SEED CO,}
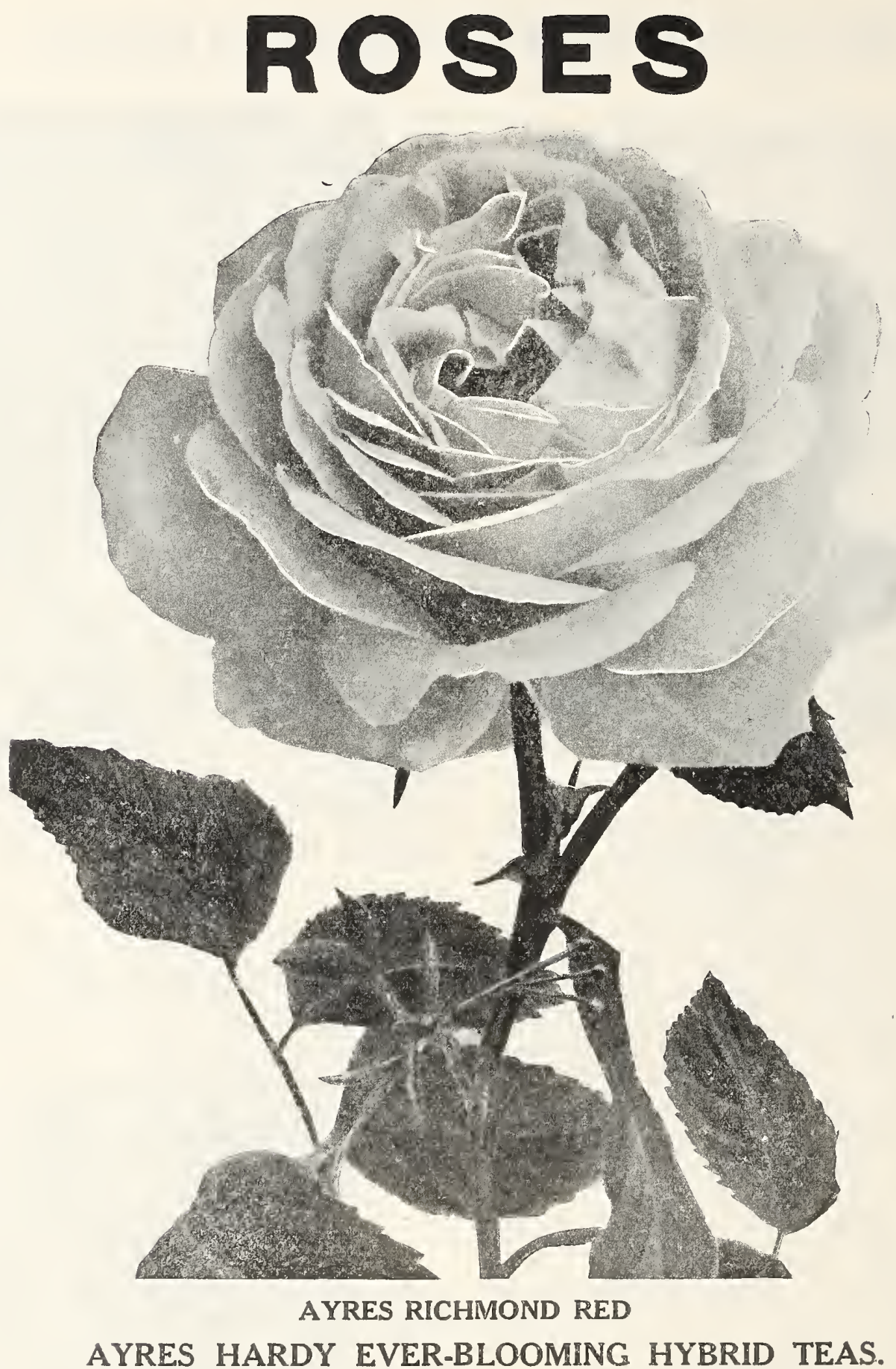

STRONG TWO-YEAR-OLD BUSHES, 75c EACH, \$7.50 DOZEN.

THREE-YEAR-OLD BUSHES, \$1.00 EACH, \$9.50 DOZEN.

Onr Rose Bnshes Bloom Profusely the First Season.

This is the class of roses for general planting everywhere. The great advantage claimed for them is that they combine the hardiness of the Hybrid Perpetual with the constant blooming qualities and delicious fragrance of the Tea Roses. These varieties we list include only the choicest, and your surprise will come from the quantities of beautiful blossoms they produce. Hardy in all localities and without protection, except in the Northern States, where a muich should be given them.
MURICAN BEAUTY. Very large and fragrant. Rather delicate; constitution requires especially well drained soll: rich crimson.

CAROLINE TESTOUT. Satiny pink, very large flowers. Excellent habit.

DUCHESS DE WELLINGTON. Intense saffron-Jellow, changing to a coppery yellow as the flowers develop. fragrant and free flowering.

GRUSS AN TEPLIPZ. Medium size, intense scarlet-crimson. strong grower, sweet scented and persistent bloomer. One of the best roses.

GENERA MCARTHUR. As an all-round garden rose, there is no variety of its color, a rich crimson, that will give better satisfaction. 


\section{ROSES-Cont.}

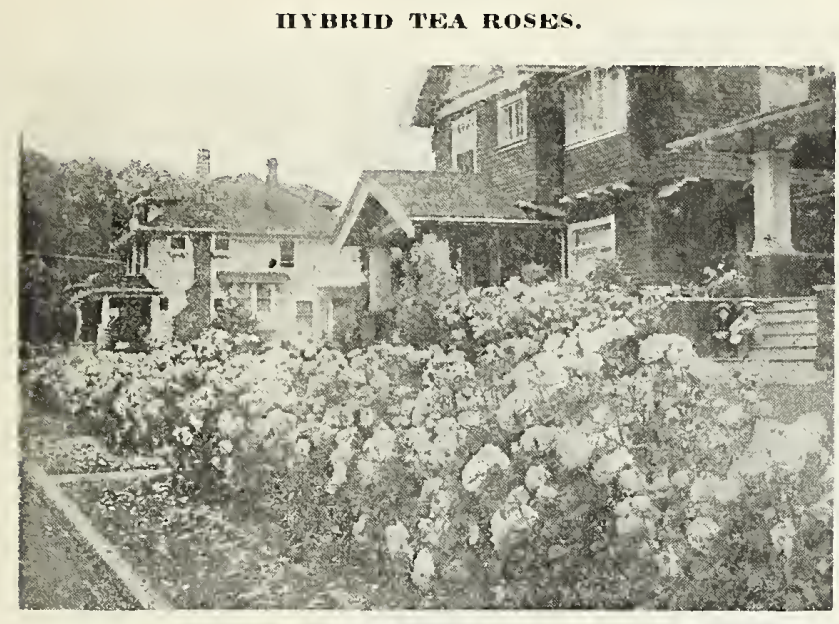

PROFUSELY BLOONIN CAROINNE TESTOUT ROSES

GEorgwous. Buds coral-red, shaded with yellow and rose; very beautiful.

HoOSIER BEA UTY. Rich dark red, fine budder, and very hardy and frairant

HADLEY. Darkest velvet color, fragrant and free flower-

JoNKELIR J. L. MOCK. Greatly improved La France, imperial pink; wonderful keeping qualities. The flowers are of large size, perfect form and highly perfumed.

KILLARNEY QUEEN. Deeper pink than Killarney, producing strong stems and long pointed buds; very hardy.

KILLARNEY WHITE. White, slightly tinted pink, long pointed buds, free bloomer, and no doubt one of the best white roses.

KILLARNEY BRILLINT. Rich shade of rosy carmine, almost double.

KAISERINE AUGUSTA VICTORIA. Soft pearly white. Very fragrant and productive.

LADY HILLIVGTON, Beautiful coppery shade of apricotyellow, pointed bud, very free flowering.

LADY PIERRE. Deep copper reddish-salmon, flushed fawn and copper, an ideal variety.

WA FRANCE. One of the best pink roses, very fragrant.

Los ANGELES, an improved Marshal Neil and more fragrant. Flame pink, gold at base of petal.

chrome-yellow at the base.

MY MARYLAND. Very free bloomer; flowers large and double; color bright salmon pink. "Should be in every collection.

MRs. B. IR. CANT, Bright rose pink, a strong healthy grower and productive.

MTS. AARON WARD. A remarkable floriferous variety of strons, vigorous, but compact, dwarf growth, pointed bud, full double flowers when open. Color a distinct Indian yellow, shaped lighter towards edges.

MRS. CHATLES RUSSELL. Long pointed buds, dark rosepink, one of the best keepers. Very fragrant and beau-

MADAM CHRISTY MILLER. Exquisite silvery,pink, one of the best varieties.

OPHELIA. Delicate shade of salmon-yellow, sliaded with rose, floriferous and beautiful.

RADIANCE, An ideal bedding variety of remarkable free flowering habit of a brilliant rose-pink.: One of the best garden roses; good lreeping qualities.

RED IRADIANCE. Rosy-crimson, vigorous and productive except color same habit as Radiance.

RICHMOND RED. True shade of red. Very hardy and prolific bloomer.

RHICA REID. Strong grower, and prolific bloomer, carmine rose color. Should be in every collection.

SUNBURST. A superb rose, of good, vigorous habit; buds long cup shaped. Color a rich yellow with orange-

WILLOWMERE. Coral-red color, suffused with carmine in bud state, and opens to a large full flower of a rich ghrimp-pink.

WM. R. SMITH. Creamy-white with rose shadings. Long pointed buds and an excellent bedder.
NOVELTY ROSES.

ColuMuIA. Large double flowers. Deer pink. Very pro-
fuse bloomer.

PREuIEk. Satin pink. Pointed buds. Very fragrant. Hardy grower.

BABY DoLL. Tiny buds. Rich apricot pink shading to yellow.

Moss Rosf: Deautiful shade of pink. Contrasting wonderfully with the mossy-like leaves. Very fragram.

SHAWTEIR. Wonderfully formed buds. Cerise. Coztinuous bloomers.

MILADY. One of the best deep red velvety red reses. Wery fragrant and profuse bloomer.

RLGOSA RosEs. Beautiful bushes and highly ormanental owing to the large masses of deep red berries.

Any of the above, two year old bushes $\$ 1.00$ enall. \$onst pex dozen.

\section{HARDY HYERID PERPETUAL ROSES.}

\section{HARDY HYBIRID PETPETUAX, ROSES.}

These roses are a most valuable class because of their large, sweet, brilliant colored flowers.

AMERICAN BFAUTY. Very large and fragrant, rich crimson color.

GEN. JA QUEMINOT. Too well known to require a lengthy description. It still holds first place among the dark red roses, and is one of the most satisfactory that grow.

FRAU KARI. DRUSCHKI. Color fine snow-white, free from any yellow or rose tints.

MADAME PLANTILR. The iron-clad white cemetery rose; bears hundrcds of beautiful, snowy-white fragrant blossoms.

PA UL. NEYRON. One of the finest hardy roses ever grown. It blooms unceasingly from June to November on uniformly long, stiff, thornless stems, with immense cupshaped flowers. Color, a bright rose pink.

ULRICH BRUNNFr. Flowers good size and fine form with shell-shaped petals. One of the most abundant bloomers, color, cherry red.

Any of the above strong two-year-old bushes at 800 each, \$\$.00 per dozen.

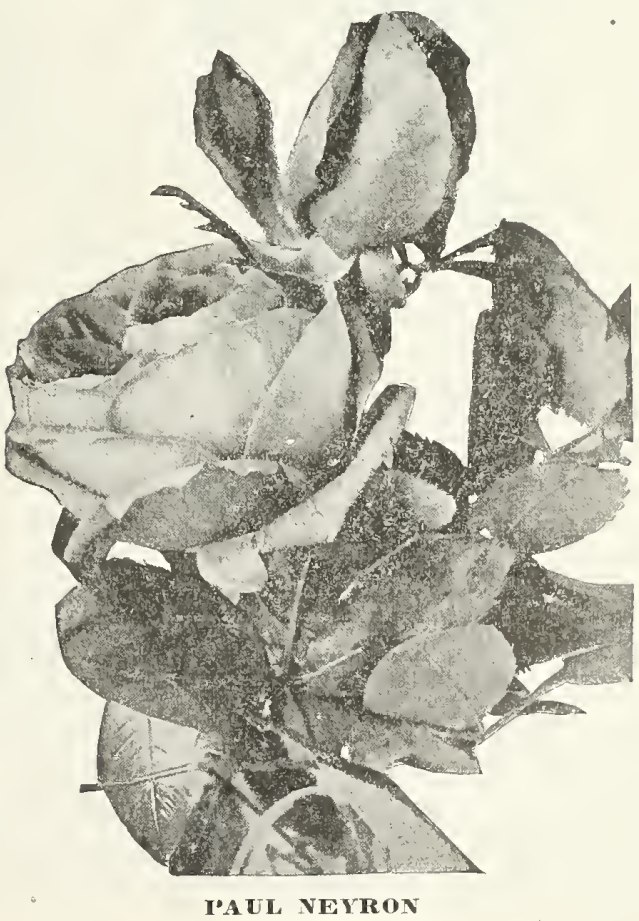


THE BRYSON AYRES SEED CO.

\section{ROSES-Cont.}

\section{HARDY CLIN BING ROSES.}

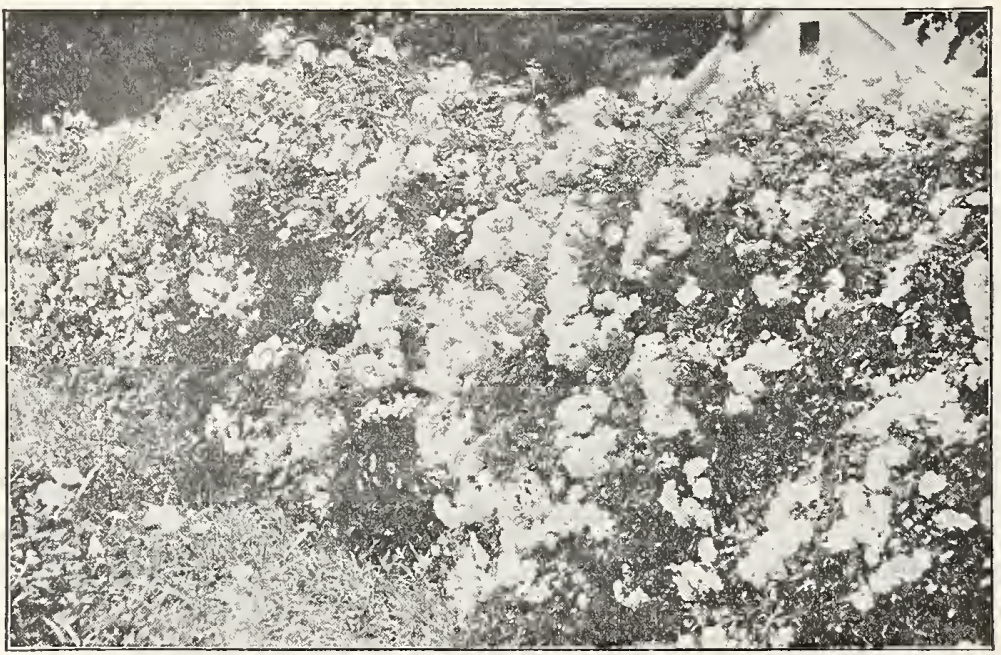

\section{THOUSAND BEAUTIES ROSE}

YOUR CHOICE, ANY VARIETY.

EXTRA STRONG FOUIR-YEAT-OID PLANTS, \$1.50 EACH; \$15.00 PETR DOZEN. Dozw.

Need No Protection Even in the Coldest Climate.

Very few vines give such an abundance of blossoms as the Climbing Roses. Again there is nothing in cultivation more beautiful and attractive. Surround your house and veranda cover your pergola, screens, and fences with these
famous climbing Roses. The stock we offer is choice and

WMERICAN PILLAR. Brilliant carmine rose, with a slight cream variegation and yellow stamens at center.

CLIMBING AMERICAN BFAUTY. This new climbing form of the famous rose so long the American favorite, is as lovely and fragrant as the bush form. The hardy climber blood with which it is crossed, gives healthy, perfect foliage and a strong climbing habit of growth; the abundant bloom being in prime before the June show of the bush type.

BALTIMRE BELL. Pale blush, variegated carmine-rose and white; very double; flowers in beautiful clusters, the whole plant appearing a perfect mass of bloom: one of Whole plant appearing

CRIMSON RAMBLER. The most popular Climbing Rose: CRIMSON RAMBLER. The most popular Climbing Ro

Dorothy PERKINS. A Climbing Rose. which is strong, vigorous growth and general habit, very closely approaches the popular Crimson Rambler: its flowers, which are borne in clusters, are of a beautiful shell pink, full, double, and of large size for a cluster rose, and deliciously scented.

WHITE DOROTHY. Brilliant green foliage of splendid texture and free from mildew, flowers are a glistening white and borne in great trusses.

DR. VAN FLEFT. Rich flesh pink, long pointed buds.

WILLIAM C. EGAN. Splendid pink flowers. A much-soughtfor rose: used for pillars and wherever an extremely hardy rose is wanted. Fine for hedges.

FXCELSA. A splendid Climbing Rose, remarkable in many ways but particularly in the brilliant fiery red or intense crimson-scarlet flowers which are very double and borno in trusses of thirty to forty.

EMPIESS OI CHINA. So ft dark red, changing to light pink, like an apple blossom. Splendid hardy climbing

FLOWER OF FAIRFIELD. The Fverblooming Crimson Rambler, brilliant crimson clusters of flowers.

LADY GAY. A seedling of the popular Crimson Rambler, which it closely resembles in habit and vigor of growth, but with flowers of a delicate cherry-pink, fading to a soft-tinted white.

MISS G. MESMAN (Climbing Baby Rambler). A grand acquisition to the list of Climbers. A strong grower and produces large, compact clusters of bright carmine flowers continuously from June until frost. An easy grower and very valuable for porches, arches, etc.

PHILADELIHA IRAMULE. Flowers produced in grand clusters: pure deep crimson: brighter than any of this clusters; pure deep crimson; brighter than any of this
class. holds color to the last; handsome foliage: blooms class. holds color to

PRAIIIIE QUEIEN An old standard variety, and one that wlll be popular. No collection of hardy Climbing Roses is complete without it. Bright, rosy red, large compact, and globular flowers.
PERSIAN YGLLOW. A favorite yellow climber

RUSSELL'S COTTAGE. Dark velvety crimson; very double and full; profuse bloomed.

SILVER MOON. HaIf double flowers. Very large. Pure white with yellow stamens.

THOUSA NO BEAUTIES. (Tausendschon): The most sensational climbing rose. Imagine a luxuriant rose llterally covered with thousands of large, double beautiful, bright blossoms and of the most delicate shade of pink. The color might be described as white, delicately flushed color might be described as white, delicately flushed pink which changes to rosy carmine. The name ls derived from the many colors and the great variation in single cluster is a bouquet in itself, flowering profusely single cluster is a bouquet in itself, flowering profusely from the beginning of June until the last of July. There is no other rose in cultivation to compare with lt. having but few thorns with magnificent foliage free from mildew and absolutely hardy in the open ground everywhere. This variety may also be grown in pots and forced into flower as is done with many of the tender varieties. In short it is the most remarkable rose of its kind in the world.

VEILCHENBLAU. (Blue Climbing Rose). It has always been most person's ideal to cultivate a blue rose, and we are now in a position to offer such a varlety. It has glossy, green foliag

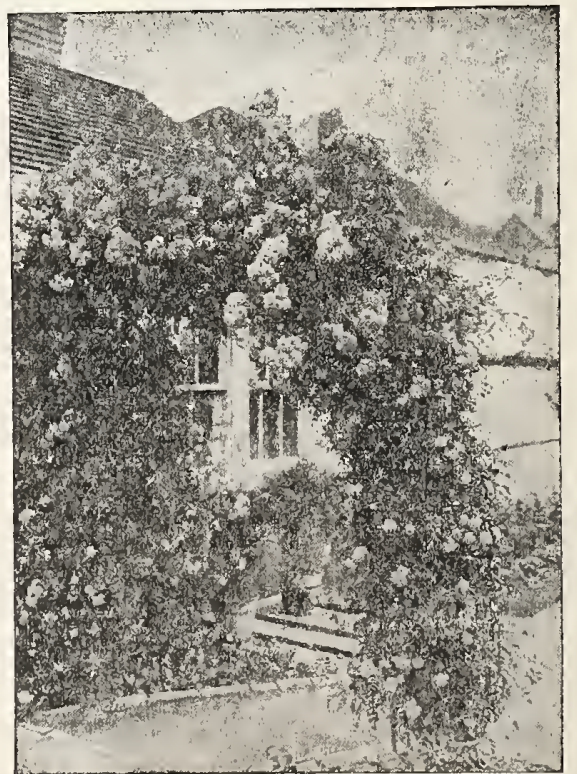

VEULCHEVUB A U BLUE CLIMHLR 


\section{HARDY PERENNIAL PLANTS}

The Garden of Hardy Fowers is of gorgeous boom from earliest spring until frost, glorified by its appropriate flowers from month to month, with new things each day to delight you. Year after year this goes on and the garden increases in beauty and loveliness, practically without any expense other than the first cost. Hardy flowers require less care and attention, are more free from insects and disease, yet producing abundance of beautiful blossoms. Among the Hardy Flowers are found all the old-time favorites and some of the noblest plants that have been dear to our grandmother's garden, famous in song and story-a fragrant memory of gay sweetness.

\section{ALL PERENNIALS UNLESS OTHERWISE NOTED, LARGE CLUMPS, 35c EACH, SIX OF THE SAME VARIETY \$1.75}

SPECIAL PEREN NIALS SUT'ALE FOR SILAMY PIACES. Achillea, Aegopodium. Anemones, Aquilerias, Aralia, santhemums, Shasta Daisies, Delphinium, Digitalis, Funkias, Hemerocallis. Hibiscus, Iris, al varietics, Lily of the Valley (Convallaria), Lychnis, Rudbeckias, Papaver (Poppies), Primulas, Physostegia Pentstemon, Pyrethrum, Sedum, Stokesia, spirea, Violets. All the above varieties will also thrive in sunny, open situations except Anemones, Campanulas, Digitalis Lily of the Valley, spirea and Violets.

SPECIAL, PEREVNIAIS SITARLE FOR HOT AND DRY PLACEs. Asters, Boltonia, Coreopsis, Cassia, Carnations, Shasta Daisies. Gaillaridia, Eulalias (Hardy Grasses), Hibiscus, Hollyhocks, Helianthus, Hardy Pinks, Liatris, Peonies, Phlox. Pyrethrum Rudbeckias. Sedum, Stokesia, Tritomas, and Yuccas. The above varietis will also thrive in partial shade. Other varieties not classified above may be used in general plantings.

ACHILEA. (Boule de Neige). Dwarf compact grower; fine Double white flowers in profusion all summer.

AGROSTEMMA. A clump of these flowers adds a dash of brilliant color to the border that is not equaled by any other flower.

A. coronaria (Rose Campion). Velvety crimson. June and July, $1 \frac{1 / 2}{2}$ to $2 \mathrm{ft}$.

ALYSSUM saxatile compactum. Masses of canary yellow. April and May. 9 inch.

ANCHUSA Dropmorei. A new perennial of great worth. It has gentian-blue flowers, in long sprays, like the Larkspur. June and July. Each, 5ie.

ANEMONE (Wildflower). Flowers resembling a dainty, Single rose.

AQUILEGIA (Columbine). Too well known to need much description. The hardy garden is not complete. without them. A vulgaris is perhaps the freest growing sort Long spurred hybrids; arious colors; April to June.

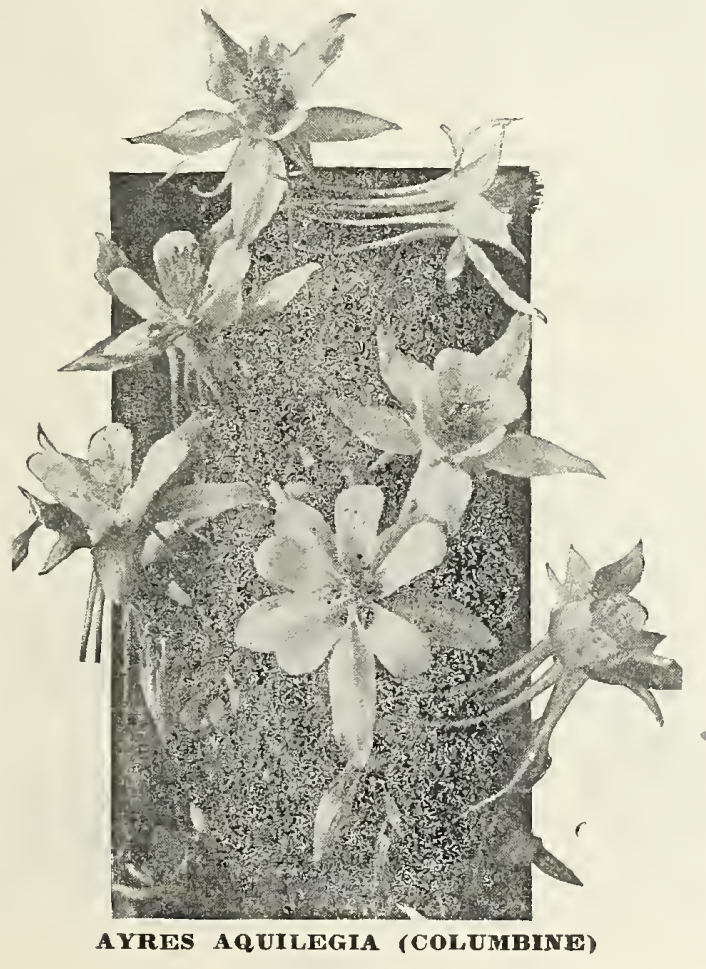

ASTER (Michaelmas Daisy). The Michaelmas Daisies are indespensable because they bloom when the frosts have killed most of the other flowers. They are an American product, of which we are proud. Do not mistake these for the China Asters, which are grown from sced and which are not hardy. They are strong growers and bear a profusion of bloom.

BoCConia (Plume Poppy). A unique plant, well adapted for shrubbery beds or to plant where a bold group is wanted.

BoLTONIA Starwort. Resembles the Asters. Excellent for massing. Pink and white.

CAMPANULA (Bell Flower). A hardy garden is incomplete without a collection of these charming perennials. The tall ones are excellent for cut-flowers.

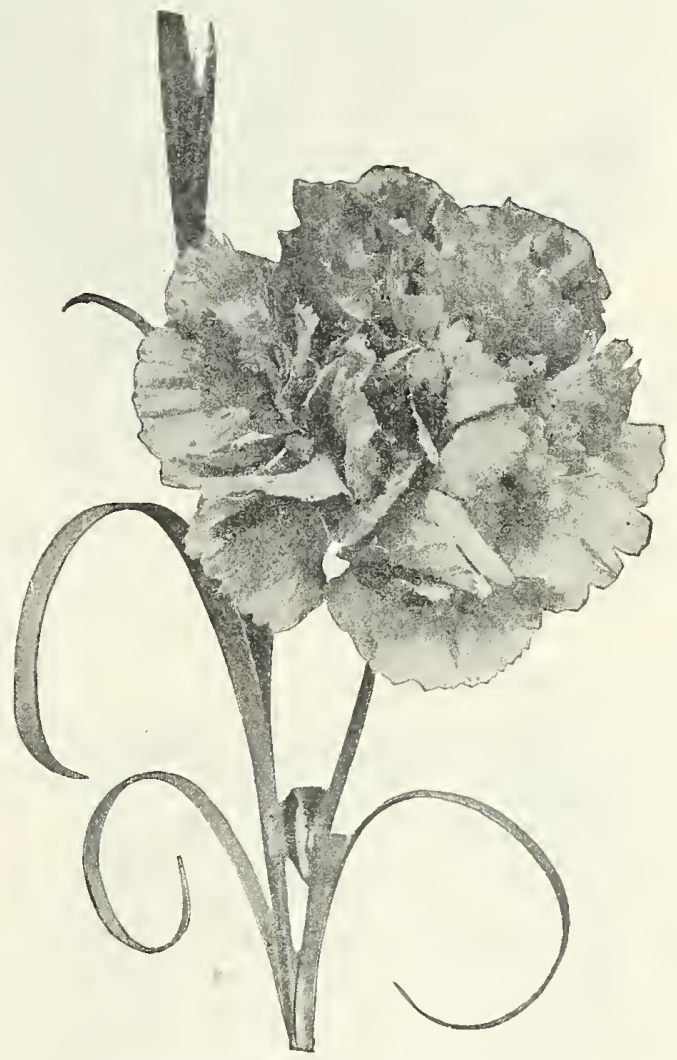

AYRES HARDY CARNATION. (FIRE FLAME RED)

CARNATION. Hardy. Valuable for cut flowers. Blossoms all summer. Our new fire flame red.

CENTAURIA Mont:" (Perennial Cornflower). A garden would be incomplte without a group of this attractive perennial. Good foliage; large flowers. Blue. June to September.

CLRASTIUM (Snow in Summer: Mouse Ear). Very striking silvery foliage, valuable in rockeries and borders.

CHELONE (Turtlehead). Valuable late flowering platts, doing best in partly shaded places and being most at home in swampy graund but will do well in the ordinary border. Rose-purple and white. 


\section{HARDY PERENNIAL PLANTS-Cont.}

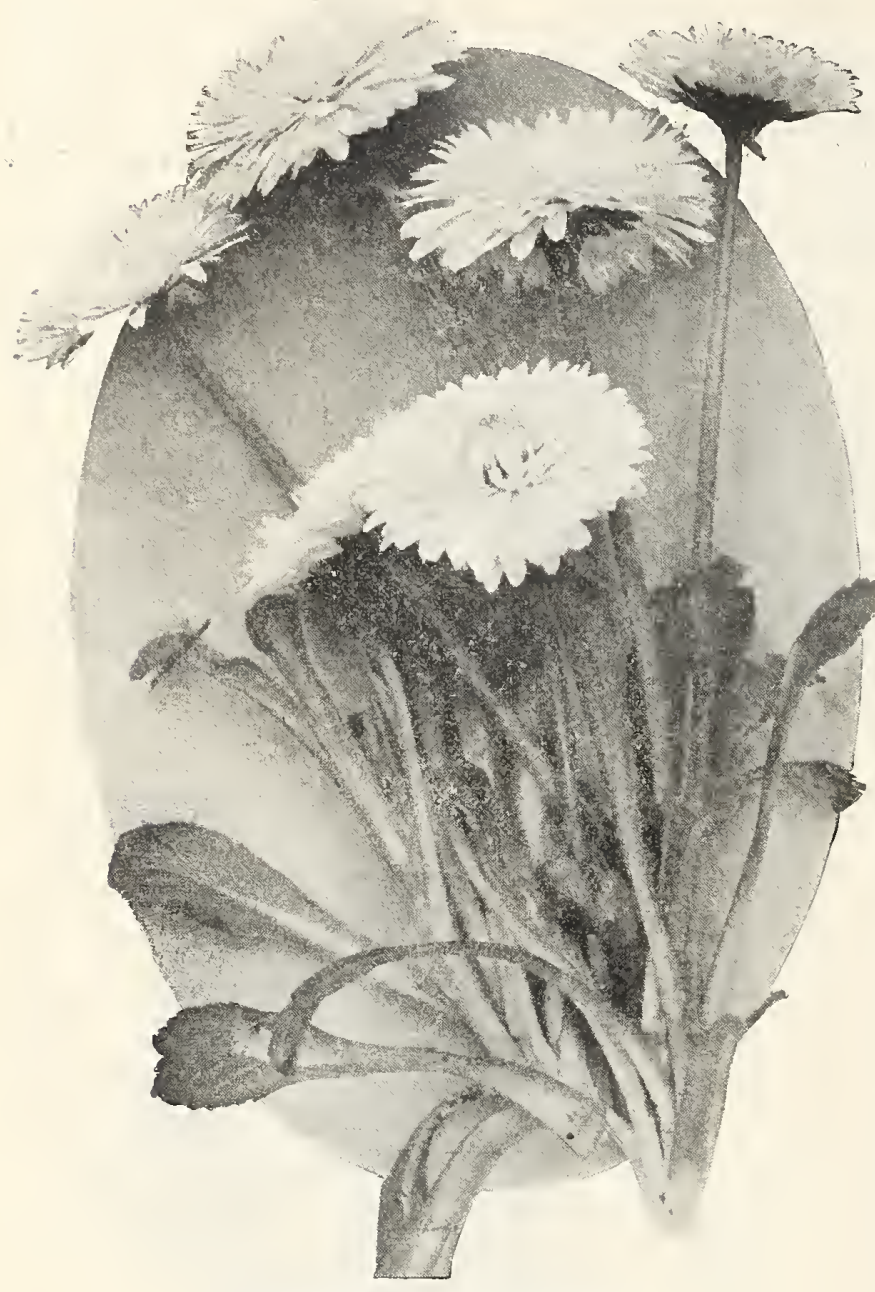

JAPANESE CHRYSANTHEMUMS

HARDY CHRYSANTHEMUNS-

our collection consisis of many varieties of every conceivable form and shade of color, and obtained at great expense from every possible source, so that we have every reason to believe that we have the inest collection in the reason to believe that we have the

Colors: Red, Yellow, White, Pink.

CHRYSANTHEMUM, "Shasta Daisy." A Burbank production of merit. Large, white. June to Septcmber.

CHRYSANTHEMUM, Japanese. Everblooming from June until frost. Golden yellow.

CONVALLARIA (Lily-of-the-Valley). Clumps, 50e each; Roots 75 e per dozen.

CORLOPSIS. The most common perennial and highly prized. The yellow, eosmos-like blossoms come in profusion all summer.

LANCEOLATA GRANDIFLORA. $1 \frac{1 / 2}{2}$ to $2 \mathrm{ft}$ Yellow. June to September.

ROSEA. Large growing, or rocikery, with rose red flowers

DIANTHUS. Highly prized old-fashioned garden plants that are indispensable in the border.

BARBATUS (Sweet Willam). 1 to $1 \frac{1}{2} \mathrm{ft}$. Various colors. May to July.

PLUMAIRIUS DIADIXIATIS (Scotch Pinks). 9 in. Semidouble, clove-fragrant flowers in all colors. May and June.

DICENTRA SPECTABLIS (Bleeding Heart). An attractive, early spring flower, that is most useful for cutting. 50c each: 6 for $\$ 2.7 \%$

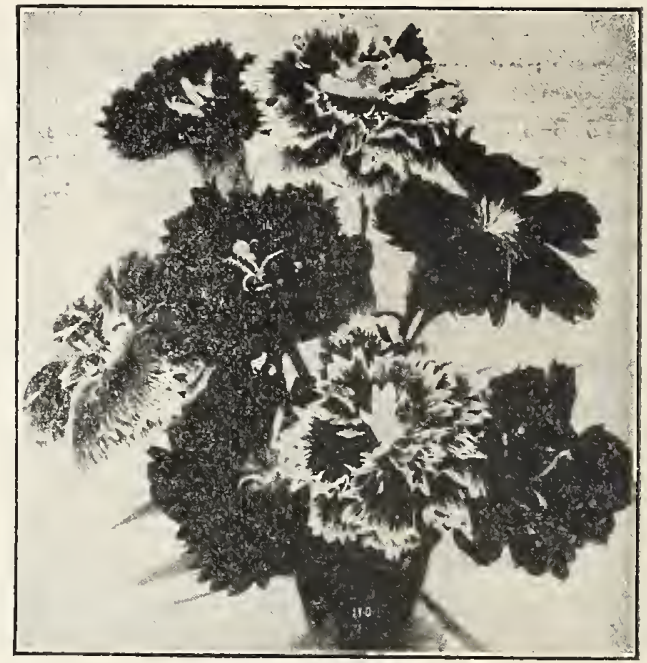

DIA NTHUS

DELIHINUM (Larkspur). One of the finest sights of modern gardens is a good collection of blooming Larkspurs. The tall, rich, showy flowers have been in hardy gardens for years. Good for cutting. We have some excellent strains.

CHINENSIS. 1 to $1 \frac{1}{2} \mathrm{ft}$. Flowers in varying shades of blue, violet and white. ForMosum. 3 it. Indigo. A favorite shade. June to August.

BELLADONNA. The freest and most continuous bloomer of all; clear turquoise-blue.

GAILlARDIA (Blanket Flower). No plant in the hardy flower-garden gives more satisfaction than the Grillardia. It flowers in great profusion nearly all summer long. The lcng, dry spells affect it very little. Cut-and-Comeagain is a good description of this plant.

GYPSOPHII.A (Baby's Breath). Loose, feathery white flowers highly suitable for bouquet purposes. Fine for mixing with sweet peas.

GOLDEN GLow. Very double yellow. Flowers in Aug'st and September.

HELENTUM SNEEZEWORT. Where a large mass of bloom is required, the Heleniums are excellent subjects.

HELIANTHUS (Perennial Sunflower). The perennial. Sunflowers, without exception, are good for cut-flowers. They have not the large coarse heads of the common, annual Sunflower. All the double Sunflowers resemble yellow dahlias.

HFutroc a The Hemerocallis, or bronze and yellow Day Lilies, are among the most popular of and yellow Day Liles, are among the most popular or hardy plants, and if all the kinds are planted, will Eive a succession of bloom all summer long. The long stems elevate the showy flowers well above the foliage. All are robust growers and satisfactory in every way. Do not confuse with Funkia.

Fi. A A (Lemon Day Lily). $11 / 2$ to $2 \mathrm{ft}$. A lovely flower, nicely formed, fragrant. Yellow. June.

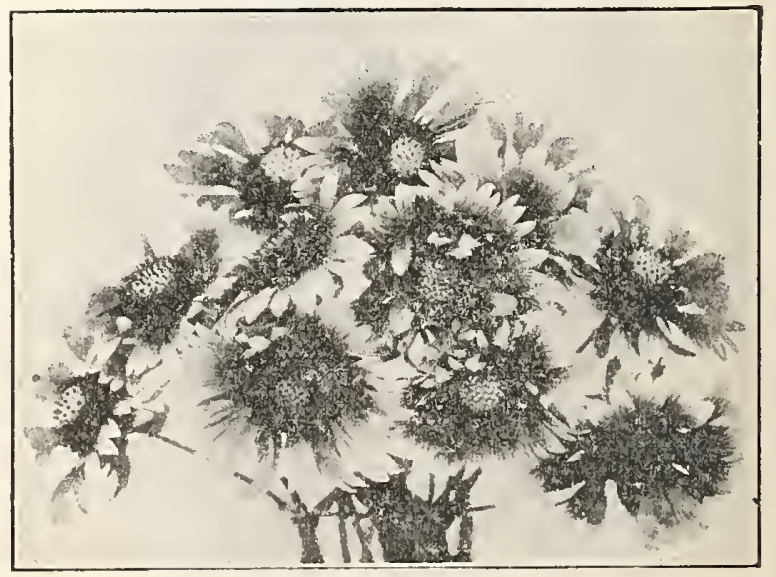

GAILLARDIAS 


\section{HARDY PERENNIAL PLANTS-Cont.}

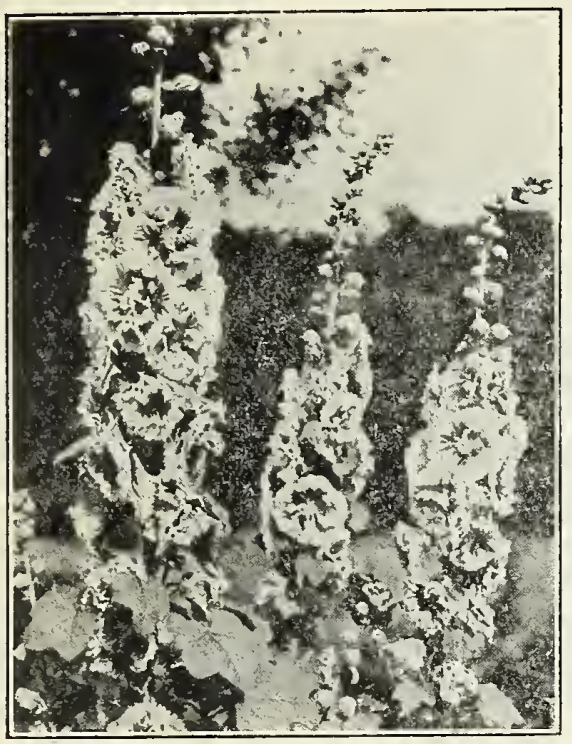

ALLEGHENY HOLLYHOCI

AURANTIACA. Large orange yellow flowers. 2 to $3 \mathrm{ft}$ June and July.

HUUCHEA (Alum Root). Dainty little plants with the loveliest coral-like flowers imaginable, borne in delicate sprays. - Very free flowering. Use in the ruck-garden or semi-shaded spots anywhere. Nice foliage.

SANGUINEA MAXIMA. 1 to $2 \mathrm{ft}$. Bright coral red, large flowers. June and July.

HIRISCUS. (Mallow). Hibiscus is best adapted ror planting in a damp place, along streams, or in positions where a large, showy plant is required.

HIBISCUS RED. Bright red; very showy.

HIBISCUS PINIK. Soft shades of pink.

HIBISCUS WHITE. White and very pale-tinted kinds. Any of the above Marvels, 2-year roots, z5e each.

HOLLYHOCK. (Allegheny Hollyhock). The stately Hollyhock is increasing in popularity. The Allegheny Strain has prettily fringed eages. It was in great demand when introduced a few years ago, and the supply was quick'y exhausted; but we now have a good supply. All kinds flower from June to August and grow 6 to $8 \mathrm{ft}$.

DOUBLE. Rosette flowers in white, pink, red, maroon and yellow.

IBERIS SEMPERVIRENS SUPERAA (Hardy Candytuft). 6 to 9 in. An improved form. White. April and May. One of the best for bordering or rock-garden use

LAVA NDULA VERA (Lavender). The Lavender bears those familiar fragrant spikes of flowers so useful for the linen closet. Gray, evergreen foliage.

All Perennials, unless otherwise noted 25e each. Six of the same variety, \$1.50.

\section{LILY.}

Swaying their graceful heads in midsummer, filling the air with fragrance and producing wonderful effects, the charming American and Japanese Lilies fill a distinct place oharming American and Japane

We predict they will be far more popular in a few years, when they become better known, although thousands are now planted every year.

In solid beds the effect is gorgeous. They occupy small space and thrive in a semi-shaded situation. Among shrubs ar rhododendrons they raise their heads above the other plants and flower in all their glory.

AURATUM (rold-banded Lily of Japan). Pure white with gold band. Huge flowers. 40 ex exh.

CANDIDUM (Madonna Lily). The fine old Annunciation Lily with tall stems of flagrant, pure white. Tall. Very hardy and lasting, 40e each.

SPECIOSUM MAGNIFICUM. Btight, rich red; 40e each.

SPECIOSUM ALißM (White Japanese Lily). All the Speciosums are lovely: flowers on branching stems, gracefully suspended. 40. each.
IRIS.

FLAG OR FLEUR DE LIS.

It is extremely beautiful, and can be grown with great ease No garden is complete-without some, and to acquire the Iris habit is to assume a hobby that can be ridden to the heart's content.

There ale several main groups as well as additional species, each having distinctive merits all combining to make a superb family of hardy plants, unsurpassed by any

Prices of all varieties, 3re each; per doz., \$3.50. Smaller divisions, 25e each: $\$ 2.50$ per doz.

AUREA. Rich chrome-yellow. A very fine Iris.

ADMIRAL TOGO. White, faintly tinged lavender. Extra fine.

DARIUS. Rich canary yellow; falls lilac nargined white. ECLIPSE. Velvety claret red, shaded violet; throat markings gold.

FLoRENTINE: ALAA. Waxy white, tinted lilac. Early bloomer.

GRACCHUS. Crimson, reticulated white; fine early,

L'INNOCENCE. Deep lavender standards; white falls.

MAORI KIVG. Golden yellow, margined velvety maroor gold.

MME. CHERAU. Pure white; irregular border clear blue Tall.

PENclore. White, delicately veined reddish purple.

KOCHII. Rich claret purple; handsome.

REMBRANDT. Light lavender; falls deeper.

TINNAF. Deepageratum blue.

TRAUTLIFB. The nearest pink Iris, shaded lighter at base.

IRIS LAEVIGATA KA GMPFERI-Japanese Iris.

Flower in July after the Fleur-de-Lis have long finished their bloom. They prefer moist situations, where they will develop flowers of great size and wonderful colors.

\section{SIBERIAN IRIS}

SIBIRICA (Siberian Iris). Just the Iris for moist situations, as are the varieties below. Foliage narrow; flowtions, as are the varieties below. SIBRICA ORIENTALS. Rich reddish purple blossoms. A splendid Iris

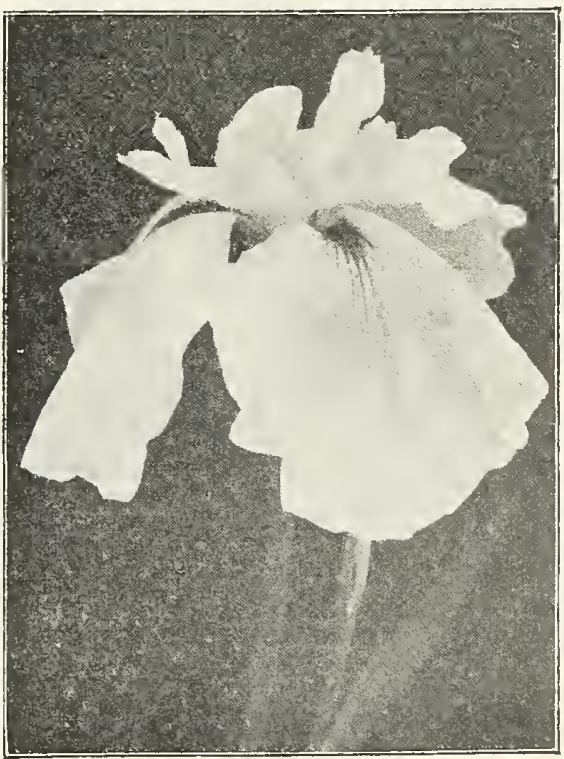

GERMAN IRIS-LA INNOCENCE. 


\section{HARDY PERENNIAL PLANTS-Cont. PAEONIES}

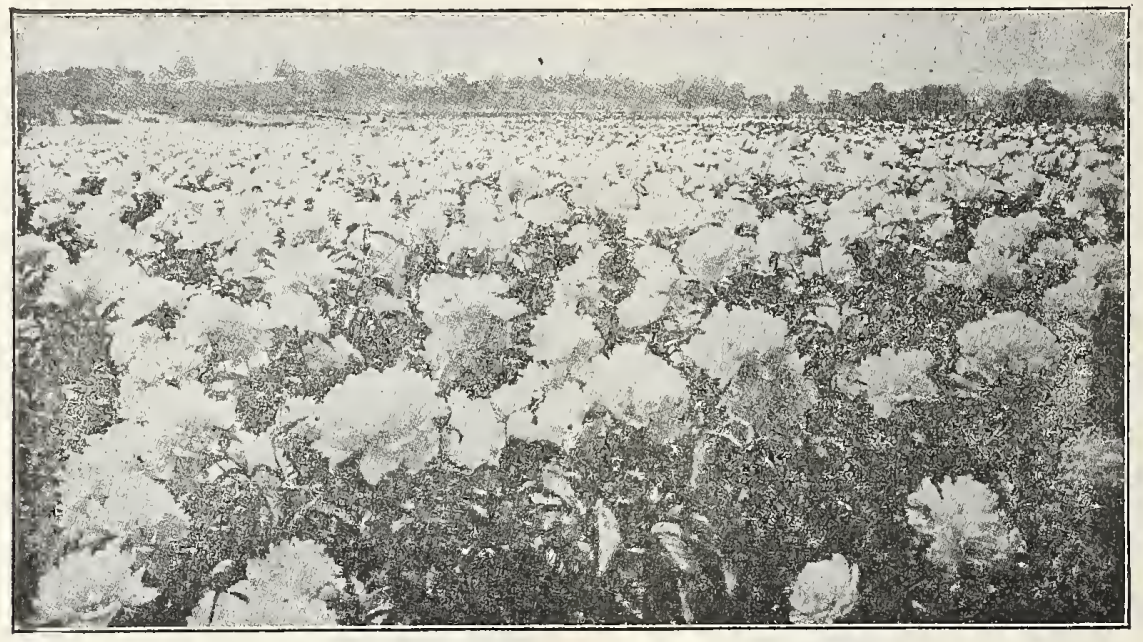

ACRES OF PALONIES AT OUR NURSEREIES

BRYSON A YRES PAEONIES-THE QUEEN OF FIOWERS.

Everyone loves the Paeony. We can all recall the enthusiasm of our grandmothers over the garden Paeony. You can imagine the raptures if those old people were blought in contact with the splendid varieties of today.

Paeonies require less care after planted than any other llower, but they will respond abundantly to good care and attention.

They should be planted $31 / 2$ to 4 feet apart in gosd garden soil, and be set so as the eyes or crovvns will be from $21 / 2$ to 3 inches below the surface. Mulch them in the fall.

We advise August, September and October as the best time to plant them, but they can also be planted in the early spring. We sell Paeonies only of our own growing. and not until they are tried out in our nursery, at least three years and make no pretense to compete with those who have no stock of their own, but only buy and sell them again, with no assurance of their being true to name or quality.

ALRERT CROUSSE (Crousse 1893). Immense convex, roseshaped flowers, fresh salmon-pink, one of the most striking, 1 yr., 50e; $2-y \times ., 75 e$ each.

ALEXANDRE DUMAS (Guerin 1862). Lively brilliant pink, interspersed with white. salmon and chamois. Very pretty and one of the earliest of the Chinensis sorts to bloom. 1-Yr., 50c each; 2-Y1*, 750 cach.

ASA GRAY. Large semi-rose type. Pale lilac, sprinkled with minute dots of deeper lilac. Of medium height and habit. A very distinct variety. Late. 1-yr., $\$ 1.00$ cach; 2-yr., \$1.50 each.

BARON J. ROTHSCHIED (Guerin 1850). Outside petals rose, center salmon, fragrant, 1-yr., 50e each; 2-vr., 75e each; $\$ 4.00$ per dozen.

BERNARD DE PALSSY (Crousse 1879). Fleshy white wilh glossy reflex. 1-yr., s0e each; 2-yr., The each.

EDOUARD ANORW (Mechin 1874). Targe globular bloom; deep crimson-red shaded black, with metallic luster on the reflex of the petals, a magnificent striking color;

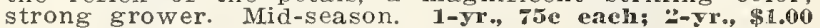
each.

EDULIS SUPERIBA (Lemon 1824). Pink, slightly violanceous, intermixed with narrow whitish petals. Early. 1-yr., 50c ench; 2-yr., 75e each.

FEEIX CROUSSE (Crousse 1881). Large full ball-shaped bloom; brilliant red with ruby-flamed center; exceptionally bright, effective and desirable, Late mid-season. $1-y \mathbf{r}, \$ 1.00$ each; $:-y 1 ., \$ 1.50$.

FWSTIVA MAXIMA (Miellez 1851). Enormous, very full shell-formed bloom; color snow-white shading to delicate creamy white at base of petals, with an occasional clear purple spot on edges of center petals; very fragrarit. Early. 1-yr., 75c cach; 2-yr., \$1.00 cach.
FLORAL TREASURE. This variety has few, if any, superiors as a cut flower. It is an excellent bloomer, bearing fine, large blossoms on strong, stiff stems. Color of flowers a bright light pink. 1-yr., \$1.00 each; 2-yre, $\$ 1.50$ each.

MEME. CROUSSE (Calot 1S66). Very large, full, well-mado flower; color snow-white, center petals edged with bright carmine. One of the firiest. Mid-season. 1-yr., 75c: $2-\mathbf{y r}$. $\$ 1.00$ each.

MATI LEVOINE (Lemoine 1869). Enormous sulphur white bloom, shaded with pink and chamois: strong stems of medium height. Wagnificent variety. Very late bloome of medium height. Magnificent variet

M. JULAS ELUT: (Crousse 1888). Immense globular, very full, imbricated flower of very strong long stems; petalage broad and overlapping, forming the most perfect Peony in existence; color, the finest glossy flesh-pink shading to deeper rose at the base, the entire bloom covered with a silvery reflex. Mid-season. I-עr., 75c eachi; 2-y1., 51.00 each.

RUBRA SUPERBA (Richardson 1871). Very large and full. dark velvety crimson. the best late dark crimson. 1-Jro, $\$ 1.00 ; 2-y$ r., $\$ 1.50$ each.

TRIUMPH DU NORD. (Deep Pink.) A grand sort; extremely early. Bears its deep pink glorious blossoms in wonderful profusion. It is a striking variety. 1-yr., 75e; 2-yr., \$1.00 each.

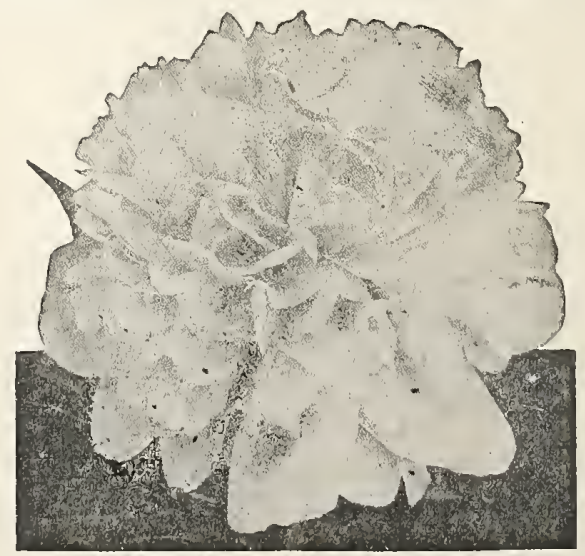

AMERICAN REAUTY PEONY

\section{LARGE SPECIMEN PAEONY CLUMPS, EIGHT YEARS OLD, CAREFULLY BALLED AND BUR- LAPED, $\$ 4.00$ TO $\$ 7.00$ EACH.}




\section{HARDY PERENNIAL PLANTS-Cont. PHLOX \\ JULES SANDLIRS (Dwarf). Very large flowerlag. Pazo
pink. Extra. fine.}

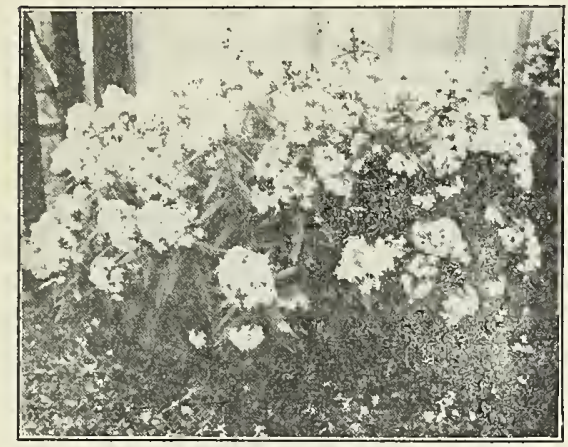

AYRES HARDY PHLOX

HARDY GAIEDEN PHIOX.

For all-round reliability the Phlox is not outdone by any other hardy perennial.

There are varieties of the most vivid crimson, the clearest and softest shades of pink, clear mauves and purples, and snowy white. The colors are apt to deteriorate as the plants become old, but new plants should be set in to take the place of the old.

Price of Phlox, except where otherwise noted, are asc each.

ANNIE COOK. Flesh pink

ASTARA. Violet-purple, pure white center, petals undulated.

8. CoMPTE (Medium). Brilliant French-purple. with crimson carmine shadings. 35e cach.

COQUELICOT. Fine pure scarlet. (Dwarf)

ECLAIREUR. Tall brilliant, rosy magenta, with lighter eenter; large flower.

ELIZA BETH CAMPBWL, (Medium). Very light salmonpink, with lighter shadings and dark crimson eye. The most popular Phlox grown today. 35e cach.

EUROPA (Medium). A white variety, with very decided crimson-carmine eye. sic cach.

FERNAND CORTEZ (Tali). Deep crimson with much darker center, giving bronze effect. 35c each.

GENERAL VON HEUTSZ. Brilliant salmon. 35e each.

INDEPENDENCE: (Medium). Large, pure white.

JEANNE DE ARC (Tall). A good standard late white. $35 \mathrm{c}$ each. I. VAGUE. Clear pink, vermilion center. (Dwarf, MME. MUURT. Flame color, carmine center. (Dwar.) MMIS. PAUL DUTRIS (Dwarf). A delicate, lilac-rose, re minding one of some of the beautiful soft-pink Orchids 35 enelu.

MTS. WNEINS (Tall). The best tall early white for massing. STe each.

PANTINON. Brilliant carmine-rose. (Medium,)

PINIK BEAUTY (Tall). An enormous spike of beautiful pale pink flowers; very fine. 35e cach.

IRHEINUANDER. (Dwarf). A most beautiful salmon-pink, with flowers and trusses of immense size; 3re each.

RECHARD WALACE. (Dwarf). White, violet-carmine center.

RYNSTROM. (Tall). A great improvement on the popular variety, Pantheon; of the same carmine-rose color as the Paul Neyron rose; 3üc each.

P2. STLUTHETS. (Tall). Salmon-pink with crimson center. 35e cach.

THOR. (Dwarf). A most beautiful and lively shade of deep salmon-pink, suffused and overlaid with a scarlet glow; 3éc each.

'IOLSTOI. (Tall). Coppery amaranth, carmine red reflex, and blood-red center; 35e each.

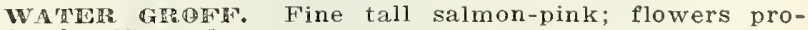
fusely; 35e esach.

W. C. FGA (Medium). One of the finest Phloxes yet introduced, and while the individual flowers according to the color chart are of a delicate lilac color, illuminated by a large bright solferino eye, the color effect as a whole, is a delicate, pleasing shade of soft pink; 35c each. WM. RAMGI. (Medium). A fine deep crimson.

\section{DHIOX FOR FOCRERIES AND CARPETHNG}

PHLOX SUBULA'. For rockeries and carpeting. An early spring-flowering type, which, during the flowering season is a mass of bloom. An excellent plant for the rockery and border, and invaluable for carpeting the ground or covering graves.

rogEA. Pink. Clump, 35e each.

LAVRNDER. 3Fe each.

\section{PRICE OF PHLOX, EXCEPT WHERE OTHERWISE NOTED, ARE 25c EACH. EXTRA SPECIMEN FIVE-YEAR-OLD CLUMPS, \$1.00.}

PAPAVER (Poppy). The Oriental Poppy with its rich crimson flowers is one of the most grorgeous of our hardy perennials.

ORIENTALE. (Oriental Poppy). Huge scarlet flowers. June 50c each. 5 year old clumps, \$1.50 each.

ORIENTALE, Livermore. Blood red. June. 35e cach. Large Clumps, \$1.25.

ORTENTALE, Royal Scarlet. Intense scarlet. June. 35c each. Large Clumps, $\$ 1.25$.

PHYSOSTEGLA. Obedient Plant. The long-flowering spikes of this fine plant are fine for cutting purposes. VIRGINICA. $2 \frac{1}{2}$ to $31 / 2 \mathrm{ft}$. Bright pink and white. August.
asc each.

MARIESI. $11 / 2$ ft. Dwaif. Plue and white. June to October. 35e each.

Polygonum. Compactum. Grows 15 inches high; during August and September the entire plant appears as a foamy mass of white flowers; 35e each.

PRIMULA. Primrose. The English Primrose with its flowors of every color is a most pleasing border plant. A northern exposure with shade is best. 35c each.

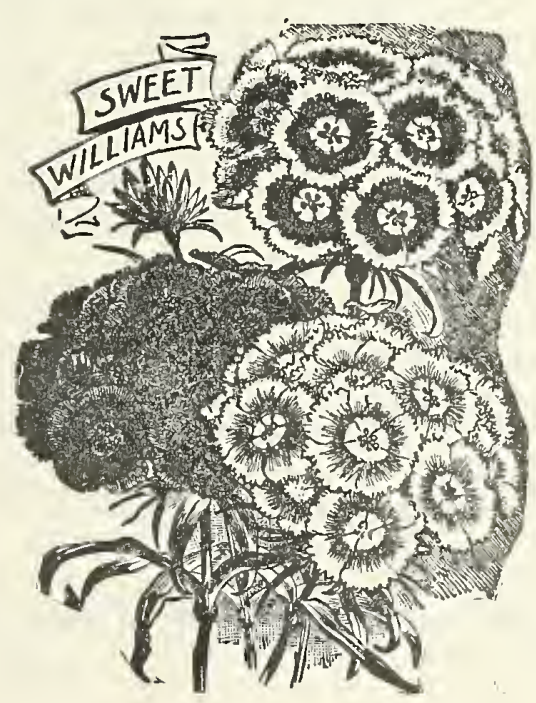




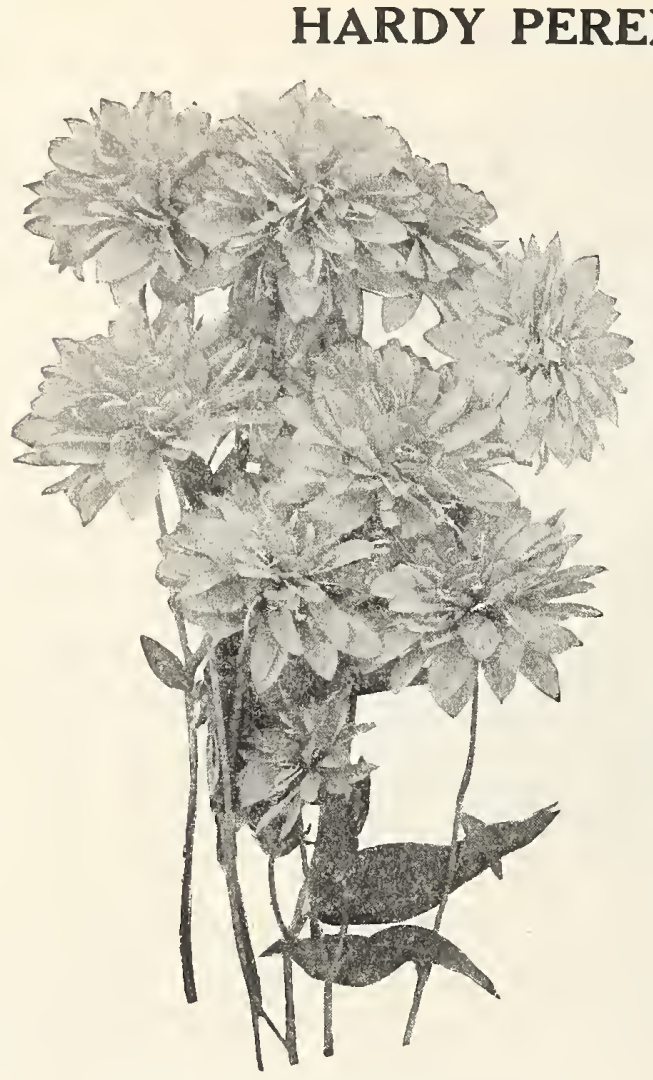

RUUHECKIA OR GOLDEN FLOW

POLYANTHA. Cowslip. 6 inches. Clusters of flowers on each stem. Various colors. April to June, 35e each.

PYRETHRUM. Mixed. Attractive, useful hardy plants for furnishing blossoms for bouquets. They thrive in almost any soil, and improve with age.

PYReThrum Roseum. 1 to $1 \frac{1}{2} \mathrm{ft}$. Very pretty daisy-like flowers. Low foliage. Flowers on good stems. Single In shades from rod and pink. June. 35e each. Extra clumps, 50e ench.

HUDBECKI. Golden Glow. Very free flowering. Showy blossoms, useful for cutting purposes. aje cach.

SALVIA. Azurea Granditlora. Growing 2 to $2 \frac{1}{2} \mathrm{ft}$, producing during August and September, sky-blue flowers in profusion; 35e each.

SWEET WILlIAM. Too well known for description. Wi offer these for the first time in separate colors. Salmon red, pink, white and variegated.

TRITOMA. Red-hot Poker. The most curiously formed head of flowers in cultivation. Flamboyant is a very good description of the flowerheads. July to October: s0c each; \$5.00 der Io\%.

VGRONICA. Speedwell. Veronicas are grand subjects for the hardy garden, also rock garden. The long narrow spikes are attractive.

LONGFOLIA SURSESSIIIS HENDEHSONII. $1 \frac{1}{2}$ to $2 \mathrm{ft}$. A grand hardy perennial for everybody. Big blue spikes. August. 35e each.

INCANA. Bright silvery foliage, with spikes of amethystblue flowers. July and Alugust. One foot high. 35e each.

VINCA MINoIk. Periwinkle or Myrtle. One of the best evergreen ground covers. Blue flowers. April and May trailing. 35e each.

\section{HARDY GRASSES.}

The common striped grass, Eulalia variegata, is very attractive and another form in which the bars run crosswise, is Eulalia zebrina. Very effective results can be secured from the hardy grasses, coming as they do in all forms and kinds of foliage.

Interspersed in the shrubbery or perennial border, they are at home. They are fine a 5 formal beds, being unquestionably the plants that give the best all-round effect, spring, summer and fall.

Prices on all Grasses: Root-clumps, 6 in. diameter, 50c each; extra heavy clumps, 75e each.

EULALIA. False Pampas. The real Pampas Grass is not hardy in the North, but the Eulalias are good substitutes and hardy.

E. JAPONICA. 6 to 8 ft. Rich, green foliage which waves with the slightest breeze.

E. JAPONICA GRACILIIMA UNIVITPATA. 5 to $7 \mathrm{ft}$ Narrow leaved variety of the onc above, very graceful and pleasing.

d. JAPONICA VARIEGATA. 4 to $5 \mathrm{ft}$. Striped with white variegation forming an attractive plant when grouped with the green.

E. JAPONICA ZWBIR A. 5 to $7 \mathrm{ft}$ Barred with bronzeyellow, and very popular, due to the bizarre effect proauced.

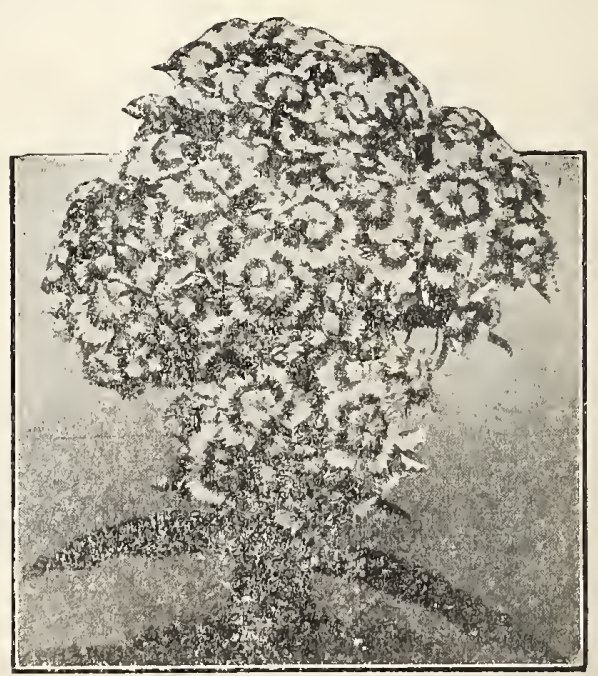

SIVEET WILIIAM-SALMON IPINK 


\section{CLIMBING VINES AND CREEPERS}

Climbing Vines are just as necessary in the beautifying frounds as shrubs, trees or grass: they have their important part in the planting of every place.

cround new buildings, they give shade quickly and are rery rouline and cheerful. rery cooling and cheerful. For verandas or trellises, ther is nothing that adds more beauty than a proper selection of .vines and, by covering summer-houses, or trunks of

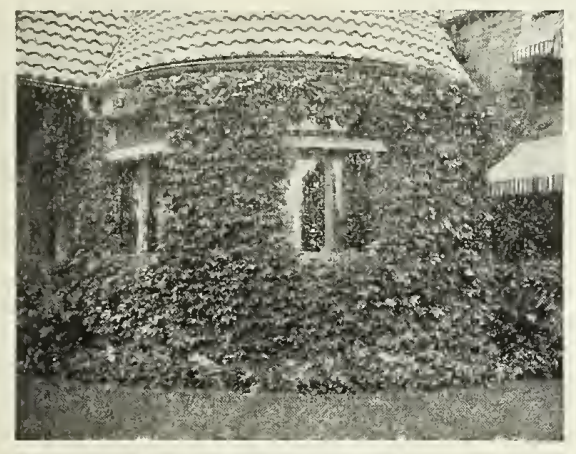

BOSTON IVY

AMPEI,OPSIS FNGELMANNI (Engelmann's Ivy). This is perfectly hardy in Missouri and will cling to brick, stone or stucco.

AMPELOPSIS QUMQUEFOLIA (Virginia Creeper)

AMPEI.OPSIS VEITCIII (Boston Ivy). Very fine. Will cling to brick, stone or stucco

BIBNONLA RADICANS (Scarlet Trumpet Vine)

GELASTRUS SOANDENS (Bittersweet)

\section{CLEMATIS}

GLFMATIs, CoCCINla (Scarlet Clematis).

GLEMLTIS DUCHASS OF EDINHURGH.

CLEMATIS, HENRY. Single white

CLEMATIS, JaCímaniI. Large single purple.

GLEMATIS MADAME WDOUARD ANDIRE. Large single red. Clanatis paniculata. Pure white in clusters. 2 yrs. old, 75e each.

Note-We guarantee Clementis to reach nur cusioners in good condition but we cannot agree to replace if they fail to grow.

ALL FLOWERING VINES LISTED ARE OVER

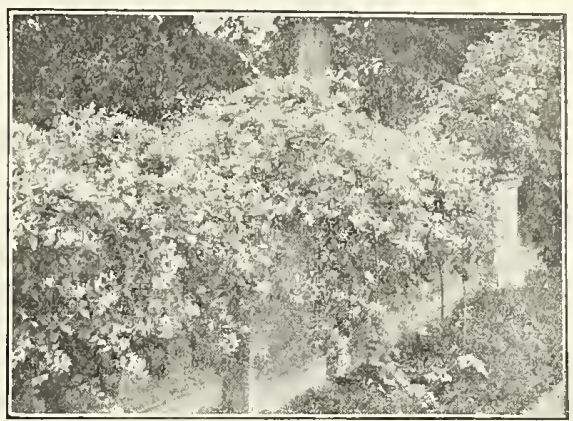

SWEET HONEYSUCKLW

OU'TCHMAN'S PII'E (Aristolochía Sipho).

HONEYSUCKLE. Hall's Japan (Lonicera Halliana), 2 yrs. old. Fise eath.

HONEYSUCIr. Scarlet Triumpet (Lonicera sempervirens) 2 yrs. old. $75 \mathrm{c}$ eilch.

VITIS, or HARDY WVIID GRAPE.

VTTIS, HETA (Grape).

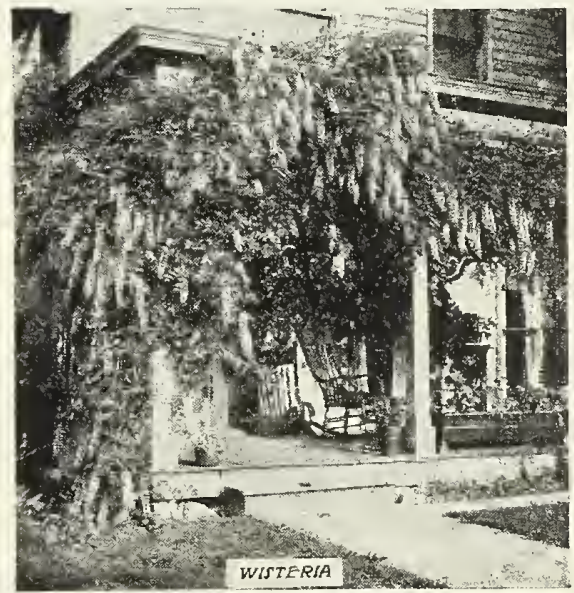

WIStaria CHINHNsis (Chinese Purple Wistaria) WISTARIA CHINENIS ILBA (Chinese White Wistaria)

\section{NOTED, YOUR CHOICE, EACH, $\$ 1.00$. IVIES, 50c EACH.}

\section{SIX LEADING PERENNIALS}

We list herewith six Hardy Perennials in extra specimen size clumps that will bloom profusely this coming season. In case you want immediate effect in your hardy garden, be sure and try a few.

Oriental Poppy-Gorgeous orange red; blossoms as large as a saucer. Extra specimen size clumps, each $\$ 1.25$.

Gypsophila Paniculata-Beautiful pure white. Lasts nearly all summer and is wonderful dried for winter boquets. Extra specimen size, each 50c.

Everblooming Japanese Chrysanthemum-This wonderful flower should be in every home. It is truly a wonder-begins to bloom in June and continues throughcut the summer and fall. Color, beautiful golden yellow. Needs no protection during the winter. Extra scecimen size clumps, each $50 \mathrm{c}$

Carnation Fire Flame-This beautiful Red Carnation is in bloom continually from May until late fall. Extra specimen size clumps, each $75 \mathrm{c}$. 


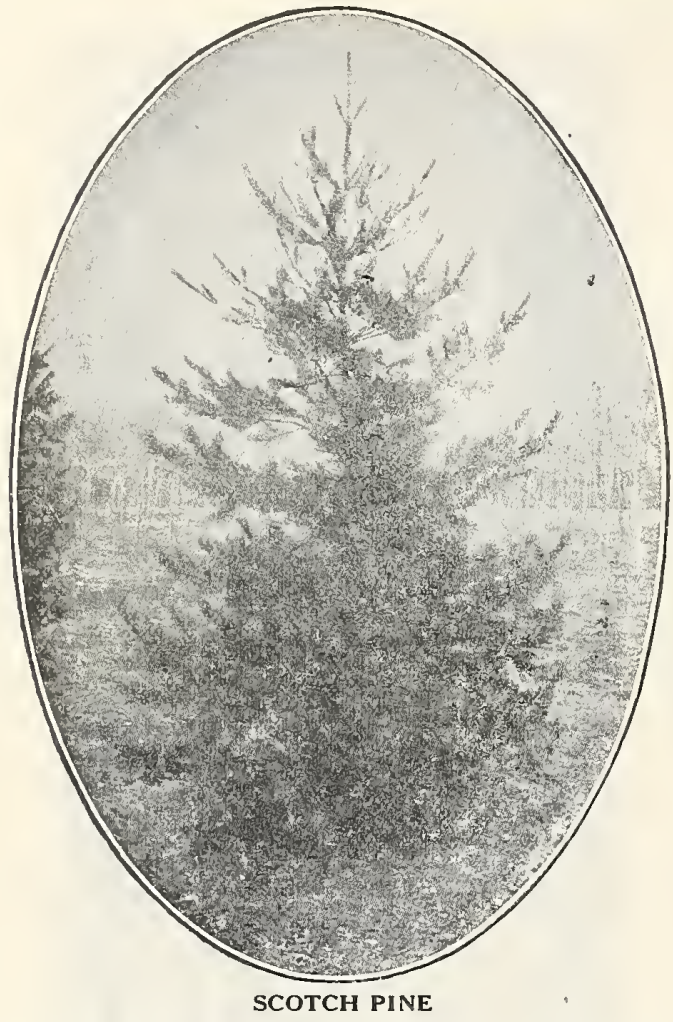

For your comfort beauty, economy and value of your place, there is nothing more appropriate than Evergreens. I have heard the remarks from seemingly well meaning persons that Evergreens made them sad, reminding them of a cemetery. How ridiculous! Evergreens today are perhaps the most fashionable of all ornamental trees, and if one Evergreen ever made us feel sad. it was because some other fellow had a specimen we did not have in our nursery.

Our Evergreens are extra robust and bushy and should be in every yard. By planting evergreens you will help carry out the ideal of the late President Roosevelt.

\section{EVERGREENS-}

Best Specimens for Lawn Planting and Grouping.

Arbor Vitea, globe.

Pinus Nigra Austriaca. (Austrian Pine.)

Pinus Strobus.

Pinus Sylvestris. (Scotch Pine.)

Thuya Occidentalis.

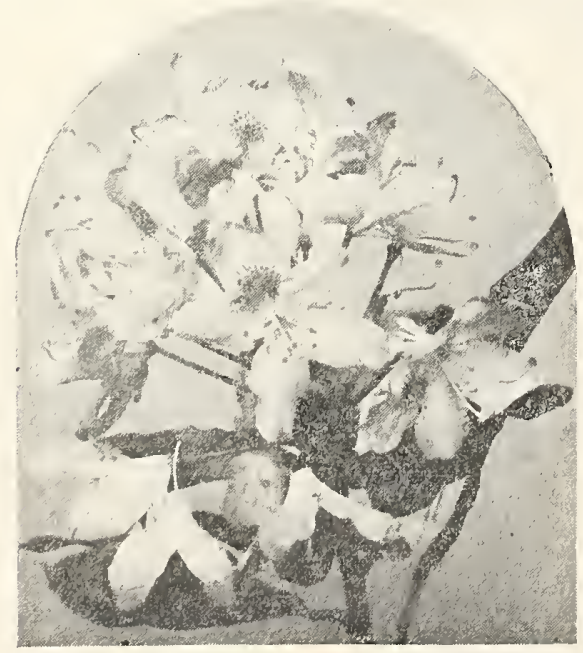

RHODODENDRON

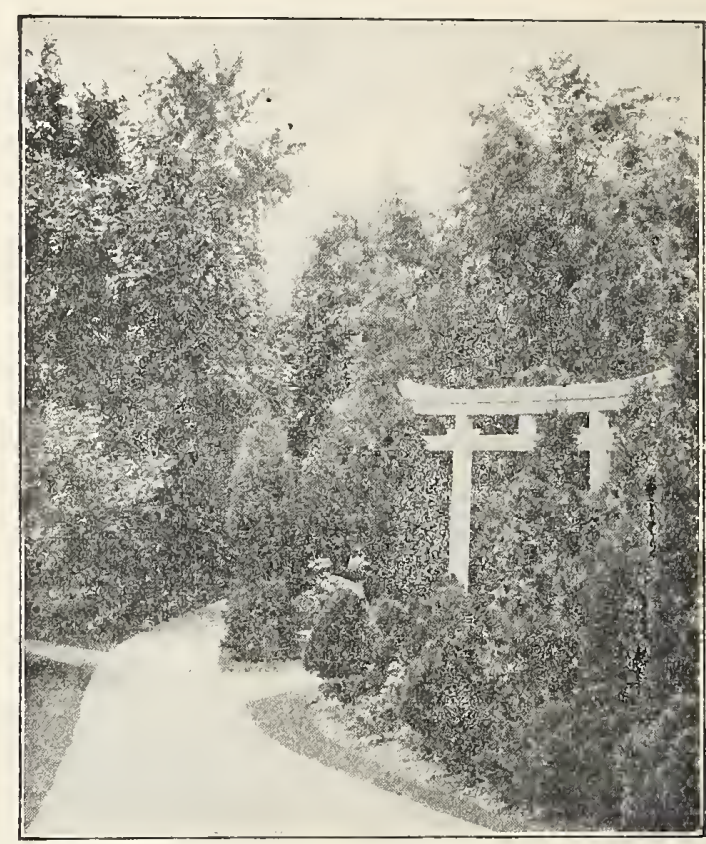

EVERGREWNS, WITH GLOBE AMBOT VITEI IN FOREGHROUND.

Picea Pungens, Var. Glanca (Colorado Blue Spruce.)

Picea Douglasli. (Douglas Spruce.)

Juniperus Virginiana

Abies Concolor, Concolor Fir.

We sell ony specimen size Evergreens. Each tree cary balled and burlaped so it retains several feet of earth.
3 to $4 \mathrm{ft}$., $\$ \$ .00$ each: $5 \mathrm{ft}$., $\$ 10.00$ each: $6 \mathrm{ft}$, $\$ 15,00$ each. EUONYMUS RADICANS VEGTUS. Beautiful Evergreen vine for planting on porches or trailing for ground cover. Thrives in shade. The contrast in winter of its beautiful red berries with its glossy green leaves makes a most striking sight. \$0.50 each; 6 for \$2.75.

\section{EVERGREEN VINES AND SHRUBS}

HAHONIA AOCIFOLIU⿴囗十 Beautiful Everom with Hollylike leaves and blue berries. In mid-winter the leaves change from a deep green to a shiny bronze red. Everyone should have this. Thrives in partial shade. Grows only about two feet high. $\$ 0.5$ each; 6 for $\$ 4.00$.

RHODODENDR,ON. Large bustes $\$ 5.00$ each.

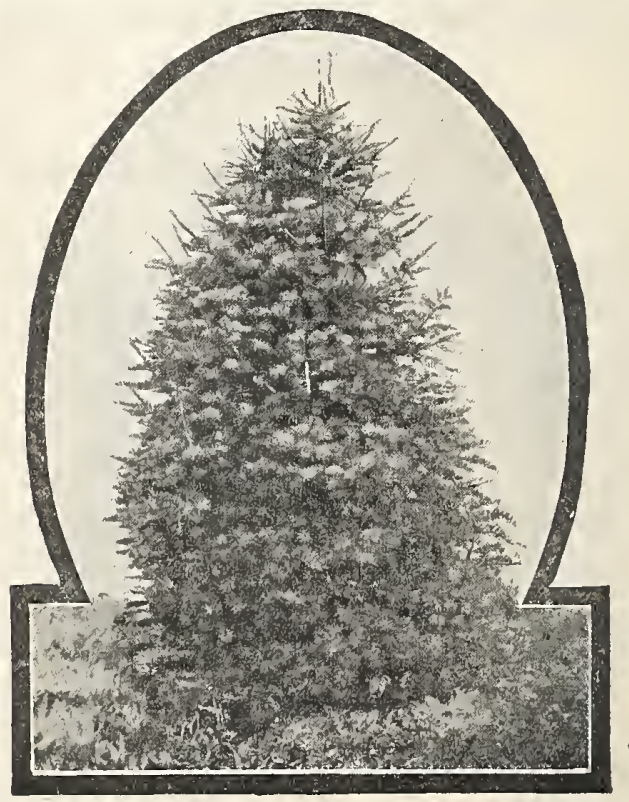

CONCOLOR FIR 


\section{SHADE TREES}

If you were looking for a home, one with large Trees, Shrubbery and Flowers would appeal to you most, wouldn't it? You often hear the remark of one envious neighbor to another: "I wish I had that beautiful tree in my yard." The Bryson Ayres Service has made it possible for you to have the kind of Tree you want in your yard. You do not have to wait years for them to grow, either. Our Trees are moved with the greatest of care.

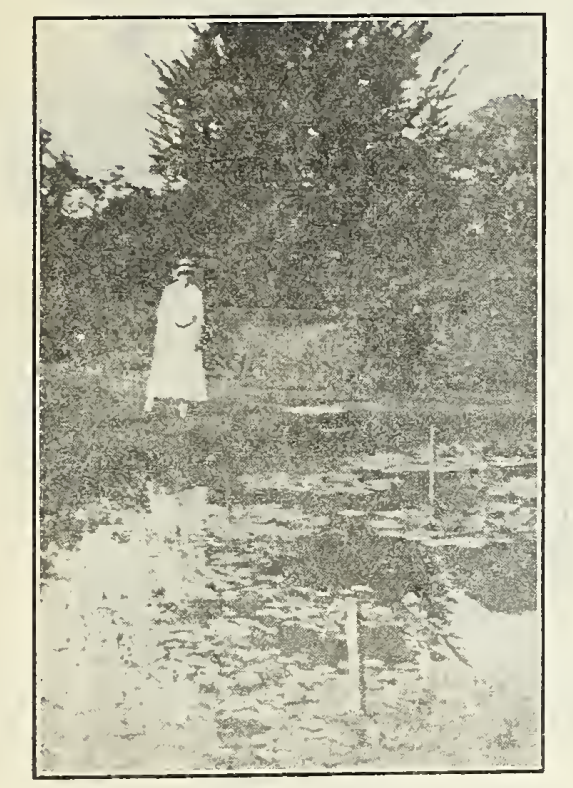

A. Corner at Harvard Botanical Gardens.

Cambridge, Mass.

\section{MAPLE.}

ACER SACCHARINIM. (Sugar Maple.) This beautiful tree will thrive in any scil. For shade, for beauty and satisfaction, and for real permanent worth in all landscape plainting, there are no other trees in its class. 8 to $10 \mathrm{ft}$., plainting, there are no other trees in its class, 8 to $10 \mathrm{ft}$., \$2.60; 12 to $14 \mathrm{ft}$. $13 /$ to 2 in. cal. $\$ 3.00 ; 14$ to $16 \mathrm{ft}$. 2 to $21 / 2$

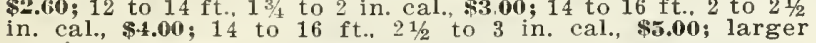
specimens, \$5.00 to \$25,00.

\section{BIRCH.}

BIRCH (Cut-leaf Weeping Birch). A most graceful tree with finely cut foliage. 5 to $6 \mathrm{ft}$., $\$ 2.50 ; 6$ to $8 \mathrm{ft}$., \$3.50. BIRCH PAPYRIFER . Pure white bark is the attraction of this tree. It will develop into a large, shapely tree, with good foliage. The best of all white Birches, contrasting beautifuliy with surrounding plants, especially evergreens. 4 to $5 \mathrm{ft}$., \$1.50; 5 to $6 \mathrm{ft}$., \$2.50; 6 to $8 \mathrm{ft}$., evergree.
$\mathbf{\$ 3 . 5 0}$.

\section{CATALPA.}

CATALPA (Umbrella Tree). The large, tropical-appearing leaves and rapid growth make the Catalpa very desirable. C. BungeI (Globe-Headed Chinese Catalpa). 7 to $10 \mathrm{ft}$. The dense, well formed, round head, on a straight stem about $5 \mathrm{ft}$. high, makes this an admirable tree for formal planting.

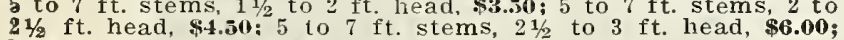
larger specimens, s.50 to sis.to.

\section{ELM-ULMUS.}

Ulmus Americana (American Elm). Our native Elm is too well known to need description. Just the tree for quick growth and is unsurpassed for city and suburb planting, growth and is unsurpassed for city and suburb planting,

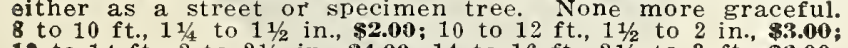
12 to $14 \mathrm{ft}$., 2 to $2 \frac{1 / 2}{2}$ in., $\$ 4.00 ; 14$ to $16 \mathrm{ft}$., $21 / 2$ to $3 \mathrm{ft}$., $\$ 6.00$; larger specimens, \$10.00 to \$25.00.

\section{LINDEN-TILIA.}

A quick grower, and a good shade tree. Fine for street or iawn use. The flowers are very numerous and deliciously fragrant, scenting the surrounding air.

'T. Americana. (American Linden or Basswood.) 50 to $60 \mathrm{ft}$. An attractive, fine, large-sized tree, of rapid growth, well suited for broad avenues, parks and public places, where it can develop. Special price, 5 to $6 \mathrm{ft}$., $\$ 1.50$ each.

\section{LIRIODENDRON-TULIP TREE.}

Tulip Tree. Liriodendron Tulipifera. (L). A grand native tree of rapid growth after it becomes established. A little difficult to transplant and small sizes are preferable for planting. 5 to $6 \mathrm{ft}$., each, \$2.50; 6 to $8 \mathrm{ft}$, each, $\$ 3.50$.

THE MULBERRY TREE-MORUS.

I. Tartarica. (Teas Weeping Mulberry). The sweet, fleshy fruits are a great attraction to birds and should be planted extensively. Grafted on stems about $5 \mathrm{ft}$. high, the pendulous branches completely hide the stems and sweep the ground. 5 to $6 \mathrm{ft}$., \$3.50 to \$5.50.

THE POPLARS-POPULAS.

A formal tree of pyramidal habit; very desirable for screen and wind breaks.

Carolina Poplar (Caroliniana), 10 to $12 \mathrm{ft}, 11 / 2$ to $2 \mathrm{in.}$ \$3.50; 12 to $14 \mathrm{ft}, 2$ to $21 / 2$ in. $\$ 4.50$.

Lombardy poplar. P. nigra. (fastigiata). Very decorative. Valuable for screening. 6 to $8 \mathrm{ft}$., \$1.00; 8 to $10 \mathrm{ft}$., $11 / 4$ to $11 / 2$ in., $\$ 1.5) ;$.10 to 12 ft.. $11 / 2$ to $13 / 4$ in., $\$ 2.50 ; 12$ to 14 ft., $13 / 4$ to 2 in., $\$ 3.60$; 14 to $16 \mathrm{ft}$., 2 to $2 \frac{1}{2}$ in., $\$ 4.50$. Special price on lots of 25 or more.

\section{FLOWERING PLUM-PRUNUS.}

P. Psardi. (Purple-Leafed Plum.) Bright purple leaves that hold their color all summer; fine when set in the background in group planting. 3 to $4 \mathrm{ft}$., $\$ 2.00 ; 4$ to $6 \mathrm{ft}$., $\$ 2.50$.

P. triloba. (Double-Flowering Plum.) This small growing tree is a great favorite; the branches are completely covered with double pink flowers in May; follage green. 2 to $3 \mathrm{ft}$., $\$ 1.30 ; 3$ to $4 \mathrm{ft}$., $\$ \mathbf{2 . 5 0}$.

\section{MALUS-FLOWERING CRAB APPLES.} Hardy little flowering trees that bloom abundantly in
Spring. Each year they are becoming more popular. Being of a somewhat dwarf nature adapts them for small lawns or for group planting on larger areas.

sweet Scented Crib. Malus coronaria. (S.) 4 to $5 \mathrm{ft}$, each, \$3.00.

I. florilunda. (S.) General effect of the flower is pink. 6 to $8 \mathrm{ft}$., each. $\$ 9.50$.

Bechtel's Double-flowering Crab. M. ioensis, var, Bechteli. (S.) Beautiful delicate pink flowers. Double and in bud form, almost as pretty as a rose. 2 to $3 \mathrm{ft}$, each, \$1.50; 3 to $4 \mathrm{ft}$., each, $\$ 2.50 ; 4$ to $5 \mathrm{ft}$., each, $\$ 3.00$

Parkman's F lowering Crab Apple. Malus Parkmanil. (S.) Bright rose-colored flowers. Because of the irregular growth of this particular variety it is best in groups or treated as a shrub. 3 to $4 \mathrm{ft}$., each, $\$ 1.50 ; 4$ to $5 \mathrm{ft}$, cach, $\$ 2.50 ; 5$ to $6 \mathrm{ft}$. each, \$3.00.

\section{PLANE TREE-PLATANUS.}

P. orientalis. (Plane or Buttonball.) The best street tree for cities. Of quick growth, spreading character, and with occasional pruning it develops into a shapely specimen. Prune severely when transplanted. 6 to 8 ft., $\$ 2.003$ 8 to $10 \mathrm{ft} .11 / 4$ to $11 \frac{1}{2}$ in. cal., $\$ 3.00$.

\section{WILD CHERRY.}

PRUNUS: WILD CHERRIES. Prunus Americana. (S.) to $5 \mathrm{ft} ., \$ 2.00 ; 6$ to $8 \mathrm{ft}$., $\$ 3.00$; larger specimens, $\$ 8.00$ to $\$ 25.00$.

\section{Remember the Bryson Ayres Landscape Service.}




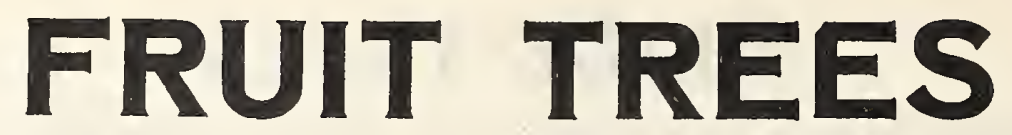

Fruit-growing as an industry has rapidly advanced in recent years; farmers are getting large returms from this source. The man with a small lot and the suburban acreage-owner are also interested as they find it fascinating as well as profitable. Our trees are straight, of moderate size, are guaranteed true to name, and, if given reasonably good care, will thrive.

APPLES.

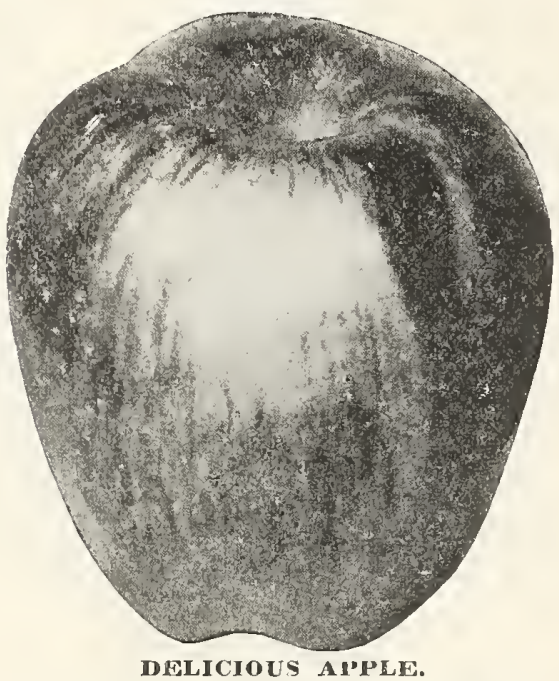

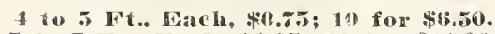

5 to 7 Ft., Esech, \$1.25; 10 for $\$ 11.00$.

We offer the very largest to be had and guarantee them

to be entirely free from scale and other diseases. BALDWIN. Large, bright red, rich, juicy. Winter.

BELLFLOWFR. Yellow, crisp, large and juicy. November. DELICIOUS. Large, unevenly shaped. Winter.

DUCHEs of oLDFiners. Medium. Striped red. Subacid. Fall.

GARLY IIARIAs'. Smalt. Straw color. Fine acid. July, IfALI, PIPPIN. Large. Yellowish creen. Delicious, Ocober.

GRIMES'GOLDEN MIPIN. Medium. Sub-acid. November. JONATHAN. One of our favorite fall and early winter varieties. Bright red.

RAMBO. Summer. Large, yellow; rich and of good flavor. August.

RED ISTRACHAN. Large, crimson, juicy, acid. July

RHODE ISLAND GRHNING. Large. yellow-green. Win-

SDOCFHOUSF. Medium, red striped. Sub-acid. Winter. STAYMAN'S WINESI'. Medium, bright red, Winter. YORIX IMPFRIAI. Medium, white, shaded red. Sub-acid. Winter.

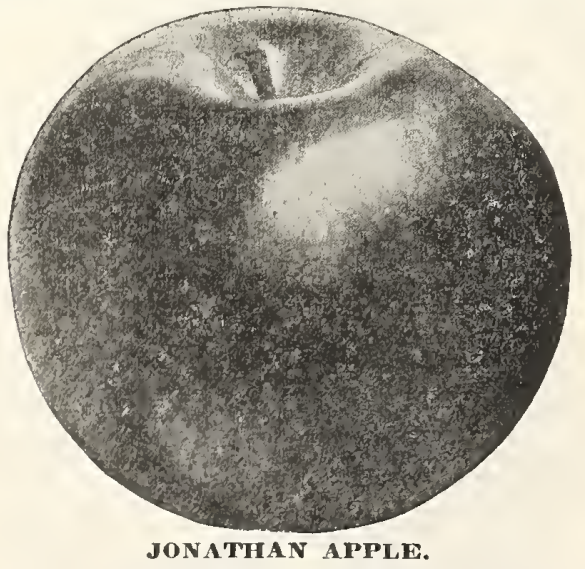

CRAB APPLES.

$\rightarrow$ to i Ft. Each. $\$ 1.00$

THANSCNDEN. "Medium, golden yellow, crimson cheek September. Strong, storky trees.

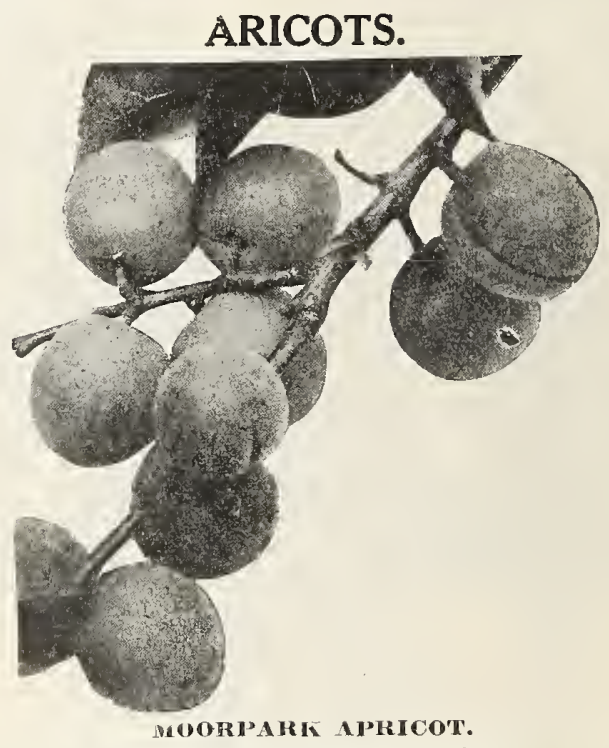

11 Varieties, Fach, $\$ 1.00$.

IAH Goluky Small pale orange. Juicy and sweet MonI IRI. Large, deep orange. Rich. August.

\section{PEACHES.}

1 to 5 Ift. Each $80.75 ; 10$ for $\$(6.5)$.

5 to 7 Ft., Wach, $1.00 ; 10$ for $\$ 850$.

(0ur pest that can be made.

They are hardy and all freestone varieties. delicious Late September. CRAWFORD WARII. Medium: yellow, July.
CRAWFORD's LITE. Very large, yellow, red cheek. Late September.

EI.HWR'TA. Very large, yellow, led cheek, juicy, rich. Middle of August.

IRov Io of August

(ID) IIION. Large, yellowish white, red cheek, pleasant. oliD MiNoN. Large,

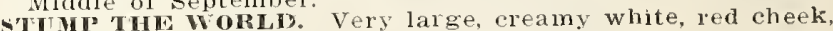
delicious. Soptember.

Wlicious s. Jolin. Large, yellow, sweet July.

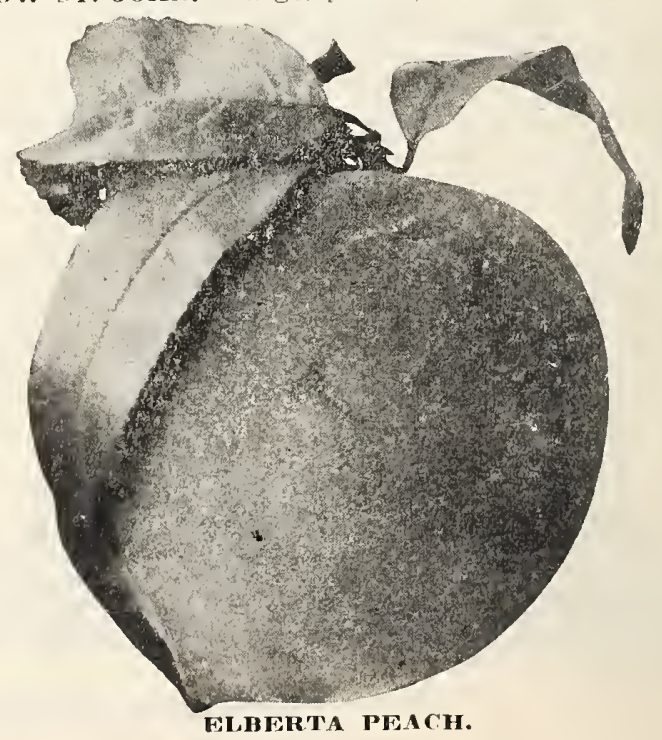




\section{FRUIT TREES-Cont.}

\section{CHERRIES.}

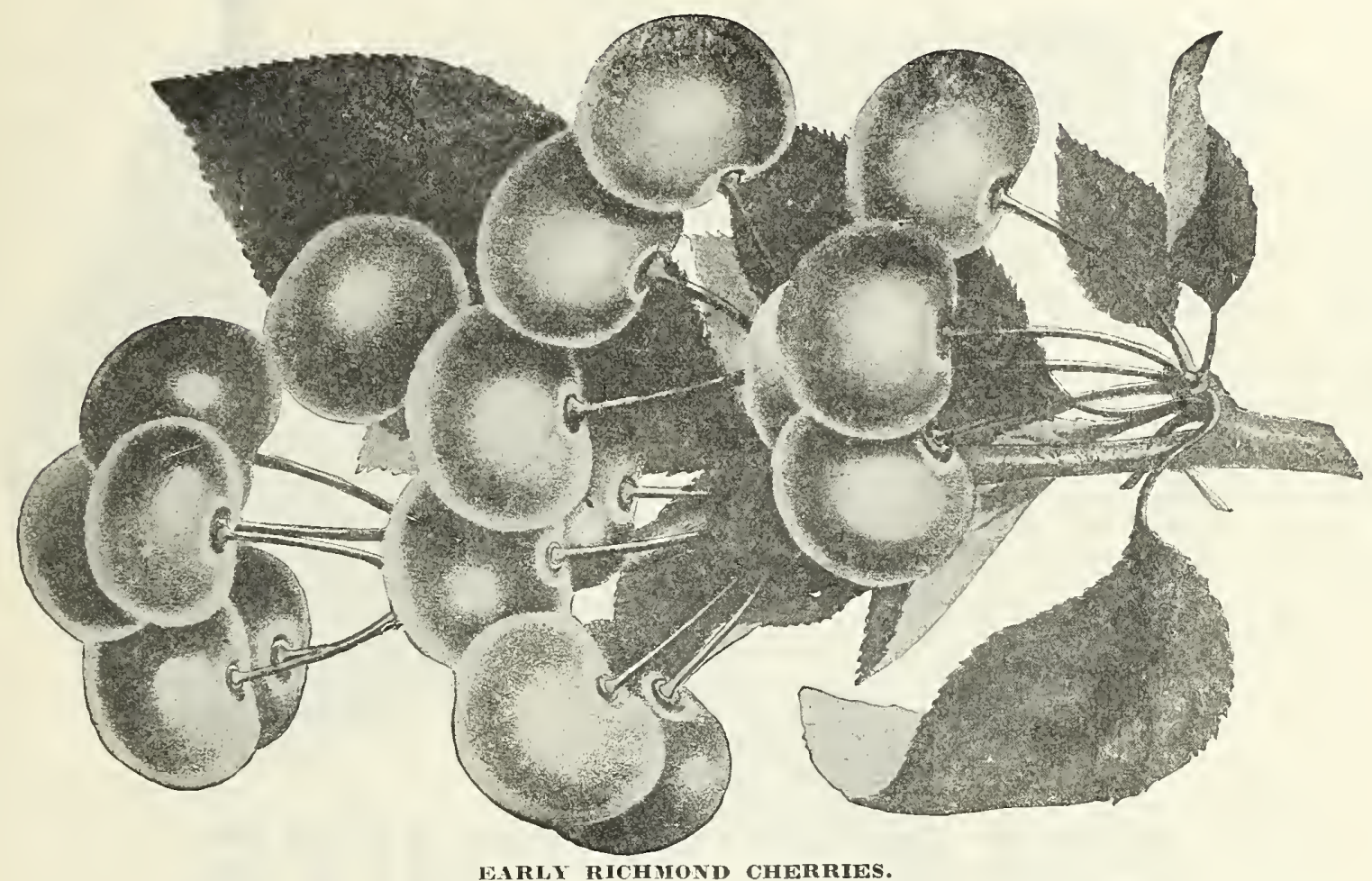

4 to 5 Ft., Each, \$1.00; 111 for $\$ \$ .50$.

5 to 6 Ft., Each, 1.25: 10 for $\$ 11.00$.

marl r Rohmond. Medium, deep red, rich, acid. Midrle
ENGLISH MorELLo. Large, dark red, pleasant, acid. Last of July.

MONTMORENCY. Large; bright red; pleasing acid flavor. June.

\section{PLUMS.}

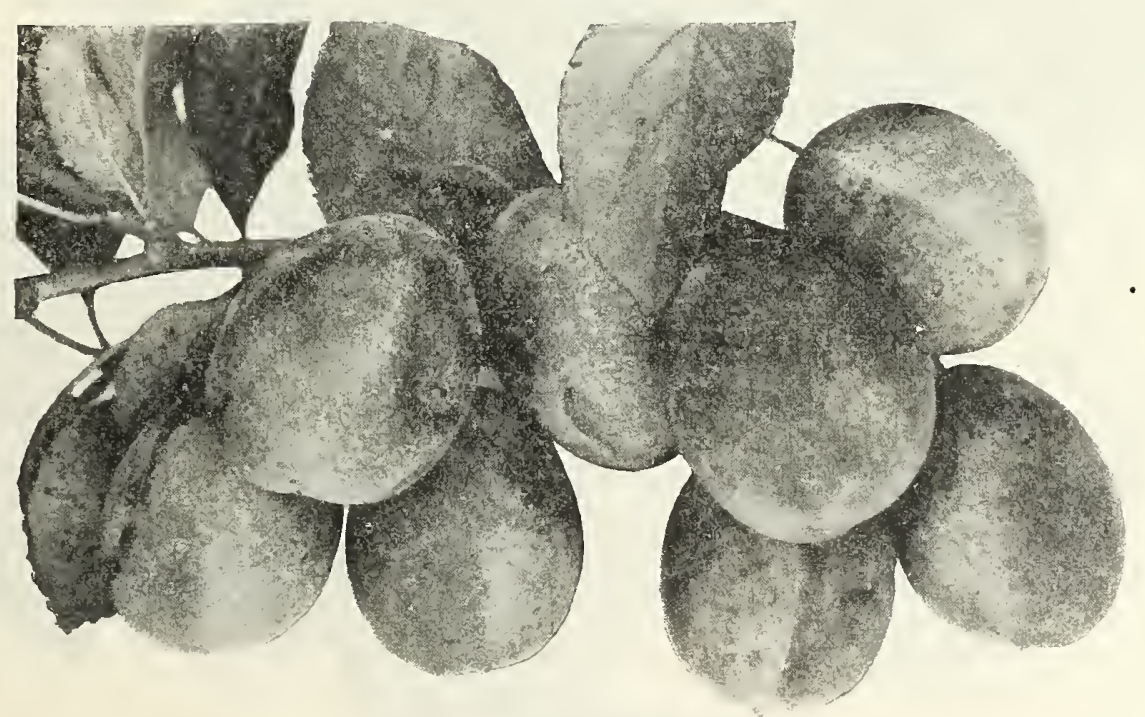

RED JUNE

1 to 5 Ft., Wach, $\$ 1.00 ; 10$ for $\$ 8.50$.

5 to 7 Ft., Each, \$1.25; 10 for $\$ 11.00$.

ARUNDANCF. Large, cherry-red, sweet. August.
HURHANK. Large, cherry-red, sweet Last of August. RED JUN. Large, purple-red Very early.

WH,D GoOsE. Most prolific. Fed. 


\section{PEARS.}

5 to 6 Ft., Each, $\$ 1.25$; 10 for $\$ 11.00$. BARTLETT. Large, clear yellow, highly aromatic. Sep-
tember.

BUERRE D'ClAIRgEAU, Large, russet, with red cheek. October.

DUChess D'ANGouleme. Large, greenish yellow, juicy. October.

HowelL. Medium, pale yellow, mildly sub-acid. September.

IXIEFFER. Large, golden yellow, sweet. October.

LAWRENCE. Medium, lemon-yellow, sweet. December.

SECKEL. Small, yellowish russet, spicy flavor. August to October.

SHELDON. Medium, greenish yellow, rich and aromatic. October.

VERMONT BEAUTY. Medium, yellow, red cheek, rich. october.
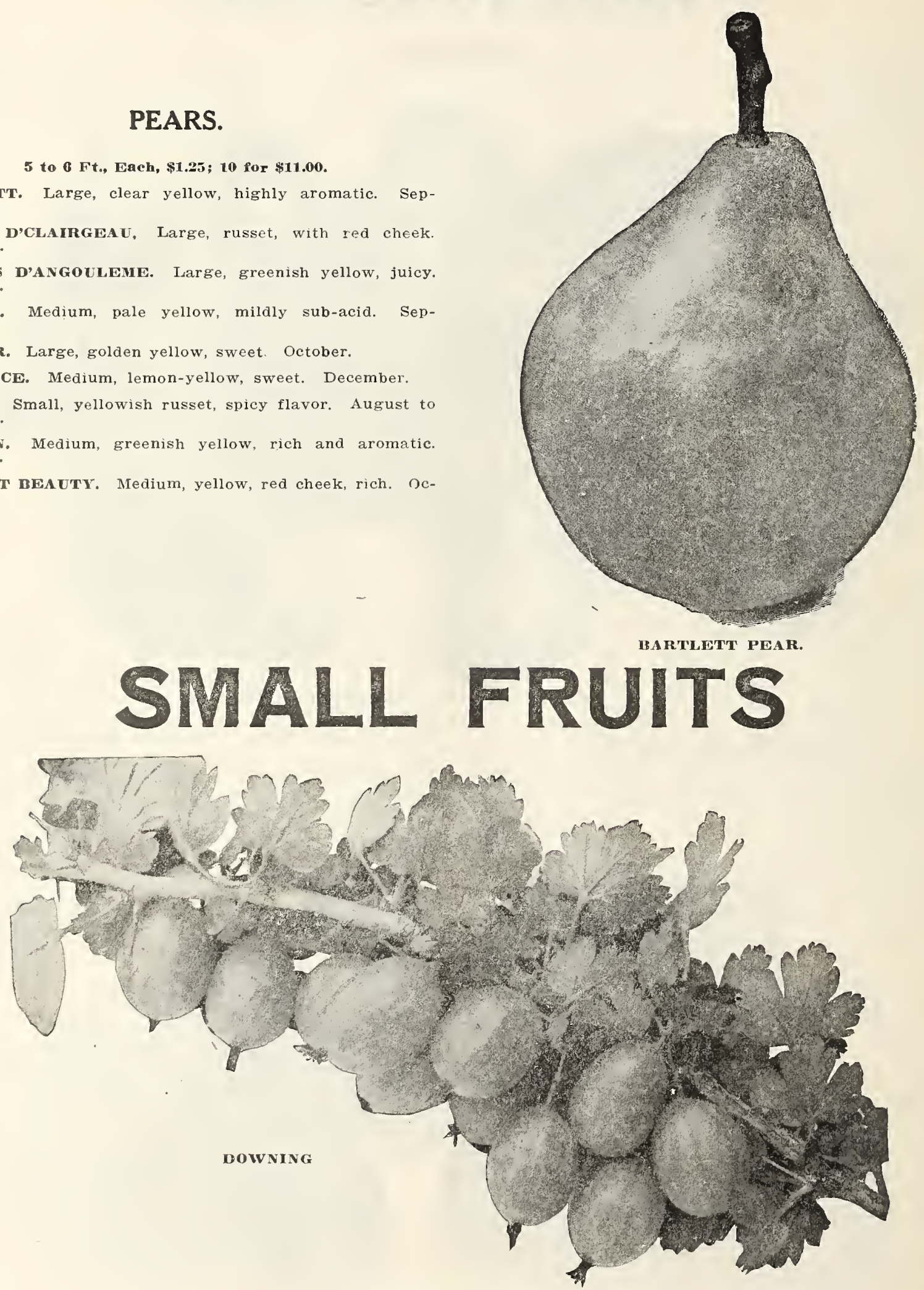

GOOSEBERRIES.

35e Eaeh ; $\$ 3.50$ Doren; Speeimen Bushes, Faeh, 50e.

Colunins. Very large and quite sweet. Approaches the old English varieties in size.

HOUGHTON. Medium size fruit and an excellent bearer. DownING. Extra large and of splendid quality. 


\section{Small Fruits-Cont.}

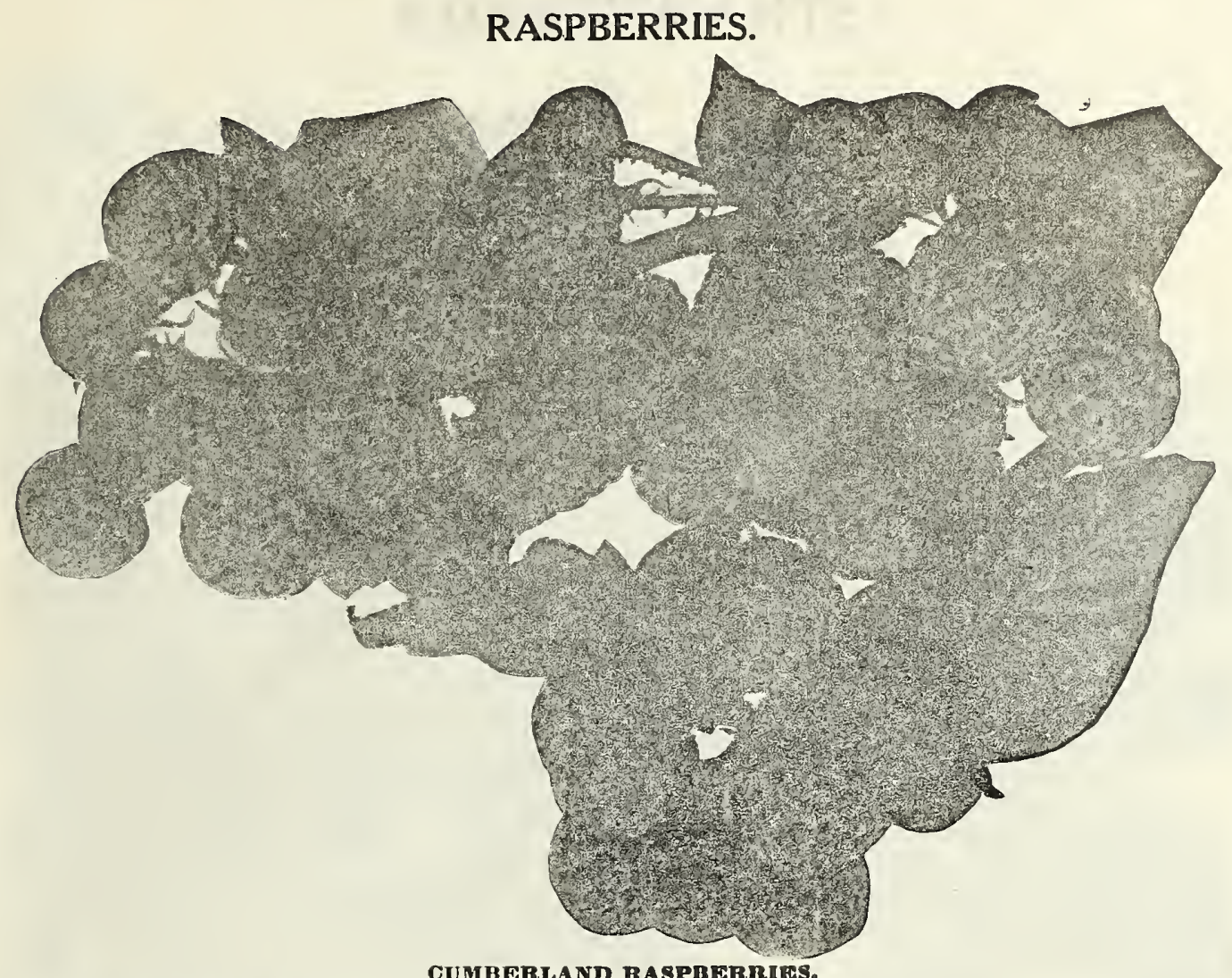

10e Each; 81.00 Dozen.

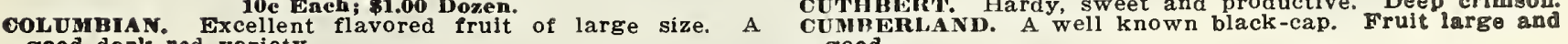
good dark red variety. good.

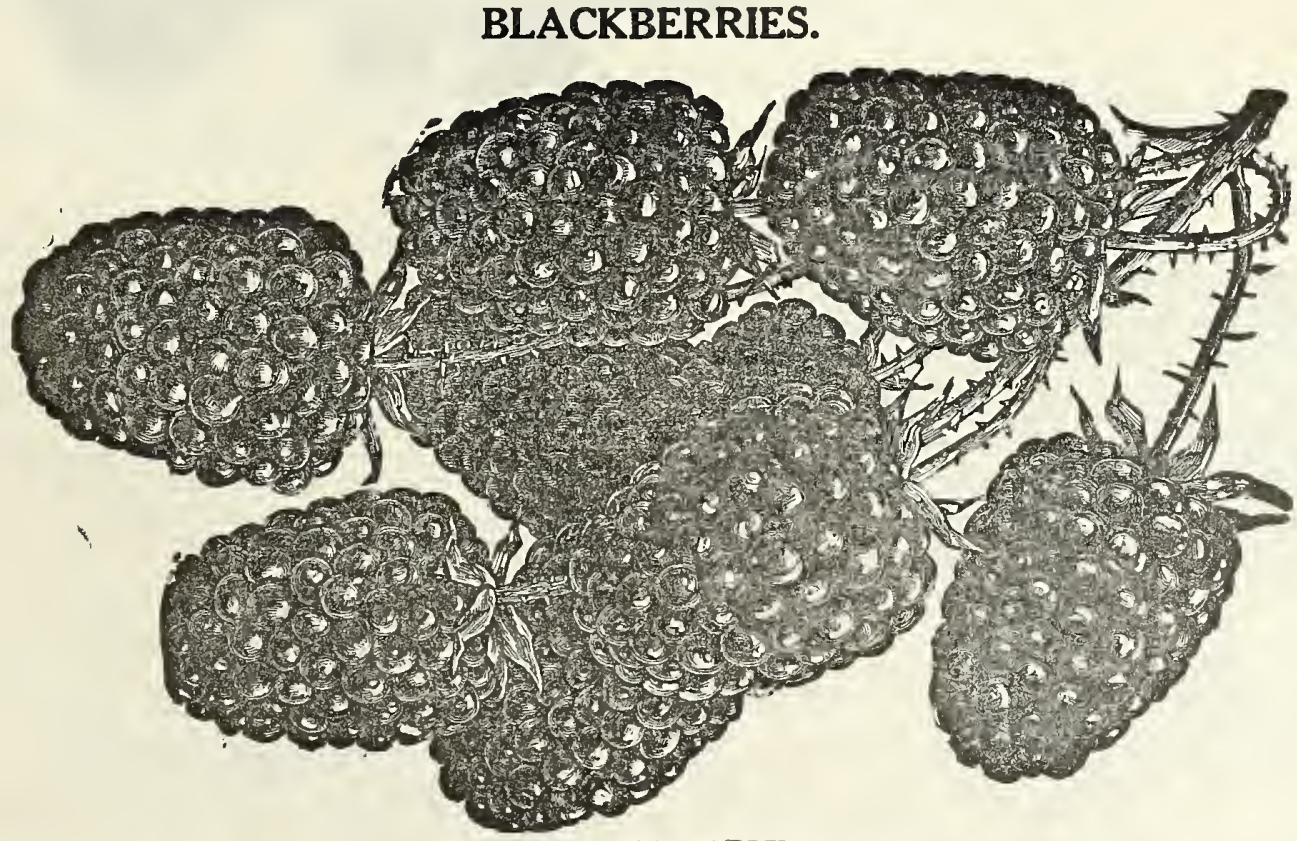

10c Each; $\$ 1.00$ Dozen.

WILSON'S GARLY. A hardy and productive variety. Fruit large, black and sweet. Good strong canes.
EARLY HARVEST. Extremely early and prolific.

SNIDER. Large berry. Mid-season.

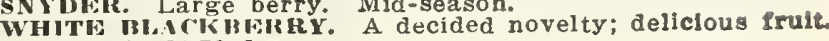
15e each $\$ 1.50$ dor. 


\section{Small Fruits-Cont. STRAWBERRIES}

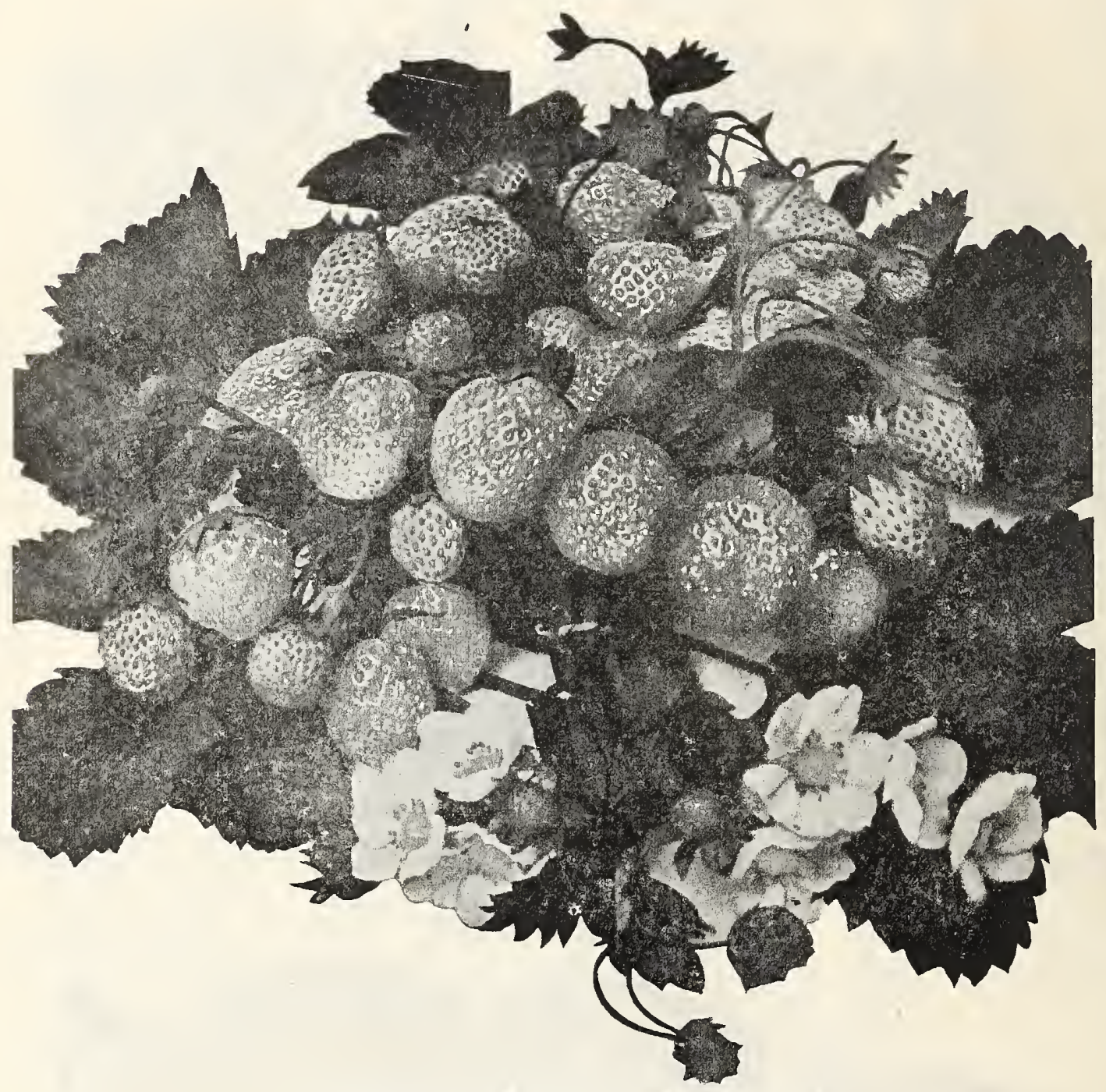

PROGRESSIVE EVERHEARING STRAWRERIRIES

\section{EVERBEARING STRAWBERRIES •}

The Everbering Strawberry has "made good" in commercial and home garden planting in widely varying parts of the country.

Plants set out in the spring will bear the same summer and with sufficient rain or artificial watering, will produce a good crop in the fall and continue to bear until heavy frosts come. The second year thoy nroduce a heavy crop in the spring, continue to bear throughout the summer if conditions are favorable, and give another heavy crop after the fall rains.

The plants are hardy, vigorous, and productive, and the foliage is unusually healthy. They succeed on all kinds of soil, can be planted on more fertile soil and in low land where frosts threatens the only crop of ordinary, or "standard" varieties.

All Strawberries require moisture and fertility to produce the best berries. This is especially true of the Everbearers, because of their prolific and continuous bearing habits.

After planting in the spring, the blossoms should be pinched off until about the first of July.

The best growing method with Everbearers is the Hill or Stool System. Set the plants 1 to $11 / 2$ feet apart in rows 3 to 4 feet wide. For the home garden. Set in beds 4 to 5 feet wide, with plants a foot apart. Be sure to cut off all runners.

Evelybearers should never be planted in the "Matted Row" or "Hedge Row" System.

To insure success, Everbearers must have greater fertility and more moisture than ordinary, or "standard" varieties. In the winter, give them a light dressing of well-rotted manure, which should be worked in by cultivation in the spring.

Owing to our immense acreage devoted to Everbearing Strawberries we offer herewith an unprecedended low price.

35e per do $z ; \$ \$ 1.00$ per $100 ; \$ 7.50$ per 1,000 . seldom without fruit during summer and fall.

SCPEIR EVERIEAlRiNG. Every garden should contain some of these. Prolific and very large.

$$
\begin{aligned}
& \text { PTOIIfic and very large. } \\
& \text { STANDARD VARIETIES. }
\end{aligned}
$$

$$
\begin{aligned}
& \text { STANDARD VARIFTINS. } \\
& \text { 40e Pex Do\%; } \$ 1.50 \text { l'er } 100 ; \$ 10.00 \text { Pex } 1,000 \text {. }
\end{aligned}
$$

The Strawberry will grow in any good garden soil, where the ground has been thoroughly prepared for family use. We list only varieties best suited to the soil in Missouri and Middle West.

Haverland

Aroma Scnator Dunlap

Wm. Belt

Early Ozark 


\section{Small Fruits-Cont.}

\section{GRAPES.}

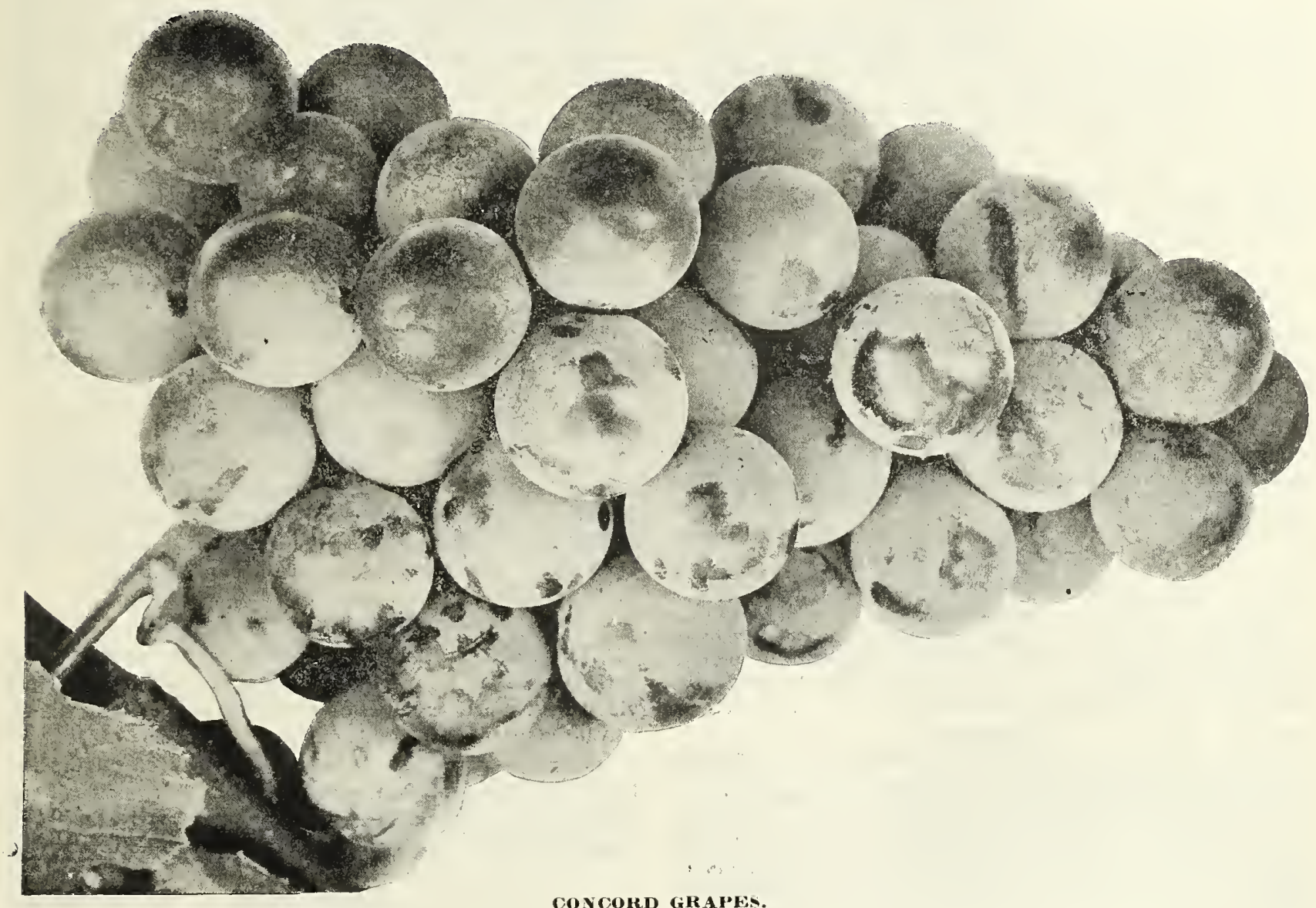

1 Year Old Vines, 25e Each; $\$ 2.50$ Per Doa.; $\$ 17.50$ Per 100. 2 Year Old Vines, 35e Each; \$3.50 Per Doz.; \$24.00 Per 100. 3 Year old Vines, 50e Ench; $\$ 6.00$ Per Doz.; \$40.00 Per 100 .

GRAPH-HLACK.

CAMPBELL'S EARLY. One of the largest fruiting Grapes and extremely satisfactory.

OONCORD. The well-known black Grape. Can always be depended on to fruit heavily.

WOHDEN. Bunch large and compact. Good large berries and an early fruiting variety.

$$
\text { GRAPE-RED AND PURPLE. }
$$

CATAWBA. A very nice berry, having an unusuálly sweet and aromatic flesh.

DELAWARE. The well-known small, very sweet red Grape. Comes in small bunches.

SALEM. Berries larger than Catawba, flesh tender, juicy and sweet.

\section{GRAPE-UVHITE.}

GREEN MOUNTAIN. A particularly fine white Grape and not well known as yet.

NIAGARA. This well known white Grape needs no desoription. It should be in every collection.

\section{ASPARAGUS.}

conover's colossal., and Harr's Mammoth Palmetto. $\$ 2.00$ per 100.

\section{RHUBARB.}

Strong roots of fine quality, \$1.00 per dozen.
CURRANTS.

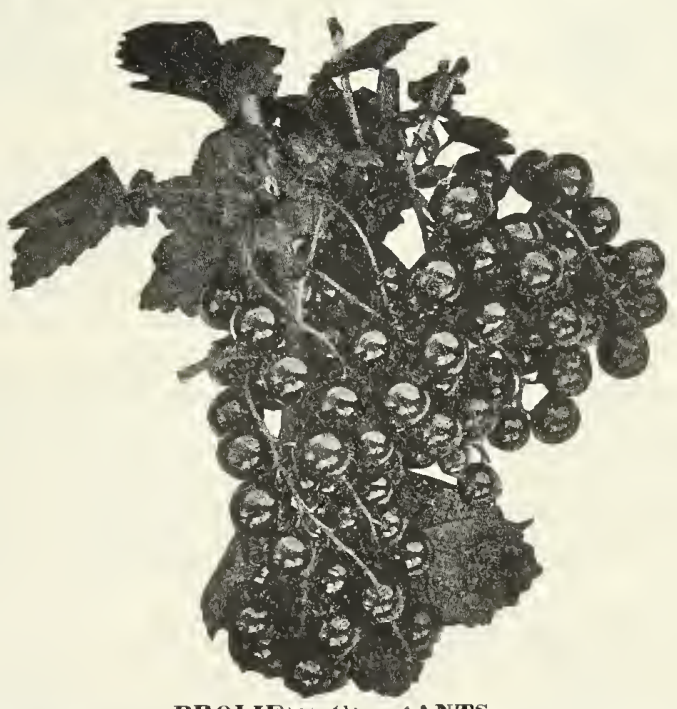

PROLIFIC CunkANTS

FAY'S PRoLIFIC. This red has been known for years as a dependable variety. Strong, healthy plants. wach, 35e; $\mathbf{8 3 . 5 0}$ per doz. Specimen bushes, each, 50c: \$5.00 per doz. 


\section{INSECTICIDES, FUNGICIDES, DISINFECTANTS}

We cannot send liquids or poisons through the mails, so that all Insecticides go by express or freight, not prepaid, unless quoted by parcel post.

\section{PARIS GREEN}

For liquid spraying. Use I pound of Paris Green to 100 or 200 gallons of water, according to strength desired. It will be found generally strong enough if $1 / 2$ pound is stirred in a barrel (50 gallons) of water, and allowed to stand twenty-four hours before using. Care must be taken in using all poisonous liquids that animals are not allowed to get at them. In powder form, use 1 pound of Paris Green and 20 to 50 pounds of flour; mix thoroughly, apply evenly, preferably when dew is on plants. Prices on application.

\section{LIME-SULPHUR SOLUTION.}

The best remedy for San Jose scale and other scale insects on trees and shrubs. Use 1 gallon to 20 gallons of water during December and January, but earlier or later dilute 1 gallon to 40 gallons of water. Prices on application.

\section{CALCIUM-ARSENATE.}

(Dry or Paste)

It can be applied, pure or reduced, with any of the dusting machines or guns. From 1 to 30 pounds per acre should be used. In water, for most purposes, use from 1 to $11 / 2$ pounds of the dry or 30 pounds of the paste to 50 gallons.

\section{DEVOE BORDEAUX MIXTURE. Dry Powdered Form. Fungicide.}

To Control Scales and Blight. For all Fungous Diseases. The best Fungicide for curing or preventing blotch, rot, mildew, blight, leaf curl, scab or other fungous diseases on fruit and plants, if used dry.

\section{Directions.}

For potatoes, dust without reduction, 4 to 5 pounds per acre (according to size of vines).

For fruit trees, dust after reducing 1 pound of Dry Bordeaux with 20 pounds of lime dust.

For spray, to make the equivalent of 4-4-50 mixture, use 8 pounds of Dry Bordeaux Mixture to 50 gallons of water. For 5-5-50 mixture, use 10 pounds to 50 gallons of water.

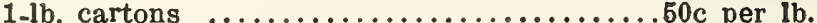

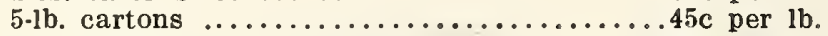

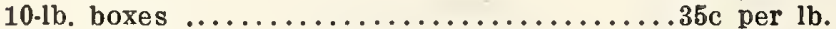

25-lb. drums .....................29c per lb.

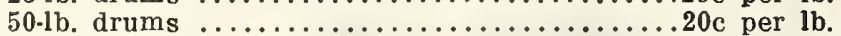

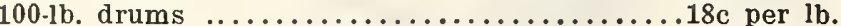

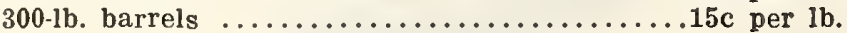

ARSENATE OF LEAD.

Our stock of this is strictly fresh, from one of the best factories in the country, and will be found the best spraying preparation in the entire list for the destruction of insect pests. Use 3 pounds to 50 gallons of water, or, if preferred, use 50 gallons of Bordeaux mixture instead of water for dilution. Prices on application.

\section{DEVOE "SURE NOXEM.”}

Dry Powdered Form. Insecticide to Most Leaf-eating insects.

One of the best vegetable Insecticides in use. Specially recommended for destroying worms and insects.

For cabbage, cauliflower, tomato plants, cucumber vines, melon vines, currant bushes, gooseberry bushes, vegetables and flowers of all kinds attacked by leaf'eating insects.

1-lb. sifter-top cartons ..............20c per lb.

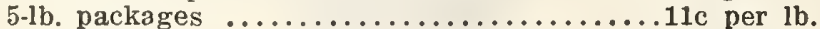

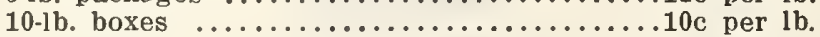

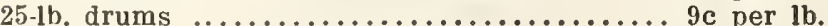

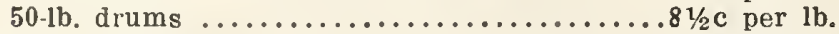
100-lb. drums ..................... 8c per $1 b$. $300-1 b$. barrels ....................

\section{PRATT'S DIP AND DISINFECTANT.}

Stands at the top as the one successful way to insure healthy animals and clean quarters.

Scarcely less important than proper feeding is the necessity for having clean quarters for live stock and poultry. Unless stables and poultry houses are kept thoroughly cleaned and disinfected, a host of troubles is sure to follow. Blood-sucking ticks and mites and skin diseases, such as eczema and ringworm, are typical enemie of stock, causing them in a short time to be in run-down condition and an easy prey to disease.

Cures horses of mange, lice, eczema, ringworm, thrush, and is a perfect remedy for galls, sores, and similar wounds.

Hog cholera is unknown where Pratt's Dip and Disinfectant is used. Rids hogs of lice and ticks and cures all skin troubles.

Sheep ticks, the great f'oe of sheep, are destroyed, and other sheep diseases, such as scab and foot-rot, are cured. Use it freely at lambing time. I gallon, $\$ 1.25 ; 1 / 2$ gallon, $75 \mathrm{c} ; 1$ quart, $45 \mathrm{c}$.

\section{BLACK LEAF.}

A solution of nicotine sulphate especially adapted for outdoor spraying against aphis and soft-bodied sucking insects. Follow instructions carefully. A small bottle makes 6 gallons; each 25c. 1/2 lb. makes 40 to 100 gallons; each 75c. 2-lb. cans, $\$ 2.50 ; 10-1 b$. cans, $\$ 10.25$.

\section{THE STANDARD SPRAY PUMP.}

The Standard Spray Pump is in reality simply a very carefully designed and accurately made "squirt gun" provided with a proper outfit of nozzles.

Its plan of operation is quite different from other types of spraying apparatus, since the hose is used on the suction end instead of the discharge end. This makes it possible to use the oump with a bucket, barrel tank, or knapsack, depending upon the number of trees or the kind of spraying to be done.

For bucket use a $3 \frac{1}{2}$-foot length of hose is supplied. To use it with barrel or tank for a large orchard, a longer hose up to 25 or 30 feet is desirable.

The Standard is provided with a set of three nozzles.

Price of complete outfit, $\$ 15.00$, including Standard Spray Pump, Nozzle, 5-gallon Galvanized Knapsack, and Brass Extension Rod for spraying potatoes, tomatoes or other truck. We guarantee satisfaction or money returned.

\section{LIGHTNING BARREL SPRAY PUMP.}

The Lightning Barrel Spray-Pump has great capacity and will throw a solid, continuous stream of any size spray desired. The air is compressed into the air chamber, thereby giving an unbroken stream; with one stroke of the pump handle, the pressure is retained so that the working of the pump handle is very slow, and yet gives a great force of water, which is accomplished by the compressed air chamber, making it the most rapid Spray Pump made. The agitator thoroughly stirs the liquid and prevents it from settling. It is provided with a brass strainer in the bottom of the suction barrel. The suction barrel is made of heavy brass, ground together so that all parts fit absolutely air-tight, and will not corrode or rust out. This pump is easily and quickly adjusted to any barrel provided with means of bolting to the staves of the barrel at upper end. Complete with 15 f'eet of hose, base and agitator, $\$ 20.00$, 


\section{HIGH-GRADE FERTILIZER}

Good profits can only be obtained from good crops. Good crops can only be produced from good soil. There is only one way to keep soil good, that is, to use a fertilizer in some way or other; must either use stable n.anure commercial fertilizer, or plow under a green manure, such as clover, cow peas, soy beans, vetches, etc. Stable manure often contains many weed seeds, and the ground must be idle for a crop of clover or a green fertilizer for at least one season; therefore we recommend Commercial Fertilizers, such as Pulverized Sheep Manure, Bone Dust, Nitrate of Soda, where quick results are wanted.

Good Fertilizer will prepare the soil so that it can be depended upon to produce good crops. To those, if any there be, that doubt the efficacy of fertllizing the land, we say, try an acre or two as an experiment. The result will speak for itself. Our prices include sacks and cartage to depot in Kansas City, Mo., 1,000 pounds of one klnd at ton rate, except where 500-pound or 1,000-pound price is quoted. We cannot break bags except as noted.

Practical Fertilization.-To enable the farmer to understand more thoroughly the science of fertillzation, we here dwell lightly upon the required elements for production of maximum crops:

\section{SWIFT'S PLANT FOOD.}

An odorless concentrated soluble fertllizer for house plants. A package is sufficient for 30 plants for 3 months. 5 lbs., $40 \mathrm{c} ; 10$ lbs., $70 \mathrm{c}$.

\section{FRUIT AND ROOT CROP GROWER.}

For fruit trees and small fruits, garden truck, tobacco, potatoes, sugar beets, etc. Quick in starting, lasting in effect, giving firm, healthy growth and developing the fruit. Use 250 to 500 pounds per acre. Analysis, 2-10-1/2. 125 lbs., \$3.50; 250 lbs., \$6.75; 500 lbs., \$13.00.

\section{POTATO GROWER.}

This fertilizer is of special use for the potato crop and is also adapted for sweet potatoes, vines, fruit trees and all leguminous plants. It contains lots of potash-just what potatoes need. Use 1 t at the rate of 250 to 500 pounds per acre. Analysis, 3-8. 125 lbs., \$3.50, 250 lbs., $\$ 6.75$.

\section{GRAIN GROWER.}

For general farm use, but especially adapted for the growing of all cereals. Use at the rate of 250 to 500 pounds per acre. Analysis, 2-8. 125 lbs., \$3.50; 250 lbs., $\$ 6.75$.

\section{CORN GROWER.}

Contains a large percentage of phosphoric acid and potash, the most essential elements in the production of a maximum corn crop. Nitrogen is also supplled in surficient quantity to form a well-balanced complete fertllizer. An excellent brand for black soils. Use 250 to 500 pounds per acre; half broadcast, balance in hills or drills, mixing thoroughly with the soll before planting. Analysis, 1-12-1. 125 lbs., $\$ 3.45 ; 250$ lbs., $\$ 6.50 ; 500$ lbs., $\$ 12.50$.

\section{BONE MEAL.}

Highest Grade.-It is ground fine and is an excellent top dressing for lawns, grass lands, farm and fleld crops, also for mixing with potting soil. $100 \mathrm{lbs}$., $\$ 3.00$.

\section{AMMONIA OR NITROGEN.}

Tends to promote leaf or foliage growth. You will find it in various combinations. In the form of salts or nitrates, is readily available. All Ammoniates must be reduced to soluble salts by the soil bacteria before they can be taken up by the plant. By the application of Ammonia on land that is low in humus, the general foliage and root growth is stimulated and the amount of vegetable matter in the soil is multiplied many fold; in other words, humus is grown. Ten per cent. $\$ 3.25$ per 100 lbs.

\section{PHOSPHORIC ACID.}

Tends to ripen the plant earller, bring out full. solid kernels in grain and give color to fruits and vegetables. A moderate application of Phosphoric Acld, in hastening maturity, will get your fruit and vegetable crops on the market ten days or two weeks earller than if not fertilized. This will often more than double returns from your crops. Twenty-six per cent, $\$ 3.00$ per 100 lbs.

\section{POTASH.}

The importance of this element should not be overlooked. It acts as a strong feeding tonic to all crops, giving healthy body to grain and luscious flavor and ilgh eolor to fruit. In the form in which we carry it, it is a won. derful insecticide and funglcide. For root affections of grain and forage crops and scab, etc., of potatoes and other truck it is unequaled; no market product, the keeping qualities and general appearance of which is desired to be first-class, should be grown without an application of Potash. Ask for prices.

\section{NITRATE OF SODA.}

Nitrate of Soda is not a substitute for other manures, but we recommend it as the cheapest and best form in which to apply Nitrogen to plants. Gardeners who are using farm manure should continue to use it, but use Nitrate of Soda in addition to other fertilizers. If your object is to grow maximum crops, you must in some way furnish the plants with Nitrogen. No matter what manure or fertilizer is used, the Nitrogen must be converted into Nitrate before the plants can use 1t. Price (subject to market changes), lb., 15c; 5 lbs., 65c; 1 lbs., \$1.15; 25 lbs. $\$ 2.50$.

\section{SHEEP MANURE.}

This fertilizer is dry, pulverized and screened and all undigested weed seeds have been destroyed so they cannot under any circumstances germinate. The analysis is: Ammonia, 2.73 per cent; phosphorlc acld, 1.75 per cent; potash, 1.50 per cent; humus, 90 per cent. Thls is one of the best and strongest fertilizers. It produces steady and rapid growth and 18 very convenlent to handle and easy to use. There is no objectionable.odor. It is especially desirable for lawns, but is also one of the best fertillzers for truck gardens and for green-houses. 100 lbs., \$2.75, 500 lbs., $\$ 12.50$.

For Lawns.-Pulverlzed Sheep Manure is the best possible for the lawn. It should be applled by sprinkling lightly over the grass, same as one would sow grass seed. It requires no raking in. The color is not conspicuous and there is no objectlonable odor.

For the Garden.-After the crop has been harvested in the fall, the garden should be given a good coating of Sheep Manure. In the spring put on another light coat and turn it under, or sow lightly in the rows. By the use of this fertillzer large crops will result; they will mature early and they will be of superlor quality. This product is the best fertiizer for the home garden yet offered.

For Public Parks.-Sheep Manure is used on some of the best public parks in this country, including the beautlful park system of Kansas City. It is more elficlent, easler to apply, and has less odor than other fertllizers, and does not have to be raked in.

For Truck Garden.-Sheep Manure is the best fertllizer for the truck garden, produclng better and earller crops of onions, celery and other vegetables.

For Flower Beds.-Free blossoming can be induced, or increased, by judicious use of Sheep Manure. Sprinkle it carefully in the beds, and both follage and blossoms will be large and vivid in color. A teaspoonful or so stirred In the soil about the roots of each plant two or three times during the season will give you astonishing results. Always water plants thoroughly after fertilizing. $\$ 2.50$ per 100 lbs. 
VEGETABLE SEEDS

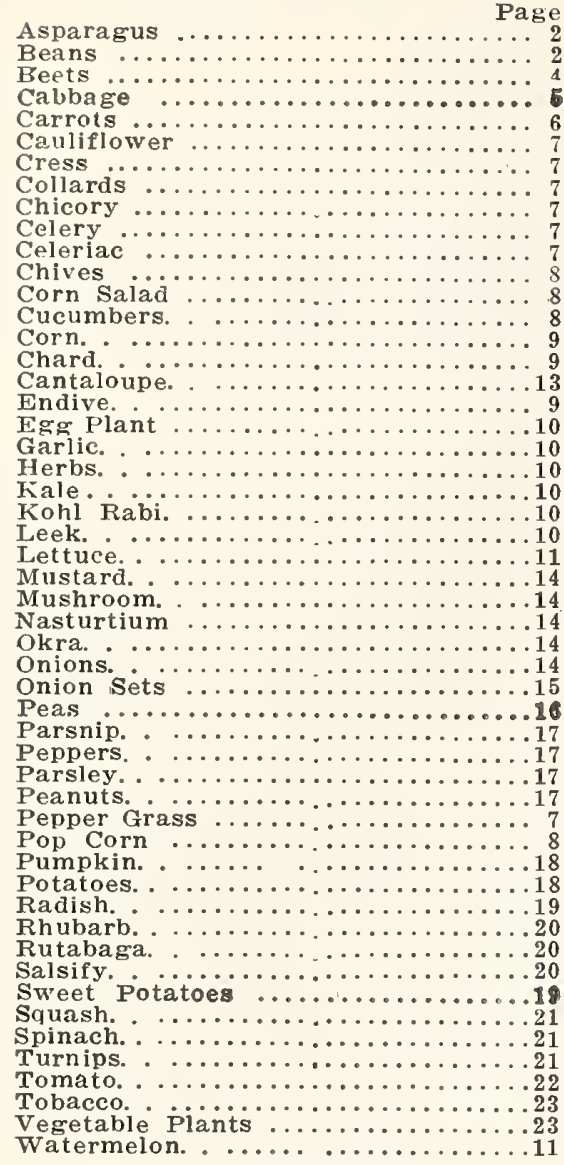

Alfalfa

FIELD SEEDS

Broom corn

Broom Corn

Corn.

Cow Peas

Clover.

English Biue Grass.

Feterita.

Field Peas

Grass Mixtures

Kaffir Corn

Millet

Milo Maize

Oats.

Orchard Grass

Peanuts.

Red Top

Rye

Rye or Soja Bëans.

Sunflower.

Sudan Grass

Timoth

FLOWER SEEDS.

All Varieties AYRES CELOSIA.

See Special Page.

\section{Flower Seeds}

Asters.

Acrolinum.

Aquilegis.

Amaranthus.

Arctotis Grandis

Ballown vine

Brachycome.

Calendula.

Calliopsis.

Campanula.

Carnation.

Celosia.

Celosiamum.

Chrysanthemum.

Centaurra.

Chinese Lantern Plänt

Clarkia.

Coroca scandens

Columbine.

Coreopsis.

Cosmos.
Cucumber vine ............ Page

Cucumber vine $\ldots \ldots \ldots \ldots \ldots \ldots \ldots \ldots \ldots \ldots 39$
Delphinium. $\ldots \ldots \ldots \ldots \ldots \ldots \ldots \ldots \ldots$

Daisy. Dianthus. $\ldots \ldots \ldots \ldots \ldots \ldots .39_{39}$

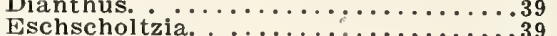

Eschscholtzia.

Euphorbia.

Feverfew. - Fot

Four o'Clock

Gaillardia.

Geranium

Godetia.

Gomphrena.

Gourds.

Grasses.

Gypsophila.

Helichrysum.

Heliotrope.

Hyacinth Bean

Kochia.

Larkspur.

Linaria.

Linum.

Lobelia.

Hunnemannia.

Marigold

Mignonette.

Morning Glory

Nicotiana.

Nigella

Pansy.

Petunia.

Phlox.

Physalis.

Poppies.

Salpiglossis.

Stocks.

Straw Flowers

Sun Flower

Verbena.

Wallflower

Zinnia.

SiviET PEAs.

Spring Flowering

Summer Flowering

Cultural Directions $\ldots \ldots \ldots \ldots \ldots . . . .43$

AUMMER BuLBS

Amaryllis.

Caladium

Cannas.

Funkja.

Gladiol.

Hemerocallis

Hardy Lilles

Lily of the Valley

Tiger Lily

Maderia Vine

Tube Rose.

Dahlis.

LANDSCAPE DEPT.

Ornamental Flovering Shrubs.

Althea.

Barberry.

Butterfly Bush

Currant.

Crab

Calycanthus.

Deutzia.

Dogwood.

Desmodium.

Elder.

Forsythia.

Fringe.

Honeysuckle.

Horse Chestnut

Hydrangea

Lilac.

Locust.

Plum.

Privet.

Pea Tre

Snowball.

Snowberry.

Spirea.

Sumac.

Syringa.

Tamarix.

Weigela.

Hybrid Perpetual Roses..............49

Novelty Roses .........................

HARDY PERENiYA L.

Hot and Dry Place Perennials........51

Place Perennials.......5

Agrostemma.

Alyssum.

Anchusa.

Anemone.

Aquilegia
Aster.
Barbatus. . . . . . . . . . . Page

Bocconia. . .................

Boltonia. $\ldots \ldots \ldots \ldots \ldots \ldots \ldots \ldots \ldots \ldots$. $\ldots 1$

Campanula. : $\ldots \ldots \ldots \ldots \ldots \ldots \ldots \ldots \ldots \ldots$

Carnation. . . . . . . . . . . . . .

Centourea. . . . . . . . . . . . . 51

Cerastium. . .............. 51

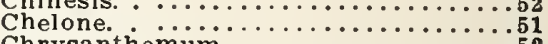

Chrysanthemum. .............

Convallaria. . .............. 52

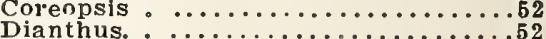

Dianthus. $\quad \cdots \ldots \ldots \ldots \ldots \ldots \ldots \ldots \ldots \ldots \ldots 2$

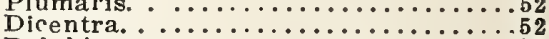

Delphinum. . .................

Formosum. . . . . . . . $\ldots \ldots \ldots \ldots \ldots$

Gaillardia. $\ldots \ldots \ldots \ldots \ldots \ldots \ldots \ldots \ldots \ldots \ldots \ldots$

Gypsophila. .............. 52

Golden Glow .............. 52

Helenium. . .............. 52

Helianthus. $. \ldots \ldots \ldots \ldots \ldots \ldots \ldots . . \ldots 2$

Hemerocallis. . . . . . . . . . . 52

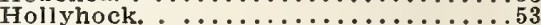

Hibiscus. . .............. 53

Iberis. . $\ldots \ldots \ldots \ldots \ldots \ldots \ldots \ldots \ldots \ldots 3$

Iris. ${ }^{2} \ldots \ldots \ldots \ldots \ldots \ldots \ldots \ldots \ldots \ldots . \ldots \ldots 3$

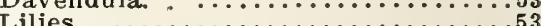

Peonies....$\ldots \ldots \ldots \ldots \ldots \ldots \ldots \ldots \ldots \ldots 4$

Phlox.$\cdots \cdots \cdots \cdots \cdots \cdots \cdots \cdots$

Papaver. ...................

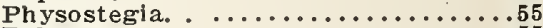

Polygonum. .......................

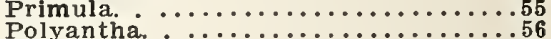

Polyantha. $\cdots \ldots \ldots \ldots \ldots \ldots \ldots \ldots \ldots \ldots \ldots \ldots \ldots$

Pyrethrum. . $\ldots \ldots \ldots \ldots \ldots \ldots \ldots \ldots \ldots 56$

Rudbeckia. . . . . . . . . . . .

$\ldots \ldots \ldots \ldots . . .56$

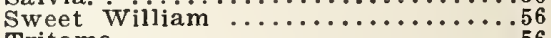

Tritoma. : .............. 56

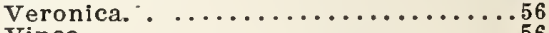

Vinca.

Violets.$\ldots \ldots \ldots \ldots \ldots \ldots \ldots \ldots \ldots 6$

Oriental Poppy .............

Gypsophila Paniculata ...........

Anchusa Dropmcre $\ldots \ldots \ldots \ldots \ldots \ldots \ldots 57$

Carnation Fireflame .............

Celosia Chrysanthemum ...........

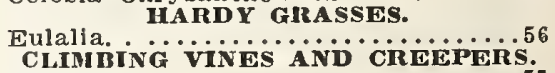

CLIMBING VINES AND CREEPERs.
Rittersweet.

Boston Ivy. . ............. . 57

Clematis. . . . . . . . . . . . . . 57

Dutchman's Pipe..$\ldots \ldots \ldots \ldots \ldots \ldots 77$

Englemann's IVy

Honeysuckle. . . . . . . . . . . . 57

Triumpet Vine $\ldots \ldots \ldots \ldots \ldots \ldots \ldots \ldots \ldots . \ldots 77$

Virginia Creeper ..................

EVERGREENS.

Evergreens, $\ldots \ldots \ldots \ldots \ldots \ldots . \ldots \ldots$

Evergreen vines.....................

Rhododendron .................... 58

All Varieties SHAE TREES.

FRÜIT TRËES.

Apples.

Apricots.

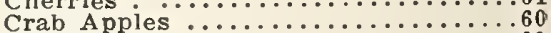

Peaches. .....................60

Plums.

Pears.

SMAít FRUTí.

Asparagus. . ...............65

Blackberries. . ....................

Currants.

Grapes.

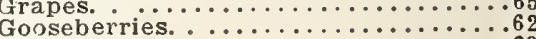

Raspberries. .............6 63

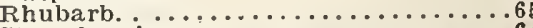

Strawberries.

DISINEECTANTS.

Paris Green Solution.

Calcium Arsenate

Bordeaux Mixture

Arsenate of Lead

Arsenate of

Dip and Disinfectant.

Black Leaf Standard Spray Püp.

Standard Spray Pum

Barrel Spray Pump

Flant Food Gruit Crop Grow

Root Crop Grower

Potato Grower

Grain Grower

Corn Grower

Bone Meal

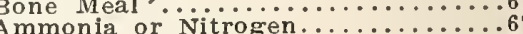

Phosphoric Acld

Potash.
Nitrate Soda. 


\section{A POCERM A Seed Inoculant
that Increases Crop Production}

Seeds of all legumes-beans, peas, clover, alfalfa, and related cropswill produce far better if inoculated with Farmogerm. In addition to the increased crops, these legumes leave in the soil a heavy deposit of nitrogen which benefits all succeeding crops. Farmers and gardeners who have used Farmogerm would not be without it.

\section{Farmogerm is the "Always Fresh" Seed Inoculant}

Because of the method of sealing the bottle-a patented stopper which admits filtered air and keeps out all impurities-Farmogerm is just as good in three or four years as when first bottled. The bacteria in Farmogerm and other inoculants of like character are living organisms, feeding on nitrogen in the air-without air, they cannot live. If tightly sealed, the bacteria gradually become weaker and weaker until they are worthless. That is why many inoculants have to be replaced before they are six months old.

\section{Farmogerm Stays Good Indefinitely}

Farmogerm keeps for years and years. Enough air seeps through the plugs to keep the bacteria in good health, yet all impurities are excluded. Other inoculants get weaker each day-Farmogerm always has its full strength. Just add water and shake the bottle and sprinkle over seeds as directed. Your crop will benefit beyond your expectations.

No other inoculant on the market is so strong and virile; no other inoculant will thoroughly inoculate as much seed. The one-acre size bottle of Farmogerm is sufficient for 15 pounds of clover, 20 pounds of alfalfa, 100 pounds of Canada field peas, 60 pounds of vetch, etc. A different culture is required for each crop. Be sure to state what crops you wish to inoculate.

\section{Be sure to use FARMOGERM to advantage on these crops:}

Canada Field Peas

Cow Peas

Garden Peas

Sweet Peas

Soy Beans

Velvet Beans

Lima Beans
Wax and String Beans
Alfalfa
Spring, Winter and
Hairy Vetch

Lima Beans

Alfalfa Hairy Vetch

\section{Peanuts}

Hubam Clover

Crimson Clover

Red Clover

Sweet Clover

Alsike

\section{Farmogerm Prices Reduced}

New methods of production have given lower prices. You cannot now afford to do without Farmogerm.

A special composite culture is prepared for peas, beans, and sweet peas, $1 / 4$-acre size only. You'll get more peas and beans, and larger sweet peas by using this. Ask for No. 5, price 50 cts.

Farmogerm prices are: 1 -acre size, $\$ 1 ; 3$-acre size, $\$ 2.50 ; 12$-acre size, $\$ 9$. Full directions accompany each bottle. 


\section{An All-the-Year Fertilizer for Garden and House Plants}

Stim-U-planT is the most effective concentrated fertilizer manufactured. It can be used easily and profitably on flowers, shrubs, vegetables, fruit and ornamental trees, and will promote more rapid growth and earlier maturity than any other grade of fertilizer. The guaranteed chemical analysis shows $11 \%$ nitrogen, $12 \%$ phosphoric acid, $15 \%$ potash.

\section{Convenient to Use}

Stim-U-plan'T comes to you in the form of small tablets, wrapped in waxed paper. A hundred can be put in a drinking-cup, yet they are so highly concentrated that each tablet contains enough food to feed a large plant from ten days to two weeks.

\section{Absolutely Odorless}

Stim-U-plan'T tablets are pleasant to handle; there is absolutely no odor nor other unpleasant feature about them. They may be used on house plants of all kinds-palms, ferms, bulbs, fuchsias, geraniums, and other indoor bloomers.

\section{Stim-U-planT Tablets}

can be used in tablet form, or dissolved in water at the rate of one tablet to the quart, or four to the gallon, which makes a liquid fertilizer of just the right strength. Order Stim-U-planT tablets with your seed and plant order. Price, 10 tablets for 15 cts., 30 for 25 cts., 100 for 75 cts., 1,000 for $\$ 3.50$.

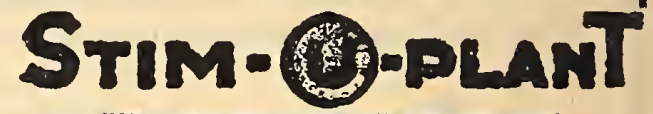
PLANT STIMULANT TABLET

\section{At Last, a Perfect Spray

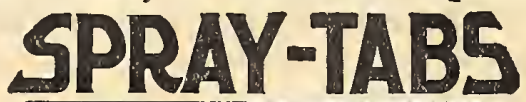 \\ BORDEAUX-ARSENATE TABLETS:}

Insecticide and Fungicide, in Tablet Form

An entirely new departure in insect control and the prevention of disease among plants. The most convenient way. No more home mixing of offensive, poisonous ingredients from bulk packages; no more improper preparation of spray solution. Spray-Tabs solve the spraying problem. The one spray for all general garden use. Dispense with bulk spray materials and use Spray-Tabs for all leaf-eating or chewing insects and the prevention of plant diseases. The making of an insecticide and fungicide in combination in tablet form marks a new era in spraying.

\section{Prevent Plant Diseases While}

\section{Fighting Insects}

Spray-Tabs combine convenience, reliability, and economy in a modern, efficient, and accurate insecticide and fungicide. The plant-grower has never before had the advantage of spray materials in tablet form. Spray-Tabs' safety and accuracy are alone sufficient recommendation. All that is needed to make an ideal spray for garden crops is to put the required number of tablets in a specific amount of water, agitate the solution and apply it to the plants. There is no opportunity to improperly make the solution.

Spray-Tabs - The New-Way Spray

Order them with your seed and plant order, that pest control may begin with garden making. Thirty tablets for 30 cts. Complete directions for every use with each package.
I want you to know how very highly I think of FARMOGERM for I have used it since 1910. I preach it whenever and wherever I can.

I wish you could have seen some golden wax beans I raised last summer after using FARMOGERM on the seed. These were planted in ground where the pods had been specked the year before. The crop this year was particularly clean, only one small speck after using your bacteria.-DR. C. R. WARD, Northome, Minn.

Please send at once Farmogerm to use on six acres of Sweet Clover sced. I got FARMOGERM last fall for Alfalfa. Have a fine stand. I left a strip where I did not use it and have nothing there, as it was all winter-killed, but where I used the FARMOGERM it stood the winter all right and this was one hard winter on everything. A. Korman, Hunt Poultry Farm, Bridgeton, N. J.

I use Stim-U-planT in liquid solution (tablets dissolved in water) for hot house plants and my plants have been in constant bloom. I am now using the table's on tomatoes, cabbages, etc., asters, petunias, dahlias. Results satisfactory.M. H. Sechler, Fort Wayne, Indiana.

Kindly send by mail another 5,000 Stim-UplanT tablets. We have used them with good results on our cantaloupes, hills yielding 7 to 10 , weighing from 3 to $4 \frac{1}{4}$ lbs. $-H$. M. Gower, Bridgeton, N. J. 
1000 Pages 1000 Pictures 1000 Ways to make money--

all in the most widely read form paper in the World

\section{Try This $\rightarrow$} big live Magazine NOW ONE YEAR, ONLY 25\&

You will be delighted with it, and wonder how such a splendid illustrated magazine can cost solittle. Sign this Coupon below, and mail AT ONCE with only 25 cents, coin or stamps. Money refunded to you any time you say so.

\section{TO THE FARM JOURNAL, Philadelphia:}

Enclosed find 25 cents for which send me THE FARM JOURNAL one year on trial. I'm not now a subscriber.

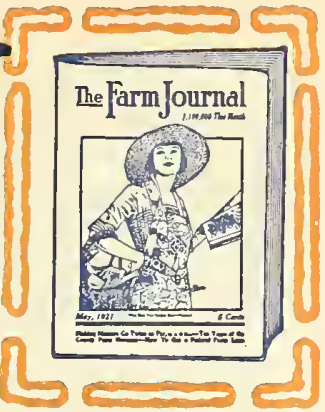

My name is.

R. F. D Box or Street...

P. O. State...

IMPORTANT: This trial Coupon must be sent direct to The Farm Journal, Philadelphia, Pa. If you live in 'Philadelphia, Canada, or a foreign country, vend 50 cents instead of 25 . to cover eztra postage. 


\section{"Mutual Benefit"}

The price of The Farm Journal is $\$ 1.00$ for 4 years; but since we believe that to read this wide-awake farm and household paper is the greatest benefit to our friends and patrons, and so indirectly to us, we have persuaded the publishers to make us this
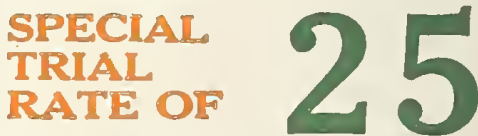

for a year's trial of the paper.

The Farm Journal is published monthly; 64 to 168 pages of new, reliable, practical, up-to-date articles and fine pictures. 45 years old, has over $5,500,000$ readers from Maine to California.

"UNLIKE ANY OTHER PAPER"

\section{Full of Gumption-Full of Sunshine}

Care of stock, horses, cows, sheep, swine; big poultry department; soil building and fertilizers; all about tractors, engines, autos; orchard, garden, vegetables; insect pests and how to control them; big Bird Club; pages for young peaple; dressmaking, fashions, patterns, embroidery; new economy recipes; farm law; beautiful poetry, Walt Mason's "poems in prose"; absorbing stories of love, adventure, and mystery.

Mail this Mutual Benefit Coupon today with twentyfive cents, silver or stamps, direct to The Farm Journal. DO NOT SEND IT TO US.

S. BRYSON AYRES SEED CO.

503 WaInut Street, Kansas City, Mo. 


\section{USEFUL INFORMATION}

LEGAL WEIGHTS AND MEASURES-Pounds per Bnshel.

\section{ARTICLES}

Apples, dried

Apples,

Bran

Barley

Beans, Casto

Buckwheat

Broom Corn Seed

Beets.

Carrots

Charcoal

Coal,

Cokn, shelled

Corn, ear

Corn Meal

Cranberries

Dried Peach

Flax Seed ......

Grass Seed, Clover

Grass Seed, Hungarian.

Grass Seed, Millet.

Grass Seed, Orchard..

Grass Seed, Timothy.

German Lupine

Hemp Seed

Hickory Nuts

Malt, Barley

Middlings, fine

Middlings, coars

Oats

Onions .....

Onions, top

Osage Orange

Parsnips

Potatoes

Potatoes, sweet

Peas,

Peas, in pod.

Quicklime

Quicklime

Salt, coärse

Salt, fine

Turnips, Rutabaga

Turnips, White

Wheat

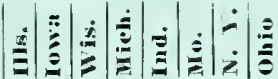

$24|24282225| 24|22| 22$

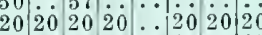

$48484848 \dot{8} 484848$

$60606060606062 / 60$

\begin{tabular}{lllllll|l|l|l}
46 & 46 & 46 & 46 & 46 & 46 & 46 & 46
\end{tabular}

5252504850524850

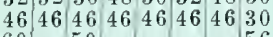

$\begin{array}{llllllll}60 & \ldots & 50 & \ldots & \ldots & 5 & \ldots & 56 \\ 55 & \ldots & 50 & \ldots & \ldots & 50 & \ldots & 50\end{array}$ $22 \dot{2} 222 \dot{2} 2 \dot{2} 222 \dot{2} \dot{8} \dot{0}$ $\begin{array}{llllllll}80 & 80 & \ldots & \ldots & \ldots & 80 & \ldots & 80 \\ 40 & 38 & \ldots & \ldots & \ldots & \ldots & \ldots & 40\end{array}$

$56 \quad 56 \dot{5} \dot{6} \dot{5} \dot{6} \dot{5} \dot{6} \dot{5} \dot{6} \dot{5} \dot{6} 56$

7070707068707068

\begin{tabular}{l|lllllllll}
48 & 48 & 48 & 50 & 50 & 50 & 50 & 50
\end{tabular}

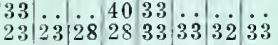

\begin{tabular}{l|l|l|ll|l|l|l}
23 & 2 & 28 & 28 & 33 & 33 & 32 & 33 \\
56 & 56 & 56 & 56 & 56 & 56 & 56 & 56
\end{tabular}

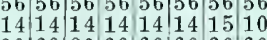
60160606060606060

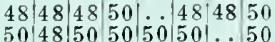

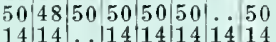
\begin{tabular}{|l|l|l|l|l|l|l|l}
14 & 14 \\
14 & 14 & 14 & 14 & 14 & 14 & 14 & 14 \\
14 & 14 & 14 & 14 & 14
\end{tabular}

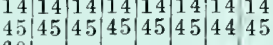
4444 44 4444 44 44 is

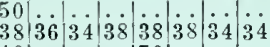
4013438383434 $401 \cdots \cdots 401$. 3232323232323232

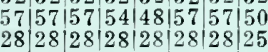

33

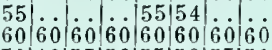
(6)

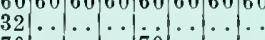
$8080|80| 80|80| 80 \mid 8 \dot{0}$

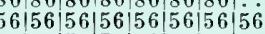

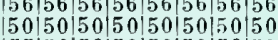
$\begin{array}{r}5050|50| 50|5050| 50 \mid 50 \\ 55150 \mid 56 \\ \hline 56\end{array}$

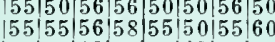
$|60| 60|60| 60|60| 60|60| 60$

Dry Mensure. 2 pints, 1 quart; 8 quarts, 1 peck; 4 pecks, 1 bushel; 36 bushels, 1 chaldron.

Liquid Measure. 4 gills; 1 pint; 2 pints. 1 quart; 4 quarts, 1 gallon; $311 / 2$ gallons, 1 barrel; 2 barrels, 1 hogshead.

Measurements of an Acre. The following will be found useful in arriving at accuracy in estimating the amount of land in different pieces of ground under cultivation: 5 yards wide by 968 yards long, contains one acre, as do also the following measurements: 10 yards wide by 484 yards long: 20 yards wide by 242 yards 10 ng: 40 yards wide by 121 yards long; 70 yards wide by $69 \frac{1}{2}$ yards long; 60 feet wide by 726 feet long; 110 feet wide by 396 feet long: 120 feet wide by 363 feet long; 220 feet wide by 198 feet long; 240 feet wide by $181 \frac{1}{2}$ feet long, and 440 feet wide by 99 feet long.

Number of Plants or Trees to the Iere at Given Distances.

\begin{tabular}{|c|c|c|c|c|}
\hline Dis. A & No. Plants. & Dis. A & part. & No. Plants. \\
\hline $12 \times 1$ & $\ldots \ldots .522,720$ & $36 \times 36$ & in... & 4,480 \\
\hline 3 & $.174,240$ & $42 \times 12$ & in.. & . 12,446 \\
\hline 12 & 43,560 & $42 \times 24$ & in. & 6,223 \\
\hline $16 \times 1$ & 392,040 & $42 \times 36$ & in. & 4.148 \\
\hline $8 \times 1$ & in..... & $48 \times 12$ & in & . 10.890 \\
\hline $8 \times 3$ & in $\ldots \ldots \ldots \ldots 116,160$ & $48 \times 18$ & in. & 7.790 \\
\hline & 29,040 & $48 \times 24$ & in. & 5,445 \\
\hline 18 & 19.360 & $48 \times 30$ & in. & 4.356 \\
\hline & 313,635 & $48 \times 36$ & in.... & 3,630 \\
\hline 20 & 15.681 & $48 \times 48$ & in.... & 2,723 \\
\hline 1 & 261,360 & $60 \times 36$ & in... & 2.901 \\
\hline 18 & 15.520 & $60 \times 48$ & in... & 2,178 \\
\hline 24 & 10.890 & $60 \times 60$ & in. & 43 \\
\hline & .209 .088 & $8 \times 1$ & ft. & 45 \\
\hline & 34.848 & $8 \times 3$ & $\mathrm{ft}$. & 1,815 \\
\hline 12 & 17,424 & $8 \times 8$ & $\mathrm{ft}$. & 680 \\
\hline & 13,068 & $10 \times 1$ & $\mathrm{ft}$. & 4,356 \\
\hline 20 & 10.454 & $10 \times 6$ & $\mathrm{ft}$. & 726 \\
\hline & 8.712 & $10 \times 10$ & $\mathrm{ft}$. & 435 \\
\hline & $\cdots \ldots \ldots$ & $12 \times 1$ & ft. & 3,630 \\
\hline & 58.080 & $12 \times 5$ & ft & 736 \\
\hline & 14.520 & $12 \times 12$ & $\mathrm{ft}$ & 302 \\
\hline & 9.6 & $16 \times 1$ & & 2,722 \\
\hline & in. & $1 f \times 16$ & $\mathrm{ft}$. & $\ldots$ \\
\hline
\end{tabular}

HETEIRENCE TABLES.

Quantity of Seed Requisite to Prodnce a Given Number of Plants and Sow an Acre.

Artichokes, 1 oz. to 500 plants

Asparagus, 1 oz. to 800 plants.

Asparagus Roots

Barley

Beans, Dwarf, $i$ pint to $100 \mathrm{ft}$ of drill

Beans, pole, 1 pint to 100 hills.

Beet, garden, $1 \mathrm{oz}$. to $100 \mathrm{ft}$. of drili.

Beet, mangel, $1 \mathrm{oz}$. to $100 \mathrm{ft}$. of drill

Broccoli, 1 oz. to 5,000 plants.

Brussels Sprouts, $1 \mathrm{oz}$. to 5,000 plants.

Buckwheat

Cabbage, 1 oz. to 3,000 plant

Carrot, $1 / 4 \mathrm{oz}$. to $100 \mathrm{ft}$. of drill.

Cauliflower, 1 oz. to 3,000 plant

Celery,

Chicory, Alsike and White Dutch

Clover, Alsike and

Clover, Crimson Trefoil

Clover, Large Red and Medium

Collards, 1 oz. to 5,000 plants

Corn, rice (shelled)

Corn, sweet, $1 / 4$ pint to $100 \mathrm{hill}$

Cress, $3 / 4$ oz. to 100 feet of drill.

Cucumber, $1 \mathrm{oz}$. to 100 hills.

Egg Plant, 1 oz. to 2,000 plants.

Endive, $1 / 4$ oz. to $100 \mathrm{ft}$. of drill.

Flax, broadcast

Garlic, bulbs, 1 1b. to $10 \mathrm{ft}$ of drili

Grass, Blue, Kentucky

Grass, Blue, English ........

Grass, Hungarian and Millet.

Grass, Mixed Lawn

Grass, Red Top, Fancy, Clean

Grass, Red Top, Chaff Seed.

Grass, Timothy

Quantity per Acre.

Grass, Orchard, Perennial Rye

Hempood Meadow

Horseradish Roots

ntity per Acre.
$\ldots \ldots 66^{\circ}$ oz.
$\ldots 1000$ to
. 7250

Kale, $1 \mathrm{oz}$. to 5,000 plants.

Kohlrabi, $1 / 8$ oz. to $100 \mathrm{ft}$ of diil

Leek, $1 / 3$ oz. to $100 \mathrm{ft}$. of drill...

Lettuce, $1 / 4 \mathrm{oz}$. to $100 \mathrm{ft}$. of drill.
Martynia, $1 \mathrm{oz}$. to $100 \mathrm{ft}$. of drill.

Maltynia, $1 \mathrm{oz}$. to $100 \mathrm{ft}$ of drill.

Melon, Musk, 1 oz. to 100 hills.

Nasturtium, 2 oz. to $100 \mathrm{ft}$. of drili.

Okra, 1 oz. to $100 \mathrm{ft}$. of drill.

Onion Seed, $1 / 3 \mathrm{oz}$. to $100 \mathrm{ft}$. of drili

Onion Seed for sets

Onion Sets, 1 quart to 40 ft. of drili

Parsnip, $1 / 4$ oz. to $100 \mathrm{ft}$. of drill.

Peas, garden, 1 pint to $100 \mathrm{ft}$ of drill.

Peas, field

Pepper, 1 oz. to 1,500 plants

Pumpkins, $1 / 3$ quart to 100 hills.

Radish. $\%$ oz. to $100 \mathrm{ft}$. of drill.

Rive

Salsify, $3 \frac{1}{4}$ oz. to $100 \mathrm{ft}$ of dribl

Summer Savory

Sunflower

Squash, Summer, 4 oz. to 100 hills

Squash, Winter, 8 oz. to 100 hills

Squash, Winter, 8 oz. to $100 \mathrm{~h}$
Tomato, 1 oz. to 4,500 plants.

Tomato, $1 \mathrm{oz}$. to 4,500 plants.

Tobacco, $1 \mathrm{oz}$. to 5,000 plants
Turnip, $1 \mathrm{oz}$ to $250 \mathrm{ft}$. of drill

Turnip,
Vetches

Average Time Required for Garden seeds to Germinate.

Beans ....
Beets ....
Cabbage .
Carrot...
Cauliflower
Celery....
Coln ....
Encumber.
Endive...

\begin{tabular}{|c|c|}
\hline Days. & \\
\hline 5 to 10 & 10 \\
\hline 7 to 10 & 10 \\
\hline 5 to 10 & 10 \\
\hline$?$ to 18 & 18 \\
\hline 5 to 10 & 10 \\
\hline 0 to 20 & 20 \\
\hline 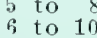 & \\
\hline & \\
\hline
\end{tabular}

Lettuce.

Pea.

Parsnip

Pepper

Salsify

Endive

Trmato

Thue lientired for Haturity of Different Garden Crops Reckonad from the bay of sowing the seed.

Beans, String.....45 Days. Melon. Musk ....120 Days.

Beans, String....45 to 65 Melon. Musk ....120 to 140

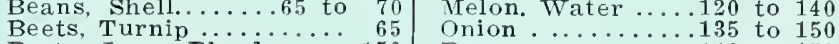

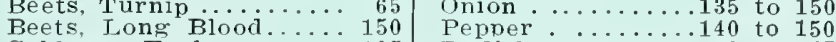

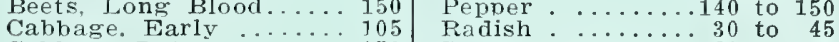

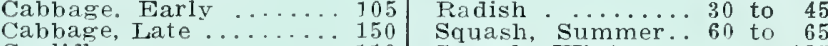

Cauliflower

Egroplant

150 Squash, Summer
110 Squash. Winter

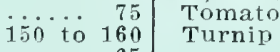



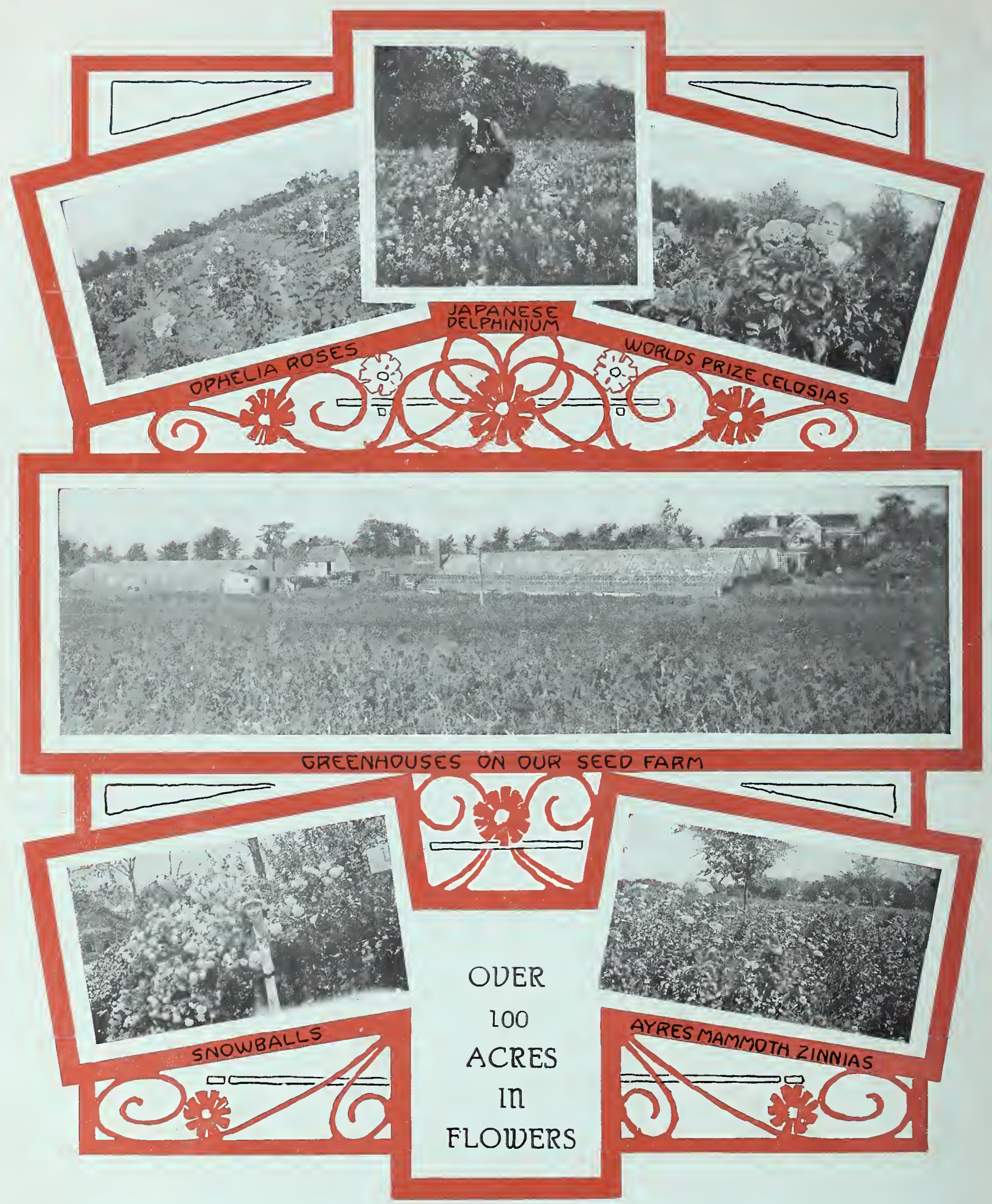

THE above illustrations and those on front cover are from photographs taken at the BRYSON AYRES SEED CO.'S Sunny Slope Seed Farms and Nurseries located six miles east of Kansas City, Mo., and one mile south of Independence, Mo., and the Blue Ridge Farm at 39th and Blue Ridge Boulevard.

VISITORS ALWAYS WELCOME 